\title{
El relato testimonial en la literatura argentina de fin de siglo
}

Autora aspirante: Lic. Adriana L. Goicochea Director de tesis: Dr. José Amícola 


\section{ÍNDICE}

- Presentación

- Introducción

- Capítulo I: El relato testimonial: Aproximaciones teóricas

I - La crítica del testimonio hoy: ¿Polémica o clausura?.

II - Del relato testimonial: Literatura y discurso social

III - El testimonio frente a los estudios literarios

1. Acerca de la literaturidad

2. Acerca de la ficcionalidad

3. Acerca del género

- Testimonio y novela

- Nueva Novela Histórica

- Testimonio y autobiografía

IV - El testimonio en la Argentina

1. Sus antecedentes

2. El fin de siglo: Memoria de la violencia

3. Una propuesta de lectura

- Capítulo II: Lecturas del pasado en dos obras de Miguel Bonasso

I - Recuerdo de la muerte

1. Lo testimonial

2. Discurso y representación

3. Novela y política: una lectura

II - La memoria en donde ardía

1. La novela, entre lo autobiográfico y lo testimonial

2. Relato testimonial y sujeto narrativo.

3. El lector implícito

4. Narrativa metaficcional

Capítulo III: Un relato contra el olvido: José, de Matilde Herrera

I - Un texto particular

II - Una "historia de vida"

III - Memoria del pasado 
- Capítulo IV: Huellas del pasado en el mundo ficcional de El fin de la historia, de Liliana Heker

I - Voces y perspectivas

II - Los tiempos del relato

III -Testimonio y producción de sentido

IV - Mundo ficcional y representación del pasado

Capítulo V: Memoria y ficción en la Argentina de fin de siglo

I - Diálogo interdiscursivo

II - El campo cultural de fin de siglo

- Capítulo VI: A modo de síntesis

- Anexo: Visita a Duke University

- Bibliografía 


\section{Introducción}

La hipótesis que sostendré en este trabajo es que el relato testimonial es intertextual, que recupera el discurso factual y deconstruye los sentidos institucionalizados produciendo un nuevo conocimiento. Con esos presupuestos, afirmo que el sujeto se configura en la relación intersubjetiva a la que abre el relato a partir de la memoria materializada en la escritura.

Estas ideas se apoyan sobre la lectura del sistema literario de la Argentina de fin de siglo, operación que me permite recuperar ciertos textos que considero pertenecientes a una clase discursiva a la que he identificado como "relato testimonial".

El corpus está constituido provisoriamente por un conjunto de textos que han sido seleccionados con los siguientes criterios:

$\left.1^{\circ}\right)$ Presentan una diferencia de grado en cuanto a la ubicación del relato testimonial en la discusión teórica de lo ficcional-no ficcional. Esta gradación permite localizar en un extremo textos como Nunca más (Informe de la Comisión Nacional sobre la Desaparición de Personas); El flaco perdón de Dios, de Juan Gelman y Mara La Madrid; La otra historia, de Roberto Perdía; José, de Matilde Herrera; y en el otro extremo, El fin de la historia, de Liliana Heker; La ciudad ausente, de Ricardo Piglia; Cola de lagartija y Novela negra con argentinos, de Luisa Valenzuela.

Dentro del marco que diseñan estos textos ubico obras que entiendo representan un crescendo hacia la actualización de la convención de ficcionalidad. Ellas son: Recuerdo de la muerte y La memoria en donde ardía, de Miguel Bonasso, y Herederos del silencio, de Gabriela Cerrutti.

$2^{\circ}$ ) Este espectro de textos está organizado también en torno de un núcleo temático: la memoria de la violencia de la década del setenta en la Argentina.

$3^{\circ}$ ) La configuración de este campo de trabajo está sustentada sobre la idea de que existe una subrayada fluidez entre los textos, marcada por un imperativo: la necesidad de articularlos en un diálogo para que el testimonio 
trascienda lo privado y subjetivo y aporte nuevos sentidos que abarquen lo colectivo y social.

$4^{\circ}$ ) Otro aspecto sustantivo, y sobre el cual argumentaré, es que existen instituciones que en su relación con la literatura justifican la producción, circulación y recepción de estos textos, especialmente el periodismo. Todo ello tiene un principio históricamente dado y conflictivo en la literatura argentina: los vínculos entre literatura y política.

Los enunciados precedentes se apoyan sobre asunciones teóricas que explicitaré en el apartado siguiente. 
Capítulo I

El relato testimonial:

Aproximaciones teóricas 


\section{I - La crítica del testimonio hoy: ¿Polémica o clausura?}

La relevancia que ha adquirido en las últimas décadas el relato testimonial, en tanto producción de una práctica discursiva como por los estudios críticos que se han ocupado de él, constituye un incentivo cierto para esta investigación.

El interés de los debates académicos puede ser atribuido a diversos factores, entre los que podemos mencionar como significativos la importancia política del mundo representado, el debate que abre en relación con la literariedad y la incorporación de un nuevo canon.

Sin duda, el testimonio es para América Latina una modalidad discursiva que ha disuelto las fronteras entre la literatura y la información, instalando la discusión en torno de los géneros y de la función política de la literatura, sin olvidar un tema central como es el problema de la referencialidad. Sin embargo, la opinión de John Beverly: "El momento del testimonio ha pasado", con que cierra el capítulo final del libro The Real Thing, el último también que se ha publicado sobre el tema, instala una nueva perspectiva en el abordaje que la crítica realiza del testimonio.

The Real Thing plantea un profundo debate sobre el tópico que mantuvo vivo el interés de los críticos y de la reflexión teórica desde la década del setenta e intenta la clausura de la discusión sobre el testimonio, aunque no así de su producción. La lectura de esta obra obliga a realizar una revisión de esa reflexión. Así es como creo posible identificar tres grandes momentos, materializados en publicaciones de amplia difusión, que sintetizan las tendencias de cada década:

-1986: Literatura y Testimonio. Varios autores. Institute for the Study of Ideologies and Literature, Minnessotta, Estados Unidos de Norteamérica.

-1992: Revista de Crítica Literaria Latinoamericana, Año XVIII, N 36, dedicado exclusivamente al testimonio. Latinoamericana Editores, Lima, Perú.

-1992: En otras palabras, otras historias, compilación de Hugo Achugar, publicada por la Universidad de la República, Montevideo, República Oriental del Uruguay. 
- 1996: The Real Thing. Varios autores. Duke University Press, Durham, Estados Unidos de Norteamérica.

A mi criterio, los ejes de discusión plasmados en estas obras se desarrollan en torno de las siguientes cuestiones:

* Las notas propias de esta práctica discursiva, que constituyen su especificidad.

* Los problemas teóricos que plantea y que podrían sintetizarse en dos aspectos: la relación testimonio-literatura y testimonio-ficción, que conducen a la pregunta acerca de su "efecto" pragmático.

* Las tendencias del relato testimonial que surgen del análisis del universo simbólico y discursivo, como discurso testimonial por un lado y novela testimonial por otro.

Considero que es oportuno detenerme aquí para explicitar los aportes sustanciales que se produjeron en cada uno de los momentos que he mencionado.

Durante la década del ochenta la reflexión teórica sobre el testimonio se localiza en los trabajos de Renato Prada Oropeza, Héctor García Cavallari, Víctor Casaus y Miguel Barnet, fundamentalmente. Algunos de estos críticos proponen una definición del testimonio destacando su condición de género situado al margen del discurso literario, espacio desde el cual encarna las posibilidades de lucha de los sectores marginales que comparten el sufrimiento social.

Eliana Rivero acepta, en esta instancia de la meditación crítica (1984), que se trata de una "huella de lo real". En un trabajo posterior, de 1987, afirma la dificultad para deslindar testimonio y literatura en virtud de que la situación comunicativa de recepción es imaginaria, pero el referente es percibido como real, aunque siempre a partir de una convención de veracidad. Su perspectiva focaliza la cuestión estética y propone localizar la especificidad del testimonio en la índole del narrador testimoniante.

René Jara y Jorge Narváez consideran al testimonio como "narración de urgencia" o "discurso necesario", respectivamente. Se refuerza de este modo la peculiaridad del testimonio latinoamericano vinculado a una identidad o linaje de "discursos de resistencia". Narváez, además, afirma que el estatuto de estos 
textos sin estatuto anula la contradicción ficción-no ficción entendida como mentira-verdad y considera que de ese modo estos textos documentos instauran un espacio de lo real-maravilloso.

El concepto más relevante en cuanto a las fronteras del género es el de novela-testimonio de Miguel Barnet, quien afirma que es una "variante del relato" que se propone un desentrañamiento de la realidad tomando los hechos principales, describiéndolos por boca de uno de sus protagonistas más idóneos, con lo que se suprime el yo del escritor. Según Barnet, el gestor de la novela-testimonio tiene así la misión de revelar "la otra historia", por eso debe investigar. Lo estético está subordinado a lo funcional y práctico. En la novelatestimonio se articula la memoria colectiva, el nosotros y no el yo.

La reflexión crítica de la década del ochenta trasciende la búsqueda de las raíces del testimonio para ocuparse de sus particularidades y los alcances del género. De este modo se inicia un camino de meditación teórica que revierte lo que Elzbieta Sklodowska considera la "falacia genealógica" que se ha cometido a partir de la definición difundida por Casa de las Américas a la que le cuestiona fundamentalmente haber propuesto reflexiones sobre el testimonio sin determinar sus características propias. ${ }^{1}$

De la compilación de Hugo Achugar, En otras palabras, otras historias, publicada en 1992 y que según señala en el prólogo reúne las investigaciones iniciadas en 1988, considero importante destacar las siguientes hipótesis:

* El compilador cita el concepto de Michel Foucault en cuanto a que la lucha por el discurso es la lucha por el poder y ratifica las afirmaciones de René Jara en la reflexión crítica previa: la especificidad del discurso testimonial no se determina en relación con su referencialidad sino por su función pragmática.

* El discurso testimonial tiene una fuerte relación con la fuente de sentido, que apunta a un sujeto enunciador colectivo. De este modo es un acto de habla ejemplar que desarticula el discurso del poder. En el texto se cita a la pensadora hindú Gayatri Spivak, quien en su ensayo se pregunta "Can the subaltern speak?" y concluye con una respuesta negativa. Achugar sostiene que "a pesar de esa suerte de imposibilidad discursiva que la situación subalterna impone en el otro lado del ámbito del poder está testaruda e insistente la voz subalterna contando su historia otra, su otra palabra". ${ }^{2}$ 
* Para Achugar el discurso testimonial es configurado por y para un interlocutor ilustrado tanto política como estéticamente, por lo que se registran marcas discursivas propias de ese estrato. Identifica como tales: la presencia de estrategias discursivas y narrativas vigentes en la tradición canónica; la eliminación de la distancia entre escritura y praxis y la constitución de un sujeto social que es solidario pero diferente del pueblo iletrado.

Finalmente, Achugar produce una interesante síntesis de estas hipótesis planteando que los rasgos distintivos del testimonio, en tanto espacio discursivo ideológico y retórico, se encuentran, en el nivel del enunciado, en el registro de la voz del Otro y en el efecto de oralidad/verdad, y en el nivel pragmático, por su función ejemplarizante y denunciadora y por la autorización letrada que permite el ingreso al espacio letrado de la esfera pública.

Estas características marcan diferencias entre el testimonio y la autobiografía, considerada como discurso acerca de la "vida privada", y problematizan su relación con la literatura. Al respecto, Achugar sostiene que la autobiografía circula como literatura pero no se identifica como ficción, sino que se define como elaboración ideológico formal. El testimonio, en tanto, escapa a este campo y aparece en espacios ajenos al literario, tales como el jurídico y el periodístico.

Como he anticipado, un momento trascendente para la reflexión teórica para el testimonio está representado en la década del noventa por la Revista de Crítica Literaria Latinoamericana, que en su número dedicado a este género explicita los objetivos de los estudios críticos de la época: preservar o profundizar el poder estético, ético, epistemológico especial del testimonio y cuestionar algunos de sus mecanismos de producción y recepción.

John Beverly, autor de la Introducción, destaca tres problemas en torno de los cuales se desarrollan los ensayos que conforman ese volumen:

* La relación del testimonio con la institución literaria.

* La cuestión de la verdad del testimonio.

* La relación testimonio y política.

En cuanto al primer aspecto, la relación testimonio-literatura, se presentan dos líneas de discusión teórica. 
Para algunos se trata de una forma de literatura que recupera la "voz del subalterno" y se constituye en un discurso resistente al canon, implica una desnaturalización de los modelos consagrados. En esta perspectiva de análisis, John Beverly considera que "la incorporación del testimonio a la torre de marfil del humanismo académico-literario puede esconder a veces una lucha a muerte sobre el poder de la representación" y también que "la tensión entre el testimonio y la literatura culta es una tensión no sólo históricamente determinada sino necesaria en el mundo actual; de ahí que debemos estar en guardia contra su domesticación académica". 3

Existe otra línea de discusión, más escéptica, que lo considera "otra" forma de literatura sancionada por el poder y la autoridad académica, pues diluye la capacidad del testimonio para reconstruir la verdad de lo subalterno. Se relativiza de este modo su poder estético e ideológico especial.

Frente a estas dos corrientes se afirma la posición de los teóricos que participan del ejemplar de la Revista mencionada y que Beverly sintetiza cuando dice que "entre las muchas lecciones del testimonio debe estar una que señala que tenemos que aprender a leer no sólo a 'contrapelo' como propone la crítica deconstructivista sino contra la literatura misma". ${ }^{4}$

En su ensayo, Antonio Vera León analiza el rol del transcriptor en el texto testimonial y plantea que el desencuentro de dos sujetos, el narrador oral y el transcriptor, constituye el régimen de la escritura testimonial. Desde esta perspectiva el testimonio pone en tensión el paradigma de la escritura ficcional y construye su propio estatuto literario y político, mientras subyace la compleja relación entre la realidad empírica y su representación, entre testimonio y verdad.

George Yudice, por su parte, disuelve la dicotomía verdad-ficción en la constitución del testimonio y sostiene que "su modus operandi es la construcción comunicativa de una praxis solidaria y emancipativa". Se aproxima, entonces, a la tercera cuestión problemática: la naturaleza política del testimonio, que según John Beverly se funda en una estética. En este sentido, creo que Yudice completa el concepto afirmando que "la estética de la concientización", como praxis, es el marco epistemológico propio del testimonio 
y éste lo convierte en una práctica cultural que apunta a subvertir el orden de las cosas que corresponde a la modernidad.

Esta exposición le permite a Yudice establecer una diferencia entre el testimonio "para representar", como es el de Cuba, y el centroamericano que surge como lucha por la sobrevivencia. A su vez, Achugar también señala la dicotomía entre testimonios planteados como proyectos discursivos fomentados desde el poder y los desarrollados al margen de la institución, respectivamente. Estos últimos, en la concepción de Beverly y Mark Zimmerman, producen un cambio de paradigma narrativo. En sus estudios más recientes, ambos autores adjudican legitimidad al testimonio producido desde el subalterno.

Sin embargo, estos críticos han señalado la pérdida del sentido esencial del testimonio. Para Beverly, se produce cuando ingresa al taller de un escritor. Yudice, por su parte, señala que el impulso popular se desdibuja cuando el establishment político usa al testimonio como estrategia de concientización; el testimonio no debe perpetuar un orden existente sino problematizarlo.

Desde el momento de su canonización en los setenta, por el Concurso Casa de las Américas, el testimonio se incorporó al sistema literario latinoamericano y también a la reflexión crítica. Esta instancia ya marcó la pérdida de su legitimidad en términos de la función política que se le ha asignado hasta aquí.

Esta reseña de las cuestiones que ha planteado la producción y el estudio del testimonio es el marco a partir del cual se produce la discusión en la obra The Real Thing, según se ha anticipado.

Me interesa particularmente detenerme en la problemática de la relación testimonio-literatura. En este sentido, la posición de John Beverly es mantener al testimonio fuera del campo literario por su efecto ético-político, por sus posibilidades de solidaridad. Beverly considera que subsumirlo en la categoría de ficcionalidad literaria es constituirlo simplemente en una forma de literatura y restarle su poder sobre el lector. Asimismo, polemiza con Barbara Foley ${ }^{6}$, quien al establecer una diferencia de grado entre los relatos documentales le asigna al testimonio un grado de ficcionalidad. 
Entre ambos críticos existe, entiendo, una diferencia teórica sustancial que implica la relación literariedad-ficcionalidad, por un lado, y abarca una teoría del relato, por otro. Beverly identifica ambos conceptos y resta valor pragmático a la ficción. Subyace en su posición una razón ideológica y una fuerte voluntad política de preservar al testimonio para que no pierda su condición de discurso problematizador del poder. Por el contrario, Foley diferencia literatura y ficción y sostiene que existe en los relatos una diferencia de grado en cuanto a la ficcionalidad, pero que en tanto narración también es construcción y creación. La estética del testimonio es representación y también creación del mundo representado.

Para Beverly el testimonio pone en cuestión la institución actualmente existente de la literatura, entendida como aparato ideológico de alienación y dominación, por lo que a su juicio se presenta como una forma de discurso extraliterario o antiliterario. Este criterio está muy lejos de la propuesta barnetiana de los setenta, de la representación como transparencia. Coherente con ello, se establece una clara distinción entre testimonio y novela testimonial. Con el testimonio surge un sujeto proletario, popular y democrático, mientras que la novela se relaciona con el surgimiento de la burguesía.

Beverly se pregunta si el testimonio es una nueva forma de literatura o una forma alternativa del canon, para responder que se trata de un emergente de la cultura popular-democrática que ya no se basa en las instituciones del humanismo y la literatura. El subalterno no puede ser representado en la literatura o en la universidad, pues ambas son instituciones que crean y mantienen su condición de subalternidad. En su artículo final, que da nombre al libro, Beverly revisa la función del testimonio en los sesenta y los setenta y su vinculación con las redes de solidaridad internacional que organizaron los movimientos revolucionarios por los derechos humanos; tal vez su afirmación más significativa es que el testimonio, separado de ese contexto, perdió su poder estético-ideológico y se convirtió en una forma más del costumbrismo. El autor clausura así el debate sobre el tema que se viene realizando desde la década del setenta, pero reconoce la vigencia del testimonio como práctica discursiva propia de la realidad de América Latina. 
También es interesante otro ensayo de la obra The Real Thing que a mi juicio nuclea la posición de diferentes teóricos para profundizar el debate, "The aura of testimonio", de Alberto Moreiras.

Moreiras plantea que lo que hace interesante la lectura del testimonio es que implica un abandono de lo literario, pues le posibilita al lector entrar en una región donde lo literario se abre a algo más que no es lo real. Ése es su reclamo político prominente. La distancia entre enunciador-receptor, la paradójica relación nosotros-otro, da lugar a la solidaridad, punto en el que ha seguido las reflexiones de Beverly y Yudice. Sin embargo, su propuesta es que la solidaridad es un fenómeno de orden no-representacional que reclama una delimitación de su status epistemológico de conocimiento genuino del otro. Como consecuencia, la solidaridad, que es el aspecto esencial que diferencia al texto testimonial del literario, no puede constituirse en una poética de la solidaridad cuando es su función producir una ruptura con la poética. En otras palabras, como "aesthetic fix" (concepto de Yudice), el testimonio no produce solidaridad, sino solamente una poética de la solidaridad. Así es como en manos de la crítica el testimonio pierde su fuerza extraliteraria, se disuelve su efecto político.

Otra cuestión presentada por Moreiras que reviste interés, es su perspectiva de análisis de los estudios críticos latinoamericanos.

En primera instancia señala que la reflexión sobre el testimonio no depende sólo de factores como la introducción de la voz del subalterno en el discurso disciplinario, como la posibilidad de articular a través de su discurso una práctica política de solidaridad o como la reactivación de la discusión acerca de lo que constituye la literatura. Identifica, sí, dos factores determinantes para que se fortalezca la crítica sobre el testimonio: por un lado pide una conceptualización que Moreiras considera necesaria para la identidad política latinoamericana, en tanto marca la irrupción de un sujeto de enunciación no tradicional; por otro lado, el testimonio le permite a la crítica literaria mantenerse al margen del colapso de la literatura "alta". Desde esta posición la reflexión sobre el testimonio, lejos de llegar a un agotamiento, reafirma su vigencia y necesidad. 
El planteo de Moreiras alcanza implicaciones más profundas cuando afirma que lo que importa verdaderamente es determinar si la atracción por el testimonio que demuestra la crítica latinoamericana está en función del latinoamericanismo como instrumento o bien como obstáculo para la dominación colonial. Su propuesta es que la crítica del testimonio debe seguir el llamado de su objeto como un aparato postliterario (en términos de Beverly) o postmodernista, como disciplina política.

Esta síntesis de los momentos esenciales de la reflexión sobre el testimonio tiene un eje conductor, la relación testimonio-literatura en el debate de la crítica, y por eso corre el riesgo de presentar una lectura parcial de las obras mencionadas. Sin embargo, la selección del problema central que estoy presentando aquí fue inducida por mi conversación con John Beverly, previa a mi lectura del libro The Real Thing. Descubrí entonces justamente que polemizaba con Barbara Foley, con cuya propuesta teórica coincido y por ende sostiene mi investigación.

Dejo constancia, por un lado, de que existe un fundamento que sustenta mi elección, la teoría del relato; por otra parte, destaco la fuerte intencionalidad política que conduce a Beverly a oponer testimonio y literatura: la de preservar su efecto sobre la sociedad y el campo de lectura y producción. (Ver Anexo).

He tomado como punto de partida el concepto de que el relato es el rasgo unificador de todos los textos que conforman el corpus de este trabajo. En la concepción de Paul Ricoeur es una forma de conocimiento, una manera de hacer inteligible el mundo. Así, los acontecimientos tienen significación en la medida en que ingresan en la organización simbólica del relato y éste es aceptado en un determinado momento histórico-cultural.

La narrativa histórica y la ficcional tienen igual categoría en tanto son discursos simbólicos. Existe en ambas una configuración de los acontecimientos, una trama, un sujeto que busca dotar de sentido al mundo. Narrativa ficcional y no ficcional no se oponen sino que se complementan. Todo relato es representación y creación.

Mi afirmación sobre la existencia de un campo de ficción en el que los relatos que constituyen su entramado mantienen entre sí una diferencia de grado, encubre un problema teórico: el de la ficción. Aquí se presenta como 
una cualidad sujeta a variación histórica. El acto de proponer y aceptar el contrato ficcional es un acto político sustentado en un pacto de lectura.

En este marco conceptual la distinción ficcional-no ficcional está atravesada por la problematización de dos nociones: la de referente y la de verdad. Ambas se disuelven en los postulados de la semántica de la ficción (Lumezil Dolezel, 1989) y la hermenéutica de Paul Ricoeur, corrientes teóricas que desarrollaré en el apartado siguiente.

Una de las aserciones teóricas que a mi criterio resulta relevante para explicar mis consideraciones acerca del relato testimonial es que la semántica de la ficción busca una explicación de los "mundos posibles" por su relación con el "mundo actual". Los individuos ficcionales no pueden ser identificados como reales del mismo nombre. En tal sentido, lo posible supera a lo real y se constituye como un mundo alternativo. Como consecuencia, cae toda discusión sobre la "verdad" como noción superpuesta a realidad o "referente" y se recupera la noción de "verdad posible" en un universo semántico. El mundo de la ficción es dual, pues en él coexisten un universo actual y un universo secundario. Se accede al mundo posible desde el mundo real que lo hace creíble, pero por canales semióticos. Existe un espacio simbólico de significación compartido por el lector y el escritor, y en él hay huellas de lo real que potencian la creencia y afianzan el pacto de lectura. El sentido se halla en el encuentro entre el mundo del texto y el mundo del lector.

Otro de los principios teóricos que he considerado importante para el estudio del testimonio es que el efecto de la ficción sobre la realidad es discursivo, porque se da sobre otros universos simbólicos. Desde la ficción se produce una interpretación del mundo actual, de modo que, inscripta en otras ficciones, modifica el horizonte simbólico de la cultura.

Por otra parte, y volviendo sobre la posición de John Beverly que he enunciado antes, destaco que el objeto de estudio de la academia norteamericana ha sido siempre los relatos testimoniales latinoamericanos (Cuba, Centroamérica) o chicanos. En tanto, el corpus de mi trabajo, delimitado a la producción de la Argentina, reconoce en el campo de circulación textual de este fin de siglo al testimonio como lectura literaria aunque haya cumplido otras funciones, por ejemplo, en el campo jurídico, como es el caso de Nunca más. 
Otros textos que constituyen el corpus de mi investigación pertenecen al género novela y responden por ello a las características que enunciara Mijail Bajtin. $^{7}$ Este autor reconoce a la novela como un género no cristalizado, producido y alimentado por la época moderna y por tanto profundamente emparentado con ella. Sus rasgos esenciales son el plurilingüismo, la estetización y parodia de otros géneros, la dialogización; la palabra del autor se representa y está en el mismo plano que la del personaje. En síntesis, dialogismo, polifonía e intertextualidad son los caracteres propios del género, que pueden encontrarse en las obras que analizaré.

\section{II - Del relato testimonial: Literatura y discurso social}

Las obras seleccionadas como corpus de trabajo son relatos testimoniales, en tanto reúnen los rasgos propios de este género. Entre ellos enunciaré dos: el carácter narrativo y la interdiscursividad, a los que me referiré seguidamente.

El carácter narrativo impone algunas características que se manifiestan en el montaje y en el contenido. En cuanto al montaje del relato, considerado un elemento constitutivo de la literariedad y un procedimiento de unificación y expansión, se caracteriza por la subjetivación y la intertextualidad.

Sin duda, una de las particularidades del relato testimonial es que ficcionaliza personajes provenientes de lo real. El narrador actúa como testigo, actor y juez de lo narrado, pero su voz proviene de la experiencia y de la historia y sobrepasa lo individual para ser representativa de un grupo con el que se identifica como sujeto de la enunciación. Así es como produce un enunciado que es su verdad, su versión de los hechos.

Por lo tanto, es la presencia del sujeto y su individualización o compromiso con el relato lo que determina las diferencias del relato testimonial con el relato histórico o periodístico. Es, en efecto, un elemento fundante para establecer la diferencia entre relato ficcional y no ficcional y ha facilitado, además, una delimitación entre relatos testimoniales en los que existe una coincidencia entre el autor y el narrador (Nunca más, por ejemplo) y otros, en 
los que se marca una no-correferencialidad entre ambos roles (Es el caso de El fin de la historia).

Otro aspecto particular a considerar, como dije anteriormente, es el de la intertextualidad. El testimonio es narración de un acontecimiento y por consiguiente transporta los hechos al plano discursivo, pero también opera con otros discursos para dar otra versión de lo narrado por la historia o el periodismo. Es justamente la citación el procedimiento propio de un modo de narrar que plantea el sentido como selección y construcción. En esta instancia el relato apela a la competencia del lector, reclama una comprensión ${ }^{8}$. El procedimiento de lectura recontextualiza los discursos citados en busca de la producción de sentidos.

En síntesis, esta estructura narrativa, como he dicho antes, implica un montaje, lo que para Michel Glowinski ${ }^{9}$ es un método de novelización y produce el desarrollo de la forma novelística en varios tipos discursivos. Si nos atenemos a este concepto, el relato testimonial ingresa al campo de la literatura por su propia composición textual.

Por otra parte, es significativa la importancia del contenido del relato testimonial a la hora de determinar sus particularidades. Si hay acuerdo en que el relato testimonial refiere historias individuales no sujetas a una tesis general, puede afirmarse también que son representativas para un grupo. Ahora bien, en los textos que conforman nuestro corpus no se trata de recuperar la voz de los marginados, como en la literatura latinoamericana, sino de las víctimas. Se trata en este caso de los expulsados de su condición de sujetos y de ciudadanos, y de su núcleo familiar centrado en la madre, la abuela y los hijos. Es por eso que estos testimonios constituyen una denuncia de la relación opresor-oprimido, sujeto-objeto, a partir de una actitud revisionista respecto del poder centralizado en la violencia del Estado.

Otro elemento de interés son los detalles y la singularización que ahondan en la vida privada y constituyen un recurso para otorgarle mayor credibilidad. El relato testimonial se instala no como una desviación del discurso "serio", sino como una alternativa. Dice lo que otros discursos ("serios") han silenciado o han dicho de otro modo. De allí su valor de praxis inmediata, su función política. 
Como afirma Sklodowska, existe un pacto de veridicción. La verdad no está sólo en la voz del narrador, sino que el ethos del testigo se conjuga con el del receptor. La función política es el nexo entre el autor y el receptor, ambos tienen una condición previa: una misma preocupación histórica y una posición crítica frente a los acontecimientos narrados. El relato testimonial no puede ser neutral; tampoco puede su audiencia permanecer indiferente.

Según anticipara al iniciar este apartado, otro rasgo propio del relato testimonial es la interdiscursividad, que actúa como principio organizador del campo y que señala un marco de lectura. El relato testimonial reclama una comprensión que implica un procedimiento de lectura: ponerlo en diálogo, revelar las relaciones interdependientes con otros discursos.

Además, la interdiscursividad le otorga al relato testimonial un rol fundamental en relación con la "literaturidad"10. Su incorporación al sistema literario promueve una modificación de la norma, una ampliación del campo, al que introduce otros géneros provenientes de la cultura de masas. La noción de interdiscursividad supera a la de intertextualidad, propia del texto visto en su clausura, pues tiene aún alcances más amplios: el sentido se despliega en otros discursos del terreno social, se construye en la relación intersubjetiva.

La producción literaria y su valoración crítica inauguran una nueva noción: la de campo de ficción, en el que se organiza un espectro de textos que instalan la discusión sobre la ficcionalidad. El lugar del testimonio en el campo de la literatura y en el campo de la ficción es un motivo de reflexión teórica que conduce a realizar algunas consideraciones acerca del género.

\section{III - El testimonio frente a los estudios literarios}

La aparición del testimonio ha generado una profunda reflexión en el campo de la teoría literaria, pues problematiza tres importantes núcleos de discusión para esta disciplina: la "literaturidad" por un lado; sus relaciones con el problema de la ficcionalidad, por otro; y afecta también a la cuestión del género.

Me interesa hacer una revisión del desarrollo que estos problemas han tenido, ya que se imponen como objeto primordial de los estudios literarios en 
distintos momentos y paradigmas, para luego centrarme en el lugar que ocupa el relato testimonial en esta esfera de discusión teórica.

\section{Acerca de la literaturidad}

Sin duda, la pregunta sobre qué es la literatura está en la base de la teoría literaria. Sin embargo, no se ha llegado a una definición satisfactoria, aunque sí es posible encontrar diversas respuestas, dadas desde los enfoques teóricos.

Así es como las teorías de la especificidad buscan propiedades esenciales inherentes a las obras que denominamos literarias y que las distinguen de otras prácticas, mientras que los enfoques teóricos institucionales presentan una perspectiva histórica y llegan a la conclusión de que la literatura es aquello que una sociedad determinada define como tal en un tiempo y espacio.

Sin embargo, las discusiones más productivas en el campo del análisis teórico se reparten según dos criterios: por una parte, la literaturidad se define en términos de una relación con una realidad supuesta como imitación de los actos de lenguaje cotidiano. Por otra parte, apunta a determinadas propiedades del lenguaje.

Es importante precisar que la pregunta acerca de la literaturidad se planteó con la fundación de la teoría literaria y con el único objeto de encontrar la especificidad para promover métodos de análisis que permitieran avanzar en la comprensión de este objeto. Así, pues, fueron los formalistas rusos los que formulan los grandes principios del debate sobre el problema que nos ocupa.

Para los formalistas, la literaturidad posee tres rasgos fundamentales: los procedimientos del propio lenguaje; la relación del texto con las convenciones y con otros textos; la perspectiva de comparación del texto y los materiales utilizados.

La famosa definición por parte de Víctor Sklovski del arte como un extrañamiento (ostranenie) reviste gran importancia teórica. En primer lugar sirve como un modo de distinguir el sistema literario de otros sistemas extrínsecos; en segundo lugar permite una nueva concepción de la historia 
literaria. La evolución literaria es entendida como una ruptura con los cánones dominantes, pero también implica la canonización de algo nuevo.

Otra dimensión del concepto de ostranenie es la distinción entre poesía y prosa, que sirve para atraer la atención sobre las estructuras, entendidas como estrategias verbales esenciales de la obra literaria.

El salto cualitativo que introduce este autor se halla no en la génesis de los textos sino en cómo éstos funcionan, en la manera en que determina el rol que le cabe al procedimiento literario y en su convicción de que la literatura es construcción. $^{11}$

Éste es el punto de partida que desencadena una paulatina acentuación de ideas clave que van a dar forma a la noción de procedimiento y de procedimiento a la noción de función.

La "desfamiliarización" del lenguaje que produce la percepción de la lengua poética puede obtenerse mediante diferentes recursos en el plano del significante, en el caso de la poesía, y mediante las estructuras que producen efecto de clausura, en la prosa. Hay, sin embargo, una reserva que hacer cuando limitamos el efecto de literaturidad a la presencia de un repertorio lingüístico, pues estos procedimientos pueden encontrarse en textos no literarios.

Jakobson indica una vía de reflexión en su diferenciación de las seis funciones del lenguaje cuando define a la función poética como aquella que focaliza el mensaje en cuanto tal. Esta definición conlleva la demostración de una tendencia: la emancipación de la referencialidad. Mientras que para Jakobson en la lengua "práctica" la función predominante será la comunicatividad, otra cosa sucederá en el ámbito de la lengua poética. La poesía será un enunciado cuyo posicionamiento está puesto en la expresión misma, en lo que se llama su función estética. La obra literaria se define entonces porque en ella la literariedad es la dominante y porque la lengua marca su autorreferencialidad.

Es interesante destacar aquí que un punto esencial de las investigaciones de Jakobson es la combinación entre metáfora y metonimia como instancias que afectan por un lado al código y por otro al contexto. Mientras la contigüidad (metonimia) está basada en la categoría de la combinación, la similaridad se 
basaría en las categorías complementarias de selección y sustitución. Así propone que el verso proyecta el principio de equivalencia del eje de la selección (eje vertical de relaciones de paradigma) sobre el de la combinación (eje horizontal de relaciones sintagmáticas) poniendo en vinculación al mismo tiempo la idea de la categoría de la similaridad con la de contigüidad.

En esta conceptualización, contemplamos más de cerca la noción de función poética del lenguaje como una relación específica con los otros elementos constituyentes de la situación lingüística.

Si bien esta definición retoma la noción de que el objeto estético tiene un valor en sí, no está sometido a fines utilitarios; sin embargo, no quiere decir que carezca de determinaciones. En realidad, la obra se refiere a la puesta de manifiesto del lenguaje y es una manera de hacer del acto de lenguaje un procedimiento literario. Es justamente el procedimiento el sujeto del discurso lierario, según Jakobson.

Entonces, esta concepción de la literaturidad, que tiende a aislar el texto de los contextos prácticos e históricos, obliga a resignificar la noción de contexto.

En este sentido, el contexto específico de la obra está constituido por la tradición literaria (la forma de la obra está determinada por las formas pretextuales) y por otros discursos literarios. Sin embargo, no son las estructuras lingüísticas y retóricas las que definen la literaturidad, pues pueden encontrarse en otros textos, sino más bien el modo de integración de estas estructuras de acuerdo con las normas de la tradición y los contextos literarios que caracterizan a la literaturidad.

Esta interdependencia funcional puede darse en tres niveles. En un primer nivel está la integración de estructuras vinculadas con una comunicación definida que significa en varios registros. La preocupación de Jakobson por la clasificación clara de los hechos lingüísticos lo lleva a afirmar que el procedimiento fundamental de la literatura es el paralelismo, al que divide en tres grupos: la comparación, la metamorfosis y la metáfora, con los que se produce un efecto semántico mediante estructuras formales. 
El segundo nivel de integración es la presunción de unidad, a través de un elemento "dominante" o una estructura unificadora, lo que hace que surjan disonancias y se produzcan muchos efectos literarios en este género.

En un tercer nivel de integración la obra significa en relación con el contexto literario, en su relación con los procedimientos y las convenciones, con los géneros literarios y los modelos por los que la literatura permite a los lectores interpretar el mundo. Esto plantea la posibilidad de leer un texto literario como un discurso autorreflexivo. En esto la literariedad es un tipo de reflexividad.

El proceso de autocrítica y superación del formalismo ruso puede verse reflejado en un momento crucial, representado por las nueve tesis acerca de los estudios formalistas redactado por Jakobson y Tinianov bajo el título Problemas del estudio de la literatura y de la lengua (1928), que constituyen un compendio cabal de la década y también una gran vuelta de página.

Se reinstalan los principales puntos argumentativos del formalismo:

- La cruzada por una ciencia literaria.

- La búsqueda de la literaturidad, reivindicando a Sklovski.

- La evolución literaria, entendida como la relación entre las "series".

- El concepto de obra como sistema en el que se produce una lucha entre los elementos intervinientes, se impone un principio constructivo o función hegemónica y como consencuencia se destaca el carácter dinámico de la estructura.

- La discusión del concepto de sincronía.

- La concepción de la obra como un sistema dentro de otros sistemas mayores, cuya relacionalidad es la base de toda investigación.

Esta última tesis abre el diálogo con el estructuralismo checo y pone en relación la literatura con la sociedad, aceptando el rol del entorno no sólo como serie lingüística.

El punto crucial para la defensa de la autonomía relativa del arte por parte del estructuralismo checo, representado por Mukarovsky, se halla en la idea de sistema, en la que se apoya el desarrollo de la ciencia semiótica. Ese sistema 
no tiene realidad aislado de la "ideología colectiva", entendida como la suma abstracta de las diferentes percepciones. Esta concepción aproxima al estructuralismo con la Teoría de la Recepción de la escuela alemana: el "artefacto material" necesitará del receptor para transformarse, gracias al apoyo de la conciencia social, en un objeto estético.

Así, el estructuralismo ingresa en un nuevo territorio y se independiza del formalismo. Este cambio se halla documentado en una revisión de Jakobson (¿Qué es poesía?, 1933-34), donde llega a decir que arte y vida forman una alianza dialéctica con el escritor y que la función poética es sólo una más de las constituyentes del texto. Declara que el artista nunca deja de serlo porque en rigor los géneros de ficción no hacen más que proveerle una máscara.

Mukarovsky, en sus ponencias de 1934 (El arte como hecho semiológico y La denominación poética y función estética de la lengua), señala que existe una antinomia entre lengua normal y lengua poética, al punto de que esta última tiene la particularidad de obstaculizar la referencialidad.

Mientras Jakobson había proporcionado la idea de la literatura como una direccionalidad hacia dentro de sí misma, para el estructuralismo checo en cambio, el arte se encuentra en el choque con la comunicatividad de la lengua común, puesto que al mismo tiempo que comunica remite a un referente.

El núcleo del pensamiento de Mukarovsky se encuentra en su aporte a una estética literaria que trasciende los límites de la teoría literaria y se funda sobre los conceptos de función, norma y valor estético ligado al de "artefacto material", que como dije anteriormente permitieron darle un espacio al receptor. Mukarovsky define la función estética como la relación entre una cosa y el fin que se propone, a la norma estética como un criterio con cuya ayuda se puede estimar la capacidad de esa cosa para realizar la función apropiada y el valor estético como la utilidad, el éxito respecto de la función.

La función estética pasó a ser la mediadora entre el signo y la realidad. La fenomenología husserliana es el paradigma que sostiene y enmarca esta afirmación. La condición de la obra como mediadora entre autor-receptor le otorga la condición no ya de expresión sino de signo.

Para Mukarovsky la diferencia ente arte y no-arte radicaría en la posición dominante de la función o el valor estético entre las funciones y valores 
contenidos en ella. Llega así a acuñar el concepto de "gesto semántico", que aúna forma y contenido (lo que en fondo sería la semantización del "principio constructivo" de los formalistas).

Por otra parte, la semantización de los elementos del texto lleva, en opinión del profesor José Amícola, a la postura que sostendrá luego Juri Lotman.

Lotman y Bajtin representan un intento de sacar a la ciencia de la literatura de su obsesión por la inmanencia. De modo que la Escuela de Tartu como corriente heredera y modificadora de una tradición entra en una red de múltiples relaciones con el grupo liderado por Bajtin.

La primera preocupación de esta rama semiológica derivada del formalismo ruso, cuyo representante es Lotman, fue la de considerar todo el espectro de la cultura como un sistema de signos donde estos últimos no sólo reflejarían los fenómenos de la vida social sino que al mismo tiempo serían modelizadores de ese mismo mundo del que son parte integrante.

La implicación última de esta corriente es que el signo no sólo es instrumento de comunicación sino que también tiene la capacidad de modelar el mundo a su imagen.

Lotman se distancia del formalismo al sostener que en un texto no se trata de vencer el material sino que el creador entra en un pacto que significa retener o violar su estructura según una elección artística consciente.

La noción de texto es muy importante para la Escuela de Tartu dado que no será sinónimo de obra literaria sino un sistema invariante de relaciones intertextuales y el lugar donde está situado el status de la obra literaria como artefacto. Texto es en definitiva equivalente a signo y aparece en dos acepciones como reproducción mecánica de una relación de equivalencia entre un plano de expresión y un plano del contenido y como una actividad modelizadora para producir significados.

Lotman establecerá en su obra La estructura del texto literario que el arte es un modo de conocimiento que acredita una especial riqueza de información. El arte produce conocimiento porque es modelización y comunicación.

La lengua natural es para Lotman un sistema modelizador primario y que es utilizada por otra instancia que llamará sistema modelizador secundario, 
entre los que se encuentran la literatura y otros discursos, como la filosofía o la historiografía.

La lengua ya no es sólo forma sino portadora de información y el movimiento clave aquí será averiguar qué es portador de información en un texto y no qué pertenece a la forma y al contenido (problemas no resuelto por investigadores del pasado).

José Amícola reconoce que la búsqueda de información en el texto es el nudo capital de enlace entre el formalismo (Sklovski) y la Escuela de Tartu (Lotman), pues está conectada con la "desautomatización" de la forma.

Así, este investigador ve al formalismo ruso como un tramo común del que salen dos corrientes: por un lado la rama semiológica representada por Mukarovsky y luego Lotman, y por otro lado la rama pragmática representada por Bajtin, con evidentes contactos entre ellas, que en su trabajo demuestra. ${ }^{12}$

El núcleo conceptual de la constelación bajtiniana se halla en su definición lingüística del enunciado. Cada enunciado presupone efectivamente otro hacia los que éste funciona como traducción, réplica o anticipación; esta situación, sin embargo, no es estable, dado que lo que caracteriza al fenómeno lingüístico va a ser su constante dinamismo. Piensa a la actividad literaria como un trabajo que se ejerce sobre otros enunciados que se responden, se rechazan e influyen unos en otros. Así es como la relación corpus literario-corpus social es dialógica. Un enunciado presupone la existencia de otros anteriores.

Esta relación dialógica deriva en sus conceptos de género primario y secundario. En este último se encuadra la literatura. Un texto literario, en cuando objeto estético en sí mismo, siempre es único y original, pero está configurado por enunciados heterogéneos y ajenos: es esencialmente dialógico.

El interés por la superposición de los discursos lo conducirá hacia la bivocalidad de la palabra, con lo que se incorpora la otredad, eje del concepto de diálogo bajtiniano. La estetización, la ironía, la parodia, son los ángulos dialógicos desde los que se confrontan discursos ajenos en los textos. Los discursos del otro significan el campo social de todos los hablantes y la narración es intersubjetiva. 
A partir de 1963, con la publicación de Bajtin de su segunda versión del tratado sobre Dostoievski, los críticos reconocen la importancia del concepto bajtiniano de novela polifónica, entendida como interacción de voces irreductibles a un discurso homogéneo.

Los principios de polifonía y dialogismo son formulaciones que abarcan todo un diálogo social. Mediante estas formas el texto traslada a su superficie lingüística no sólo otros textos o enunciados anteriores sino las marcas ideológicas de un proceso histórico-social.

Por una parte, expresa la individualidad creadora de su autor y por otra pone en diálogo diferentes visiones del mundo. Esta ida de "pluridiscursividad" se aplica especialmente a la novela como el espacio de hibridación, de encuentro de enunciados. La palabra se sitúa en la novela en el cruce del espacio y el tiempo, una dimensión a la que Bajtin denomina cronotopo. De este modo, el dialogismo se aplica a todo el corpus social y el cronotopo opera como mediación entre el arte y lo social.

Estos conceptos, aplicados primero a la novela, se desplazan luego al campo cultural precisamente por las consideraciones bajtinianas sobre la trasposición del carnaval a la literatura o carnavalización.

Lo que acabo de reseñar, cuyo hilo conductor es la noción de literatura, ha mostrado algunas perspectivas del debate. La discusión apunta actualmente a una definición de las convenciones con las que se aborda el texto literario.

En un sentido, se plantea que la noción de literaturidad es una función de las relaciones diferenciales del discurso literario y de otros discursos más que una cualidad intrínseca. Por otra parte, se puede identificar cierta literaturidad aún en fenómenos no literarios (Jakobson).

También se ha explicado la literariedad de un texto por una actitud de recepción (Mukarovsky) o por su efecto de lectura que no está localizado en marcas formales propias. Así, Terry Eagleton señala que leer equivale siempre a reescribir y que no hay obras literarias valederas por sí mismas, independientes del "valor" que una sociedad les otorgue. Esta es una de las razones por las cuales lo que se considera como literatura sufre una notoria inestabilidad. Estos juicios de valor que constituyen a la literatura son 
históricamente variables y se relacionan estrechamente con las ideologías sociales.

Desde su punto de vista resulta útil considerar a la literatura como una de las prácticas discursivas y que por lo tanto el objeto de estudio debe ser todo el campo de las prácticas. Concluye refutando la idea de la literatura como objeto privilegiado de estudio que no debe ser planteado como un a priori, el axioma según el cual lo que se nombre como literatura siempre será el centro de atención más importante y opone a la "teoría literaria" una clase distinta de discurso al que llamará "estudios culturales".

Mientras tanto, Marc Angenot presenta tres proposiciones complementarias entre sí que entiendo resultan pertinentes a la reflexión sobre el lugar del testimonio en el campo de la literatura.

La primera es que los estudios literarios no tienen objeto estable y delimitado.

La segunda tesis es que la especificidad del hecho literario, históricamente variable y múltiple, es una función de la economía global del discurso social y no se entiende en términos inmanentistas sino en términos de trabajo interdiscusivo. Recordemos que Angenot llama discurso social a todo aquello que se dice y se escribe en un estado de sociedad, a los sistemas cognitivos, las distribuciones discursivas que en una sociedad dada organizan lo narrable y argumentable.

Y la tercera tesis que completa a las dos anteriores es que el único objeto que forma una entidad propia y un campo global de interacción es el discurso social en su totalidad.

Es en el marco analítico de una teoría del discurso social donde podrán ser aislados algunos escritos que pertenecen al campo literario. "El texto literario inscribe el discurso social y lo trabaja... el trabajo sobre los discursos sociales no es una tarea transhistórica...es un trabajo siempre problemático...Si los textos literarios o no, se refieren a lo real, esa referencia tiene lugar en la mediación de los lenguajes y de los discursos que una sociedad concreta "conocen diferencialmente e incluso de manera antagónica lo real..."13

Angenot abre aquí un problema que ha dado lugar a otra concepción de la literaturidad y que pone el acento en la relación particular del discurso literario 
con la realidad. Esta relación aparece inscripta en el marco de preocupaciones filosóficas sobre la polaridad lenguaje-mundo y ha conducido a diversas interpretaciones que comprometen el concepto de representación..

Si se concibe la representación como el proceso mediante el cual la obra establece una correspondencia con el referente, parece convincente el planteo de Jean Bessière. ${ }^{14}$ Este autor distingue una disposición interna y una externa del referente, por lo que la teoría de la representación se ve conducida a una ambivalencia entre representación del mundo por un lado y representación interna a la obra, por el otro. En este marco se vuelven comprensibles las posturas representacionales y anti o auto-representacionales sostenidas por las teorías del reflejo en el primer caso y por las teorías vinculadas al inmanentismo formal en el segundo.

Esta diferencia, sin embargo, no dice nada acerca de las fronteras entre lo ficcional y no ficcional, delimitación que se asimiló históricamente a discurso literario y discurso histórico, ya que la ficción no se había visto de otro modo más que como condición de la literatura, y por lo tanto se le otorgó al discurso histórico el dominio sobre lo real. No obstante, el siglo XX ha producido diversas interpretaciones respecto de la relación literatura-ficción y ha planteado el problema de la ficcionalidad como un marco de reflexión más amplio, que involucra a la cuestión de la literariedad.

\section{Acerca de la ficcionalidad}

La heterogeneidad de perspectivas sobre lo ficcional en la teoría literaria actual no oculta sin embargo dos coincidencias: una temática, la ficción como problema, y otra epistemológica, la indagación sobre la ficción, que acaba por afectar a la totalidad del dominio teórico contemporáneo. Esta discusión se produce como consecuencia de lo que se ha convenido en llamar "crisis de la literariedad".

Como se puede observar en la reseña acerca del problema de la literaturidad que se ha desarrollado aquí, el interés por la ficcionalidad nace fundamentalmente de ese cambio de paradigma que sustituye al modelo estructuralista centrado en el texto y en las propiedades distintivas del lenguaje 
literario, por la pragmática centrada en la comunicación literaria, en el uso del lenguaje. Lo literario se indaga en tanto modalidad de recepción y producción comunicativa y en esa modalidad ocupa el lugar preeminente la ficcionalidad. Su importancia en el contexto de la teoría literaria contemporánea se explica por otro fenómeno: no es una zona más de discusión teórica sino un eje que está incidiendo sobre los diferentes lugares. Afecta a la ontología (¿qué es la literatura?), pero también a la pragmática (¿cómo se emite y recibe literatura?), a la retórica (¿cómo se organizan los textos ficcionales?), a la teoría de los géneros y a la enunciación.

Sin embargo, el problema de la ficcionalidad ha quedado circunscripto al discurso sobre la literatura cuando debería ser revisado por una semántica general o una teoría general de la ficción. ${ }^{15}$

En cuanto a la relación entre estos dos problemas centrales de la reflexión teórica (literariedad y ficcionalidad) existen dos posiciones.

Por un lado, aquellos que como Félix Martínez Bonati ${ }^{16}$ plantean que el hablar literario es un hablar ficticio, es producción de frases auténticas pero imaginarias, y así transporta la ficcionalidad a la escena misma del ser constitutivo de lo literario, con independencia del grado de realidad de los referentes extensionales.

Por su parte, Walter Mignolo ${ }^{17}$ distingue claramente las nociones de literariedad y ficcionalidad cuando diferencia los niveles de funcionamiento de la convención de ficcionalidad y de las normas institucionales. El concepto de norma queda, según Mignolo, sujeto al lugar en el que la norma se ejerce; ese lugar es el de la propia disciplina o formación discursiva que regula su actividad, establece sus fines, objetivos y criterios. La norma es una pauta recomendatoria para los participantes en una situación de comunicación literaria, lo que significa que el acto de lenguaje se propone dentro de un universo literario de sentido, mientras que la convención de ficcionalidad forma parte de los marcos de intercomprensión de los participantes en la situación comunicativa.

Aceptar esta convención implica sostener que los discursos ficcionales tienen un doble discurso: el del productor y el del narrador. De este modo, uno de los aportes más importantes de Mignolo es el salto desde los mundos 
ficcionales de la actividad textual a los mundos vivenciados y actualizados por el lector en un pacto de ficción.

La discusión sobre el estatuto de ficcionalidad, que como he dicho antes ha llegado a ser punto central en las modernas teorías sobre la literatura, presenta diversas propuestas y ángulos de perspectivas muy diferentes.

Dado el interés de síntesis que anima este apartado, ofreceré un mapa ilustrativo de las teorías que a mi juicio producen un aporte relevante, especialmente porque puestas en diálogo permiten dirimir las marcas de reflexión que sustentan la problematización teórica del relato testimonial.

Merece la pena detenerse en una posición particular sobre el fenómeno de la ficción, la de J. Searle ${ }^{18}$, quien propone una definición posible en el sentido de darle a la ficcionalidad una conexión con la teoría de los actos de habla. ${ }^{19}$

Toda la argumentación de Searle se apoya en una concepción pragmática del estatuto de ficcionalidad. La condición ficcional del discurso no depende de propiedades textuales sino de la intencionalidad del autor y de la posición del locutor respecto de su discurso.

Searle comienza su estudio estableciendo una separación entre lo ficcional y lo literario para afirmar que no todos los textos ficcionales son literarios y que no todos los textos literarios son ficcionales. A partir de esa premisa pragmática intencional, Searle explora la diferencia entre enunciados ficticios y enunciados serios, siempre en el marco de la teoría de actos de habla que reserva la denominación de serios a aquellos que comprometen una serie de reglas para la aserción como acto ilocutivo. ${ }^{20}$

Al comparar un discurso periodístico y uno literario ficcional, el autor llega a la conclusión de que el ficcional no respeta las reglas que rigen las declaraciones de verdad o actos ilocutivos, por lo tanto la pregunta pendiente es ¿qué hace el autor de ficciones cuando declara, afirma, expone o niega? A lo que Searle responde que hace "como si" hiciese una aserción, imitando el acto de hacer aserciones. La intención del autor no es engañar sino fingir, representar. Por lo tanto, la ficción literaria no sería un hablar pleno y auténtico sino un fingimiento de que se realizan tales actos ilocutivos. Se trata de un hablar no serio ni verdadero, ni falso sino "fingido", simulado. 
Esta tesis de Searle ha sido rebatida por otros autores ${ }^{21}$, entre quienes mencionaré a Thomas Pavel, quien ha ordenado una triple crítica a la teoría de los actos de ficción:

- Pone en duda las reglas en tanto considera que suponen una idealización del concepto de verdad, pues en la práctica la adhesión epistemológica marca grados de fiabilidad, nunca es un absoluto.

- Cuestiona la idea de que el locutor se encuentre en el origen del discurso de ficción, ya que la situación de comunicación "actual" y "en presencia" nunca es planteable para la experiencia literaria, que es no actual, diferida y delegada, y que ficcionaliza el rol de locutor y problematiza al mismo tiempo la espera de la recepción.

- Critica la noción de ficción como simulación pues es difícil discernir en los textos narrativos los actos auténticos, "serios", de opinión del autor, de aquellos que son fingidos, es decir que pertenecen al universo ficticio.

- Concluye su crítica a los actos de ficción de Searle sosteniendo que esta teoría parte de una idealización del concepto de "realidad" y de suposiciones sociales en el sentido de que existe un comportamiento normal y uno lúdico (no serio). Sin embargo, afirma Pavel que estos comportamientos forman un continuum constantemente intercomunicado.

Ahora bien, si el modelo del acto comunicativo predicado por la teoría de actos de habla no es extrapolable a la experiencia literario-ficcional, ¿habría un modelo de otro tipo que lo explicara?

Sin duda, un punto de tránsito entre la teoría de los actos de ficción planteada anteriormente y una semántica de la ficción (cuyo concepto es el de representación ligado a la ficción por la relación mímesis-poiesis), es la propuesta por Käte Hamburger, ${ }^{22}$ revisada luego por Paul Ricoeur. ${ }^{23}$

Hamburger postula que en su estructura fundamental la lengua es un sistema de enunciación definible como la relación entre un sujeto y un objeto de enunciación. Esta relación no es un hecho comunicacional sino que está 
inscripto en el interior de la lengua: se establece una diferencia entonces entre el sujeto de enunciación y el sujeto discursivo pragmático. En estos términos es posible la "vivencia de ficción", pues la literatura constituye mundos ficcionales dotados de autonomía respecto del sujeto de enunciación y por lo tanto no pueden ser entendidos como objetos sino como mundos cuyos personajes son ellos mismos sujetos. Se revela así la estructura lógica de la ficción, opuesta a la estructura del enunciado de realidad.

Dos son las condiciones bajo las que Hamburger define, entonces, lo ficticio. Por un lado, carece de "yo de origen real", y por el otro contiene "yoes" de origen ficticio, los personajes, que no tienen que ver temporal ni epistemológicamente con el yo real.

Una consecuencia aún más importante de estas dos premisas afecta lo narrado. El relato ya no es la mímesis de un acto de lenguaje fingido sino una mímesis de realidad: representación, imagen, ilusión de vida. Como resultado de estos tres fenómenos se encuentra la realidad, contada como verdadera, como ilusión: sólo si se independiza de un sujeto de enunciación real puede ser vivida y representada en su verdad actual por un lector.

Al afirmar que el mundo ficcional construye su propio contexto de producción de discurso, Hamburger se acerca a las teorías que de inmediato analizaré y que postulan una semántica textual literaria.

Se trata de proponer, como lo ha hecho Pavel, modelos de verosimilitud que son internos a las estructuras de realidad creadas por el discurso. Las obras de ficción son instrumentos de un juego de presentación verosímil cuya credibilidad no está referida al mundo real exterior sino a las propias reglas del juego. Lo que se entiende por verdadero no siempre coincide con lo real, es un mundo alternativo.

En el modelo de Pavel, los mundos de ficción responden al esquema de una estructura dual: el universo primario, real, que sirve de base al universo secundario, imaginario, vinculado por una relación de correspondencia. Dicha relación puede ser isomórfica, si la correspondencia es de término a término (como en los juegos infantiles) o no es isomórfica, como en los mundos ficcionales a los que llama estructuras salientes. ${ }^{24}$ 
Según Pavel hay una dualidad esencial a la propia convención que regula la relación entre los universos y en virtud de la cual hay imagen de realidad que se traspone y realiza como verdadera, aunque siendo imagen es en cambio sentida como no imagen, como mundo.

Esta teoría de Pavel encuentra fundamentos teóricos en la semántica de los mundos posibles para elaborar su hipótesis sobre la semántica de los universos de ficción. Pero para Pavel la única ontología posible de la ficción es aquella que refleja la profunda heterogeneidad de los textos en que se inscribe y la descripción de estos textos no puede ser sólo semántica sino también genérica, pragmática y estilística. Se trata de pasar de la creación de mundos posibles a la de mundos ficcionales que tienen existencia textual.

Otros autores han creído posible desarrollar una semántica de los mundos posibles literarios. Me referiré a continuación a las propuestas de Lumezil Dolezel, Walter Mignolo y Umberto Eco.

Dolezel sostiene que una frase narrativa ficcional es verdadera si expresa un estado de cosas existente en el mundo ficcional del texto. Pero esta definición necesita completarse con una teoría de los conceptos sobre los que se basan los valores de verdad de las frases narrativas. Uno de ellos es el de existencia ficcional, cuya premisa es salir del prisma realista para desembocar en una semántica de mundos posibles. Y el otro concepto relevante es el de valor de verdad referido a la función textual que lo crea. Al respecto, Dolezel afirma que no es el autor real el que determina el valor de verdad de las frases textuales sino la textura formal que imagina fuentes ficcionales: el habla del narrador y los personajes. La palabra del narrador tiene autoridad de autentificación y es esta función el principio fundamental que gobierna la estructura del mundo ficcional.

Dolezel piensa que es preciso una semántica de la ficcionalidad que realice una apropiación no mecánica del concepto de mundo posible sino que pueda explicar los particulares ficcionales, la particularidad de los mundos ficcionales literarios al ser corporeizados en los textos literarios. Para ello es preciso una fusión de la semántica de los mundos posibles con la teoría textual y la semántica literaria. La explicación de Dolezel se funda en tres tesis: 
- Los mundos ficcionales son posibles estados de cosas y ejemplifica diciendo que aunque Hamlet no es un hombre real es un individuo posible que habita el mundo ficcional de la obra de Shakespeare.

- La serie de los mundos ficcionales es ilimitada y lo más variada posible: no hay restricción de la literatura a ser imitación de ningún mundo real. Así, los mundos de la literatura realista no son menos ficcionales que los mundos del cuento de hadas o de ciencia ficción.

- Los mundos posibles son accesibles desde el mundo real: el acceso desde el mundo de lo real existente al de lo ficcional posible se realiza a través de canales semióticos. La teoría literaria estudia esas mediaciones y canales semióticos a través de los que se comunica y transforma un mundo u otro.

A partir de estos tres principios, Dolezel ofrece también tres rasgos específicos de la ficción literaria.

1. Los mundos ficcionales son incompletos y en ello radica su eficacia estética, pues presentan "huecos" que el lector debe llenar con sus competencias literarias. Así también lo plantea Umberto Eco, en cuya propuesta me detendré más adelante.

2. Los mundos ficcionales son semánticamente no homogéneos.

3. Los mundos ficcionales son constructos de la actividad textual. La teoría literaria tiene la responsabilidad de establecer los mecanismos textuales por los cuales mundos posibles no verdaderos cobran capacidad de existencia ficcional. Ésta es, como se podrá ver de inmediato, la tesis que comparte con Eco.

En lo que respecta a la relación mundo posible-mundo ficcional como estructura textual, Umberto $\mathrm{Eco}^{25}$ ha ofrecido una sólida teoría que subordina el concepto de mundo posible al de estrategias textuales y a la actividad del lector modelo.

Eco ha insistido en que los mundos posibles no pueden ser vistos como "estados de cosas" reales sino como estructurales culturales, como material de una producción semiótica. Ese constructo textual es una estrategia que el lector modelo interpreta y allí los mundos posibles se articulan como disyuntivas constantes en el uso de la narratividad. Los mundos posibles son estipulados y 
no descubiertos, son parte de las presuposiciones, interpretaciones que la enciclopedia del lector modelo va actualizando en el proceso de decodificación.

Los aportes de Umberto Eco apuntan a crear una semiótica propia de los mundos ficcionales literarios.

Sin embargo, el problema para la teoría de los mundos ficcionales no es sólo la realización de una semántica literaria conectada a una semiótica textual, sino también su relación con una pragmática que contemple las conexiones entre ese mundo y el lector que lo constituye.

Esta consideración obliga a detenernos en la teoría de Walter Mignolo, quien también ha concedido al lector un papel fundamental en la construcción del mundo de ficción.

Mignolo sostiene la necesidad de contemplar la ficción literaria en el marco de situaciones comunicativas regidas institucionalmente por la vía de los géneros y por la competencia literaria. Escribir ficción implica crear un "espacio ficticio de la enunciación" donde el narrador unifica y compone ese espacio y donde no existe co-referencialidad entre su discurso y el del autor. Esta es la marca distintiva de la convención de ficcionalidad.

El lector interpreta los mecanismos de la semántica del discurso ficcional literario y los incribe en el proceso de semiotización como usos convencionales. El pacto de lectura resultante determina que el discurso ficcional es verdadero en tanto crea "ilusión de verdad".

Mignolo aborda finalmente lo que llama semantización denotativa, que debe entenderse como la creación de una situación ficcional de enunciación que "verdaderamente narra y describe acciones ocurridas y objetos existentes". ${ }^{26}$ Propone además que la creación de entidades ficcionales es pertinente cuando se analiza el acto de lenguaje del autor en relación con su audiencia. De modo que los objetos son creados y existen en ese mundo porque el narrador los autentifica. El concepto de autentificación designaría la operación que realiza el narrador no en el mundo actual sino en un mundo alternativo. El narrador no crea, autentifica; las acciones no son creadas sino que existen. Este el procedimiento básico de la semantización denotativa según Mignolo, quien ha ofrecido un despliegue de problemas que amplían la 
propuesta básica de Dolezel y coinciden con Eco en el papel que le conceden al lector.

Una reseña de los problemas aquí solamente esbozados, que aborda una teoría de la ficcionalidad, no puede construirse al margen de los aportes de un autor como Paul Ricoeur. Con su teoría de la triple mímesis, Ricoeur establece una perspectiva sobre la ficcionalidad que se comunica con tres dominios de la figuración:

1. Un dominio de prefiguración (mímesis I) que contempla las presuposiciones y asunciones que un lector tiene como dadas.

2. Un dominio de la configuración (mímesis II) que incluye una actividad creadora de trasposición del campo de lo real al campo poético mediante el relato.

3. Un dominio de refiguración (mímesis III) que hace intervenir la actividad del receptor.

La importancia de este modelo radica en que se constituye en una explicación de la poiesis aristotélica que hace coincidir con mímesis, en tanto ambas operaciones implican una actividad de composición.

La mímesis como representación es sinónimo de invención creadora, en tanto ambas intervienen en la configuración de la trama, ordenación de los hechos para producir un relato.

La tesis dominante de esta obra es que la temporalidad es "la estructura de la existencia que alcanza el lenguaje en la narratividad" y que la narratividad es "la estructura del lenguaje que tiene a la temporalidad como su referente último". ${ }^{27}$ Por lo tanto, se anula toda diferencia entre relato histórico y relato ficcional, fundado sobre criterios de realidad-imaginación.

El espacio de la ficción es el espacio de la semántica textual. Se produce una trasposición del campo práctico al poético, el fenómeno de configuración, y luego es el lector quien produce una refiguración recepcional, en un encuentro entre mundo del texto y mundo del lector.

Del trazado de este mapa teórico acerca de la ficcionalidad y la literaturidad se desprenden algunas consideraciones que me interesa señalar:

- Una teoría de la ficción se encuentra afectada simultáneamente por tres dominios de investigación: los aspectos semánticos en tanto 
ficcionalidad del enunciado y relación entre los mundos ficcionales; los aspectos pragmáticos que plantean a la ficción literaria como constitutiva del circuito de comunicación, y los aspectos estilísticos que remiten a los géneros y a las convenciones de la ficción.

- Acerca de la ficción existen dispares explicaciones teóricas, desde lugares de reflexión diferentes. Sin embargo, se pueden delimitar tres centros de interés: la reconsideración siempre problemática de literatura y realidad; la relevancia de la figura del sujeto en el marco de una teoría de la enunciación y la relectura de los conceptos de mímesis y poiesis.

- Una teoría de la ficción literaria debe atender a una evidencia: la ficción es también una institución en el seno de una cultura, de modo que la relación entre lector-texto ficcional no ha sido siempre la misma. Las fronteras entre lo ficcional/no ficcional han fluctuado en un arte diacrónico y aún fluctúan en una perspectiva sincrónica. Esas fronteras, por lo tanto, son históricamente variables.

- Existe hoy una constante interacción entre el mundo ficcional y el no ficcional; ambos dejan sus huellas en la visión del mundo del lector.

- La discusión sobre la ficcionalidad conduce a presuposiciones sobre la literaturidad que destacan en la obra una organización compleja e intensa del lenguaje, pero que también problematizan la relación literatura-mundo.

- La cuestión acerca de la relación testimonio-literatura se resuelve en una consideración sincrónica y no aislada por un gesto arbitrariamente fundado, sino sobre la base de la interdiscursividad, como operación que permite la interacción de los distintos campos discursivos en la totalidad de la producción social del sentido y de la representación del mundo de una sociedad.

- El ideologema predominante de las prácticas significantes de este fin de siglo, y de la literatura en particular, es la aceptación de la abolición de las fronteras entre la ficción y el discurso referencial, entre el discurso mismo y el mundo empírico. Claro ejemplo de esto es la ficcionalización creciente del relato testimonial por su ingreso a la novela. 
- El ingreso del relato testimonial al campo de la literatura y la ficción pone de relieve la problemática relación entre el discurso literario y el discurso histórico y el periodístico. Esta cuestión nos conduce a considerar la importancia de la novela como universo interdiscursivo, tema que desarrollaré en el siguiente apartado.

\section{Acerca del género}

Si bien no es objetivo de este trabajo crear una tipología sino realizar una descripción del corpus a partir de los principios organizadores enunciados, creo relevante hacer algunas distinciones entre la autobiografía y el testimonio, así como identificar los matices que diferencian de la novela testimonial lo que llamaré el discurso testimonial. Es importante destacar, previamente, que todos estos tipos discursivos responden a la modalidad narrativa.

\section{- $\underline{\text { Testimonio y novela }}$}

El relato testimonial se presenta de dos formas y con diferente función. Por un lado, como un texto narrativo homodiegético con intención explícita de brindar una prueba de verdad de un hecho social previo y documentado. Está garantizado por un marco: prólogo y epílogo, y un sujeto narrador testigo o actor de los acontecimientos narrados. Estos rasgos básicos corresponden a lo que los críticos llaman testimonio. Son ejemplos de esta categoría Nunca más (Informe de la CONADEP) ${ }^{28}$ y Ni el flaco perdón de Dios, de Juan Gelman y Mara La Madrid.

Por otro lado, constituye una estrategia narrativa que en la escritura de la novela se propone otorgarle sentido de veracidad a lo narrado. Así se presenta en La memoria en donde ardía, de Miguel Bonasso, o La novela de Perón, de Tomás Eloy Martínez, por mencionar algunos ejemplos.

Sin embargo, me interesa particularmente una tercera manifestación del relato testimonial, la novela testimonial, ya que las características del corpus que abarcaré así lo imponen. Esta cuestión tiene diversos alcances teóricos. En primera instancia, hablar de novela testimonial obliga a hacer referencia a la 
"novela-testimonio", como marco para definir sus características propias. Pero también será necesario plantear su relación con la "novela histórica", expresión que designa un corpus literario abundante y que plantea varios problemas a la reflexión teórica, pero que puede considerarse una denominación natural originada en la crisis de la narración contemporánea.

Creo oportuno detenerme ahora en el concepto de novela-testimonio acuñado por Miguel Barnet, en tanto es el antecedente de novelización del género. Este escritor entiende que novela no es más que una variante del relato, de aquél en el que como en un todo orgánico se mezclan y se confunden la razón y el mito. Piensa que lo que hoy llamamos novela no es eficaz, ha entrado en crisis, pues la llamada novela de ficción no es capaz de trastornar ninguna costumbre, de ahondar en la conciencia de la realidad, no le exige al lector un replanteo de posiciones ni de actitudes. Frente a este panorama surge la novela-testimonio, a la que Barnet le confiere las siguientes características:

* Se propone un desentrañamiento de la realidad tomando los hechos principales, los que han afectado a la sensibilidad del pueblo, describiéndolos por boca de uno de sus protagonistas más idóneos.

* La supresión del yo, del ego del escritor, como una propiedad esencial del montaje del testimonio.

* Tiene un sentido histórico, para dotar al lector de conciencia de su tradición y de un conocimiento de la realidad como conocimiento de sí mismo. El lector debe hallarse en la novela como si fuera un personaje más.

* El gestor de la novela-testimonio tiene la misión de revelar "la otra historia”, por eso debe investigar.

* Es superlativo el valor de la oralidad. Los personajes deben poseer el dinamismo que les otorga la lengua hablada.

* Lo estético está subordinado a lo funcional y práctico. En la novelatestimonio se articula la memoria colectiva, el nosotros y no el yo. 
Existe otra posición al respecto, la de John Beverly, quien disuelve todo parentesco entre testimonio y novela. Las bases de su propuesta se apoyan sobre argumentos esenciales: el carácter eminentemente burgués de la novela, la identificación de literatura-ficción, el énfasis en el aspecto no literario y factual del testimonio, su carácter subversivo. Por su parte, Elzbieta Sklodowska afirma que esta posición de Beverly es difícil de sostener porque no considera la evolución de la novela en los términos propuestos por Mijail Bajtin, postura a la que adhiero y que es precisamente uno de los pilares de mi disenso con Beverly.

Conviene recordar aquí algunas conceptualizaciones de Bajtin, quien en 1928 define la noción de enunciado como una unidad de comunicación discursiva en la que queda inscripta la situación de enunciación. Piensa a la actividad literaria como un trabajo que se ejerce sobre enunciados que se responden, se rechazan e influyen unos a otros. Así es como la relación corpus literario-corpus social se define como dialógica. Esta relación dialógica deriva en sus conceptos de géneros primario o simple y secundario o complejo. En este último se encuadra a la novela: un texto literario que en cuanto objeto estético en sí mismo siempre es único y original, pero está configurado por enunciados heterogéneos y ajenos.

En la década del sesenta, Bajtin completa la noción de dialogismo con la polifonía, cuando determina la pluridiscursividad de la novela, entendida como interacción de voces. Esta comunicación dialógica original se realiza a través de lo que llama la palabra bivocal, que se funda en el cruce del yo y del otro e incluye la palabra ajena junto a la del narrador y los personajes. Los discursos del otro se confrontan a través de la parodia, la estilización, la ironía, significan el campo social de todos los hablantes y constituyen la narración intersubjetiva.

Según Bajtin, mediante formas dialógicas el texto traslada a su superficie lingüística no sólo otros textos o enunciados anteriores sino las marcas ideológicas de un proceso histórico-social. Por una parte, expresa la individualidad creadora de su autor y por otra pone en diálogo diferentes visiones del mundo. Esta idea de pluridiscursividad se aplica especialmente a la novela en cuanto espacio de hibridación, de encuentro de enunciados. La palabra se sitúa en la novela en el cruce del espacio y el tiempo, una dimensión 
a la que denomina cronotopo. De este modo, el dialogismo se amplía a todo el corpus social y el cronotopo permite un intercambio entre el arte y lo social, que a su vez se produce en un mundo social que se desarrolla históricamente. Este conjunto de ideas bajtianas son el marco de algunas propuestas críticas que perciben a la novela como discurso de orígenes múltiples y en constante transformación, conforme con la evolución histórica.

Parece ilustrativa de esta afirmación el análisis de Marthe Robert, que ofrece una imagen del espacio novelístico cuya ley única es la expansión indefinida, la conquista de ámbitos vecinos, la apropiación de amplios sectores de la experiencia humana de las que genera una reproducción o interpretación. Robert define a la novela como un "género revolucionario y burgués, democrático por vocación y animado de un espíritu totalitario que lo lleva hasta la arbitrariedad..."29

Desde la propuesta de esta autora, la novela es depositaria de una paradoja: se presenta siempre como muy ligada a la verdad, pero sin embargo la verdad de la novela no es nunca otra cosa que su poder de ilusión, de "tratar de hacer creer". Ya se base en un hecho real o sea inventado, no es el argumento lo que define al género novela, ya que, según Marthe Robert, todo es ficción, en un mundo creado para ser escrito.

Barbara Foley ${ }^{30}$, en una reseña de la evolución de la novela, demuestra que la novela documental es un tipo ficcional diferente que se instala entre el discurso factual y el discurso ficcional, y que no propone eliminar los bordes sino representar la realidad mediante sentidos acordados bajo la convención de ficcionalidad; el pacto ficcional reclama alguna validación empírica pues aspira finalmente a decir la verdad.

Esta concepción de Foley deriva de su tesis de que los discursos ficcional o factual no poseen una esencia inmutable, por lo tanto están sujetos a variaciones provocadas por los cambios de las convenciones literarias o de la estructuración de las relaciones de producción e intercambio.

Foley explica así que la diferencia no es de clase sino cualitativa. Subyace en sus afirmaciones un concepto de mímesis como práctica social por la cual el autor imparte un tipo particular de conocimiento a sus lectores. Conocimiento reconocido a través de un contrato de género cuyo propósito es evaluar la 
actualidad histórica del pasado y del presente. Ingresar en un contrato mimético es un acto ideológico, dado que la representación ficcional es una actividad de persuasión y propone valores éticos e históricos creyendo que el lector los asumirá.

En este marco conceptual, Foley realiza una descripción de la evolución de la novela trazando un ciclo desde la novela pseudo factual de los siglos XVII y XVIII a la novela histórica del siglo XIX, hasta la novela documental moderna del siglo $\mathrm{XX}$ y sus ramificaciones: la autobiografía ficcional y la novela metahistórica.

Foley identifica en cada momento diferentes estrategias para provocar el efecto documental de la novela. Define a la novela pseudo-documental como un género en prosa de ficción cuya convención primordial es la imitación paródica del discurso no ficcional.

En tanto, la novela histórica es considerada el modo dominante de la novela documental, es una forma paradigmática del género en el siglo XIX. Sus estrategias de representación difieren en tres aspectos en relación con la ficción actual: en primer lugar, el texto propone una forma de conocimiento a través de la representación de un referente, los caracteres se presentan como verosímiles en tanto son tipos representativos; en segundo lugar dirige toda su energía narrativa a la elaboración de un modelo de conflicto y resolución que interpreta y evalúa el mundo social, y, finalmente, el tercer aspecto es que los datos empíricos ingresan a la novela histórica no para validar la honestidad del autor sino para reforzar el objetivo del texto, producir una interpretación persuasiva de su referente. En síntesis, la estrategia representacional de la novela histórica propone un nuevo programa epistemológico cuyo punto de partida se encuentra en la teoría sobre el realismo de György Lukács.

Finalmente, Foley describe a la novela documental moderna del siglo XX, cuyas características esenciales son: el referente no son los hechos sino los documentos que la historia provee; su función ya no será escribir la verdad sino crear un escenario en el que surge una nueva noción de escritura, ya no considerada como instrumento sino como construcción de mundo, y es la distancia temporal lo que la hace histórica. 
La novela documental presenta dos manifestaciones: la autobiografía ficcional y la novela metahistórica. Ambas comparten algunas premisas ideológicas, como la enfática crítica a la noción de sujeto y de objeto que sostiene el positivismo, o la problemática relación entre dato y ley, particularización y generalización.

En la autobiografía ficcional la validación del testimonio personal ataca a uno de los aspectos centrales de la ficción modernista, las odiseas del artistahéroe hacia el conocimiento de sí mismo.

Para los propósitos de la autobiografía ficcional, el lector debe aprehender sus caracteres y hechos centrales como entidades reales, más que como una construcción mimética. Está fundada, por lo tanto, en la paradoja de una actividad discursiva que privilegia la trascendencia de la actualidad histórica pero que a la vez está insistentemente atada a la historicidad y a lo personal.

El texto abandona el sentido de lo real (el que se deposita en un sujeto indeterminado por su objeto) y privilegia la omnisciencia del realismo (que se deposita en un objeto indeterminado por su sujeto). No obstante, su contrato genérico solicita al lector que consigne el centro de la interpretación en el artista-héroe quien como ego-cogitans central produce conocimientos de la actualidad histórica proclamando su alienación de la actualidad.

La invocación de documentos da sentido a las garantías de autenticidad de una persona que descubre su esencia y su identidad fuera de toda concreción histórica.

La otra manifestación de la novela documental que Foley menciona, la novela metahistórica, presenta directamente el problema del proceso histórico. Invoca muchas convenciones de representación de la ficción histórica, aunque no asume que la actitud histórica constituye un objeto de conocimiento por sí.

El artista-héroe de la autobiografía ficcional resurge como el historiador creativo, quien, además del referente del texto, llama la atención sobre las abstracciones ideológicas que mediatizan la concreción del referente del texto.

Por su parte, la novela metahistórica refuta claramente la ilusión empirista sobre la subjetividad neutral y la ilusión positivista sobre la objetividad neutral. Se introduce en los "hechos" documentados sólo para cuestionar su status ontológico, más que para asumir su valor como registradores de "verdad". 
A la luz de estos aportes, una interpretación del relato testimonial como una de las manifestaciones del género novela tal vez no resulte tan injustificada como sugiere Beverly. Es imprescindible recordar el ensayo de Bajtin sobre la épica y la novela, en el que ha observado que "en las épocas de dominio de la novela casi todos los demás géneros en mayor o menor medida se 'novelizan'31, y si a ello agregamos las voces desde otras disciplinas podemos ampliar estas conclusiones. Efectivamente, Marc Angenot la define como un dispositivo interdiscursivo cuando afirma que "la novela es, entonces, el encuentro inesperado por la mediación de la coartada ficticia, de la sublimidad estética, de hechos diversos y de grandes saberes (científicos, filosóficos) ... no se limitan a préstamos, sino que producen una concretización ficticia de objetos dóxicos procedentes de otra parte..." ${ }^{32}$ Es posible comprender que al incorporar diversos textos la novela emerge renovada para responder a las exigencias de su momento histórico y se presenta como "nueva novela histórica". 33

\section{- Nueva Novela Histórica}

Trataré ahora de esbozar una caracterización del género recuperando las reflexiones de algunos teóricos cuyos aportes resultan a mi criterio significativos para fundamentar la relación entre la nueva novela histórica y el relato testimonial.

Noé Jitrik ${ }^{34}$ recurre al concepto de imaginario social al que define como un sistema entrecruzado de textos y experiencias, para explicar el surgimiento de la novela histórica en el fin de siglo XIX. Ese imaginario responde a dos tendencias: el afán de reconocerse y la búsqueda de identidad. Esta posición de Jitrik resulta útil en tanto implica una manera de explicar el texto literario como una construcción que, dentro del universo de nuestra cultura, se inscribe en un imaginario social determinado por condiciones variables en el tiempo y constituye por lo tanto una formación simbólica que se basa en exclusiones e inclusiones. El texto opera como la trasposición de ciertas prácticas sociales a figuras que se inscriben en el horizonte histórico y tiene una finalidad: orientar al hombre para interpretarse individual y colectivamente. ${ }^{35}$ 
Es importante señalar que en el nivel de las representaciones simbólicas de la literatura esta búsqueda tiene dos manifestaciones: el presente se explica como fuga hacia el pasado, y entonces aparece la novela histórica, o bien como una fuga hacia lo desconocido y la interioridad del sujeto, y surge así el relato fantástico.

Sin duda, de esta conceptualización se deduce que la representación humana que produce la nueva novela histórica está inscripta en un imaginario diferente del que dio origen a la novela del siglo XIX. La pregunta obligada entonces es: ¿Cuáles son los elementos constituyentes que dan cuenta de las relaciones dificultosas entre el individuo y la sociedad en la nueva novela histórica?

Un principio de distinción es que toma el material histórico y lo explica. Su fuente es siempre sesgada, pues se trata de un amplio horizonte de documentación y la explicación conlleva responsabilidad ideológica y efecto político.

Un segundo aspecto digno de mencionar es que la novela contemporánea se caracteriza por representar una conciencia de la experiencia histórica como correlato vivencial de la fragilidad con la que el hombre se percibe a sí mismo. No se trata ya del héroe que supera la muerte sino de aquél que está siempre tentado por el suicidio.

En tercer lugar cabe mencionar que mientras la novela histórica tradicional trabajaba con un contexto histórico, la nueva novela histórica agrega el co-texto: el narrar del pasado está condicionado explícitamente por las condiciones políticas ideológicas que determinan su escritura.

Finalmente, la nueva novela histórica representa una instancia de transformación de la novela que afecta a su propia construcción pues se modifica la noción de trama, al construir un nuevo verosímil. Este proceso de transformación tiene dos implicancias: por un lado confirma la concepción bajtiana de la novela, ya que se diferencia de otros géneros, como la épica, porque admite que las reglas constitutivas de la trama sean constantemente renovadas. Por otro lado abandona el concepto aristotélico de trama, que la novela del siglo XVII interpretó como mímesis de acciones de una totalidad que tiene principio, medio y fin, mientras que la novela del siglo XVIII invierte las 
prioridades y entiende que la trama es representación de caracteres sobre el fondo de situaciones sociales. Para la nueva novela histórica la trama se construye en la interdiscursividad (con la historia, el periodismo) y constituye la esencia del relato, en tanto estructura de la relación sujeto-mundo en una imitación poiética. ${ }^{36}$

Esta configuración narrativa de la nueva novela histórica abre un espectro de problemas que me interesaría abordar en lo sucesivo y que me obliga a volver sobre cuestiones desarrolladas en los apartados anteriores.

En principio, es necesario destacar que el eje en torno al cual giran estos planteos es el de la relación historia-ficción, que remite a dos problemas abordados previamente: el de la representación y el de la ficcionalidad.

Sobre el primero, creo que el aporte de Noé Jitrik en cuanto al discurso de la novela histórica resulta esclarecedor, más aún cuando se habla de novela en un sentido bajtiano del término. Jitrik dice al respecto que el "referente" es algo que existe previamente en el discurso histórico y que pasa, mediante mecanismos de representación propios de una relación simbólica con las cosas, a ser "referido". Esa representación se construye, y no es pasiva sino teleológica. Sus finalidades son de diverso orden: estéticas, políticas, lúdicas. Sin embargo, todas ellas, según Jitrik, son accesorias pues estarían subordinadas a una mayor y más amplia: la comprensión de una identidad, aspecto que retomaré posteriormente.

Ahora bien, el resultado del acto de representar nos reubica frente a la propuesta de Jean Bessière, que desarrollé en páginas anteriores y que reconoce una relación externa entre lenguaje-mundo y una relación interna. La nueva novela histórica establece una relación indirecta o diferida. En este sentido la literatura constituye un mundo cuyo referente no es el mundo real sino otros relatos. El horizonte de construcción del relato son los relatos prearticulados que forman parte del espacio simbólico de la escritura. Desde este punto de vista el relato se constituye en una estructura explicativa tanto del relato histórico como del relato ficcional literario.

En cuanto al segundo problema, la delimitación de ficcional-no ficcional, la nueva novela histórica se instala en la semántica de mundos posibles, cuyos presupuestos he enunciado en el apartado anterior. Esta teoría es productiva 
porque confirma la existencia de verdades alternativas a las planteadas por el discurso histórico.

En virtud de lo que he venido desarrollando hasta aquí, es posible sostener que la nueva novela histórica propone una lectura de la historia que produce un efecto de sentido político. Esta afirmación se apoya sobre tres planos que explican los procesos de lectura y escritura.

* La interdiscursividad narrativa supone una intersubjetividad. Consecuentemente el relato se presenta como un espacio social en el que el sujeto constituye su identidad.

* La narración pone en escena la acción: el proceso de representación simbólica del pasado lleva a la relación memoriaimaginación-identidad.

* El sujeto narrativo, desde su identidad no individual sino colectiva, produce una versión del proceso total de la historia.

La narratividad es el paradigma que sustenta la relación historia-ficción y se presenta en el valioso aporte de teóricos que provienen de diferentes tradiciones intelectuales, como Hayden White y Paul Ricoeur, quienes recuperan esta cuestión para el pensamiento historiográfico y también para la teoría literaria.

Hayden White ${ }^{37}$ produce un desplazamiento de la problemática y coloca a la historia en el espacio de la ficción. Ambas comparten la estructura narrativa, por lo tanto pertenecen a la misma clase. Se trata de saber si se puede reclasificar la historia como artefacto literario sin descalificarla como científica.

En un ensayo que se titula justamente "El texto histórico como artefacto literario" ${ }^{38}$, White plantea que el objetivo del historiador es familiarizarnos con lo no familiar y para ello debe usar más la lengua figurativa que la técnica. Por lo tanto, la narrativa histórica puede hacer uso de los tropos de la ficcional, en tanto ambas son artefactos verbales. Algunas de esas figuras retóricas son la metáfora, la metonimia, la sinécdoque y la ironía.

Para White, la diferencia entre historia y ficción radica solamente en el tipo de eventos de que se ocupan, de acuerdo con una convención. Define a la obra histórica como una estructura verbal en forma de discurso de prosa 
narrativa que dice ser una imagen de procesos pasados con el fin de explicar lo que fueron representándoles: "Todas las narrativas no son simplemente un registro de lo que aconteció... sino que es una redescripción progresiva de eventos, de manera de desmantelar una estructura codificada en un modo verbal a fin de justificar una recodificación de él en otro modo..."

En tanto, Paul Ricoeur postula un entrecruzamiento que descansa sobre la ficcionalización de la historia y la historización de la ficción. Para explicar esta afirmación podemos remitirnos a dos cuestiones claves: la de las tres mímesis y la de la temporalidad.

A la primera me referí en el apartado anterior. En cuanto a la segunda es necesario destacar la noción de presente histórico mediante la cual se explica una dialéctica entre el pasado y el futuro; más precisamente, se trata de una dialéctica entre lo que Ricoeur llama "horizonte de espera" y "espacio de experiencia”. El valor de estos conceptos está dado por su implicancia ética y política: se trata de resistir a las utopías puras para suscitar un compromiso responsable en el presente con el pasado y el futuro; y también luchar contra la tendencia a considerar al pasado desde el ángulo de lo acabado e inmutable. Es necesario abrir el pasado y reavivar en él las potencialidades incumplidas.

Se explica así la noción de tradición entendida como tradicionalidad, como una cadena de interpretaciones y reinterpretaciones del pasado, que se actualizan en el relato.

La historiografía en tanto conocimiento basado en huellas depende de textos que le dan al pasado un estatuto documental. La huella como efectosigno vale por el pasado. En ese "ver como" interviene la representancia, que no hace más que explicar la travesía del tiempo a través de la huella. Por lo tanto, el pasado ya no es observable sino memorable. La representancia es a la historia lo que la lectura es a la obra literaria; el entrecruzamiento historiaficción implica el acto de lectura en el que ambas convergen.

La ficción es, según Ricoeur, relevante y transformadora respecto de la práctica cotidiana. Relevante en el sentido de que presenta aspectos ocultos y transformadora porque una vida así encaminada es otra vida. La condición cuasi histórica de la ficción le da una función liberadora: "El cuasi pasado de la 
ficción se convierte así en el revelador de los posibles escondidos en el pasado efectivo". ${ }^{40}$

Desde esta perspectiva la función de la ficción se potencia frente a la memoria del horror. El horror niega la admiración, propia de la historia de los vencedores, y va unido a acontecimientos que no se deben olvidar jamás, aquellos que constituyen la historia de las víctimas. La ficción tiene el poder de suscitar una ilusión de presencia que expone el pasado frente a la explicación y también al sentimiento. En esta refiguración del tiempo se opera el entrecruzamiento de la ficción y la historia.

Como consecuencia de este cruce presenta una problemática que abarca a la identidad narrativa, de un individuo o de una comunidad, a quien se le asigna la acción de la narración que se convierte en su historia; una historia refigurada constantemente por un tejido de relatos recibidos y producidos.

Ricoeur plantea que la identidad narrativa no es estable y sin fisuras sino que siempre es posible urdir tramas diferentes sobre su propia vida y agrega que "a este respecto se podría decir que el intercambio de las funciones entre la historia y la ficción, el componente histórico del relato sobre sí mismo saca a éste de la vertiente de una crónica sometida a las mismas verificaciones documentales que cualquier otra narración histórica, mientras que el componente de ficción lo saca de la vertiente de las variaciones imaginativas que desestabilizan la identidad narrativa". ${ }^{41}$

Luego analiza el acto de lectura para decir que la práctica de la narración consiste en una experiencia de pensamiento que ejercita la imaginación además de la voluntad. La narratividad no está desprovista de una dimensión narrativa y valorativa fomentada por el narrador, que intenta imponer al lector una visión del mundo, una nueva valoración. En este sentido, el relato pertenece al campo ético y el lector se convierte en un "iniciador de la acción". Así es como la narración se une a la identidad narrativa de un sujeto pragmático, y alcanza su efecto trascendente.

Hasta aquí he presentado las características de la nueva novela histórica, sus diferencias con al novela histórica del siglo XIX y los problemas teóricos que se suscitan por su aparición en el campo cultural. En este marco general, me interesa señalar que la nueva novela histórica se bifurca en tres 
modalidades sobresalientes ${ }^{42}$ : la metaficción historiográfica, la novela autobiográfica y la novela testimonial, cuyos rasgos distintivos trataré de deslindar a efectos de delimitar el lugar del relato testimonial, que es el tema central del que me ocuparé.

La metaficción historiográfica es según Linda Hutcheon ${ }^{43}$ un nuevo tipo de escritura que se produce en el encuentro entre la metaficción y la historiografía, y cuya importancia se define en términos de su habilidad para cuestionar el conocimiento absoluto del pasado y ahondar en las implicaciones ideológicas de las representaciones del pasado y del presente.

Ante esta definición general creo conveniente detenerme en el concepto de metaficción, el que según Patricia Waugh ${ }^{44}$ abarca a los escritos ficcionales que consciente y sistemáticamente formulan una crítica de sus propios medios de construcción y problematizan la relación ficción-realidad. Esta condición, muy afincada en la novelística de los últimos veinte años, hacen de la narrativa una escritura autorreflexiva. Lo que une a todos los escritores es que exploran una teoría de la ficción a través de la práctica de la escritura de ficciones.

La metaficción pone de relieve varios dilemas: por un lado, una concepción del lenguaje como constructor del sentido de "realidad"; ya no se sostiene la noción simple del lenguaje que refleja pasivamente a un mundo objetivo. Por otro lado, el mundo como tal no puede ser representado. En la ficción literaria sólo es posible representar los discursos sobre el mundo.

En tercer lugar, plantea una cuestión propia del género, pues la metaficción es una práctica tan antigua como la novela, es una condición que le otorga su identidad y la base que sustenta esta afirmación se encuentra en la concepción bajtiana del diálogo y la polifonía, inherentes al género.

En cuarto lugar, la metaficción genera una tensión formal, pues quiebra la distinción entre creación y crítica y las sumerge a ambas en los conceptos de interpretación y deconstrucción.

Finalmente, la escritura metaficcional contemporánea es a la vez una respuesta y una contribución al pensamiento de que la realidad y la historia son provisorias: no existe más un mundo de verdades eternas sino una serie de construcciones y artificios, de múltiples verdades. 
La metaficción historiográfica produce una desnaturalización de la relación temporal entre el presente y el pasado, y genera una intensa autoconciencia del acto de narrar en el presente hechos ausentes del pasado. Son hechos históricos y contemporáneos que permanecen con su duplicidad. Conocer el pasado resulta una cuestión de representar, construir, interpretar.

La metaficción historiográfica resalta la condición propia de la novela, su interdiscursividad, que en este caso es entre el discurso de la historia y el de la literatura.

En el debate teórico se ha puesto énfasis en el carácter textual de los hechos del pasado, se ha hablado de huellas (según Paul Ricoeur, por ejemplo) y también se ha planteado una cuestión hermenéutica, respecto de la interpretación de los hechos discursivizados del pasado. Como consecuencia, la escritura de la historia y de la metaficción historiográfica es una forma intertextual que opera con un archivo de texto abierto a diversas interpretaciones.

Esta propuesta teórica no plantea un problema ontológico del pasado, sino epistemológico, es decir que a los hechos del pasado se les otorga significado, no existencia, al representarlos en la narración.

Para Linda Hutcheon la metaficción historiográfica es un tipo de escritura que responde a una "poética del postmodernismo". Sus argumentos descansan en las siguientes cuestiones:

* Porque el postmodernismo se define como fenómeno cuya modalidad es contradictoria e inevitablemente política, el efecto es subvertir y el modo para hacerlo es la ironía.

* El arte postmoderno no puede ser sino político, al menos en el sentido de sus representaciones, pues aún en lo estético hay una autorreflexividad.

* El foco de interés de la crítica literaria postmoderna es la investigación de la producción social e ideológica del sentido, la política de representación del relato o la imagen.

* La cultura es vista como un efecto de representación y no como una fuente, por lo tanto se plantea una cuestión epistemológica: conocemos el 
mundo a través de una red de significados socialmente establecidos por los discursos de la cultura.

* En este marco, un estudio de la representación es una investigación de los modos en que la estructura narrativa construye una visión del presente y del pasado. Por eso la representación narrativa es histórica pero también y sobre todo política, porque es explicativa, es crítica. La parodia y la ironía son las estrategias más comunes de la metaficción historiográfica.

* En tanto ficción postmoderna este tipo de novelas pone en cuestión las nociones de clausura, totalización y universalidad que constituyen los grandes relatos. No disuelve las contradicciones sino que mantiene la duplicidad.

* La novela postmoderna focaliza desde la autorreflexividad el proceso de producción y de recepción de la paradoja escritura histórica-ficcional. Escribe la forma en que los intertextos de historia, sus documentos o huellas son incorporados en el contexto ficcional, retomando a su vez su valor histórico.

En síntesis, la nueva novela histórica se manifiesta como metaficción historiográfica cuando trabaja para retornar a la crítica histórica y política a través de la metaficción y de la interdiscursividad. Es entonces cuando el lector encuentra un motivo para la lectura: preguntarse acerca de la política de representación narrativa del proceso total de la historia (argentina en este caso) y cómo se construyó una identidad (como noción de sí) en el presente y a partir de una interpretación del pasado.

En cuanto a la manifestación de la nueva novela histórica como novela autobiográfica, nos lleva a desarrollar una revisión de las teorías sobre la autobiografía y sus vinculaciones con el testimonio.

\section{- Testimonio y autobiografía}

Aunque una preocupación central de la crítica ha sido identificar las notas propias del testimonio, aquéllas que constituyen su especificidad, sin embargo 
la definición del testimonio le debe mucho a su relación con otros géneros, tales como la novela y la autobiografía. Es justamente sobre este último aspecto que me interesa detenerme. Trataré en principio de hacer una breve reseña del estudio de la autobiografía con el único objetivo de profundizar sus relaciones con el testimonio.

Al pretender articular mundo, yo y texto, el estudio de la autobiografía no puede ignorar conceptos como historia, poder, sujeto, representación y lenguaje, por lo que se abre una serie de problemáticas teóricas.

James Olney ha señalado tres etapas en el desarrollo de los estudios sobre la autobiografía. En un primer momento, hasta aproximadamente los años cincuenta, se entiende como reconstrucción de una vida, como forma de comprensión de los modos de interpretación de la realidad histórica en que vive el autobiografiado. En 1956 George Gusdorf señala, contra esta historia positivista, que así como no se puede reconstruir el pasado como fue, tampoco la autobiografía puede alcanzar la recreación objetiva del pasado, sino que consiste en una lectura de la experiencia. La escritura da expresión a un ser más interior, es decir que al yo que ha vivido se le añade un segundo yo creado por la escritura.

Para Gusdorf, la autobiografía es un género literario firmemente establecido y representado por los recuerdos de grandes hombres que han encontrado siempre un público atento. Es un género limitado en el tiempo y en el espacio, pues su punto de referencia inicial son las Confesiones de San Agustín, y por otra parte es una manifestación propia de la cultura occidental que luego ha comunicado a otras civilizaciones.

El autor de una autobiografía se considera el centro de un espacio vital, da a su imagen una existencia independiente e irremplazable. Esta toma de conciencia de la originalidad de cada vida es, según dice Gusdorf, producto tardío de cierta civilización, cuyas presuposiciones son: la humildad ha entrado en la historia; la historia quiere ser la memoria; cada hombre es importante para el mundo y enriquece el patrimonio común de la cultura.

La aparición de la autobiografía supone una nueva revolución espiritual: el artista y el modelo coinciden. El interés se ha desplazado de la historia pública a la historia privada. La autobiografía exige que el hombre se sitúe a cierta 
distancia de sí mismo; a fin de reconstituirse en su unidad y en su identidad a través del tiempo, que trate de lograr una expresión coherente y total de todo su destino.

La intención y privilegio de la autobiografía como género literario es ser uno de los medios del conocimiento del sí mismo gracias al desciframiento de una vida en su conjunto. En otras palabras, es una segunda lectura de la experiencia, que mediatizada por la memoria, le concede perspectiva al narrador. No consiste en una simple recuperación del pasado tal como fue, pues la evocación de un mundo ido para siempre no revela más que una figura desnaturalizada. La recapitulación de esa experiencia basta para modificar su significado.

La narración le da sentido al acontecimiento del pasado desde un presente que inevitablemente conoce el futuro, la continuación de la historia que cuenta. Esta postulación del sentido determina los olvidos y las deformaciones de la memoria provienen de allí, de un escritor que recuerda y quiere hacer prevalecer determinada versión de su pasado.

De este modo se traslada el énfasis de la teoría a la cuestión del yo y surge entonces una segunda etapa en los estudios sobre la autobiografía, centrada en la conexión entre texto y sujeto. El problema principal consistirá en ver de qué manera un texto representa a un sujeto, por lo tanto la memoria ya no sería un mecanismo de mera grabación de recuerdos sino un elemento activo que reelabora los hechos.

Consecuentemente se origina un cambio en los roles del autor y del lector. El autor pasa de ser un testigo fidedigno a ser un ente en busca de una identidad, y el lector por su parte deja de ser comprobador de la verdad para convertirse en intérprete.

A esta etapa podemos adscribir un trabajo tan conocido como el de Philippe Lejeune y su concepto de "pacto autobiográfico". Su definición abarca un período de dos siglos de la literatura europea y textualmente parte de la posición del lector, que es en definitiva quien hace funcionar los textos. La autobiografía es para Lejeune un "relato retrospectivo en prosa que una persona real hace de su propia existencia, poniendo énfasis en su vida individual y en particular en la historia de su personalidad". ${ }^{45}$ 
Para que haya autobiografía es necesario que coincidan la identidad del autor, la del narrador y la del personaje. Esta identidad suscita numerosos problemas: ¿Cómo se expresa la identidad del narrador y del personaje en el texto?; ¿cómo se manifiesta la identidad del autor y la del personaje-narrador?, caso en que se opone la autobiografía a la novela; y ¿no se confunden identidad con parecido?, dilema en que se oponen biografía y autobiografía.

Lejeune responde a la primera cuestión sosteniendo que en la autobiografía clásica la identidad del narrador y del personaje principal queda indicada por el uso de la primera persona. Sin embargo, hay otros casos que obligan a disociar la identidad de persona, como por ejemplo la autobiografía en segunda o en tercera persona.

Por otra parte, el problema de la autobiografía debe situarse en relación al nombre propio. En el nombre de la portada del libro se resume la existencia del autor, que por una convención social va unido a una persona real cuya existencia quede fuera de duda para el lector. Lejeune afirma que "a caballo entre lo extratextual y el texto el autor es la línea de contacto entre ambos". ${ }^{46}$ El autor es un nombre de persona que asume una serie de textos publicados y obtiene su realidad de esa lista de obras.

En cuanto a la relación identidad-parecido, Lejeune plantea que la autobiografía supone siempre y en primer lugar una identidad asumida a nivel de la enunciación y un parecido a nivel del enunciado.

Al tratar de definir la autobiografía se tropieza con las discusiones clásicas que suscita el género: relaciones entre biografía y autobiografía, al igual que entre novela y autobiografía.

Aquellos textos en los que el lector puede tener razones para pensar en una coincidencia entre la historia del personaje y del autor, pero no está asumida la identidad, son consideradas novelas autobiográficas por Lejeune. Estas se definen por su contenido e implican gradaciones. Mientras tanto, la autobiografía no conlleva gradaciones, o lo es o no lo es.

No obstante, las diferencias no están dadas por el análisis interno del texto, pues la novela puede imitar todos los procedimientos de la autobiografía, sino por un pacto novelesco que tiene dos rasgos: práctica patente de la no 
identidad (autor-personaje) y atestación de la ficción (subtítulo "novela" en la portada)

El pacto autobiográfico es la afirmación de la identidad del autor-narradorpersonaje y envía al nombre de la portada. Las formas del pacto autobiográfico son muy variadas, pero todas ellas remiten a la firma. Las maneras en que se establece el pacto pueden ser implícitas en los títulos o en el prólogo y explícita en la coincidencia del nombre de narrador-personaje con el del autor de la portada.

En cuanto a la relación biografía-autobiografía, Philippe Lejeune sostiene que ambos son textos referenciados, que se someten a una prueba de verificación. Su fin es el parecido a lo real. Pero mientras la autobiografía se sostiene por la identidad, la biografía se sustenta sobre el parecido como un horizonte imposible, entre el personaje (textual) y el modelo (extratextual).

Plantea finalmente este autor que no se trata de saber si es más verdadera la autobiografía o la novela sino que resulta revelador que ambas categorías de textos se inscriben en un "espacio autobiográfico" creado por el lector.

Nicolás Rosa ${ }^{47}$ señala, ante la propuesta de Lejeune, que se trata de un contrato aleatorio no consensual, que presupone la existencia de un imaginario social y un régimen de intercambio de valores simbólicos. Sería un contrato donde el juego imaginario de la simulación del sujeto estaría sostenido sobre las leyes simbólicas del simulacro. Como consecuencia, los problemas de fidelidad y autenticidad deben ser resueltos por el lector.

En esta perspectiva, los contratos de lectura son pensados como contrato de intercambio, y según Rosa todo contrato de lectura nace fallado, es aleatorio porque el sujeto de la escritura propone y el de la lectura acepta, disiente, polemiza. El otro textual recupera sus derechos cuando provoca en el lector el recuerdo de los textos que lo precedieron. En la frontera del pasado, leído y escrito, y el futuro, por escribir, se forman los imaginarios colectivos.

La escritura autobiográfica, afirma Rosa, implica un acto autobiográfico que genera una temporalidad fundada sobre la memoria, el recuerdo, el olvido, sobre los procesos de memorización y rememorización. El acto se instaura cuando el yo escribe su biografía. "Yo se escribe a sí mismo como otro". ${ }^{48} \mathrm{La}$ 
memoria de la autobiografía, al mismo tiempo que recuerda, oscila entre el recuerdo encubridor y el deseo de saber, cuando rememora comienza a olvidar. El olvido es la condición indispensable para que la memoria se revele en el recuerdo y transforme la identidad de aquél a quien se revela en el olvido.

En los autores que he mencionado hasta aquí podemos detectar un rasgo común: su preocupación por justificar la capacidad cognoscitiva de la autobiografía.

En los ochenta se desarrollará una tercera etapa en los estudios sobre la autobiografía, cuyo centro será el problema del lenguaje y del sujeto. Éste será precisamente el tema central planteado por Paul de Man, quien afirma que la autobiografía no se distingue por proporcionarnos conocimiento sobre un sujeto que cuenta su vida sino por su peculiar estructura en la que dos sujetos se reflejan y se constituyen mutuamente.

Paul de Man plantea dos intentos de circunscribir la autobiografía: uno, dado por su designación como género literario, y el otro por la distinción entre autobiografía y ficción.

En relación con la primera cuestión, el autor sostiene que la autobiografía no es un género sino una figura de lectura y entendimiento que se da en todo texto. La estructura especular de la autobiografía supone un intercambio que constituye al sujeto. El interés de la autobiografía no radica en que ofrezca un conocimiento veraz de uno mismo sino en que demuestra la imposibilidad de totalización de cualquier sistema textual. Las autobiografías, a través de su insistencia en el nombre propio, la memoria y en la doblez de la especularidad declaran su constitución cognitiva y tropológica, pero se muestran ansiosas de escapar a ese sistema. La figura dominante en el discurso autobiográfico es la prosopopeya.

A partir de esta reseña teórica se puede sintetizar que los estudios sobre la autobiografía se han planteado en torno a las siguientes cuestiones: las posiciones relacionadas con el yo, la localización de la ficción y su condición como género literario en relación con la biografía y la novela.

Cuando se trata de determinar las posiciones relativas al yo y al lenguaje en el orden del ser, los estudiosos se alinean en forma diversa; no obstante, coinciden en localizar la ficción en el lenguaje que se sitúa frente al mundo. 
Para explorar esta problemática agregaré otros a los autores que ya hemos abordado.

Se ha postulado que el lector distingue una autobiografía de otros tipos de textos porque ésta establece una identidad explícita entre autor-narradorpersonaje Paul de Man, en el ensayo mencionado, ataca esta postura planteando que "la autobiografía pertenece a un modo más simple de referencialidad" y que "parece depender de hechos reales y potencialmente verificables de una manera menos ambivalente que la ficción”. Según este autor, la aspiración de la autobiografía de moverse más allá de su propio texto hacia un conocimiento del yo y su mundo se funda en la ilusión producida por la estructura retórica del lenguaje. Despojada de la ilusión de la referencia, la autobiografía vuelve a inscribirse en la cárcel del lenguaje.

James Olney, por su parte, propone una perspectiva radicalmente diferente de la representación retórica del yo en la autobiografía. Olney escribe: "El hombre explora el universo continuamente en busca de leyes y formas que no sean de su propia creación, pero lo que finalmente encuentra siempre es su propia cara: una especie de omnipresente...que, si quiere, puede reconocer como propia su imagen en el espejo". Para Olney el tropo dominante de la autobiografía es la metáfora, que permite que tanto el autor como el lector se muevan hacia el conocimiento del yo. Juzgar el estatus ontológico del yo está fuera de lugar pues "el yo se expresa a sí mismo mediante las metáforas que él crea y proyecta, y lo conocemos a través de estas metáforas; pero que no existió como existe ahora y como es ahora antes de crear sus metáforas". ${ }^{4}$

El punto de vista de Paul de Man sobre el discurso de la autobiografía contradice la concepción tradicional, que la concibe como autoconocimiento y autodescubrimiento. Según él, la balanza del poder en la relación entre el yo y el lenguaje decanta hacia el lado del lenguaje: el escritor es como fue escrito por el discurso que lo utiliza, el yo es desplazado por el texto.

Mientras tanto, para Olney el lenguaje es un instrumento de posibilidad para ser puesto al servicio de la autodefinición. El yo, como lo conocemos en la autobiografía, se convierte en un ser a través del lenguaje.

Vale la pena hacer notar que si bien la práctica de escribir autobiografía no va a resolver la cuestión ontológica de la prioridad del yo o del lenguaje en 
el orden del ser, sí tiende a llevar a los autobiógrafos a entender el yo como producto de la autoinvención. ¿Cuáles son los orígenes de la idea del yo que la escritura y la lectura de la autobiografía presuponen?

Los modelos culturales de la personalidad humana determinaron la historia del yo como idea. Los historiadores de la autobiografía, como Gusdorf, ya lo habían anunciado. Como se dijera anteriormente, su propuesta es que la autobiografía no es un fenómeno universal, y que el conocimiento de cada individuo que asume la autobiografía, es producto de una civilización. Destaca que la aparición de la autobiografía está enlazada con el cambio espiritual del hombre que ingresó en la historia y reconoce en el hablar de sí mismo que el presente difiere del pasado y que no se repetirá en el futuro.

Sin embargo, nadie ha explorado la relación entre el yo y el lenguaje en la autobiografía con mayor perspicacia que Elizabeth Bruss, ${ }^{50}$ que identifica el yo y la autobiografía como estructuras lingüísticas homólogas y aboga por un acercamiento a la autobiografía desde la teoría de los actos de habla. En ese marco propone que es tarea de la crítica trabajar con claves textuales para reconstruir el contexto del habla original y conseguir acceso al mundo privado del autobiógrafo.

Si se acepta la escritura de la autobiografía como una especie de habla y se postula que la intención de un texto de ese carácter es comunicar la naturaleza del yo del autor, entonces puede aceptarse también que la autobiografía, como el habla, proporcione un medio para aprehender el yo en su presencia viva.

Otro camino de investigación es el propuesto por Jacques Derrida. En su opinión no basta una línea clara y divisible entre vida y obra; tampoco es posible explicar a una por medio de la otra, sino que hay que pensar lo autobiográfico desde la premisa del borde paradójico que las separa y atraviesa el cuerpo y el corpus del autor. La estructura de la firma hace que esté presente el destinatario. El yo pasa siempre por el otro. Así, lo autobiográfico se convierte en heterobiográfico.

En lo referente a la cuestión del género, el crítico argentino Nicolás Rosa sostiene que la autobiografía ocupa un lugar de descentramiento potable. Como marca de una escritura que se asienta sobre el pronombre en primera 
persona, siempre itinerante entre los géneros memorialísticos y/o ficcionales, apareció entre el discurso de la historia (por su efecto memorialístico, su relación con un cierto pasado y por su ficción de credibilidad) y el discurso del sujeto, por el espacio egocéntrico que parecía instaurar.

Sólo a partir del siglo XVIII la autobiografía pudo reclamar un estatuto, siempre incierto. Esta incertidumbre genérica es para muchos críticos sustancial y formal, pero para Rosa es contingente, insustancial e informal, y nace del juego íntimo de la autobiografía que potenciando el yo no hace creer, simula que la ficción se ausenta de su discurso y que aquello que el yo cuenta está invariablemente sometido a la refutabilidad dada por la verificación de la existencia del autor y la existencia (real o no) de los hechos que se cuentan. En el régimen de certeza-incertidumbre que genera todo relato, la autobiografía simula que todo lo narrado es todo lo acontecido. Este efecto vincula la autobiografía con la historia como discurso en donde lo narrado y lo acontecido no reconocen el valor constituyente de la verdad textual que siempre interfiere, y no refiere, entre la verdad de lo que se relata y la verdad de lo acontecido.

La escritura es puro presente de lectura/escritura. Afirma Rosa que "la literatura autobiográfica es aquella parte de la literatura...que no osa decir su nombre desde la perspectiva del género...no es posible determinar si preside el género -la literatura del yo-, lo comparte o se subordina a las memorias, las confesiones, el diario íntimo, la biografía, los recuerdos de, y más lejanamente la novela biográfica y la novela en primera persona". ${ }^{51}$

Rosa se refiere luego a Mijail Bajtin para sostener que su aporte fundamental a esta problemática es no establecer una separación entre biografía y autobiografía. En términos de valores, la autobiografía siempre tiende a realizar un valor eminentemente bio-gráfico.

Para Bajtin, la forma biográfica puede ser autobiográfica cuando es posible la coincidencia entre el héroe y el autor, o más exactamente desde el punto de vista de un carácter particular del autor con respecto al héroe. "Un valor biográfico no sólo puede organizar una narración sobre la vida del otro sino que también ordena la vivencia de la vida misma y la narración de la propia vida de uno; este valor puede ser la forma de comprensión, visión y expresión de la vida propia". ${ }^{52}$ 
Es necesario señalar la importancia que Bajtin le otorga a la memoria y al tiempo en el escrito autobiográfico: "Un recuerdo tranquilo acerca de un pasado lejano de uno se estetiza y se aproxima formalmente en una narración...Todo recuerdo del pasado es un poco estetizado, mientras que el recuerdo del futuro siempre es moral". 53

En nuestros recuerdos habituales acerca del pasado, con frecuencia es el otro quien viene a ser el activo y es en su tono valorativo como nos recordamos. Yo me percibo valorativamente dentro de una colectividad: la familia, la nación, la humanidad. En este caso la postura del otro hacia mí goza de autoridad. Mi contemplación de mi propia vida es la anticipación del recuerdo de otros acerca de esta vida. Así es como el narrador se convierte en héroe: yo soy el narrador de mi vida por medio de sus otros héroes.

Son posibles dos tipos de conciencia biográfica valorativa: la aventura heroica y la cotidianidad social.

En la base del valor biográfico de la aventura heroica están la voluntad de ser héroe, de tener importancia en el mundo de los otros (la gloria); la voluntad de ser amado (el amor) y la voluntad de vivenciar la aventura de la vida (el fabulismo). Estos tres valores son estéticos y organizan también la representación artística de su vida por el autor.

En cuanto al segundo tipo, no hay historia en tanto fuerza organizada de la vida: la humanidad de los otros en la vida del héroe es la humanidad de los vivos y no de los héroes muertos. El centro valorativo ya no son los valores culturales e históricos sino los sociales y familiares. No se trata de la gloria sino de la buena fama. El amor no se vincula a la gloria sino a los otros. La actividad del narrador-protagonista es la observación y la narración.

La creación del autor no es acto sino Ser. Se da el encuentro de dos conciencias pero las dos están de acuerdo y sus mundos valorativos coinciden. La finalidad de la biografía cuenta con un lector familiar que participa en un mismo mundo de la otredad: este lector ocupa la posición del autor.

Desde otro enfoque, Käte Hamburger propone una distinción de la autobiografía y la novela autobiográfica fundada sobre la existencia de un sistema lógico de la literatura. La narración en primera persona tiene su origen esencial en la estructura enunciativa autobiográfica. Esta inclusión, según 
Hamburger, "aclara su originario carácter autobiográfico y descubre en qué se funda el carácter literario que la distingue de la auténtica autobiografía" ${ }^{54}$

La narración en primera persona, por su naturaleza, se presenta a sí misma como documento histórico, sobre todo por el peculiar concepto de yo que genera, en tanto sujeto enunciativo. Su posición lógica es definida por su carácter de fingida enunciación de realidad, cuya ley es la unidad de perspectiva o punto de vista y cuya consecuencia es que los personajes que aparecen sólo lo hacen en relación al yo narrador.

En la novela autobiográfica el escritor vuelve la vista atrás desde un presente fijo a la totalidad de su vida pasada. Como consecuencia, ese yo de origen no se modifica, permanece inmóvil. De esta afirmación se desprenden dos elementos estructurantes: por un lado, ese yo fijo, al reproducir su vida pasada, procede igual que una auténtica autobiografía. Por otra parte, significa que vive dos etapas bien separadas, la de su pasado y la de su vida actual. En estos aspectos, no difiere la ficción del relato factual.

Sin embargo, se plantea un fenómeno paradójico: la identidad entre el yo objetivado de una etapa anterior y el actual no siempre se viven con la misma intensidad sino que aquél puede llegar a vivirse como una persona independiente, que, separada del narrador, pasa a ser entonces un personaje más. De modo que la enunciación de realidad retrocede. Al mirar su vida, el narrador capta un mundo histórico y geográfico, toda una época que se presenta como algo "muerto", como todo pasado.

En estos dos elementos relacionados entre sí por la mirada retrospectiva radica la posibilidad de que la narración en primera persona abandone la enunciación de realidad para desarrollarse como ficción.

La forma enunciativa marca los límites entre narración en primera persona y ficción. En efecto, se trata de una enunciación de realidad pero fingida. Es la forma y no el contenido de realidad lo que le permite presentarse como forma literaria variable, como fingida enunciación de realidad.

Se trata, pues, de una mímesis de enunciación de realidad: la primera persona habla de sí misma, pero no pretende contar el mundo como vivencia de un yo sino como realidad independiente que afronta el sujeto. Con estas condiciones la narración en primera persona viene a encajar en el sistema 
lógico estructural de la literatura y traspasa el límite entre ficción y enunciación de realidad.

Ante estas consideraciones surge una pregunta: ¿Cuál es la relación que se ha establecido entre el testimonio y la autobiografía?

Las propuestas críticas que insisten en una identidad no novelística, no ficcional del testimonio, enfatizan sus diferencias con la autobiografía.

Fredric Jameson identifica a la autobiografía como el género propio del Primer Mundo. Es la forma esencial en la que el llamado "sujeto centrado" ha sido construido por la cultura occidental. Así es que la presenta como una zona de formación de la personalidad o ego, de la emergencia del sujeto y también como una ocasión para el desarrollo de la experiencia de la memoria en relación privilegiada con el tiempo. Para Jameson, la autobiografía construye al sujeto personal y la ilusión de una identidad subjetiva, personal y privada. Sostiene también que el Tercer Mundo ha desplazado la tradición burguesa mediante la despersonalización o el anonimato y la espacialización; lo que el post-estructuralismo denomina "sujeto descentrado". Entiende anonimato no como ausencia sino como multiplicación del nombre, afirmando un criterio a la vez literario y social, pues ofrece una nueva idea de la colectividad, y un concepto específico de la cultura y experiencia del Tercer Mundo. Estas condiciones tienen relación significativa con el testimonio.

Por su parte, John Beverly centra la diferencia entre testimonio y autobiografía por la afirmación del sujeto individual como rasgo común a ambas, pero siempre vinculado con una situación de clase de marginación, opresión y lucha en el primer caso. Si se pierde esta conexión el testimonio se convierte en autobiografía. Quizá su aporte más interesante al respecto es afirmar que producen un efecto diferente sobre el lector. El discurso autobiográfico genera en el lector el efecto de considerarse un integrante de la burguesía y confirma un cierto privilegio social. El testimonio, por el contrario, significa la necesidad de un cambio social en el cual la estabilidad del mundo del lector se pone en cuestión.

La literatura argentina ofrece ejemplos que plantean la posibilidad de problematizar al testimonio como género, al ubicarlo en las fronteras con la 
autobiografía. Tal es el caso de la obra La memoria en donde ardía, de Miguel Bonasso.

Desde el concepto de Beverly así sería, pues se trata de un narrador de la burguesía, es la voz de un sujeto desfavorecido sin duda, pero su subalternidad no responde a los términos clasistas conque delimita Beverly esta condición.

Entonces es posible preguntarse: ¿Cuándo la autobiografía se convierte en testimonio? Mi hipótesis es que esta voz representa a otras. Tiene un alcance social (el de las Madres de Plaza de Mayo, por ejemplo, o el de todos aquellos que sufrieron el exilio, la "desterritorialización"); la historia es ejemplarizante en lo público para contar la "historia otra", de modo que parto de la idea de que lo testimonial se apoya sobre la identidad del sujeto narrador y sobre su objeto pragmático.

En lo básico que cuenta, para citar nuevamente a Jameson, estamos ante un "sujeto descentrado". Tal vez lo que está faltando es una definición de la subalternidad que abarque la situación de países como la Argentina, que han sufrido otro tipo de marginación y opresión, la de los golpes militares, y por tanto se encuentran con otra categoría de persona, el "desaparecido", y otra necesidad de lucha, la de la justicia.

El análisis del corpus se propone probar esta hipótesis y aún desarrollarla.

\section{IV - El testimonio en la Argentina}

\section{Sus antecedentes}

La crítica sobre el testimonio latinoamericano ha realizado una aproximación genealógica que enumera frecuentemente los antecedentes con diversos criterios metodológicos. Considero importante el aporte de algunos autores que señalan el origen del relato testimonial en las crónicas de la Conquista que ingresan desde la formación discursiva historiográfica a la literatura. ¿Cómo se ha producido esta transposición?. Para dar respuesta a esta cuestión es necesario señalar las diferencias entre criterios de tipología textual que atienden al contexto de producción de las crónicas y otros que destacan la importancia del contexto de recepción. En cuanto al primero, cabe destacar los presupuestos epistemológicos que orientan la escritura de los 
textos: la manera en que se concibe el criterio de verdad durante los siglos $\mathrm{XVI}$ y XVII, como pauta sustancial para la formación discursiva historiográfica.

Como medida para valorar la verdad se consideran tres actitudes de los escritores: los que tienen acceso directo a la información como testigos presenciales o agentes de los acontecimientos; los que se basan en informaciones indirectas inmediatas, relatando con posterioridad a los acontecimientos vividos, y la de los que se basan en documentos.

Todos abordaron el tema sin fuentes clásicas de apoyo, pues la base del conocimiento historiográfico, de su valor de verdad y sustento de la crónica, es la experiencia. Es sustancial el cambio que se produce en la concepción del saber: al conocimiento se accede no sólo por lo almacenado sino por mediación de la experiencia. El criterio de verdad está asociado a lo pragmático.

En tanto, en la década del sesenta se produce la irrupción de un nuevo género con la publicación de $A$ sangre fría de Truman Capote (1966), consagrado como new journalism por Tom Wolfe, Norman Mailer y el mismo Capote. Las causas de este surgimiento se atribuyen al desarrollo de los medios de comunicación masivos y al vertiginoso ritmo de los cambios sociales en Estados Unidos, lo que produjo una gran insatisfacción con la práctica del periodismo tradicional.

El new journalism implica la difusión de estrategias periodísticas diferentes, como la deliberada subjetividad del reportero en la narración de su versión de los hechos, el empleo de recursos propios de la ficción narrativa, la actitud crítica frente a los medios. Los críticos norteamericanos han considerado como ejemplo modélico del new journalism a Operación masacre de Rodolfo Walsh (1956), lo que implica ubicar al testimonio latinoamericano bajo ese rótulo. Frente a esta clasificación, Elzbieta Sklodowska plantea que por un lado es justificable, en virtud de la competencia del lector que se funda sobre la literatura preexistente, pero por otro lado afirma que no han sido registradas las diferencias de producción y recepción de los textos concretos.

Sin embargo, el hito más significativo para el testimonio latinoamericano es su institucionalización en 1970 cuando Casa de las Américas incorpora esta 
categoría en sus concursos literarios. Surge, consecuentemente, una pregunta: ¿Por qué sucedió en los años setenta?

Alfredo Alzugarat ${ }^{55}$ destaca algunas condiciones entre la multiplicidad de factores:

La proliferación de discursos narrativos que surgen como consecuencia de la extensión de la lucha guerrillera en casi todos los países de América siguiendo las directivas de la revolución cubana y del impacto del Diario del Che, que adquirió valor paradigmático.

Los textos que responden a la realidad de una América en crisis, polarizada social y económicamente, donde el cuestionamiento al poder de las minorías lleva implícito el desarrollo de las fuerzas represivas y de nuevos mecanismos de represión.

La lucha de resistencia a través del discurso, efectuada por sectores marginados y silenciados.

La asimilación por parte de la literatura de los nuevos cauces de la investigación antropológica a través de Barnet.

La constatación del fenómeno de la otredad.

El desarrollo del revisionismo histórico.

La renovación de las orientaciones de la Iglesia Católica.

Es digno de señalar que en esa oportunidad formó parte del jurado del Premio Casa de las Américas el propio Rodolfo Walsh ${ }^{56}$, quien ya había inaugurado el género en la Argentina, como se ha dicho. Vale recordar que se trata de un narrador de ficciones, escritor, periodista y un hombre de acción que produce literatura política.

En 1956, Walsh se había conectado con un obrero de la construcción sobreviviente de la matanza de José León Suárez y a través de él comenzó a trabajar sobre el libro que sería señero en el periodismo y en la literatura política. Walsh publica lo que se conocería luego como Operación masacre en el semanario Propósitos, de Leónidas Barletta. Otras notas aparecieron en Revolución Nacional, pero fue en Mayoría donde la serie adquiere su formato más prometedor. 
La obra de Walsh adhiere al canon del género policial, pero recupera de los relatos testimoniales la subjetivación, un procedimiento que lo diferencia del periodismo y lo introduce en la narrativa ficcional. Su aparición produjo una renovación de los géneros en el campo literario argentino. Lo periodístico y lo policial eran consideradas formas marginales que ingresan al estatuto literario al dar origen a la "no ficción" de Walsh. Ambos se retroalimentan para producir una nueva forma, cuyo eje organizador es la búsqueda de la verdad o la reflexión en torno de ella. La denuncia está centrada, más que en la descripción del delito, en la imposibilidad jurídica o legal de repararlo. En tanto el tema esencial es la justicia, Walsh representa al periodismo de investigación. El alto valor documental aproxima su narrativa al principio de verdad y a la denuncia, pues su aspiración es contrarrestar con testimonios marginales la versión oficial de los hechos.

Operación masacre focaliza, además, al responsable: el Estado. En efecto, los roles víctima-victimario se invierten y el texto alcanza así su politización, con lo que se reafirma el poder de la escritura contestataria. En rigor, esta condición del relato lo encauza hacia la tradición de la novela política argentina, que, aunque extensa y discontinua, tiene su origen en Roberto Arlt y vínculos con sus herederos: David Viñas y Ricardo Piglia. ${ }^{57}$

Sklodowska señala una diferencia importante entre Walsh y los discursos testimoniales como el de Barnet o Rigoberta Menchú. Dice al respecto que "aquí la conciencia subalterna no está privilegiada per se como fuente de la verdad única, se trata siempre de verdades parciales". ${ }^{58}$ Por otra parte, no se borran las huellas de su propio proceso de escritura ni la interacción narradortestigo.

En Operación masacre la función poética convive en tensión con la función pragmática comunicativa y pese a la fuerza de su dimensión documental ha sido leída como novela. La importancia de la obra de Walsh la convierte en el referente natural al que debería remitirse todo análisis del relato testimonial en la Argentina. No escapa a esa consigna este trabajo; por lo tanto, será objeto de reflexión crítica siempre que el corpus lo demande.

\section{El fin de siglo: Memoria de la violencia}


La expresión "fin de siglo" adquiere aquí el significado propuesto por Frank Kermode ${ }^{59}$ : una época de crisis entendida como elemento central para encontrar sentido al mundo, como una manera de pensar el presente.

Beatriz Sarlo, por su parte, lo define como “...un teatro donde la cronología monta su espectáculo de conclusión y apertura. Solidificaciones del tiempo histórico, fines y comienzos son momentos a los que se adjudica mayor densidad porque, efectivamente, tienen mayor peso simbólico. Las promesas del futuro muestran su lado incierto cuando aparecen en un 'fin de siglo', contagiadas por la sensación nostálgica de un cierre de época. Y al revés, el fin de siglo abre una rajadura que interrumpe la sucesión menos perceptible de las décadas". ${ }^{60}$

No es posible referirse al tema sin mencionar la conceptualización que propone Josefina Ludmer. ${ }^{61}$ Esta investigadora define al fin de siglo como un "entre", un proceso que genera relatos e historias. Se trata de un ciclo en sí mismo, signado por la internacionalización de la economía y la tecnología masiva, que transforman los discursos de la cultura.

Me interesa destacar una idea fuerza común a estas definiciones: la memoria recupera el pasado y crea un horizonte de sentido en el presente para una comunidad de lectores, con anclaje en un espacio y un tiempo. En rigor, el relato testimonial de fin de siglo en la Argentina discursiviza la memoria, y en tanto práctica política conlleva recuerdos y olvidos en torno de un núcleo problemático: la violencia de la década del setenta.

El diálogo intersubjetivo de la memoria individual, propia del relato testimonial, construye la memoria colectiva; plural y dividida, se vuelve sobre el pasado, al margen de la historia, desde el campo de la literatura, para resignificarlo en función de las necesidades de la sociedad. En este enunciado se esbozan dos cuestiones que entiendo merecen otra dimensión de análisis:

La violencia como eje temático organizador del relato testimonial y sus implicancias: la relación literatura-política y literatura-historia.

Las condiciones culturales y políticas que generan el auge de producción y recepción del relato testimonial en este fin de siglo. 
En cuanto al primer enunciado, creo pertinente recordar que la violencia estatal en la Argentina surge del modelo complejo de relaciones sociales y de su dependencia económica que aplica al interior de las naciones la relación centro-periferia, por lo tanto la historia se ve expuesta a una alternancia democracia-dictadura, al punto de que es posible hacer una periodización en ciclos caracterizados por el régimen del Estado y la relación del ciudadano con el cuerpo político.

A partir de este concepto, el llamado "segundo período burocrático" (19761983) representa un hito en la memoria del país. En el campo cultural se puede hablar de un antes, durante y después de esa dictadura. El golpe militar de 1976 significó una ruptura de las redes sociales y evidenció una profunda crisis de la ciudadanía. El territorio nacional sufrió una clausura homogeneizante y la desmovilización a partir de la "cultura del miedo" y la "desterritorialización" del sujeto.

En este marco, surgió un foco de resistencia diferente: el de las Madres de Plaza de Mayo. Con ellas se configura una nueva realidad discursiva cuyas características sustantivas son las siguientes:

Representa la "otredad".

Vincula el lenguaje a la pragmática, el decir al hacer.

Introduce un nuevo significante de la resistencia: el silencio y el cuerpo.

Desplaza los significados de la violencia a los desaparecidos e instala el problema en el campo de la ética.

Mantiene en el presente la "memoria viva" ${ }^{62}$

Por otra parte, el campo literario fue uno de los lugares donde los discursos autoritarios impusieron sus valores. La literatura y la crítica estuvieron a su servicio, en la mayoría de los casos. ${ }^{63}$ Sin embargo, una voz minoritaria subvirtió los canales oficiales. Desde la marginalidad, el discurso simbólico contestó a la autoridad del Estado, mantuvo viva la conciencia y nucleó a un grupo de intelectuales. Se unió a la resistencia, pero, no obstante ello, no llegó al público común. ${ }^{64}$

La década del ochenta está signada por un gesto cultural de aceptación del orden de las cosas e implantación del discurso del olvido. Gran parte de los 
intelectuales no asumieron un riesgo: el de la repercusión de sus palabras y de sus silencios sobre la gente. En verdad, el discurso literario de los ochenta, con excepciones notables como Respiración artificial, de Ricardo Piglia, no enfrentó el análisis profundo de la "desterritorialización" de los sujetos, dejando así un profundo vacío en la reflexión: los "desaparecidos".

Es el "fin de siglo" el que empieza a producir en la Argentina la llamada "nueva novela histórica" (cuyas características he desarrollado en el apartado anterior), en tanto marco discursivo y cultural más amplio en que se ubica la novela testimonial, como una de las variantes de sus modos de decir. (Ver en el Anexo mi entrevista con John Beverly).

Señalaré al respecto algunas cuestiones que entiendo son cualitativamente significativas para el estudio de la literatura argentina. En primer lugar, la crítica coincide en que es muy fuerte la tradición que vincula la novela a la política; en la historia de la literatura argentina esta relación se inicia en el siglo XIX. Pero lo que llamamos "nueva novela histórica" se enmarca en un concepto más abarcador, el de la relación literatura-historia. La pregunta de fondo planteada por esta relación es la del sentido, la de la posibilidad misma del conocimiento. La novela es una explicación del discurso de los hechos del pasado.

Justamente en la novela histórica pueden identificarse un referente y un referido. Uno y otro son construidos por la escritura, a partir de un procedimiento previo de deconstrucción y de operaciones complementarias: la investigación y la selección en función de un efecto de lectura. La consecuencia inmediata es que se incorpora un nuevo eje de discusión que da cuenta de la existencia de un campo de ficción desde el que se busca una explicación del pasado reciente por su impacto de sentido sobre el presente.

Por otra parte, la escritura se gesta en una interdependencia entre la estética y la ética. Se orienta en un horizonte de expectativa cuya preocupación es la correspondencia responsabilidad-acción ante la violencia de los setenta, no asumida ni cuestionada en profundidad; la dicotomía entre responsabilidad moral y responsabilidad legal, conflicto aún no resuelto en la sociedad. Así y todo, las producciones culturales de las décadas del setenta y del ochenta han generado un movimiento de apertura. 
El fin de siglo reclama un orden. En la configuración del pasado está presente la expectativa del lector: encontrar la totalidad, el cierre; se trata del paso del fin inminente al fin inmanente. ${ }^{65}$

En virtud de estas consideraciones se puede afirmar que el relato testimonial ocupa el lugar de la historia crítica. Para salir de la relación con el pasado es necesario el olvido. El olvido es una fuerza que permite crecer, pero sólo es posible si pasa por la instancia de la denuncia del abuso y el enjuiciamiento. Más que la verdad del testimonio importa la fuerza de la justicia que capture el pasado, sostenido en el presente con proyección al futuro. La ficción conserva huellas del mundo práctico y del discurso histórico pero reorienta la mirada en busca de una respuesta ética-estética.

A estas razones se agrega otro aspecto relevante para comprender el auge del relato testimonial. Es posible también explicar la vigencia del relato testimonial con motivos esencialistas que destacan las cualidades propias del género, tales como la vocación para la comunicación directa de acontecimientos que pertenecen al pasado y que son socialmente significativos, y el espacio que, consecuentemente, ocupa en el ámbito público y que la historia académica ha dejado vacío.

Otro factor importante es que se trata de un fenómeno complejo en tanto se ubica en el cruce entre el escenario de la comunicación social y el proceso de producción de sentido histórico, mediante la recuperación de la memoria colectiva. Sin embargo, es inherente a los rasgos enunciados la búsqueda de las causas del auge de este género en la relación literatura-sociedad.

Este principio de análisis reclama la reconstrucción de la lógica del campo intelectual. Pueden identificarse en su estructura escritores consagrados como agentes del campo literario y otros que provienen de distintos sectores: escritores-periodistas, escritores-periodistas-militantes, escritores-protagonistas o testigos de los acontecimientos de la década del setenta. Todos vinculados a un campo de poder que se presenta como una compleja trama en la que interviene el poder político, el de la opinión pública, el de las Instituciones y el poder económico. Coincido con Beatriz Sarlo cuando afirma que "la nueva lógica comunicacional, aún cuando parezca no ocuparse de ello, impugna las formas artísticas que conocemos, porque la expansión de los medios 
audiovisuales afecta, al mismo tiempo, el lugar del arte y el de los intelectuales". 66

Se identifica como determinante para la producción y recepción de la novela testimonial la presencia superlativa del periodismo y en especial del diario Página/12 desde su aparición en 1987. Apreciado inmediatamente como un cotidiano distinto, cumplió una función renovadora por su estilo, un lenguaje más directo y coloquial, y por su audacia para tratar temas sobre grupos minoritarios y marginales, forzando los límites de lo que "se podía" decir. Su política explícita fue el pluralismo, el debate y el fuerte compromiso con la democracia. Llama la atención, justamente, que el procedimiento predominante de sus notas sea la investigación exhaustiva y la denuncia. Así, nucleó a periodistas-escritores que transformaron sus investigaciones en libros y cruzaron la frontera entre la literatura y la historia.

Es necesario destacar que los medios de comunicación social cumplen un rol relevante como facilitadores del acercamiento autor-lector e instalan la discusión y la crítica en la esfera pública. Constituyen un órgano democratizador del conocimiento sobre las producciones culturales, pero también en un importante orientador de las lecturas y de las demandas del público. Sus intereses interactúan con los intereses políticos y económicos de variados sectores de poder. Esta vinculación debería ser investigada para dar cuenta de la complejidad de relaciones entre el campo intelectual y el campo de poder.

En este marco debemos destacar que la obra literaria entra en un horizonte de expectativa en el que la comprensión crítica de las normas estéticas no excluye a la política. Aspecto éste que, como elemento fundante de la literatura argentina, está en la base de la política institucional y de una política de la escritura que se enfrenta con el fragmentarismo cultural, la competencia de los medios, la necesaria modificación del canon, el desplazamiento del privilegio del campo literario por el del campo de ficción. El efecto consecuente trasciende lo estético para abarcar una dimensión epistemológica.

\section{Una propuesta de lectura}


La amplitud y riqueza de los enfoques críticos acerca del testimonio, así como los problemas teóricos que generan, revela, por cierto, la complejidad del tema que nos ocupa.

Mi lectura se propone observar cómo se produce y circula el relato testimonial en la Argentina de fin de siglo y cuál es su función en ese campo de ficción. Con tal motivo, realizaré un análisis de las obras en su textualidad para detectar particularmente las estrategias narrativas que configuran su mundo ficcional. En tal sentido, a mi juicio es importante prestar atención por un lado al sujeto narrativo, y por otro a las relaciones intertextuales, siempre considerando las características propias de todo relato testimonial, que he enunciado en apartados precedentes.

Sin embargo, no estaría ofreciendo una lectura productiva si no estableciera un diálogo entre las obras que conforman el corpus, para construir de este modo una red textual y establecer comparaciones. Plantearé un eje organizador: la representación de la década del setenta que produce cada texto, entendiendo la representación como construcción creativa, en virtud de la teoría del relato que he explicitado anteriormente.

Al mismo tiempo, considero que no sería posible dar cuenta de la función del relato testimonial en el campo cultural si no me detuviera en la interdiscursividad con otros relatos. Así es como mi lectura recuperará los aportes de las obras La Voluntad (volúmenes I, II y III), de Eduardo Anguita y Martín Caparrós, y Nunca más. Ambos textos son, según creo, pertinentes como soportes discursivos referenciales. El corpus se completa con otras obras que resultan ejemplificadoras de diferentes grados de ficcionalidad y de las que aquí presento, en principio, una breve sinopsis:

- José, de Matilde Herrera (1987)

El relato presenta una versión íntima, privada, de la subversión, de la violencia y del "ser humano" desaparecido. La voz de la madre-mujer restituye el cuerpo, profundiza la "presencia" en la "ausencia".

Se problematizan los géneros biográfico, autobiográfico y testimonial. Se distancia de la biografía política tradicional en la Argentina para instalarse en la 
biografía pública que vuelve a la infancia como "historia de vida" del otro. La imagen es otra estrategia del recuerdo que materializa la memoria y refuerza la escritura. La voz narradora es representativa de un sector de resistencia, las Madres de Plaza de Mayo.

* $\quad$ Recuerdo de la muerte, de Miguel Bonasso (1983 -1ª ed.- y 1994)

Como paradigma de la novela testimonial expone al lector una configuración del testimonio y una función abierta al análisis. La producción de sentidos está centrada en el análisis crítico del discurso que marca la representación de la década del setenta.

La lectura de los marcos paratextuales la sitúan en el fin de siglo y explicitan su función pragmática. Puesta en diálogo con La memoria en donde ardía (1992), el otro libro de Bonasso, se amplía el horizonte de sentido en virtud de las voces narrativas, su focalización, el contenido del relato testimonial que conforma la trama de esta novela y la problematización del género. Crea una estética del dolor y la tortura con un análisis político que concentra el valor ético del texto.

* $\quad$ El fin de la historia, de Liliana Heker (1996)

La novela instala una revisión del género testimonial y autobiográfico desde la ficción. La escritura femenina, desde otra perspectiva y voz, crea un marco interesante de comparación con la obra de Matilde Herrera.

El lector es protagonista en la construcción de un texto que se lee a partir de su clausura. Construye una estética o una erótica del dolor y la tortura para producir un efecto ético-político. Su estrategia narrativa central se funda en la configuración de un referido sobre las ausencias y presencias que el lector debe descubrir poniendo la obra en diálogo con los otros textos.

Los textos mencionados, que serán objeto de la investigación, reúnen una condición específica: pueden considerarse como un tipo ficcional que se propone representar la realidad mediante sentidos acordados en un pacto ficcional que se asocia a algún tipo de validación. Por un lado evocan convenciones novelísticas, pero además requieren que el lector acepte que ciertos elementos textuales tienen referente en el mundo real. 
* Notas

${ }^{1}$ En su obra Testimonio hispanoamericano: historia, teoría, poética, New York, Lang, 1991.

${ }^{2}$ Achugar, Hugo. Prólogo. En otras palabras, otras historias. Universidad de la República, Uruguay, 1992.

${ }^{3}$ Beverly, John. Introducción (Revista de Crítica Literaria Latinoamericana. $\mathrm{N}^{\circ}$ 36, pág. 13)

${ }^{4}$ Ibidem, pág. 13

${ }^{5}$ Ibidem, pág. 15

${ }^{6}$ En su obra Telling the Truth. Cornell University Press, Londres, 1986.

7 Especialmente en su ensayo "Épica y novela" (En Teoría y estética de la novela, Madrid, Taurus, 1989).

${ }^{8}$ El concepto de "comprensión" es utilizado aquí en el sentido bajtiniano del término: "No se pueden separar comprensión y valoración: son simultáneas y constituyen un acto total. El que comprende se acerca a la obra con una visión del mundo propia y ya formulada, con su punto de vista, desde sus posiciones. Estas posiciones en cierta medida determinan la valoración de la obra, pero simultáneamente ellas mismas no permanecen invariables: se someten a la acción de la obra que siempre aporte algo nuevo...En el acto de la comprensión se lleva a cabo una lucha, cuyo resultado es un cambio y un enriquecimiento mutuo". Esta definición se opone a la explicación-interpretación, que según Bajtin "...se reduce a este descubrimiento de lo repetible...de lo conocido...desaparece la individualidad del creador...se asimila al que comprende... En lo ajeno reconoce únicamente lo suyo". (En Estética de la creación verbal, México, Siglo XXI Editores, 1985, págs. 363-364).

${ }^{9}$ En su ensayo "Document as Novel" (En Literatura y Testimonio, Minnessotta, Jara Vidal, 1984).

10 Según el alcance del término para Walter Mignolo. Teorías del Texto e interpretación de textos, México, Universidad Autónoma de México, 1984.

11 José Amícola señala que el punto culminante de la teoría de Sklovski no se halla en el concepto de ostranenie sino en el rol que le cabe al procedimiento literario en el arte, y cita a Sklovski diciendo: "El arte es el modo de vivenciar el hacer de las cosas; pero en el arte lo hecho no 
es importante". (En De la forma a la información: Bajtin y Lotman en el debate con el formalismo ruso, Rosario, Beatriz Viterbo Editora, 1997, pág. 62).

${ }^{12}$ Amícola, José, op. cit.

${ }^{13}$ Angenot, Marc. Interdiscursividades. De hegemonías y disidencias, Córdoba, Editorial Universidad Nacional de Córdoba, 1998, págs. 95-96.

14 Bessière, Jean. "Literatura y representación" (En Angenot, Marc y otros, Teoría Literaria, México, Siglo XXI Editores, 1993, págs. 356-375).

${ }^{15}$ Propuesta de Frank Kermode en su libro El sentido de un final, Barcelona, Gedisa, 1983.

${ }^{16}$ Martínez Bonati, Félix. La ficción narrativa (Su lógica y ontología), Murcia, Universidad de Murcia, 1992.

17 Mignolo, Walter. "Semantización de la ficción literaria". (En Dispositio, vol. V$\mathrm{VI}, \mathrm{N}^{\circ}$ 15-16, págs. 85-127. Department of Romance Languages, University of Michigan, ¿???)

${ }^{18}$ En "El estatuto lógico de la ficción" (s.d.e.)

${ }^{19}$ Recordemos que la teoría de actos de habla contempla el lenguaje como una actividad en la que el hablante ejecuta otras acciones con su decir: promesa, orden, etc., actos ilocutivos que tienen consecuencias performativas.

20 Tales reglas son: 1. Esencial: quien hace una aserción se compromete acerca de la verdad; 2. Preparatoria: el hablante debe estar en grado de poder probar la verdad que expresa; 3. De cortesía: la proposición no debe ser obvia; 4 . De sinceridad: el hablante se compromete a creer en la verdad de la proposición.

21 Me refiero a teóricos como Félix Martínez Bonati, quien plantea que en literatura no es el autor quien habla sino el discurso mismo, por lo tanto la fuente de lenguaje es ficticia. (Op. cit., págs. 101-103). Por su parte, Gérard Genette, aunque comparte con Searle la perspectiva pragmática de la ficción, considera sin embargo que los actos ilocutivos de los personajes de ficción son auténticos, lo que significa dejar de lado la ficción en primera persona, cuyos actos ilocutivos son del narrador-personaje, mientras el autor no cumple ningún acto como tal; Genette opina que el autor produce un acto de lenguaje indirecto. (En Ficción y dicción, Barcelona, Lumen, 1993). Tal vez la crítica más radical es la que plantea Jacques Derrida en su ensayo Firma, acontecimiento y contexto, al considerar que la escritura no es un medio de representación de la comunicación oral sino que es desplazamiento y ausencia. Derrida entiende a la escritura como 
estructura reiterativa, separada de la responsabilidad de su creador. Esto supone una ruptura del concepto de comunicación y de representatividad del sentido, así como del de intencionalidad, que resulta básico para Searle. Finalmente, podemos mencionar a Walter Mignolo, quien ha hablado de la semantización de la ficción literaria a nivel del enunciado y de la enunciación, centrándose en la problemática de un doble discurso que remite a dos responsabilidades: la del narrador y la del autor. Como consecuencia, demuestra la impropiedad de trasvasar la categoría de locutor de acto de habla a la literatura.

${ }^{22}$ En su obra La lógica de la literatura, Madrid, Visor, 1995.

${ }^{23}$ En su obra Tiempo y narración. Configuración del tiempo en el relato de ficción, Madrid, Siglo XXI, 1995.

${ }^{24}$ Este concepto es desarrollado por Thomas Pavel en su libro Mundos de ficción, Monte Avila, Caracas, 1991, págs. 71-82.

${ }^{25}$ Eco, Umberto. Lector in fabula, Barcelona, Lumen, 1981.

${ }^{26}$ Mignolo, Walter. Op. cit., pág. 110.

${ }^{27}$ Ricoeur, Paul. Op. cit., pág. 533.

${ }^{28}$ CONADEP (Comisión Nacional sobre la Desaparición de Personas).

${ }^{29}$ Robert, Marthe. Orígenes de la novela y novela de los orígenes, Madrid, Taurus, 1973, pág. 19

${ }^{30}$ Foley, Barbara. Op. cit.

${ }^{31}$ Bajtin, Mijail. Op. cit., pág. 451.

${ }^{32}$ Angenot, Marc. Op. cit., pág. 81.

${ }^{33}$ Sobre "nueva novela histórica" me parece interesante la introducción de Mignon Domínguez al libro Historia, ficción y metaficción en la novela latinoamericana contemporánea, Buenos Aires, Corregidor, 1996. Presenta allí un esbozo de diversos enfoques críticos sobre la nueva novela histórica y establece relaciones entre los diferentes desarrollos teóricos.

${ }^{34}$ Jitrik, Noé. Historia e imaginación literaria, Buenos Aires, Biblos, 1995.

35 Jitrik desarrolla ampliamente esta idea cuando hace referencia a la irrupción del romanticismo en Europa y señala que surgen entonces preguntas sobre la identidad, de las que se ocupa fundamentalmente la novela histórica. Dice que el imaginario se reorganizó en torno a un ser eminentemente social y los textos intentan responder a la pregunta 
central sobre el ser que lo informa y lo caracteriza. En América Latina, en cambio, si bien las preguntas también se formulan en relación con la identidad, se especifican en el aspecto nacional, se interroga sobre la identidad de una comunidad.

Paul Ricoeur, en su excelente obra Tiempo y narración, ya citada, ha desarrollado esta teoría del relato centrada en los conceptos de trama y temporalidad, cuya relevancia opera solamente por el contacto entre mundo del texto y mundo del lector

37 White, Hayden. Metahistory, Baltimore, The Johns Hopkins University Press, 1973.

38 Publicado en Trópicos do discurso. Ensaios sobre a critica da cultura, Universidad de Sâo Paulo, 1994.

${ }^{39}$ Ibidem, pág. 115. (La traducción es mía).

${ }^{40}$ Ricoeur, Paul. Op. cit., pág. 916.

${ }^{41}$ Ibidem, pág. 1001.

${ }^{42}$ Recordemos que Barbara Foley identifica dos manifestaciones de la novela documental: la novela metahistórica y la autobiografía ficcional.

43 Hutcheon, Linda. "Historiographic Metafiction" (En: Currie, Mark, ed. Metafiction, New York, Longman, 1995, págs. 71-91).

44 Waugh, Patricia. "What is Metafiction and why are they Saying such awful things about it?" (Ibidem, págs. 39-54).

45 Lejeune, Philippe. "El pacto autobiográfico" (En Antropos, suplemento No 29, diciembre 1991, págs. 47-60).

${ }^{46}$ Ibidem, pág. 51.

47 El crítico Nicolás Rosa, en su estudio El arte del olvido (Buenos Aires, Puntosur Literaria, 1990), realiza un análisis de la teoría de Lejeune y sus alcances.

${ }^{48}$ Rosa, Nicolás. Op. cit., pág.56.

49 Olney, James. Metaphors of self. The meaning of autobiography, Princeton University Press, 1973, págs. 30-31.

${ }^{50}$ Bruss, Elizabeth. “Actos literarios” (En Antropos, op. cit., pág. 62)

${ }^{51}$ Op. cit., pág. 37. 
52 Bajtin, Mijail. Estética de la creación verbal, México, Siglo XXI, 1982, pág. 139.

53 Ibidem, pág. 138.

${ }^{54}$ Hamburger, Käte. Op. cit., pág. 54.

${ }^{55}$ En la recopilación titulada En otras palabras, otras historias, ya citada.

${ }^{56}$ Para una aproximación a la obra de Rodolfo Walsh consultar los trabajos de Ana María Amar Sánchez, Elzbieta Sklodowska y la revista Nuevo Texto Crítico, citadas en la bibliografía de esta tesis.

57 Coincido con la afirmación de Kathleen Newman, quien señala esta continuidad entre los escritores en su obra La violencia del discurso. El estado autoritario y la novela política argentina. Buenos Aires, Ed. Catálogos, 1991.

58 Ibidem, pág. 156.

${ }^{59}$ En su obra El sentido de un final, Barcelona, Gedisa, 1983.

60 Sarlo, Beatriz. "¿Arcaicos o marginales? Situación de los intelectuales en el fin de siglo". Revista Punto de Vista, n 47, 1993.

61 Ludmer, Josefina. Las culturas de fin de siglo en América Latina, Rosario, Beatriz Viterbo Editora, 1994.

${ }^{62}$ Concepto de Pierre Nora. Les lieux de memoire, Paris, Gallimard, 1987.

${ }^{63}$ Ocupan este espacio la revista Pájaro de fuego y los best - sellers.

${ }^{64}$ Representado en la crítica por la revista Punto de Vista.

${ }^{65}$ En el concepto de Paul Ricoeur, en op. cit.

${ }^{66}$ Sarlo, Beatriz. Op. cit., pág. 2. 
Capítulo II

\section{Lecturas del pasado en dos obras de Miguel Bonasso}


Las novelas de Miguel Bonasso que analizaré en este apartado, Recuerdo de la muerte y La memoria en donde ardía, se ubican en el horizonte textual de la Argentina finisecular y desarrollan particularmente la relación entre la literatura y la historia, pero siempre mediatizada por el periodismo. Así es como la escritura recupera la memoria narrativizando los hechos del pasado para resignificarlos en función de sus efectos sobre el presente. En tanto, la lectura construye los sentidos a partir de la memoria colectiva que se materializa en el relato de ficción, pero cuyos referentes son los discursos histórico y periodístico.

Mi análisis se detendrá en la inmanencia textual y en el reconocimiento de las relaciones intertextuales, que son propias de la novela como género fundado en la citación de otros. Luego las pondré en diálogo con otras obras que conforman el campo cultural de la Argentina de fin de siglo para restituir las articulaciones de sentido que conforman la red discursiva.

La hipótesis central que orienta mi lectura es que estos textos producen una representación de la sociedad de la década del setenta en sus aspectos culturales, políticos y éticos, constituyendo una respuesta estética que tiene en el presente un efecto ético y epistemológico. Esta última dimensión muestra cómo, en las relaciones entre las disciplinas, la literatura propone una forma de conocimiento de la realidad para un público diferente y más amplio.

\section{I - Recuerdo de la muerte}

\section{Lo testimonial}

Recuerdo de la muerte es una obra que puede ser considerada como un paradigma de la novela testimonial cuyo motivo es la violencia y el poder en la década del setenta. Ahora bien, ¿cómo se configura lo testimonial?. Mencionaré aspectos que algunos teóricos han considerado relevantes para la definición del género y que se registran en esta novela: el relato enmarcado, la referencia a lo real, la interdiscursividad. 
Así podemos ver cómo el relato discurre en un marco temporal señalado entre "enero de 1979" y "abril de 1980-septiembre de 1983", y un marco discursivo: "Epílogo a manera de prólogo" y "Crónica final".

Es posible también verificar cómo lo testimonial se construye con referencia a lo real. Se trata de una novela centrada en un personaje, en un momento de la vida "temporada" de Jaime Dri, en el decir irónico del autor. Sólo que este personaje tiene existencia en el mundo real y es el testigo que "...un día se puso a investigar con nosotros. Un día desenmascaró a los asesinos...un día lo puse como personaje en un libro".

Es un personaje individual, pero su paso por la Escuela de Mecánica de la Armada (ESMA) y la Quinta de Funes da cuenta de la historia argentina de los setenta desde la perspectiva de los montoneros. Muestra un abanico de relaciones entre dos bandos que actúan como antagónicos, pero tienen semejanzas en su origen: son nietos de inmigrantes y esto desencadena sus diferencias: unos son militares porque buscan ascenso social y otros son montoneros para recuperar sus orígenes de lucha y resistencia. Unos y otros enfrentan las diferentes aristas del poder. El espacio físico de la represión es un submundo que organiza e influye sobre el macrocosmos que es el país.

En ese macrocosmos los montoneros tienen su organización. Los traidores colaboran con los militares y se disputan el protagonismo en la toma de decisiones (Nacho, el Tío). La resistencia de los que no se han quebrado se exhibe con diferentes estrategias: la de aquellos que exponen el cuerpo hasta la muerte como el Sordo, la de quienes oponen la inteligencia a la fuerza y logran huir como Tucho o el Pelado. Y la más persistente es el archivo, la palabra escrita. El diario es un instrumento de lucha, de acción contra el tiempo y el olvido, es el espacio material del conocimiento, es un lugar de memoria contra la represión.

Los militares tienen a su vez un personaje central, el "Tigre" Acosta, como nexo entre ambos mundos. Muchos otros no tienen identidad, al punto de convertirse, con el discurrir de la narración, en "un Gustavo". El signo que los caracteriza es la crueldad, la inclinación hacia las mujeres, el abuso y la obsecuencia con el poder y su falta de formación intelectual. En este punto 
parece como si el texto retomara la antigua oposición civilización-barbarie, propia de la literatura romántica argentina.

Si bien éste es el núcleo narrativo, existen también referencias al pasado de Jaime Dri; se recurre entonces a la biografía como recurso para profundizar en el personaje y darle una dimensión social e histórica. Así, los capítulos titulados "Lejanías" refieren su infancia, su juventud, su militancia, siempre vinculada a hitos políticos de nuestro país, como la década del treinta, 1955, la década del sesenta. La biografía está en función de la historia de la Argentina cuyo común denominador es la violencia del Estado que se ejerce sobre los civiles como un estigma que se hereda de padres a hijos.

La condición esencial de la novela testimonial es su función política. En la novela de Bonasso el lector se encuentra frente a un testigo que muestra cómo se despliega y quién ejerce el poder en la década del setenta, pero sobre todo cómo se proyecta sobre la democracia de los ochenta.

Finalmente, la tercer característica que mencioné, la interdiscursividad, se hace evidente por cuanto el relato, enmarcado desde lo discursivo, es sin embargo un texto sin clausura. Plantea una continuidad entre la escritura y la lectura. El autor-lector-investigador cita sus referentes: Nunca más; "Carta abierta de un escritor a la Junta Militar", de Rodolfo Walsh.

Éste es el horizonte en el que el lector puede "comprender" el texto en el sentido bajtiano, pero también los nombres propios tienen una actualidad que lo orientan a bucear en su propio contexto de recepción en otros textos, como La Voluntad, de Eduardo Anguita y Martín Caparrós.

Hasta aquí he enunciado ciertos aspectos que configuran lo testimonial. Sin embargo, Recuerdo de la muerte es también leída como una novela y así lo especifica su título. En tanto tal, se incorpora a la institución literaria y establece con el lector un pacto ficcional. Es la ficción la que constituye el mundo posible en el que tienen voz los muertos y los desaparecidos, en el que el mismo autor es protagonista de una historia narrada en tercera persona.

Del mismo modo, las estrategias narrativas propias de la novelística le permiten al autor recuperar hechos, espacios y personas del pasado que han tenido existencia real, algunos de los cuales aún hoy intervienen en la esfera pública del país. El relato presenta para el lector un "camino de descubrimiento 
del pasado personal e íntimo del personaje. Pero también...la trayectoria de Dri es un eje articulador de las evocaciones del pasado político y público."

Mi lectura del texto ha recuperado tres núcleos organizadores de la "evocación" a la que Miguel Bonasso se refiere:

* La actividad de los montoneros antes del golpe.

* Los objetivos de la Junta Militar y en especial el proyecto de Massera.

* El destino de los montoneros frente al aparato de represión que montara el gobierno militar.

Estos momentos señalan al lector una nueva opción, que es establecer con el texto un pacto de veridicción. La impresión de realidad proviene fundamentalmente, a mi criterio, de dos factores. Aquellos que atienden a la competencia del lector, quien puede construir su saber recordando, pues las experiencias de los personajes son colectivas, o recurriendo a otros textos recientemente editados y que pertenecen a la investigación periodística, y por otra parte, la existencia de textos que en la inmanencia de la obra son citados como documentos, provocando la legitimación de los hechos narrados: testimonios, cartas, artículos periodísticos con explícita indicación de sus fuentes. Es así como la actividad de lectura es un vaivén que pone en contacto a las distintas áreas: literatura, historia, periodismo.

Mi análisis se detendrá en dos aspectos del relato como una forma de ingreso a la obra que permite dar cuenta de múltiples sentidos: la configuración de una estética de la violencia y la voz del narrador.

En cuanto al primer aspecto, entiendo que es relevante la descripción del microcosmos de los "desaparecidos", donde la tortura es un motivo siempre presente, aún in absentia. Sus procedimientos, agentes y efectos subyacen en la organización y las relaciones de ese submundo.

La narración se detiene en aspectos morbosos y en el dolor físico mediante la cita de testimonios que dan validez a los hechos, pero también metaforiza el aparato represivo y sus efectos. Por ejemplo, al describir la capucha (pieza de tela utilizada para cubrir la cabeza del prisionero, acentuando su sometimiento), dice:

"La capucha y las vendas constituyen una precaución de los torturadores: los protegen de la mirada de la víctima. Pero cumplen 
otra función: encierran a la víctima en sí misma. El mundo entero ha quedado en tinieblas... No están allí los compañeros, la familia, los amigos. La capucha ha suprimido toda historia y todo porvenir. Es un negro presente de soledad y desamparo... No sólo impide mirar afuera, obliga mirar hacia adentro... La capucha reduce el mundo a una sola decisión, a un único temor. Es sabia. Más sabia y menos benevolente que la muerte". (pág. 44).

Este sujeto sin mundo propio es definido por el propio texto como un "desaparecido":

"Recordó entonces la palabra: desaparecido. Alguien que flota entre la vida y la muerte [...] Bueno, de todos modos cientos pudieron morir peleando. Él no. No había tenido esa suerte. Le tocaba ese final lleno de asechanzas. Ser machacado hasta dejar de ser..." (págs. 51-52)

Sin duda, el lector se encuentra ante una estética diferente; no es lo bello sino el dolor su signo. En este caso, el dolor conlleva un riesgo: ser o no ser, la identidad del sujeto, que depende de su resistencia a la traición. La tortura es un medio para mostrar otra cuestión más profunda: el poder de unos sobre otros. La necesidad de poseer el cuerpo y la voz para que la víctima deje de ser "otro". Como afirma Elaine Scarry:

“...torture is a form of savagery and stupidity... that has a structure. This structure may be in part premeditated... and is in either case based on the nature of pain the nature of power, the interaction between the two... the body, the locus of pain, and de voice, the locus of power". 1

La estética de la violencia, con sus componentes reales, sus agentes y sus medios, y también sus metáforas, se transforma en una erótica. La relación del Tigre y Pelusa narrada en el capítulo VI es un ejemplo. La relación sexual reproduce el enfrentamiento de dos fuerzas: torturador-víctima, militarmontonero, hombre-mujer. Representan un hecho concreto, la tortura, su alcance político y su relación con el género de la humanidad. En esa confrontación se revierte el resultado de la tortura. En el acto sexual el hombre, militar, torturador, resulta vencido. 
- "Siempre inmóvil, crucificada por las comparaciones, Pelusa sintió la derrota del macho". (pág. 352).

Puede interpretarse aquí un ideologema del autor: la fuerza de la violencia captura el cuerpo pero no al sujeto, que conserva una alternativa de resistencia. El silencio para el hombre (Dri), la falta de entrega en la mujer. La complejidad de las relaciones en ese microcosmos está dada justamente por esa capacidad de resistencia. El narrador llama al lector a participar y en su voz se lee el enjuiciamiento, pero también un reconocimiento de su posición desde afuera:

"A priori usted o yo que tuvimos la suerte de no trasponer los portones de la Escuela, podriamos jurar que la influencia 'dominante' era la de los carceleros. Pero la realidad no es tan simple". (pág. 345)

El efecto que produce esta estética es de solidaridad para con los "montoneros" y de censura para los "quebrados". Las razones de esta posición se centran en cuestiones que es posible enunciar de la siguiente manera:

1) El dolor no tiene voz, sus límites son el propio cuerpo; es privado.

2) Nadie que no sufra el dolor, que no sea el "yo" puede comprender la situación de la violencia.

3) El interrogatorio es la motivación que justifica al torturador y la respuesta es por el contrario la razón de censura para la víctima.

Estos fundamentos están en el texto, y es sobre todo en la voz del narrador y del personaje, en las descripciones de los quebrados donde se lee el ideologema del autor. Es allí donde se le señala al lector una posición que transforma la aproximación estética en ética.

"Después recordaría: 'yo creía antes de caer que lo que te sostiene e impide que seas un traidor son tus puntales ideológicos y políticos.

Son importantes. Pero mucho más importante fue el temor a dejar de ser yo mismo...".. (pág. 52)

El segundo punto de análisis del que me ocuparé, tal como anticipara, es la voz del narrador. Creo importante destacar al respecto algunas cuestiones.

En primera instancia, las voces que presentan el mundo narrado muestran desde la subjetividad los pensamientos, los sentimientos, las acciones. La 
focalización es un recurso a su servicio y consiste en citar el monólogo interno de un personaje o narrarlo; en intervenciones del narrador en complicidad con el lector; o simplemente relatar en tercera persona desde el punto de vista de uno de los personajes como narrador omnisciente.

Estos recursos de composición incorporan voces que dialogan y coexisten en la novela a través de diferentes tipos discursivos: la carta, la crónica, el informe, la entrevista periodística.

Las voces representan, además, distintas conciencias como visión y comprensión del mundo del texto para que el lector lo refigure. Se reconocen la de los militares y las de los montoneros, estos últimos en un espectro que diluye las fronteras entre ambos bandos.

Luego, es evidente que la condición de narrador omnisciente permite conocer el sentir de los personajes, sus pensamientos, e inclusive muchas veces saber más que los mismos personajes. Cuando dice, por ejemplo:

"Ignoran y seguirán ignorando hasta leer estas líneas que Nacho ha estado a un tris de volver a pasarse de bando". (pág. 164).

Es interesante observar cómo en el capítulo "Crónica final" se establece una diferencia entre los tiempos del enunciado y de la enunciación. El narrador cuenta hechos posteriores en la historia del país, como la guerra de Malvinas y explicita su tesis política e ideológica.

Pero la mayor concentración de su posición política y del efecto sobre el lector se encuentra, indudablemente, cuando el narrador realiza una evaluación de los hechos con diversos procedimientos; la ironía es uno de ellos. En la descripción de Massera dice:

“¿Y ese día que entró al sótano y pidió dar máquina él también?

Qué delicadeza para con sus hombres, qué tacto...". (pág. 76).

Otra estrategia textual significativa que expresa la ideología del narrador se encuentra en el fluir de conciencia del personaje:

"¿Qué es esto? La demostración de que somos hombres y no superhombres... La libertad me parece a veces que es como un resquicio, una pequeña rendija y se parece a la oportunidad...". (pág. 340). 
Finalmente, el tercer aspecto a señalar es que el narrador se presenta a sí mismo como autor y testigo del juicio a Dri y dice:

"Dri estuvo acompañado en el estrado por Multerand, Jospin,

Fernando Vaca Narvaja... y el autor de este libro". (pág. 439).

Por otra parte, así ingresa al texto como personaje. Para un lector que conoce datos básicos de la biografía de Miguel Bonasso esto es un aspecto verificable que corresponde a la realidad más que a una estrategia discursiva. Es así como el narrador actúa como una bisagra entre lo testimonial y lo ficcional.

La presencia del autor testimoniado y ficcionalizado es una forma de legitimar el conocimiento del autor real, su identificación con el personaje y su ideología partidaria, su condición de testigo que garantiza la "verdad".

Mi lectura ha observado lo testimonial y lo literario en estrategias textuales que fundan un pacto de ficcionalidad con el lector en diferente grado. Ese pacto incluye una fuerte argumentación con efecto político.

\section{Discurso y representación}

En este marco general interrogaré al texto sobre la representación de la sociedad de la década del setenta. Buscar una respuesta implica optar por una perspectiva de abordaje, el análisis crítico del discurso en este caso.

Mi elección se fundamenta en las potencialidades que ofrece el espacio textual para establecer una relación particular entre discurso y sociedad. La conformación discursiva permite dar cuenta de las relaciones de poder y de la manera en que los integrantes de los distintos grupos sociales las reproducen o le oponen resistencia en la representación narrativa. En este sentido, el estudio realizado se orienta a dar cuenta de las relaciones múltiples existentes entre los distintos sectores políticos e identificar los ejes semánticos que los aproximan o los alejan. El análisis crítico del discurso nos ha permitido además subrayar las ideologías que subyacen en las estrategias de dominación o resistencia legitimadas en el nivel discursivo.

En la novela Recuerdo de la muerte he identificado dos grupos políticos: montoneros y militares. Sin embargo, se presentan otros grupos, tanto en uno 
como en otro bando, con posiciones fronterizas en lo que respecta a su ideología acerca de las relaciones de poder y de conceptos estructurales como pueblo, patria, guerra, paz, vida.

En el grupo que identifico como montoneros puedo señalar diferencias discursivas entre aquellos que se mantienen fieles a la doctrina, como el Pelado, Tucho, o el Nariz, y aquellos que son llamados "quebrados", tales los casos de Nacha y Nacho, por citar ejemplos. Un tercer grupo estaría representado por el Chacho, que refunda otra organización con nuevos registros semánticos.

En cuanto al grupo militares, los discursos significativos desde el punto de vista de su estructura y estrategias discursivas, corresponden a personajes como el Tigre y Massera. No obstante, en las zonas de indeterminación ideológica aparecen algunos casos como el Chispa.

A continuación respetaré estos dos grupos, militares y montoneros, para realizar el análisis político de sus respectivos discursos.

\section{- Los militares}

Para caracterizar al grupo "militares" he seleccionado los siguientes textos:

- Monólogo del Tigre en "Primera temporada en el infierno", capítulo VI, págs. 75 a 87 .

- Discurso de Massera en el mismo cap. VI, págs. 79 a 83.

- Arenga del Tigre. "Tercera temporada en el infierno", cap. IV, págs. 329 y 330.

- Monólogo del Tigre

El texto seleccionado se encuentra enmarcado por la emisión "La mañana había empezado mal para el Tigre pero ahora se abría esplendorosa".

Luego, el narrador en tercera persona introduce el enunciado que fundamenta la acción y el sentir del personaje: "El Almirante lo había llamado", que se intensifica semánticamente por medio de la reiteración: "Lo había llamado a él solo"; "El Almirante lo había llamado a él". 
Se focaliza el vocablo "solo" y la forma pronominal "él". Este recurso destaca la distinción del hablante (el Tigre) y lo polariza con la importancia del sujeto del enunciado (el Almirante). Las reflexiones del sujeto de la enunciación van delineando en la escena discursiva la representación del Almirante. Su valoración de Massera se modela a través de los siguientes tópicos:

* La juventud, signo de progreso y actualización.

* La elocuencia con que se manifestaba hacia los personajes o hacia la gente en general.

* La apariencia de galán, por su expresión clara en el éxito con las mujeres.

* Las condiciones de mando le otorgaban identidad militar.

La juventud del Almirante, el primer tópico que he enunciado, se destaca por una estrategia comparativa con Chamorro e indirectamente con (el contralmirante Isaac) Rojas, por oposición. Se va construyendo así un paralelismo de oposiciones que pone de relieve al Almirante, a quien una y otra vez se hace referencia como una mezcla bien dosificada de marcialidad y jovialidad.

Mediante el uso de un lenguaje coloquial que le posibilita la selección de vocablos y giros como "pintón", "minas", "se derretían", el sujeto de la enunciación coloca en la escena discursiva a un Massera reivindicado por su apariencia, rescatado como estampa porteña, con ese algo de "Gardel".

Sus condiciones de mando, su imagen de bravura, de "bancar" junto con todos la represión en pos del "arma" que "se juega entera", quedan enaltecidas en el recuerdo del Tigre, frente a la actitud más medida y grotesca de Chamorro y hasta por "la insoportable colonia". La confrontación se convierte así en una estrategia discursiva que muestra el accionar sobornador del Almirante y el debate interior del Tigre para convencerse a sí mismo de que es apoyado y distinguido.

Este juego discursivo del monólogo abre espacios a la participación del lector, que acompaña por un lado la lucha interior del personaje que se debate entre "exaltación" y "depresión", y que por otra parte asiste a los simulacros y movimientos orquestados en función de la represión, presentados con la misma 
naturalidad de lo cotidiano. La pregunta se convierte en un acicate del recuerdo y va apagando las dudas y reforzando la exaltación.

Una cita directa de la voz de Massera, cuya intervención focaliza la explicación final, fundamenta todos los tópicos. "El arma se juega entera” (pág. 76).

Así es como podemos observar que en el texto de estructura narrativa subyace una estructura argumentativa cuyo esquema básico es de hipótesisconclusión, términos relacionados sobre la base de su derivalidad sintáctica, implicación semántica y conclusión pragmática.

La legitimidad de la argumentación está dada en el marco de un código que concentra su carga semántica en el término "arma". Esta secuencia argumentativa funciona a su vez como explicación de la subsiguiente, que se inicia con el sintagma "Porque él sí que estaba actualizado. Él entendía adónde quería ir a parar el Almirante”. (pág. 76)

Un nuevo discurso argumentativo se desencadena a partir de una relación comparativa Acosta-Massera que se expresa en una construcción condicional interrogativa:

“Si Massera había llegado, ¿por qué no podía llegar él?” (pág.

81).

Las estrategias argumentativas se refuerzan con construcciones comparativas que destacan los rasgos comunes de ambos personajes e incorporan a la narración los datos biográficos. Esta información ingresa en dos facetas de la vida de Massera: la política y la privada.

“... no había sido también un oscuro oficial de inteligencia?” (pág.

81)

“... y Massera estaba donde estaba porque lo puso el gobierno peronista” (pág. 82)

“... él también era luterano como Massera” (pág. 82)

Aquí el encadenamiento argumentativo que articula la secuencia narrativa aproxima la polarización inicial "Massera y él", ya que ambos se presentan con las mismas ansias de poder político, poder que se muestra sostenido por el peso de los hilos tejidos por el "arma" a la que pertenecen y que los une en cuanto a los códigos de pensamiento y acción. 
La narración coloquial permite al sujeto de la enunciación hacer comentarios o emitir opiniones que van mostrando las representaciones generales acerca de determinados sujetos sociales como en "ciertas ingenuidades tan propias de los marinos...", o bien en el rasgo "ladino y taimado" que aparece asociado a "la sangre india".

Otras veces, las reflexiones nos muestran el alcance todopoderoso del Almirante, cuyo despacho era imaginado por el Tigre como "ámbito casi divino". Por otra parte, sus evocaciones ponen en escena las características que le sirvieron a Massera para convertirse en el "líder de su camada", en el verdadero "vivo" y también en beneficiario de algunos permisos vedados a otros, como "el trago" y el ser "burrero" y "mujeriego".

\section{- Discurso de Massera}

Bajo una forma aparente de diálogo por las evidencias lingüísticas que pueden identificarse, se impone, sin embargo, un monólogo. La forma discursiva expresa la relación de poder que vincula a ambos personajes (Massera-Acosta) y que puede hacerse extensiva a las relaciones jerárquicas de la fuerza (el "arma").

La unidad de análisis seleccionada es el párrafo semántico y los tópicos organizadores son la patria y la guerra.

La patria es considerado el valor supremo del servicio. En cuanto a la distribución de la información este párrafo semántico presenta un tema: "patria", y tres categorías remáticas que responden al mismo campo semántico: "sacrificio", "entrega", "servicio".

La evaluación del sujeto de la enunciación recae sobre el nexo del valor "demanda", que posibilita la personificación de la patria en quien se traslada la responsabilidad de las acciones demandadas y categorizadas como "sacrificio", "entrega" y "servicio". La reiteración del adjetivo "total" otorga el valor a la acción "dar" y refuerza el significado de las categorías remáticas involucradas en un campo semántico de sumisión.

"Con estos tiempos que corren, la Patria nos demanda un sacrificio total. Una entrega total... Eso es, total, al servicio. ¿Me explico?". (pág. 83) 
Otro tópico es la guerra, que es impuesta, pero se considera ya ganada y se justifica por la búsqueda de paz. Se registra en expresiones como:

- "La guerra que estamos librando no la hemos elegido, nos la han impuesto. Lo que es peor, se la han impuesto a una juventud que podría ser valiosa, que podría ser recuperable para la Patria, cuando deje de oír el canto de sirena de los nihilistas, de los que aman la muerte ¿Me explico?”

- "Esta guerra la vamos a ganar. No tengo dudas. Porque sé (como lo dije alguna vez), que no vamos a combatir hasta la muerte. Sé que vamos a combatir hasta la victoria, esté más acá o más allá de la muerte [...] (pág. 84)

El tema "guerra" se desarrolla con dos categorías remáticas: una señala el origen de la guerra, la otra indica su resultado. En cuanto a la primera se destacan los constituyentes inmediatos del nexo de valor que establecen un paralelismo: Nos la han impuesto/se la han impuesto.

En el primer caso se incluye el sujeto de la enunciación y su interlocutor, a través del pronombre "nos". En el segundo, el sujeto de la enunciación se aparta, con una mirada más objetiva, y focaliza otra víctima regida por su concepto de imposición: la juventud. Esto le da sentido al tema principal "guerra": recuperar a la juventud para servir a la patria.

La segunda categoría remática que hemos enunciado como resultado de la guerra se construye con una modalidad declarativa, con fuerte presencia del sujeto de la enunciación en la reiteración del verbo saber: "sé"; su compromiso transforma el acto del habla en una promesa.

Si a esto se agrega la construcción parentética y la afirmación "le decía", por las que se hace presente la inclusión del interlocutor y se afirma la importancia del verbo decir, la elocución adquiere las características de una arenga política, pues aproxima la relación enunciador-receptor y del decirhacer.

La promesa de victoria se sustenta mediante dos enunciados con valor argumentativo: por el poder de la violencia y por el apoyo del pueblo que quiere la paz. Esta última emisión es un nuevo tópico que tiene un carácter explicativo 
del tema "guerra": el pueblo que quiere paz es un factor de apoyo y de poder para el autollamado "Proceso".

El nexo de valor "quiere" vincula el concepto pueblo-paz y reivindica para ello otras acciones del mismo campo semántico: "comer", "ir al cine", "educar a sus hijos". La enumeración los hace sintácticamente equivalentes, de modo que el significado paz = vida se plantea como el eje de la filosofía del "Proceso".

El lector puede inferir que esta proposición se opone a guerra = muerte, asociada a los montoneros en la expresión anterior: “...cuando deje de oír el canto de los que aman la muerte”. (pág. 84)

La cadena semántica descripta explicita pues que la "filosofía del Proceso" es que la guerra que se está ganando tiene un justificativo ético, la patria, y una razón pragmática, conseguir la paz para el pueblo que la reclama. Sin embargo, el tópico de ganar la guerra cede su paso al de "conseguir la paz", puesto que es eso lo que se asoma como incógnita en el sujeto de su enunciación.

La expresión "Me preocupa cómo vamos a ganar la guerra" (pág.84) encierra un interrogante cuya respuesta traslada el interés del ámbito militar al de la política económica. Se desarrolla una intencionalidad del sujeto de la enunciación: alcanzar el poder militar y el poder político, síntesis del gobierno del país.

El sintagma "Ésa es la filosofía del Proceso" (pág. 85) se presenta como una conclusión. El término "ésa" es el rema cuyo desarrollo se encuentra en los tópicos anteriormente enunciados y el tema es la "filosofía del Proceso", que ubicado al final de la oración clausura toda otra posibilidad de rematización. Ratifica con esta distribución de la información un discurso verticalista y monológico que no admite la voz "otro".

La modalidad interrogativa del enunciado registra la presencia del interlocutor y se ofrece la estrategia interactiva de su búsqueda de acercamiento a través de las preguntas: “¿Me explico?” o “¿No es cierto?”.

La totalidad del tramo del discurso de Massera es identificado por el interlocutor como un prólogo: "Adivinaba que estaba en el prólogo y no lograba descubrir el hilo de Ariadna que lo condujera al final del laberinto”. (pág. 85). Se 
inicia de este modo una segunda parte del discurso. El enunciado con modalidad imperativa se formula en primera persona del plural y con el adjetivo "nuestra", lo que incorpora al interlocutor en el propósito:

"Tenemos que crear algo nuevo".

"Hay que ganar arrepentidos para nuestra causa". (pág. 85)

Este procedimiento elimina las jerarquías que se habían establecido anteriormente y reorienta el eje del discurso, que desplaza lo militar y enfatiza su función política. Una evidencia lingüística clara al respecto es la utilización de expresiones que constituyen lugares comunes: "destino de grandeza", o la reiteración del léxico propio de este discurso, como por ejemplo la palabra "mística".

"El problema es que hace falta una nueva mística... tenemos que crear algo nuevo. Así la gente producirá contenta y el país alcanzará su destino de grandeza. Sin esa mística estamos perdidos. Esta gente que combatimos tuvo una mística...". (pág. 85).

El narrador refuerza estas características discursivas desde su relato del punto de vista del personaje: "Por un lado había aumentado su fidelidad al Jefe, por otro lo abrumaban ciertas ambigüedades que nacían del Massera político". (pág. 87). Aquí se explicita la intencionalidad del sujeto: convencer a su interlocutor de que "tenemos que ganar arrepentidos..."

De este modo puedo sintetizar lo expresando afirmando que la estructura discursiva fundante es argumentativa y se desarrolla mediante un encadenamiento de información que registra dos afirmaciones:

Una: "Ésa es la filosofía del Proceso" (el argumento de sostén) y la otra: "Tenemos que ganar arrepentidos".

Me detendré ahora en el análisis del segundo discurso seleccionado: la arenga del Tigre.

\section{- Arenga del Tigre}

La voz del personaje el Tigre se introduce en el texto, con estilo directo y tono imperativo, mediante un guión que indica presencia de un diálogo que en 
realidad se transforma en monólogo como réplica de la relación jerárquica militares-"chupados".

El texto se organiza en cuatro párrafos semánticos que pueden identificarse como:

- Exaltación del triunfo militar sobre los montoneros y exhortación a comprometerse con la causa militar.

- Consigna para colaborar en la búsqueda del Nariz (propósito de la arenga).

- Promesa de recompensa.

- Advertencia.

La modalidad de la enunciación imperativa y con un matiz de obligatoriedad es reforzada por el uso de frases verbales como "tendrían que...", "tienen que...". El sujeto de la enunciación se presenta en el texto con la fuerza explícita del "yo voy a tener en cuenta...", "me voy a acordar..." y en un tono amenazante que va creciendo desde la reiteración del adverbio "ningún" en el primer párrafo, la expresión exclamativa y onomatopéyica "iguay...!" (que recupera para la escritura la fuerza de la oralidad) y la atracción apelativa de "mírenme bien...", hasta la culminación en la expresión que concentra la intencionalidad última del enunciado: "No habrá un próximo Nariz".

Este registro revela la finalidad del discurso: evitar que se expanda el ejemplo de fuga y desplazar a un segundo plano la solicitud de colaboración. La modalidad del enunciado armoniza con la de la enunciación y toma el ritmo de una aserción contundente.

“Ningún delincuente... ningún traidor... ningún nihilista va a poder detener nuestra marcha inexorable hacia el triunfo. Porque el tren no se detiene, aplasta... y iguay del que ose ponérsele en medio! [...] Vamos a fundar una República para cien años [...] y otra cosa más [...] y ustedes van a colaborar en la cacería [...] yo voy a tener en cuenta la iniciativa [...] y ahora una última cuestión... No habrá un próximo Nariz." (págs. 329 - 330).

El poder dominante de la discursividad se refuerza mediante el uso de palabras que funcionan al servicio del plan arrasador: "inexorable", "aplasta", "cacería". La estructura argumentativa subyace nuevamente en el discurso al 
servicio de la táctica de persuasión y de infundir miedo. La última frase, "no habrá un próximo Nariz", cierra toda posibilidad de desarrollo remático y obliga a buscar en los tópicos antes señalados los argumentos que sustentan semánticamente esta hipótesis; la discursividad reproduce, de este modo, la relación de poder dominador-dominado.

El primer párrafo semántico ${ }^{2}$ exalta el triunfo y el poder militar sobre los montoneros. Esa superioridad se presenta en primera instancia con una estrategia discursiva: el ejemplo y la comparación con una escena de la vida cotidiana que establece las equivalencias recíprocas animalito/Nariz = tren/militares. Luego, mediante la reiteración de la expresión "vamos ganando".

A veces el tono amenazante es matizado con alguna promesa de esperanza futura como la emisión de enlace "vamos a fundar una República para cien años", que conduce semánticamente al tópico del segundo párrafo: la exhortación a comprometerse con la causa militar. Esta emisión funciona como un argumento para captar la voluntad de los "chupados" y se refuerza reafirmando la relación de poder planteada en el primer párrafo, cuando el sujeto de la enunciación dice: "Todos los que están acá deben saber que no tienen comprada su libertad. Ni siquiera tienen comprada la vida...” (pág. 330). Establece en este enunciado una homologación militares-Dios, como estrategia persuasiva que se basa en el temor a la prisión y a la muerte por oposición a la libertad y a la vida.

En el segundo párrafo semántico, identificado como "consigna para colaborar en la búsqueda del Nariz", se explicita el propósito pragmático del acto de habla: movilizar al interlocutor para actuar. Siempre ratifica la relación dominador-dominado, mediante el tono de intimidación volcado en expresiones reiteradas como "más vale", que intensifica la amenaza y el efecto de miedo: " $y$ ustedes van a colaborar en la cacería. Así que, más vale que se preparen. Más vale que estén lúcidos..." (pág. 330).

El discurso pone en evidencia también la ira del sujeto de la enunciación en una elocución más desordenada que produce una transposición del "yo" en la posición del "otro". Toma la voz del otro y la cita en estilo directo para terminar en la emisión que contiene el mayor valor semántico: "tienen que poner iniciativa". El sujeto de la enunciación hace una transposición de voces y 
se coloca a modo de ejemplo como una manera de reforzar el poder persuasivo de su discurso. Con un matiz de obligatoriedad instala al otro en la necesidad de actuar con iniciativa.

"Ese diez por ciento que significa: yo me acuerdo de tal cosa o me acuerdo de... o no sé. No me importa... lo que quiero decir es que tienen que poner iniciativa”. (pág. 330).

El tercer párrafo semántico, denominado "promesa de recompensa", responde a una estructura sintáctica de proposición causal. El primer término de la proposición está organizado en torno de la reiteración de la frase verbal "voy a tener en cuenta...", que constituye el acto de habla en la acción pragmática de prometer.

"Yo voy a tener en cuenta la iniciativa. Voy a tener en cuenta la buena voluntad y me voy a acordar luego cuando llegue el momento de hacer algo por él." (pág. 330).

La promesa es de recompensa y su credibilidad se desarrolla en la instauración que hace al sujeto de su condición de marino. Aquí el enunciado rescata la representación de un imaginario frecuente en la sociedad argentina: la condición de "hombre de honor".

"Porque yo... no soy un ingrato. No soy un mercenario de la mentira. Soy un oficial de la Marina. Un hombre de honor..." (pág. 330).

Semánticamente vincula los valores de gratitud, verdad y honor con la condición de ser "oficial de la Marina". La construcción unimembre "Un hombre de honor" funciona como una ampliación del sintagma anterior. En esta construcción el sujeto de la enunciación sintetiza su valoración del "arma".

El párrafo final condensa la intencionalidad última de la arenga: la advertencia. Así, dice “Mírenme bien!”, incorporando al interlocutor al texto para enunciar la sentencia que clausura el discurso: "No habrá un próximo Nariz".

Este discurso, que hemos caracterizado como monológico y argumentativo, recibe sin embargo una respuesta anticipatoria del proyecto narrativo mediante un paralelismo discursivo. Escuchamos la otra voz, la voz de la réplica: "Estás equivocado Tigre: claro que hay un próximo Nariz. Ese próximo soy yo". Establece una identidad Nariz-Pelado en la acción "escapar" y 
disuelve la efectividad del discurso como estrategia de persuasión, provocando así una fractura entre la fuerza ilocutiva y un efecto perlocutivo no unánime.

En síntesis, los tres textos seleccionados constituyen una cadena semántica de estructura explicativa sucesiva: el objetivo de los militares es alcanzar el poder político sostenido por el poder del arma que los une en código de pensamiento y acción. Este código se sintetiza en la emisión "Ésa es la filosofía del Proceso".

Se instalan así cuatro ejes temáticos: la patria, el pueblo, la guerra y la paz. Y la acción es ganar "arrepentidos". Con este fin, la discursividad se convierte en un mecanismo de poder que se sintetiza en cuatro actos de habla significativos: persuadir, apelar, amenazar, prometer.

\section{- Los montoneros}

Para caracterizar al grupo "montoneros" se seleccionaron los textos que permiten dar cuenta de la ideología y relaciones de poder que se establecen entre dos sectores: los fieles a la causa, como el Pelado y Tucho, y los "quebrados", localizados en el microcosmos que es la Quinta de Funes en la que identificamos al Tío y Nacho como representativos. Por otra parte, se establece una vinculación militares-montoneros con algunas notas diferenciales con respecto a la establecida en la ESMA y que hemos descripto a través de la arenga del Tigre. A partir de este deslinde, realizaré el análisis de los siguientes textos:

\section{- El Pelado}

- El archivo: último parágrafo del Cap. V y primero del Cap. VI de la "Segunda temporada" (págs. 340 a 347)

- Fluir de su pensamiento (págs. 254 y 313)

- Testimonios de la Negra (pág. 114)

- $\underline{\text { Tucho }}$

- Diálogo con Galtieri (pág. 199) 
- Carta de Tucho (pág. 227)

- Juicio y sentencia (pág. 242)

- Los "quebrados" de la Quinta de Funes

- El Tío (págs. 154 y 155)

- Nacho (págs. 172 a 178)

Dentro del corpus ahora elegido, me interesa detenerme especialmente en algunos tipos discursivos citados por la narración como estrategias de verosimilización:

- Artículos periodísticos (págs. 226 - 234)

- Crónica (pág. 207)

- Confesión (pág. 396)

- Testimonios (pág. 135)

Estos textos adquieren la siguiente función: completan la información y establecen los roles, destinos, acciones y relaciones militares-montoneros.

El desarrollo del análisis anunciado es el siguiente:

\section{- El Pelado}

* El archivo

Seleccioné el último parágrafo del capítulo $\mathrm{V}$ y el primero del capítulo $\mathrm{VI}$, que desde el punto de vista semántico responden al mismo tópico. La estructura del texto presenta dos secuencias que tienen un punto de encuentro en la palabra "archivo". La primera secuencia temática constituye la explicación de la segunda.

Me detendré en el análisis de la primera secuencia, en la que señalaré los siguientes tópicos:

- La oposición hombres - superhombres.

- La definición de libertad como libre albedrío y oportunidad.

- Las dos concepciones de "organización" y su relación con el concepto de "vida". 
La enunciación tiene una modalidad interrogativa que constituye la estrategia discursiva principal para el proceso del texto. Le permite además intercalar su propio pensamiento y hacer partícipe al lector. Este desarrollo discursivo se plantea así como una problematización de los tópicos que desarrolla la relación hombre-superhombre y la definición de libertad.

La pregunta "¿Qué es esto?" actúa como una emisión desencadenante de un enunciado aclaratorio del pronombre "esto": "La demostración de que somos hombres y no superhombres". Este sintagma, cuyo tema es "la demostración", presenta una construcción remática fundada sobre la oposición hombresuperhombre que involucra a su vez la presuposición de que los montoneros fueran considerados así o se consideraran a sí mismos superiores.

La ampliación del campo semántico de la palabra "hombre" se logra mediante construcciones semánticas yuxtapuestas, cuyo efecto es a su vez la yuxtaposición de roles:

"Aquí mismo, en la Pecera, están reunidas todas las posibilidades. Viniendo desde siempre a cumplir su papel: el que se pasa de bando como Alfredo; el Judas que un día puede ahorcarse como Diego; el tipo angélico como Mateo, que sigue siendo inocente dentro del infierno; el maquiavelo como Chacho que juega todas las cartas al poder de la inteligencia". (pág. 340).

Esta construcción que desarrolla "todas las posibilidades" presenta una sintaxis apoyada sobre construcciones comparativas y subordinadas sustantivas que producen sucesivas ampliaciones de la información.

La segunda pregunta, "Uno es libre... ¿o qué?", introduce otro tópico: la libertad. En esta instancia la modalidad interrogativa produce sucesivas ampliaciones del campo semántico de dicho tópico (solidaridad, libre albedrío), hasta llegar a la sentencia declarativa que concentra la definición en la que se hace presente el sujeto de la enunciación.

"La libertad, me parece a veces, es como un resquicio, una pequeñisima rendija y se parece a la oportunidad". (pág. 340)

La cadena semántica relaciona libertad, yo, oportunidad. La operatividad discursiva de esta cadena se enmarca en la situación contextual que subraya la importancia ocasional de la consideración pragmática. Se produce así un 
desarrollo semántico para provocar un llamado de atención en el oyente ubicándolo en las circunstancias. El rema es en este caso "oportunidad", cuya ampliación se produce mediante una estrategia retórica, el uso de una metáfora cuyo centro es el término "pecera", que transforma su significado literal por el uso de minúscula y establece las siguientes equivalencias: pecera = Pecera, peces $=$ "chupados", pescador = "militares".

El desarrollo de enunciados aclaratorios de los conceptos "hombre" y "libertad" se completan con el de "vida" cuando al reiterar la pregunta “¿Qué es esto, Chacho?", la discursividad devela el misterio focalizado: "que estemos vivos...".

Chacho es presentado por el narrador en su aspecto de pulcritud y buena apariencia física pero calificado por las apreciaciones del Pelado como otro "artista del disimulo". Sin embargo, su perfil se construye por medio de su propio relato a través del cual se instaura, por un lado, como testigo de las actividades desarrolladas en la ESMA y a la vez como protagonista de la constitución de la "nueva organización que ha decidido salvarse y salvar a todos los que pueda".

En este sentido, el juego de la primera persona singular del espectador ("yo vi deshacerse...") da paso a la primera persona del plural activo ("constituíamos una nueva organización...") hasta llegar a la apelación directa a su interlocutor ("mirá Pelado ...") en un juego de advertencia y autoritarismo en el que vuelven a plantearse las relaciones de poder. Esta trayectoria del sujeto de la comunicación va enlazando diversos tópicos que se erigen en los fundamentos que encaminaron la posibilidad de realización de la nueva organización. De este modo, el relato pone en evidencia el saber superior de los montoneros (en general intelectuales) sobre los militares. Todo ello se desarrolla con una estructura argumentativa que desemboca conclusivamente en la advertencia.

Tanto para el Pelado como para Chacho la vida es sinónimo de lo útil, pero tienen diferente destinatario: una nueva organización salvadora o el servicio a los intereses militares. Afirma: "Y la única forma de romper ese algo es fugarse." (pág. 344). Sendos personajes plantean diferentes mecanismos de resistencia en la relación dominador-dominado: la colaboración y la fuga, la 
prisión y la libertad, la nueva organización cuya prioridad es la vida de cada uno y la organización montonera, cuya preocupación es la causa que los ampara a todos.

La segunda secuencia del texto que he seleccionado es inaugurada por el término "archivo", cuyos desarrollos remáticos se localizan en las proposiciones ampliatorias:

- “... un punto de reunión espontáneo de los habitantes de ultratumba...” (pág. 344)

- “... se había ido convirtiendo en la tertulia de la ESMA." (pág. 344)

- “...sustituto del café o del club... tierra de nadie donde se entremezclan promiscuamente las ilusiones y las creencias, los rencores y los afectos de los que habían combatido hasta la muerte." (pág. 345)

El "archivo" expresa la complejidad de la realidad de la ESMA, en la que se explicita lo que los dos bandos tienen en común:

- "habían combatido hasta la muerte" (pág. 346)

- "Vos y yo éramos, somos combatientes" (pág. 346)

Ambas expresiones exaltan un valor: el coraje.

La voz del Chispa enuncia una crítica a los militares desde adentro. Su emisión es formulada con oraciones exclamativas y semánticamente se acerca al pensamiento guerrillero.

"Y ustedes van a tener piedad porque son mejores, porque no están podridos como nosotros. Mi viejo, veo a mi viejo y a sus amigos. Todos en los negocios... todos en la joda..." (pág. 347)

El "archivo" es un espacio físico y también un espacio discursivo que permite al narrador presentar a los dos bandos que conviven en la ESMA. La estrategia discursiva empleada es el inventario, construido en torno de la presentación como una ficha cuyo esquema organizativo contiene: tema, que es el nombre propio, y rema, que es la descripción física, su rol en la ESMA, sus antecedentes en el caso de los "chupados"; mientras que para los militares se destaca la fuerza a la que pertenece y su obediencia a un jefe, Massera, y el Tigre.

En conclusión, el análisis crítico del texto seleccionado nos ha permitido efectuar un registro de las evidencias lingüísticas que dan cuenta de las 
ideologías que convivieron en el espacio de la ESMA, en donde el ejercicio del poder también se ha revelado discursivamente. Este análisis pone de relieve la complejidad de la realidad y traspone las relaciones entre los opuestos dominador-dominado estableciendo un abanico de posibilidades en los roles y las posiciones ideológicas.

El discurso de la resistencia apela a tópicos en los que subyace una ideología:

$\diamond$ La libertad es la única garantía de la vida individual. La vida es útil en tanto se ponga al servicio de la organización y sus ideales.

$\checkmark$ Para un montonero son condiciones de valor el coraje y la resistencia hasta la muerte y se oponen a ellas la colaboración y la traición. Esto es sentido como la única alternativa real de oposición al poder del dominador que está centrado en la violencia y la fuerza.

$\checkmark$ Pero la discursividad evidencia que existe un poder alternativo al de la fuerza, el poder del saber, el del intelectual. En este marco es posible establecer relaciones de cooperación entre montonerosmilitares con el objetivo de crear una nueva organización para salvar vidas. La vida tiene un alcance individual, pues ha perdido su sentido trascendente, aquel que le ofrecía la organización Montoneros, considerada ya destruida. Si bien la respuesta es diferente, sin embargo ambas posiciones coinciden en que el poder militar dominador reside en la violencia y la fuerza.

$\diamond$ Otro aspecto de resistencia discursiva al dominador puede inferirse de la sobrevaloración hacia el dominado, de su coraje, de sus condiciones humanitarias, que surge de la desvalorización de la propia fuerza. Este cuestionamiento está basado en un código ético que produce una fractura entre el ser y el parecer.

La posición ideológica del Pelado que he presentado tiene una explicación desarrollada en dos textos cuya conformación discursiva analizaré: el fluir de su pensamiento y el testimonio de la Negra.

- Fluir del pensamiento (capítulo VII - "Lejanía") 
La emisión se presenta en un modo coloquial y recupera expresiones propias de la oralidad para establecer una comunicación encubierta con un interlocutor cuya voz se introduce a través de construcciones parentéticas resaltando así la presencia discursiva de la primera persona del sujeto de la enunciación. La estructura del discurso presenta un segundo esquema; dos preguntas organizan los temas del texto:

- “ ¿Uno es libre o qué?

- “Cómo explicarte esta historia que yo mismo no tengo muy clara?”

Sus respuestas constituyen el desarrollo remático de los temas libertad e historia. La primera pregunta que se formula el sujeto de la enunciación, con una modalidad deliberativa, presenta dos alternativas:

- "hay un momento en el cual tú eliges pero luego las circunstancias te llevan hacia lo que no habías previsto".

- "las circunstancias te condicionan para que tomes tal o cual decisión". Luego enuncia una conclusión con una modalidad declarativa:

- "Ahora bien, yo me metí, yo fui, yo soy libre".

El verbo "soy" o "fui" se constituye en un nexo de valor cuyo significado establece una correspondencia entre yo $=$ libre.

La segunda pregunta introduce el tema "historia". Las categorías remáticas que llevan la carga semántica está en la relación con "mi historia", "la otra historia", "esa historia". En esta última expresión el adjetivo "esa" abarca a los otros dos en una relación de correspondencia explicitada por el sujeto de la enunciación, también en una construcción que expresa una conclusión.

- "Ahora bien, volviendo a mi historia que dicho sea de paso no tiene importancia, si no es para referirnos a la otra historia".

Las preguntas que desarrollan esa relación entre lo privado y lo colectivo son introductorias para un nuevo discurso biográfico en tercera persona.

- El Testimonio de la Negra

Este texto tiene, por un lado, una función explicativa, pues le da marco y sentido a la ideología del Pelado, y por otra parte es ampliatorio, conlleva su historia privada. Es testimonial en tanto se trata de un relato en primera persona del singular que alterna con el plural, en su condición de protagonista y 
juez de los hechos. La estructura del relato presenta dos momentos cuyos ejes temáticos son la persecución, la huida y la búsqueda de refugio para la familia, y el secuestro de los hijos.

La incorporación del estilo directo elimina toda voz narrativa y establece un vínculo con el lector en los que se destaca el sentimiento, la solidaridad y el temor.

- "Yo me traigo la gallega a vivir con nosotros" (pág. 115)

Se vincula la vida privada con la historia colectiva que le da sentido, mediante una emisión de modalidad declarativa:

- "La guerra popular prolongada. Es prolongada".

La sintaxis unimembre junto a la oración bimembre reafirma el concepto "prolongada"; sin embargo se retoman dos aspectos que se inscriben en un modo dubitativo según la posición del sujeto de la enunciación, pero que por su forma interrogativa proponen la participación del lector: "¿Es guerra?”; “¿Es popular?” (pág.115). Esta construcción del discurso con alternancia de voces refleja la inestabilidad y la incertidumbre que se desarrolla en la acción organizadora antes mencionada.

La segunda parte destaca los aspectos afectivos en la relación padrehijos, que se refuerza mediante la incorporación de un texto epistolar. Ambos momentos tienen como común denominador la denuncia; la primera parte en forma impersonal, la segunda con identificaciones precisas de los protagonistas de ambos bandos; Tucho y Galtieri, por ejemplo.

En conclusión, la vinculación de los textos seleccionados permite leer una tesis: el compromiso político implicaba subordinación de lo individual a lo colectivo y el marco que le daba sentido a esta conducta estaba localizado en la estrecha relación entre historia privada e historia pública. Esta última signada por la violencia. La fidelidad a la causa que se muestra a través del personaje el Pelado representa asumir una posición: aún los afectos más esenciales al hombre están expuestos; el riesgo trasciende la propia vida. De allí que existe una relación explicativa entre ambos textos.

- $\underline{\text { Tucho }}$ 
* La carta de Tucho a Galtieri

La carta adquiere un sentido acabado si se la pone en relación con el diálogo Galtieri-Tucho. Los tópicos que conforman el contenido de este último texto caracterizan la ideología militar:

- Sus preocupaciones políticas se centran en lo económico: el hambre y las multinacionales.

- Los objetivos de la lucha militar son la libertad, la familia y la paz, fundados siempre en valores cristianos.

- Las estrategias militares tienen una base o antecedente en el proceder de los nazis.

Estos mismos tópicos son retomados en la carta, y así son leídos desde otro tipo textual y se completa la situación comunicativa de diálogo entre ambos. La carta constituye una respuesta a las afirmaciones vertidas en el enunciado del diálogo Galtieri-Tucho.

El género epistolar ofrece una condición: lleva lo público y colectivo al plano de lo personal y privado. Este procedimiento humaniza los conceptos y transforma el espacio textual en un ámbito de libertad de expresión, en el que el sujeto de la enunciación puede ejercer las posibilidades de resistencia que le brinda la palabra. Este espacio textual elimina las relaciones jerárquicas dominador-dominado y facilita un encuentro de sujeto-sujeto en las figuras textuales de locutor-alocutario.

Realizaré el análisis de la carta teniendo en cuenta las siguientes unidades: contenido y estructura, y estrategias discursivas.

El objetivo del análisis del discurso es verificar la confrontación ideológica entre montoneros y militares, propósito que ha orientado hasta aquí todo este trabajo, pero en este caso, por las características del tipo discursivo y su relación con otros textos de la novela, se descubre una nueva esfera de significados.

Así, he identificado cinco momentos constitutivos de la estructura discursiva, que fueron localizados en función de los tiempos de la enunciación.

* El primer momento corresponde a los dos primeros párrafos en los que en un tiempo verbal presente el sujeto de la enunciación señala una eliminación de jerarquías respecto del destinatario y una toma de posición "frente a frente", 
así explicitada por el texto. Se abre la posibilidad de desarrollo textual ante la emisión "por segunda vez" que remite al pasado y hace que el texto subsiguiente sea explicativo de esta expresión.

* El segundo momento se centra en el pasado, por lo que el texto presenta una estructura narrativa, con características propias del testimonio. El relato en primera persona está a cargo de un narrador que es protagonista y juez de la historia narrada.

Lo testimonial se afirma también en la evaluación de los hechos. Por ejemplo en "sólo habíamos conquistado el gobierno, pero no teníamos el poder", emisión en la que se focaliza el valor semántico del adverbio "sólo". También en afirmaciones como "una política condenada por la historia", que es anticipatoria por su construcción centrada en el participio "condenada", que lo ubica en el presente.

El tópico que organiza su contenido es la identificación montonerospueblo, que se constituye en el eje semántico del texto que va creciendo con el desarrollo de las cadenas semánticas del discurso.

* El tercer momento inscribe el texto en el tiempo presente del sujeto de la enunciación. Adquiere la estructura del discurso político, cuyo avance se produce por el encadenamiento de términos cuyo valor semántico se va ampliando en los sucesivos párrafos.

“... un combate entre la astucia y la fuerza [...] Venció la astucia... yo lo he vencido y mi movimiento ha transformado una derrota militar táctica... en una victoria política... (pág. 228)

Tampoco la suya es una derrota personal... es la derrota de una política condenada por la historia.(pág. 228)

Una política de hambre, represión...” (pág. 228).

Resulta claro que se desarrolla la oposición militares-montoneros a partir de conceptos que los caracterizan: astucia-fuerza, derrota militar-victoria política. El paralelismo planteado en el primer momento en la expresión "frente a frente" se transforma en un agón usted-yo, Galtieri-Tucho. Sin embargo, la proposición adversativa reinstala el "yo" en la relación montoneros-pueblo.

"el principal protagonista ha sido el pueblo que resiste y yo un mero instrumento de implementación" (pág. 228) 
Lo individual se extiende a lo colectivo para destacar la representatividad de cada uno: Galtieri-Estado Mayor del Ejército; Tucho-pueblo. Se plantea la disolución del sujeto individual en un sujeto colectivo que representa distintos estratos sociales: el militar representa a militares, un estrato cerrado; el montonero representa al pueblo, amplio y numeroso. Como consecuencia, las relaciones montoneros $=$ pueblo, montoneros $\neq$ militares, se resuelve en una tercera: militares vs. pueblo.

El texto adquiere una modalidad explicativa de la denominada "victoria política". La estrategia se centra en la descripción de la representación que cada bando tiene del desembarco aliado en Normandía y la hipotética resistencia nazi en Berlín. El lenguaje exhibe dos maneras de interpretar un hecho histórico para enunciar la valoración del sujeto de la enunciación: "Ustedes no son los aliados... son la cosa más parecida a los nazis...".

* El cuarto momento ubica los hechos en el futuro a través de proposiciones condicionales con una modalidad exhortativa. El tópico es la pacificación nacional, que sustenta su pedido en el alcance semántico del verbo "comprender" y en la representación que el sujeto de la enunciación tiene de los valores cristianos, entendidos como respeto por la vida.

La diferencia sustancial entre montoneros y militares se focaliza en su vinculación con el pueblo expresada en emisiones como:

- "han estado luchando contra el pueblo"

- "por lo que nuestro pueblo lucha desde hace muchos años"

Los objetivos de la lucha representan principios éticos diferentes; fundados en lo privado uno y en lo colectivo otro: la familia, la libertad, la paz, por un lado; la independencia económica, la justicia social, la soberanía política por el otro.

Con modalidad declarativa el sujeto de la enunciación sentencia "El pueblo vencerá" y clausura una cadena semántica para abrir otra que se organiza como estructura argumentativa. Las estrategias discursivas se centran en la oposición semántica de términos que caracterizan a cada sector:

Montoneros

- justicia de nuestra causa
Militares

- injusticia de la de ustedes 
- grandes mayorías populares

- nuestro pueblo sabe

- número, justicia, lucha
- pequeñas minorías oligárquicas

- el Ejército no sabe por qué lucha

- organización, fuerza.

La emisión "Nosotros venceremos" clausura el texto argumentativo y reafirma la identidad nosotros/pueblo $=$ montoneros, que se lee en relación con la exhortación final: "Tiende la mano al pueblo que nosotros se la sabremos recibir".

En síntesis, la puesta en diálogo de los textos mencionados ha establecido una diferencia montoneros-militares desde suposiciones éticas e ideológicas en torno a un eje que es el pueblo. La caracterización contiene un profundo enjuiciamiento a los valores que orientaron el accionar de los militares, al punto que no los localiza en el presente sino que los inscribe en su repercusión en la historia. La palabra como acto de habla elimina las jerarquías y refuerza la condición de igualdad de fuerzas y roles en ambos bandos. El poder de cada uno se sostiene en el código ético y los propósitos de vida que orientan las diferentes conductas.

* El juicio a Tucho

Los textos que analizaré y que se nuclean en torno al juicio a Tucho se centran en el espacio discursivo de los montoneros. La estructura textual está constituída de la siguiente manera:

En primer lugar por una introducción en la voz de Firmenich, que presenta registros propios de la oralidad, como reiteraciones e invocaciones al auditorio

"Se trata de que... el Partido sintetice con su teoría y su práctica, sobre todo con su práctica. Sintetice, decía, las inevitables contradicciones entre la cuestión individual... yo diría la contradicción entre dos opuestos: la esfera de los intereses individuales... y los intereses colectivos que el Partido exprese" (pág. 244).

Su contenido plantea los siguientes tópicos:

- Los intereses colectivos del partido y del pueblo deben prevalecer sobre los intereses individuales. 
- La sanción debe ser ejemplarizante para el conjunto y contemplar la recuperación.

- El valor de la sanción ha variado según las circunstancias.

Este último tópico se presenta con una estrategia discursiva: el ejemplo, y tiene una funcionalidad que trasciende los límites de este texto pues se constituye en soporte que fundamenta la sentencia a Tucho e incluso a Jaime Dri.

En segundo término se verifica en la estructura textual la acusación en la voz de Perdía y Firmenich, en la que encontramos tres instancias:

- Un discurso jurídico cita en forma directa el código violado por el delito.

- Un discurso coloquial, con modalidad imperativa, que trasunta ya su sentencia: la culpabilidad.

"¿Te das cuenta que vos no podés violar esa doctrina o no te das cuenta?" (pág. 246).

- La síntesis de Firmenich, que con una modalidad declarativa es explicativa de las expresiones de Perdía. Su relación está dada por el subordinante "por qué", el que establece una continuidad entre un discurso y otro. Representa un grado de complejización del discurso que se logra mediante un nexo de valor en modo indicativo: "podrías haber...", "podía llegar a...", "hubiera puesto". Centra la evaluación en lo que pudo hacer o pasar y no en lo que realmente pasó. Desconoce el sujeto de la enunciación un hecho real y lo sitúa en el plano hipotético: el peligro de la vida y la compañera de Tucho.

En tercer lugar aparece la defensa, que se expone en un discurso argumentativo organizado ("Al juzgar los delitos objetivamente cometidos...", pág. 246), y que también se presenta cargado de emotividad. Su registro está en evidencias lingüísticas con reiteraciones ("yo sé, yo sé...") o uso de vocablos vulgares ("es más jodido"). Se focaliza en este caso una emisión que contiene toda la carga semántica y argumentativa de la defensa ("yo les salvé la vida", pág. 247) y se constituye en un tema cuya ubicación al final del texto deja abierta la posibilidad de desarrollo remático en otro texto: la sentencia.

Finalmente, la sentencia constituye una respuesta semánticamente inversa a la acusación, pues se desencadena a partir de la emisión que clausura el juicio y que es eje de la defensa: "yo les salvé la vida". 
En los "Vistos y considerados" predomina la negación en lo lexical y sintáctico de la primera afirmación que hace referencia al código y a los cargos. Con una modalidad imperativa se focaliza el concepto "atenuantes" a partir del cual se produce la complejización del discurso marcado por negaciones: "no corresponde", "tampoco corresponde", "de ninguna manera podría implicar..."

La contradicción más profunda entre la acusación, el código y la sentencia se encuentra en el último párrafo, con la afirmación "Tucho debe ser castigado, con la máxima severidad que permite nuestro código..." (pág.248). Como consecuencia, se genera una ambigüedad entre el "deber ser" y el "ser": ¿cuál es la razón que marca la diferencia?. La subjetividad del emisor de la sentencia, que no puede ser imparcial pues es parte y beneficiario de los hechos. La acusación está fundada en los intereses colectivos; la sentencia, sin embargo, en los intereses individuales del tribunal revolucionario. Firmenich, Perdía, no pueden ejecutar el código, pues el "atenuante" es "yo les salvé la vida". No obstante, las causas que absuelven a Tucho son otras que el lector sí registra y el tribunal no lo hace, más bien las niega. Son causas individuales, pero de quien corrió los riesgos: el sacrificio de su familia, las circunstancias que resistió.

El discurso señala así una "deshumanización" en el proceder del Partido, pero que es arbitraria, no incluye a la conducción, ya que lo que el lenguaje puso en evidencia se materializa en otra instancia de la novela, en otro juicio, el que el autor-narrador hace a los jefes montoneros desde otro tiempo histórico. Los hechos documentados y narrados ratifican lo que el discurso había anticipado: los jefes montoneros encontraron siempre el mismo "atenuante" por sus acciones: "salvar su vida".

La complejidad de la "Operación México", sus dificultades, se evidencian en los artículos periodísticos, los testimonios y una crónica de los hechos. La novela cita estos tipos discursivos que, puestos en diálogo con el juicio a Tucho o aún a Dri, constituyen las pruebas de sus "atenuantes" legítimos. Son discursos que contribuyen a crear la "realidad novelada que es 'Recuerdo de la Muerte", en términos de Bonasso. 
En franca oposición al planteo ideológico-político que representa Tucho, se encuentran los llamados "quebrados" en el texto, discurso que analizaré a continuación.

\section{- Los "quebrados" de la Quinta de Funes}

El diálogo con el Tío y con Nacho tienen una función en el contexto extralingüístico: exaltan el heroísmo de Dri y de Tucho. La situación de los traidores se fundamenta con la afirmación "El Ejército nos ganó" (pág. 154) y las estrategias argumentativas se apoyan en dos tipos de construcciones:

- Los sintagmas encadenados que complejizan el discurso desarrollando el concepto antecedente y que están en función de recalificar positivamente al Ejército.

"...dentro del Ejército hay tipos como la gente. Nacionalistas.

Gente que no está vendida."

- Las emisiones declarativas: "acá no se puede pensar en hacer un Ejército propio y cagarlos. Ese fue nuestro error...", cuya intencionalidad es la evaluación del pasado, desde el interior de la organización Montoneros.

La evaluación, el juicio de la traición, se evidencia en el pensamiento del Pelado a través de una enumeración de preguntas que contienen en sí una respuesta. Su cuestionamiento a los traidores se sustenta sobre la responsabilidad que el individuo tiene sobre lo colectivo. Por eso, el diálogo con Nacho profundiza un aspecto motivador de la traición: los intereses individuales, la propia vida y la necesidad de reproducir el mundo privado en la Quinta. Se acentúa el sentimiento mezquino, especialmente en la reiteración del diminutivo "igualito".

“... ¿a que no sabés lo que pasó?. Me habían traído a Laika, la perrita y habian trasladado nuestro dormitorio. Con todas nuestras cosas. Estaba igualito... Pero igualito a como lo dejé... Igualito" (pág. 172).

La Quinta de Funes es un micromundo en el que se reproducen relaciones jerárquicas de poder entre los "quebrados" como una nueva organización y también entre quebrados y militares. En ese espacio se 
individualizan dos figuras: Jaime Dri y Tucho, fieles a la causa que motorizó a la organización Montoneros, que van configurando una trayectoria heroica.

\section{Novela y política: una lectura}

A modo de síntesis me interesaría recuperar la pregunta motivadora de la lectura que he realizado: ¿Cómo representa esta obra la década del setenta?.

Quiero detenerme en el concepto de "representar", que sin duda instala un problema teórico de amplio alcance (Ver Capítulo I). Me limitaré aquí a plantear, aunque sólo sea a título de hipótesis, que la representación implica una construcción. En el caso de la "Nueva Novela Histórica" conlleva dos procedimientos, la deconstrucción de un hecho discursivo y la construcción mediante la escritura y la narración.

La pregunta inicial es: ¿Qué se representa?. La novela de Bonasso representa un imaginario social con una finalidad superior, que es la comprensión de una identidad. Coincido aquí con la caracterización de Bronislaw Baczko ${ }^{3}$, quien sostiene que los imaginarios sociales son sistemas de representaciones que fijan los valores y normas de la vida social. A través de estas referencias específicas en el sistema simbólico, una colectividad designa su identidad elaborando una representación de sí misma; marca la distribución de los papeles y las posiciones sociales y fija ciertos modelos comunes. En el centro del imaginario social se encuentra el problema del poder y de las representaciones fundadoras de legitimidad que le dan un sentido.

En el entramado textual la lectura descubre un imaginario social que sustenta los siguientes tópicos.

- La masculinidad depende de tres condiciones: "vago", "burrero" y "mujeriego", y responden a las características del porteño de principios de siglo, una imagen gardeliana incorporada al gusto y al saber popular.

- La honorabilidad del hombre se apoya en tres valores, "gratitud", "verdad" y "honor" y sobre todo en su pertenencia a la institución militar. Esta creencia popular que le asigna prestigio a la institución le da sentido de pertenencia a cada individuo. 
- La patria exige "sacrificio", "entrega" y "servicio", que son los justificativos éticos de todas las acciones de violencia. Esta entrega, que se resume en un sentimiento de "patriotismo", proviene de la ideología decimonónica que sustentó los movimientos de independencia. En ese marco, se muestra la intención de "fundar una República". La idea de fundación encubre la negación de la historia institucional y justifica el "orden" que suprime el "caos".

- El conflicto no es de clases sino de poderes entre dos términos políticomilitares. El poder político está vinculado a la retórica y a la mística, implica convencer. El poder militar se apoya en la violencia pero como medio para alcanzar un bien supremo: el orden. El justificativo ético de la violencia es el concepto de patria y el pragmático es el apoyo del "pueblo". Se esboza aquí la teoría de los dos demonios: los "delincuentes subversivos" vs. "fuerzas legales del orden" y también la idea de que los golpes de Estado se producen con el apoyo de la sociedad civil.

A partir de la idea de que los universos simbólicos ubican los acontecimientos colectivos dentro de un eje temporal que incluye el pasado, el presente y el futuro ${ }^{4}$, el pasado apela a la memoria colectiva, en tanto el futuro es un marco de referencia común para la proyección de acciones individuales. Así los hombres se vinculan con sus antecesores y sucesores. A su vez, el presente nos señala hoy un problema cuya simiente está esbozada en el texto: la democratización ha abarcado los aspectos institucionales pero aún se requiere una sólida democratización de la sociedad.

Si pensamos que el texto dice y explicita presencias, pero también calla, $y$ en los silencios se leen las ausencias, podemos hacer esta reflexión: la novela cuenta la historia de vida de Jaime Dri, una biografía privada imbricada con la vida pública, representada por el movimiento Montoneros. El centro de interés del relato es este grupo, sin embargo omite los conflictos entre diferentes organizaciones dentro del peronismo. Su selección del discurso histórico construye también una mística, una idealización de montoneros fundada sobre los siguientes valores:

- Vivir al servicio de la organización y sus ideales, ya que la vida privada está sometida a las metas colectivas. 
- La solidaridad es condición primera entre los integrantes de la organización.

- El móvil del accionar de Montoneros es cambiar la historia de la República, no su fundación.

- Combatir hasta la muerte, no por la patria a fundar en abstracto sino por la necesidad concreta de cambiar la historia. Por lo tanto, el sostén del accionar de un militante son sus ideales superiores, la mitificación de la política que los ubicó en el hipotético lugar de "superhombres".

- El poder de Montoneros se apoya en el saber, en su condición de intelectuales.

- Los montoneros representan los intereses del pueblo y los militares sólo de la Institución y la oligarquía. Así, este texto invierte la direccionalidad de la lucha, expresada por los discursos militares.

Una cuestión central es que la concepción de la realidad política de militares y montoneros está basada en palabras comunes a ambos, como patria, guerra, pueblo, pero su contenido semántico es muy diferente. Mientras el discurso de los militares registra un rasgo claro de autoritarismo en el monólogo de Massera, donde expresa la doctrina del llamado "Proceso", la posición de los montoneros abarca un espectro que se reduce a los "quebrados" y "no quebrados". La fidelidad al partido representa el "ser" porque une todos los tiempos del sujeto. El testimonio de Tucho, la entrevista, su carta a Galtieri, explicitan la ideología partidaria y la visión del mundo de una generación que consideró que el respetar las ideas podría conducir a la revolución que cambiaría la realidad; ésa era su utopía.

Como ominoso telón de fondo, la violencia es el factor de poder más sólido, que invade incluso la esfera privada y produce la "desterritorialización" del sujeto, que se manifiesta en los "desaparecidos", "exiliados", "muertos" y sobre todo en los "traidores". Mientras tanto, la única resistencia a la represión es la prensa que desde el exterior se muestra como un instrumento cierto de defensa de los derechos humanos, capaz de enfrentar a la dictadura desde la esfera pública.

En resumen, he identificado en este trabajo los diferentes sectores y roles que conforman el mundo de la ESMA y de la Quinta de Funes. Cada uno se 
sustenta sobre una percepción del mundo que depende de una ética. El lector descubre los principios que orientan las conductas de los personajes, pero siendo ésta una novela testimonial, se transforman en personas claramente identificables que trascienden los márgenes de la ficción pues provienen del mundo real. Sin duda, la lectura obliga a volver sobre la historia para buscar explicaciones, para evaluar o aún enjuiciar. Sin embargo, una comprensión de esta novela jamás permitiría justificar el proceder de los militares, tampoco de los quebrados y menos aún de los jefes montoneros. Lo heroico de Dri o Tucho es su resistencia al poder del dominador, sostenida por ideales como la libertad, la vida, la justicia para el pueblo; pero en Recuerdo de la muerte nunca se justifica nada que ponga los intereses individuales por encima de los colectivos.

El texto contiene una evaluación de la organización Montoneros, su trayectoria y sus líderes, que se discursiviza en el juicio a Tucho y su sentencia, pero que deja abierta otra sentencia, la del lector que conociendo la historia puede sentir la injusticia. La escritura coincide con la lectura en el paratexto: el autor realiza allí su evaluación de Firmenich y otros jefes montoneros. El relato configura su temporalidad en el pasado, el presente y el futuro; ingresa en la historia quebrando el absoluto cultural del mito.

El texto se vuelve sobre su propia escritura y define su objetivo: "Es un libro contra el olvido" que "muestra, no demuestra", en el que "todo lo que se dice es rigurosamente cierto..." La definición de lo testimonial es concluyente y se amplía en su referencia a la literatura en general: "Crearemos nuestra literatura, no conversando contínuamente de literatura sino escribiendo en orgullosa soledad libros que encierran la violencia de un cross a la mandíbula " (pág. 445), párrafo que concluye con la cita de la famosa frase de Roberto Arlt. La novela descansa, claramente, sobre un recurso testimonial que provoca un efecto político.

El texto abierto no lo es sólo por su estructura o su configuración discursiva, sino también por lo que dice: "No se puede construir una genuina convivencia democrática sobre cimientos de inseguridad y vergüenza”. (pág. 445) Deja abierto un desafío que se proyecta sobre el futuro. 
Así es como Recuerdo de la muerte es una novela de los ochenta si atendemos a su contexto de producción, pero en su contexto de recepción pueden señalarse dos momentos. Por un lado, la lectura contemporánea a su primera edición y por otro, la lectura de los noventa, que se encuentra frente a una "edición definitiva" de 1994 que incluye a mi criterio el capítulo que la reinserta en el circuito de la crítica y en otros modos de leer, "Paredón y después".

Este capítulo permite, entiendo, reubicar a la obra como una novela de "fin de siglo": traspone la denuncia o la nostalgia del pasado, evalúa la historia, para darle una función política en el presente. La escritura revela su praxis en la lectura. Desde la autorreferencialidad el texto muestra la dialéctica entre escritura y lectura, entre producción y recepción.

Una novela testimonial como Recuerdo de la muerte no dice desde el margen sino desde otro lugar de poder, el que otorga la palabra menos metaforizada, la amplitud de su público y la popularidad de los autores alcanzada en el ámbito del periodismo y los medios de comunicación.

\section{II - La memoria en donde ardía}

\section{La novela entre lo autobiográfico y lo testimonial}

La memoria en donde ardía es una novela conformada en la polifonía y en la transposición de otros géneros que dialogizan y son recontextualizados en un texto sin clausura. Así es como se pueden identificar: la autobiografía ficcional, la novela policial, el relato testimonial, el relato periodístico, la carta, el diario. Todos ellos, sin embargo, con sus particularidades textuales están al servicio del discurso testimonial cuyo sentido se encuentra en su función política.

De este modo, la nota que inicia la lectura se constituye en un paratexto orientador, en tanto explicita el género "novela" en el que el autor clasifica a su 
obra y reafirma así la convención de ficcionalidad. La ficción alcanza su mayor grado de manifestación en el protagonista que se presenta como personaje creado en cuanto a su nombre propio. Sin embargo, está acompañado en su accionar por otros, con referente en otros discursos: el periodismo y la historia, y con existencia en el mundo real: las Madres y las Abuelas de Plaza de Mayo, cuya imagen abre la obra.

La escritura trasciende los límites del hecho histórico de un espacio y un tiempo para extenderse a otras dimensiones, cuyo común denominador es la transición de la violencia a la impunidad, de las dictaduras a las democracias.

Esa nota inicial rubricada por el autor actúa como un nexo entre la escritura y la lectura; identifica una clase textual: la autobiografía, el "relato de amor", metáfora abierta a la descripción y la novela testimonial cuyo antecedente referencial es Recuerdo de la muerte, obra que constituye otro punto del diálogo interdiscursivo que la lectura puede poner en práctica.

El autor esboza también aquí su tesis, enunciado que el texto completa en la imposibilidad de su clausura:

* La función política de la narración es generada por la "memoria", que es una forma de "justicia" mediatizada por la escritura (la novela) y por el cuerpo (las Madres y las Abuelas)

* El pasado se hace presente en la escritura, para decir sobre la derrota que sin embargo señala la utopía colectiva de ideas irrealizadas.

Como totalidad, la novela presenta la estructura propia del relato policial. En el plano funcional se organiza en tres secuencias: el delito, la investigación o búsqueda, y el descubrimiento, con un notable registro de indicios que el lector recupera para construir la verdad.

La revisión de los títulos de cada una de las partes en que se organiza la novela es una marca textual que orienta el análisis en este sentido. La primera parte, llamada "Once años no es nada", voz popular recontextualizada, destaca la importancia del pasado sobre el presente. El transcurso del tiempo no ha separado las dos instancias, lo que explica la búsqueda y el título de la segunda parte, "Laberinto", que representa el difícil recorrido que sigue el protagonista en su procura de la verdad para explicar el presente y el futuro. Es 
así como el resultado es la "Resurrección", nombre de la tercera parte, que señala el renacer a una nueva vida.

La base fundante de la búsqueda está constituida por el relato testimonial y el relato periodístico. Por otra parte, el lector se encuentra frente a una alternancia de diferentes voces narrativas, que son marcas de la autobiografía. Asímismo, la obra puede considerarse una "novela romántica" que conserva los caracteres esenciales del género en la literatura argentina: el amor y la muerte como temáticas vinculadas inexorablemente a la política. Podríamos mencionar, a título de ejemplo y como un caso fundante, a la novela Amalia, de José Mármol.

Me ocuparé especialmente en este trabajo del análisis de dos aspectos: el relato testimonial, su configuración, contenido y función; y el lector implícito.

\section{Relato testimonial y sujeto narrativo}

Las voces narrativas producen un desplazamiento de la tercera persona e introducen la primera o la segunda persona gramatical. El lector se encuentra ante la autobiografía ficcional y el diario que ubica al personaje en su presente de enunciación y en la evocación íntima.

La palabra del autor entra en el campo de representación en el mismo plano que la del personaje. Desde esa voz el objeto de representación es el pasado pero con una orientación valorativa dada por el presente. La contemporaneidad también es entonces un núcleo problemático. Es así como la focalización deja de ser individual para incorporarse a lo colectivo y es precisamente cuando la escritura constituye un acto de resistencia.

Esta presencia del sujeto en la escritura introduce además lo autobiográfico. En esta obra se representa, como lo señala Nicolás Rosa, "intersticialmente entre el discurso de la Historia (por su efecto memorialístico, su relación con un cierto pasado y sobre todo por su ficción de credibilidad) y el discurso del Sujeto, por el espacio egocéntrico que parecía instaurar". 5 
En conceptos de Philippe Lejeune, en su ensayo "El pacto autobiográfico" (Ver Capítulo I. 3), el espacio autobiográfico surge del deseo de los escritores de que en su obra se lea la verdad de su escritura y de su vida. Esto sitúa a la autobiografía ante el problema de la ficción. La competencia del lector que es capaz de componer el mundo de Sergio y asimilarlo al del autor, así como reconocer los hechos, los personajes y los ambientes que formaron parte de su vida le otorgan al texto el carácter autobiográfico. Se trata de un pacto constituido por elementos textuales y extratextuales que el lector puede vincular y reconocer, para establecer una identificación entre narrador-autor-personaje.

En la obra de Bonasso la autobiografía adquiere carácter testimonial; más que como género, lo es por intención y efecto. Es una voz que se une a la de otros personajes para relatar con detalles, con una fuerte presencia de la subjetividad, un hecho del pasado. El texto materializa la memoria de un narrador, protagonista, testigo y juez. Es un espacio escrituraria desde el cual se resiste al olvido.

En este sentido, en el capítulo II, la expresión "y es un segundo. Y se abren las puertas del espacio y también del tiempo" (pág. 27), marca un umbral tempo-espacial focalizado por un yo narrador en primera persona. Sin embargo, el narrador en tercera persona describe la ciudad desde el punto de vista del personaje, con detalles verificables en el mundo real que constituyen el marco referencial en el que se sitúan los hechos. De esta manera, se otorga a la historia un grado de factualidad.

En este movimiento del narrador, la historia particular se abre a la pluralidad cuando aborda la descripción del exilio en tercera persona del plural. En esta focalización del sujeto de la enunciación el relato es testimonial y da cuenta de una subjetividad colectivamente verificable. Su vida encuentra vinculación con un mundo más amplio y con referentes en otros discursos no ficcionales. Se trata de un sujeto escindido en yo-él-tú-nosotros. Es la fuerza del yo que se escribe a sí mismo como otro él y que en ese acto incluye al lector en un equivalente nosotros-ellos. El tú no es un extraño a sí mismo sino un yo que se repliega, se vuelve sobre su propia conciencia y la interpreta. Lo otro introduce lo colectivo. En este procedimiento lo particular es paradigmático. 
Además, es importante señalar que el relato testimonial tiene en la novela distintas funciones:

*Instala la narración en el pasado: "once años antes".

* Constituye un recurso de escritura que aporta partes de una verdad que el lector debe reconstruir junto al protagonista.

* "La historia de H" asume la categoría de un relato testimonial enmarcado que puede verse como una historia paralela a la de Sergio .

El texto adquiere, entonces, características de historia de vida, de "biografía", pero habla en su diálogo con la "autobiografía", sobre los destinos de la generación de la década del setenta.

Los relatos testimoniales que están enmarcados y que pueden ser identificados son los del Chupado, el Desaparecido, Lomuto y "H". Analizaré cada uno de ellos.

* El testimonio del Chupado reitera lo que el autor ya había anticipado: la relación intertextual con su obra anterior Recuerdo de la muerte, característica propia del relato testimonial, según Ana María Amar Sánchez. ${ }^{6}$ Por otra parte, la información hace referencia a espacios y nombres con existencia en el mundo real y en otros discursos. Se produce entonces una expansión del texto que apela a la competencia del lector, quien para comprenderlo debe ponerlo en diálogo con otros que circulan en el campo escrituraria de la Argentina de fin de siglo (Nunca más, por ejemplo).

* El testimonio del Desaparecido completa al anterior sosteniendo la continuidad de la investigación, pero además explicita el texto leído por el autor-lector, planteando así un pacto de lectura. Además, señala la función del testimonio: la denuncia. El acto de escribir es una forma de hacer justicia, une el presente al pasado manteniendo viva la memoria, entendida como una construcción activa.

* El testimonio de Lomuto tiene en el texto una doble función. Por un lado, aporta datos sobre el personaje y crea expectativas en el lector mediante un procedimiento elusivo y alusivo. Está al servicio de la intriga propia de la novela policial. Por otra parte, es un avance en la investigación policíaca, actúa como un recurso para la reconstrucción del pasado. Se trata de una "historia de vida", que como dije antes puede leerse en paralelo con la de la novela. Biografía y 
autobiografía se presentan ante el lector en el marco ficcional de la novela. La memoria vehiculiza la construcción del "yo", que es otro y por consiguiente funda la alteridad.

El relato introduce un personaje que completa el espectro de los destinos de la generación que en la década del setenta tuvo tanto protagonismo político en la Argentina; el opositor de "H" es Sergio. Representan, respectivamente, la versatilidad de las ideas y la ideología persistente; el materialismo e individualismo y la conciencia social; la negociación con el poder y la desterritorialización física e ideológica (el exilio).

Es así como la ficción ofrece una alternativa para la comprensión del mundo: repensar la historia desde las memorias ocultas o silenciadas, una revisión del pasado desde múltiples perspectivas, a saber:

- Bordenave vive en el pasado, muestra la frustración frente a la derrota. Su presente está ocupado sólo por el pasado: su acción es la investigación y la construcción del archivo como un "lugar de memoria" que otorga al periodismo un valor equivalente al del saber histórico. Es el registro de las huellas y de la temporalidad abierto a la interpretación y a la actividad crítica.

- Goyo representa la nostalgia por una militancia que pertenece al pasado y que opera a contramano con el presente al punto de crear situaciones paródicas.

- Los testigos, cuya misión en el presente les viene del pasado: la denuncia como resistencia a la impunidad.

- La abuela Leonor representa una alternativa de justicia que se ejerce con la lucha y el compromiso del cuerpo colectivo.

- Palavicino-Wilkins es un hombre sin identidad y que mantiene una constante: su obsecuencia con el poder.

- Los militares, que conservan la esperanza de repetir la historia.

Este relato de Lomuto enmarca el testimonio de "H", último estadio de la búsqueda orientada por la palabra. Luego, el protagonista iniciará otra: la búsqueda con el cuerpo, donde el pasado dejará nuevamente las marcas de la represión.

\section{El lector implícito}


El texto prefigura un lector mediante dos estrategias discursivas: la interrogación y la argumentación. Las preguntas interpelan al lector para situarlo en el rol de evaluador del pasado a partir del análisis del presente cotidiano. Se detiene en una visión de la juventud de los setenta, con un tono nostálgico:

“CCómo harían los maduros para ser románticos dentro de esas licuadoras estrepitosas?... ¿Adónde carajo se iba el ritual de la manito?" (pág. 84).

La interrogación sitúa al lector en el contexto político de la década del ochenta, en la "transición", con una pregunta que evoca una inquietud colectiva:

“¿Quién votó a estos papanatas?... ¿Y quién va a votar a un peronismo descafeinado?" (pág. 58).

La primera persona del plural generaliza un pensamiento que expresa el sentir, la idiosincrasia de los argentinos que constituyen una sociedad aún no democratizada, en la que no se ha desarrollado el ciudadano:

"De acuerdo con su abogado, se negó a prestar declaración, amparándose en esa otra veterana tantas veces violada, que seguimos Ilamando Constitución" (pág. 65).

La argumentación sobre una tesis que abarca al yo-nosotros en un procedimiento que se apoya sobre esa transformación de la persona gramatical y que involucra así al lector: "El pasado es mi identidad, mi columna vertebral" (pág. 339). Ése es el sentido del relato, y de la búsqueda: recuperar el pasado como clave del presente y del futuro colectivo. El lector se reconoce en el plural y es invitado a compartir la tesis del autor: "Porque nuestra casa es la historia. Y a nuestra casa acabamos de regresar" (pág. 340). La búsqueda es la de las Madres y de las Abuelas, la misma que la sociedad ha silenciado.

Se suscita así una relación de empatía entre lector-texto-autor, que favorece un pacto de lectura en el que la ficción produce una aproximación al mundo real, un conocimiento que subyace en el imaginario de la sociedad. Esta condición es propia de lo que llamamos "Nueva Novela Histórica". 


\section{Narrativa metaficcional}

La cultura contemporánea se destaca por su interés en la función del lenguaje como constructor del sentido de la realidad cotidiana. En esta línea de pensamiento ya no se sostiene la simple noción de que el lenguaje refleja pasivamente un mundo coherente y objetivo. Por el contrario, esa relación es compleja, problemática y está regulada por convenciones.

Como consecuencia, se desarrollaron en los últimos veinte años lecturas críticas que recuperan la condición metaficcional de la narrativa. No obstante, aunque el término metaficción es nuevo, la práctica es tan antigua como la novela, tanto que le otorga su identidad. Así es como existe un lenguaje de ficción, que Mijail Bajtín define como dialógico, y la metaficción simplemente hace explícito este potencial de la novela. (Ver Capítulo I).

La metaficcionalidad es altamente consciente de un dilema básico: si la intención es representar el mundo, el escritor comprende rápidamente que tal cual es no puede ser representado. En la ficción literaria es posible, por lo tanto, solamente representar los discursos del mundo. El común denominador de la escritura metaficcional es que crea una ficción y simultáneamente establece principios sobre la creación de la ficcionalidad. Estos procesos coexisten en una tensión que quiebra la distinción entre creación y crítica, y la sumerge en los conceptos de interpretación y deconstrucción.

La lectura de la obra de Bonasso desde esta perspectiva me permite argumentar que se trata de una novela metaficcional pues en la sucesión de novela-relatos enmarcados, el lector lee un enunciado: la narración materializa la memoria para dar lugar a la acción, pero siempre al servicio de la búsqueda de la verdad como una forma de hacer justicia y de refundar el futuro.

La escritura presenta la multiplicidad de relaciones entre el pasado y la contemporaneidad, pero la fuerza autobiográfica destaca una propuesta: no se plantea una nostalgia del pasado sino un camino laberíntico de aprendizaje para resurgir de la derrota, un planteo para crear una sociedad diferente en la que el amor es una alternativa cierta para "derrotar a la soledad y a la muerte" (pág. 343). 
En este marco y como narrativa metaficcional, se leen ciertos presupuestos, que pueden enunciarse en los siguientes términos:

- La novela polifónica e intertextual es narración de narraciones, atraviesa la temporalidad y concentra en la escritura el pasado, el presente y el futuro. Borra los bordes textuales; no existe la clausura sino una expansión que los pone en diálogo para construir un mundo posible, tesis que se resume en el epígrafe: "La realidad es el todo".

- La novela testimonial abre el texto a otra dimensión que pone la literatura en contacto con la historia porque instala la memoria colectiva. La literatura de fin de siglo dice y devela las memorias silenciadas y desde allí el lector es invitado a representar el pasado. Sin embargo, como la historia no es un saber inocente, intervienen en su construcción diversos factores de poder. ¿Cuáles son? Podemos identificar su recurrencia en el texto y en la realidad de la Argentina de fin de siglo: el periodismo, el testimonio de los testigos, y las Madres y las Abuelas de Plaza de Mayo, cuyo poder está en la palabra y en el cuerpo, con lo que rescatan del olvido una parte del pasado.

- La Nueva Novela Histórica se constituye en una manifestación de la cultura que descubre, junto con otras expresiones, una realidad silenciada. 


\section{* Notas}

${ }^{1}$ Scarry, Elaine. The Body in Pain (opus cit), pág. 51.

${ }^{2}$ En su artículo "Segmentación del texto en unidades del discurso (Boletín de Lingüística. Universidad Central, Caracas, Venezuela, 1995), la investigadora María Laura Pardo define al párrafo semántico como una unidad de análisis del discurso que se aplica al contenido y sirve para detectar las estrategias semánticas usadas por el que escribe.

${ }^{3}$ En su libro Los imaginarios sociales. Memorias y esperanzas colectivas. Buenos Aires, Nueva Visión, 1984.

${ }^{4}$ Sarlo, Beatriz. "Cuando la política era joven”. Punto de Vista N 58, pág. 19.

${ }^{5}$ Rosa, Nicolás. El arte del olvido, página 33.

${ }^{6}$ En su ensayo La ficción del testimonio. 
Capítulo III

Un relato contra el olvido:

José, de Matilde Herrera 


\section{I - Un texto particular}

José, de Matilde Herrera, ofrece al lector una configuración muy particular. Las cartas manuscritas, las fotos, los documentos quiebran la monotonía de la letra. La heterogeneidad que caracteriza al texto incluye otros tipos discursivos bajo el título de "testimonio". Sin embargo, la narración es la modalidad organizadora y alterna la primera persona del singular con la primera del plural. Sin duda, esta construcción que se observa a primera vista prevé a un lector activo al que invita a cooperar en la construcción de un relato que se descubre como totalidad, pues aunque los diferentes tipos discursivos señalan diversos caminos de lectura, todos conducen un único centro: la historia de vida de José.

Este prolegómeno genera muchas preguntas que mi lectura tratará de despejar. La primera es: ¿Por qué esta historia de vida es el centro del relato? La respuesta se encuentra también en forma inmediata en la carta que cumple la función de prólogo. Me detendré luego en su análisis ya que abre varios problemas de reflexión teórica, tales como cuestiones acerca del género, la función política del texto, su inserción en el campo literario y planteos de orden metaficcional.

Esta obra forma parte del corpus de mi investigación porque en ella se representa la década del setenta en la Argentina. A partir de esta afirmación surgen otras preguntas clave: ¿Cómo se representa? Responder implica realizar un relevamiento y explicación de las estrategias escriturarias y también buscar aquello que el narrador calla. Sin duda, para comprender los silencios es necesario encontrar respuesta a otra cuestión: ¿Quién narra y cuándo lo hace? El procedimiento no se plantea como una búsqueda o un descubrimiento sino como una co-producción entre texto-lector. Es así como se hace necesario ponerlo en relación con otras obras, en este caso Nunca más, Recuerdo de la muerte y La Voluntad, con las que se establece un diálogo muy productivo. Puesto en esta perspectiva, José ingresa en otras dimensiones de sentido y encuentra su horizonte en lo público y en lo político. 


\section{II - Una "historia de vida"}

Como he afirmado anteriormente, se trata de un relato al que el lector puede ingresar por diferentes caminos; en todos los casos lo guía una cronología que organiza la narración como "historia de vida".

Una posible vía de acceso al texto son las fotos, a las que podríamos considerar como relatos susceptibles de análisis. En tal caso estaríamos frente a un álbum familiar. La palabra completa el sentido de las imágenes, las contextualiza y comenta para actualizar el recuerdo. Esta es una lectura parcial que se centra en lo privado y en lo individual, pero que para dar cuenta de la totalidad debe ponerse en relación con el prólogo y con los otros textos que configuran el entramado de la obra. Es entonces cuando se genera una pregunta acerca de la funcionalidad del álbum y de la significación que tiene esta exposición de la vida privada.

Me atrevo aquí a dar una respuesta provisoria que se completará a medida que avance en mi reflexión: entiendo que es una forma de resistencia, aquella que eligieron las Madres de Plaza de Mayo; oponer la vida familiar a la voluntad estatal de represión es una forma de mostrar la deshumanización del régimen en concordancia con la creciente "humanización" de los montoneros, en este caso representada por José. Es por lo tanto una forma de deconstrucción del discurso estatal, fundado sobre valores como la familia, la paz y la patria según he probado mediante el análisis político del discurso de los militares en Recuerdo de la muerte (ver Capítulo II).

Otro camino de abordaje del texto está conformado por las cartas, que manuscritas y transcriptas se constituyen en documentos probatorios y contribuyen a crear un pacto de veridicción con el lector. Conforman en su conjunto una estrategia escrituraria para contar la historia del protagonista en tanto se presentan en secuencia cronológica, con excepción de aquella que abre el texto, la primera que acompaña al prólogo, que es paradójicamente la última escrita por el protagonista.

La carta es un recurso propio de la novela sentimental, pues lleva los hechos al plano de la intimidad, vehiculiza una relación yo-tú. El circuito de 
comunicación se acota y lo privado ya no alcanza sólo a lo familiar, como es el caso del álbum de fotografías, sino que establece un vínculo en el que el tú está especialmente representado, en este caso por la madre. Es la madre desde su sentir, desde su subjetividad, quien selecciona, ordena y así construye un relato de la vida de su hijo. La memoria discursiviza el recuerdo, pero cuando las palabras huelgan se presentan los dibujos o los poemas que completan la personalidad del protagonista.

El relato se construye en torno de una persona, José, cuya acción preponderante es la militancia política, pero también está su escritura. José tiene una faceta pública y política que el lector puede recuperar en sus cartas. La presencia del yo es allí muy abierta; el género epistolar permite un margen de intimidad que trasciende el relato de los hechos para mostrar su sentir frente a los acontecimientos de la vida. En el gesto de abrir la historia de la vida familiar y la intimidad del hogar para que ingrese al mundo de la narración se concentra toda la fuerza de su denuncia. El lector se encuentra con que José niño, joven, hijo, hermano, amigo y padre, por ser también militante y líder político, es el "desaparecido". El efecto es sin duda directo al sentimiento del lector. No sólo a su sensibilidad sino sobre todo a su intelecto. Nadie podría dejar de preguntarse si la culpa de José y de otros jóvenes como él fue tan sólo creer en la revolución para alcanzar justicia, derechos y dignidad para todos. La violencia de la represión, cuyo saldo son miles de muertos y desaparecidos, no alcanza, desde esta perspectiva, justificativo alguno.

Así, se deconstruye nuevamente el discurso de los militares y se neutralizan las razones del llamado Proceso de Reorganización Nacional explicitadas por los discursos de Massera y Acosta en Recuerdo de la muerte (ver Capítulo II). Por su parte, Eduardo Anguita y Martín Caparros transcriben en La Voluntad el Acta con la que se deponía la Constitución y que anunciaba entre sus objetivos (...) "la vigencia de los valores de la moral cristiana, de la tradición nacional y de la dignidad del ser argentino; la vigencia de la seguridad nacional erradicando la subversión y las causas que favorecen su existencia; la vigencia plena del orden jurídico y social (...) Además del Acta, en la mesa de caoba de la sede militar había un crucifijo y una biblia". ${ }^{1}$ Pero, tal vez la lectura 
más abarcadora sea aquella que pone en diálogo la obra de Matilde Herrera con el Informe de la CONADEP, Nunca más.

En el prólogo a Nunca más, Ernesto Sábato enuncia algunas ideas que me interesa mencionar: la "teoría de los dos demonios", la angelización de las víctimas a partir de su despolitización y de la negación de su condición de revolucionarios, la instauración de una culpa colectiva y la ruptura de lazos solidarios. Todos estos aspectos parecen estar al servicio de la justificación del horror.

Dice Sábato: "Durante la década del setenta la Argentina fue convulsionada por un terror que provenía tanto de la extrema derecha como de la extrema izquierda". ${ }^{2}$ El texto postula así un terror que convulsionó a la sociedad versus un terror planificado; el primero convocó al segundo, que es infinitamente peor. De este modo formuló la teoría de los dos demonios, en torno de la cual estimo es válido hacer una digresión.

La teoría de los dos demonios se plantea en el libro de Ernst Nolte titulado Después del comunismo ${ }^{3}$. Nolte define al siglo $\mathrm{XX}$ esencialmente como un espacio temporal en el que se desarrolló una guerra civil entre nazismo y comunismo, esquema que consiste en afirmar que esos son los dos rostros demoníacos de la historia mundial del siglo XX.

En la Argentina esta misma teoría constituyó el horizonte conceptual en el que se elaboró el Nunca más: la acción de dos fuerzas violentas extremas abisman en el caos a una sociedad inocente. José Pablo Feinmann ${ }^{4}$ afirma que estas relaciones fueron establecidas por Ernesto Sábato, a quien define como un referente de la sociedad y como responsable de instalar en ella el punto medio de la inocencia. Sin embargo, sobre el fin de siglo algunos escritores sostienen que todos los golpes han sido cívico-militares, por lo que la sociedad deja su posición neutral. Tal es el caso de Horacio Verbitsky, quien describe la complacencia de la clase política con el golpe, el colaboracionismo de la Iglesia y la participación empresarial. En su ensayo Militares, civiles y el mundo ${ }^{\mathbf{5}}$, Verbitsky sostiene además que si bien hubo episodios de resistencia a la dictadura desde la prensa y las Madres de Plaza de Mayo, lo que no se articuló fue una resistencia organizada que forzara su retirada. También hubo otros 
sectores que resultaron víctimas del terror y se vieron impotentes para dar una respuesta.

En franca oposición con la postura de Sábato, Rodolfo Walsh, antes que la teoría de los dos demonios encontrara una postulación en la sociedad argentina, demuestra cómo la Junta se ampara en ella porque justifica su accionar y permite definir la lucha contra la subversión como una guerra. Sin duda, no fue una guerra sino una acción terrorista del Estado. Así lo expresa Walsh: "Las $3 A$ son hoy las 3 Armas, y la Junta que ustedes presiden no es el fiel de la balanza entre 'violencias de distintos signos' ni el árbitro justo entre 'dos terrorismos', sino la fuente misma del terror que ha perdido el rumbo y sólo puede balbucear el discurso de la muerte". 6

En su libro, Matilde Herrera cuenta la historia de vida de su hijo José, pero el lector se encuentra con una ausencia, se silencia la violencia de los grupos militantes (Montoneros, ERP, etc.) y sólo se presenta una violencia: la del Estado. De este modo, su obra puede leerse como una respuesta al prólogo de Sábato: no se trata de una guerra, sino de terrorismo, porque además elige una manifestación de la violencia, aquélla que transforma al ser humano, hijo, hermano, padre, en "desaparecido". Esta condición tiene dos instancias: primero se disuelven los vínculos que constituyen su "ser", la familia, los amigos, la identidad, para culminar abarcados por una condición, la de militante, y finalmente es el "ser humano militante" el que ingresa a la categoría de "desaparecido".

En esta narración de Matilde Herrera subyace otra perspectiva del "terrorismo de Estado", diferente de la que Sábato expresa cuando insiste en destacar la condición de "seres humanos" de las víctimas. Así, Sábato construye lo que se ha llamado "angelización", 7 quitándoles su condición de militantes políticos y de revolucionarios. Escribe en el prólogo: "En cuanto a la sociedad, iba arraigándose la idea de la desprotección (...) apoderándose de unos el miedo sobrecogedor $y$ de otros una tendencia consciente o inconsciente a justificar el horror: 'Por algo será' se murmuraba en voz baja”. Así, frente al "por algo será", la respuesta de Sábato es "no fue por nada". Su valoración recae sobre el atributo culpable o inocente y no sobre la condición de víctima. Desde este enjuiciamiento realiza una tipificación de los 
desaparecidos, al inferir que los revolucionarios militantes políticos son diferentes de los sindicalistas, de los obreros, de los estudiantes que hacen asistencialismo en las villas.

De este modo separa a las víctimas de su pertenencia a un movimiento organizado, revolucionario. Dice: "Todos, en su mayoría inocentes de terrorismo o siquiera de pertenecer a los cuadros combatientes de la guerrilla...". Se puede leer aquí una clara intención que justifica la represión, ya que hubo víctimas inocentes, porque los culpables son los otros, los que murieron "por algo", por ser militantes políticos revolucionarios.

También José es una narración, como he dicho antes por sus estrategias de escritura, que destaca lo "privado" y pretende ahondar en la "humanización" del protagonista, sólo que la intención es inversa: el protagonista esencialmente es un militante político en la acción y el pensamiento, un hombre de la revolución social, y el relato de Matilde Herrera acompaña su crecimiento como líder con sus experiencias y vivencias en distintos roles. No son culpables ni inocentes, son seres humanos politizados, y ésa fue la única razón de su "desaparición"; son sólo víctimas. Se desarticula una vez más la teoría de los dos demonios; la intención es explícita y no existe entonces justificativo alguno para el horror. Matilde Herrera responde al ideario de Madres de Plaza de Mayo, que luchan contra el olvido y contra la muerte como una forma de hacer justicia. Su voz y su cuerpo constituyen una respuesta concreta a afirmaciones del citado prólogo, en los que Sábato se refiere a las víctimas como "abandonados por el mundo". Disuelven con su accionar el manto de culpa colectiva que representaron estas palabras del Nunca más y restituyen los lazos solidarios por la justicia y por la vida.

Hebe de Bonafini dice: "Nosotras, nuestra lucha y nuestro dolor, los hicimos públicos y colectivos y juntas fuimos a un lugar público, la Plaza, para que nos viera todo el mundo. Colectivamente buscamos a los asesinos y pedimos por los hijos (...) A los desaparecidos los consideramos todos iguales, nunca los diferenciamos (...) Los reivindicamos por revolucionarios. Nunca pensamos que se los llevaron por tontos (...) Eran adultos y la tenían reclara”.

La autora de José narra desde su condición de madre y desde allí pone en duda la eficacia de otras narraciones, obligando a repensar la historia 
transmitida desde otras disciplinas y planteando una continuidad histórica entre vivos y muertos y la responsabilidad de los vivos para defender la memoria de los muertos. La madre-mujer es depositaria de la memoria colectiva. Dice en su carta-prólogo: "Quiero que permanezca tu palabra, la de tus hermanos, y a través de ustedes, la de todos aquellos que fueron secuestrados durante la dictadura militar. Los que están desaparecidos, pero que no han de desaparecer jamás (...) Éste es el aporte que puedo brindar a esa memoria colectiva tan importante para el crecimiento de nuestra patria". (Páginas 13 y 14).

Creo que debe hacerse aquí una consideración acerca de "la memoria". He tomado los conceptos de memoria, recuerdo y olvido enunciados por Pierre Nora y J. Yerushalmi (ver capítulos I y II). Ante la narración de Matilde Herrera creo necesario retomar la idea de que la memoria, en tanto representación de un suceso, involucra una selección e interpretación, operaciones que en este caso particular están condicionadas no sólo por lo individual sino también por lo social, ámbito en el que puede claramente identificarse al movimiento de Madres de Plaza de Mayo, como afirmé anteriormente.

En mi opinión, es muy valiosa en este sentido la tesis de Fernando Reati, quien sostiene que la memoria personal es indefectiblemente parte de un sistema de representaciones públicas del pasado y que “... en la Argentina la memoria personal no trata de un pasado objetivo sino de un presente que queda aún por resolver". 9

La obra de Matilde Herrera, escrita en 1987, enuncia un presente en el que la justicia aún se veía como posible, en el que aún se mantenía la esperanza. Dice en su carta-prólogo: "El país que ustedes pretendían lo forjará poco a poco el pueblo que tanto amaron. Ese proyecto será levantado por todos los argentinos..." (página 14).

Hoy, ya en el fin de siglo, el lector encuentra en esta expresión un espacio en blanco para completar: se ha desvanecido la posibilidad de justicia, la generación del setenta y su proyecto han ingresado al plano de lo utópico, su acción revolucionaria es para algunos críticos una equivocación ${ }^{\mathbf{1 0}}$ y para otros la memoria de la violencia de esa época hasta podría constituir una amenaza para el futuro. ${ }^{11}$ Estas consideraciones son precisamente las que me dan lugar 
a pensar que "por algo será" que en el campo escriturario se produce este encuentro particular entre historia y literatura, entre historia y ficción. $\mathrm{Y}$ son también estas consideraciones las que me recuerdan una afirmación de Tzvetan Todorov, quien dice que "la defensa más eficaz contra el totalitarismo, que es un hecho político, es también política: es la democracia activa (...) una democracia que acepte ser criticada y transformada desde dentro, pero que al mismo tiempo se muestre intransigente con sus verdaderos enemigos. "12

Me pregunto entonces cómo hará esta democracia para desarrollarse plenamente si aún no ha desenmascarado a sus "verdaderos enemigos", si no realiza una revisión del pasado sin temores, sin ocultamientos, si no transforma las acciones políticas en acciones morales. Coincido plenamente con Todorov cuando dice que son éstas las que "aportan aquello que el mejor de los regímenes políticos no puede jamás engendrar, sino sólo hacer posible: un excedente de humanidad". ${ }^{13}$

Sin duda la "guerra sucia" ha terminado, pero esta obra de Matilde Herrera, como las de Miguel Bonasso, tienen una nueva manera de librar combate, que no ha finalizado: se produce desde otro lugar, el de la memoria, el del relato que busca comprender el pasado para leer al fin esa página de la historia.

Como ya anticipé, José es un texto particular. En mi opinión, lo es entre otras razones porque plantea al lector algunas cuestiones acerca del género. Sus características podrían llevarnos a decir que se trata de una autobiografía, sin embargo el centro del relato es la historia de vida de José, por lo que nos pone en contacto con la biografía, y yendo aún más lejos, su conformación destaca tipográficamente al testimonio.

La obra de Matilde Herrera pone en juego los elementos propios de la autobiografía enunciados por Lejeune (Ver Capítulo 1.3). En efecto, se trata de una narración retrospectiva que asume la identidad entre narrador, personaje y autor, la que se establece en virtud del pacto autobiográfico. Tiene un carácter contractual que determina un tipo de escritura y un modo de lectura.

El texto presenta un espacio autobiográfico evidente, me refiero a la "Carta de una madre" (páginas cuarenta1 a cuarenta3), donde sintetiza toda la 
problemática del relato, el hijo desaparecido. La autora-narradora ratifica aquí su identidad con el personaje: la mujer-madre cuya acción principal es contar, para denunciar. En este gesto la escritura traslada todo el peso cultural de la significación de la madre, vinculada siempre a la esfera privada, hacia la esfera pública. Es justamente en este movimiento que la voz narradora abandona las vivencias individuales para ser representativa al hacerla extensiva a lo colectivo. Dice, entonces: "Trataría de denunciar nuestro caso que era el de miles y miles de compatriotas. Si no salvaba a mis hijos, a lo mejor podía hacer algo por algún otro hijo. Uno solo que se pudiera rescatar justificaba la lucha". (Página 399).

Situado en esta perspectiva, el texto problematiza su carácter autobiográfico y se ubica en las fronteras con lo testimonial. A la luz de esta afirmación, creo conveniente analizar algunas notas propias del testimonio, que he enunciado ya (ver Capítulo I), y observar su actualización en la obra que nos ocupa.

En tanto texto homodiegético, cuya intención es establecer con el receptor un pacto de veridicción, está enmarcado por un prólogo, un epílogo y el sujeto narrador actúa como testigo-protagonista y juez de los acontecimientos. Este sujeto comparte con el receptor una misma preocupación histórica y se eleva como una voz de resistencia al poder de la violencia de Estado, voz que por consiguiente no es individual sino colectiva.

Sin duda, la carta-prólogo constituye una estrategia de escritura con múltiples funciones:

- Establece la situación de enunciación determinando el momento histórico en que se produce el relato (mayo 1987), por lo que orienta al lector en su construcción del mundo extratextual y del campo interdiscursivo.

- Identifica al sujeto de la enunciación en el rol principal que asume, el de mujer-madre, con el cual se constituye en una voz colectiva y representativa.

- Explicita su intención, que es la denuncia mediante el testimonio y para la memoria colectiva. 
El epílogo "Seguirás viviendo" cierra esta intención del texto inaugurado por la Carta y lo hace con una estrategia discursiva que instala el problema en el ámbito público: la forma impersonal del verbo ("se presentaron", "se pidió") y la enunciación de preguntas que vinculan dos términos (José-miles de argentinos): “¿Cuál fue el destino de José; de sus hermanos y de miles y miles más de argentinos que fueron un día trasladados hacia ...?". (Página 400)

Aunque la obra se encuentra enmarcada, sin embargo el sentido se conforma en sus relaciones con otros discursos; así es como fue necesario ponerla en diálogo, por ejemplo, con Recuerdo de la muerte y Nunca más, siempre a partir de indicadores textuales. Este aspecto, la interdiscursividad, es también inherente al relato testimonial,.

Hasta aquí he demostrado que este texto reúne las características propias del relato testimonial. Sin embargo queda aún una cuestión por despejar, la subalternidad del sujeto narrador, en tanto es un elemento determinante para la modalidad de producción del discurso testimonial. En este caso es importante recuperar una noción de lo subalterno que no se identifica directamente con una marginación social.

Si entendemos la subalternidad como una perspectiva y no como una categoría, ${ }^{14}$ estamos frente a un sujeto descentrado por su posición política de resistencia a la violencia de las "fuerzas conjuntas"; se trata de la voz de una víctima sometida por una carencia, la justicia. Esta revisión ha hecho posible observar cómo lo testimonial prevalece por sobre lo autobiográfico.

Pero también es interesante señalar que el testimonio ingresa al texto además como un recurso de veridicción, como un documento citado, aunque bajo el título de "testimonio" el lector se encuentra con otras modalidades discursivas, como la entrevista y la carta. Estos testimonios no instalan un discurso dialógico sino que conforman una única voz organizadora, la del sujeto de la enunciación. Las preguntas están en función de la perspectiva ideológica de quien la formula: la narradora. Se destaca, entonces, la personalidad, los valores y los hábitos de José; profundiza sobre su condición de militante y líder y aparece en el trasfondo la situación política del país. Estas intervenciones colaboran en la construcción del "héroe" sustentado sobre sus condiciones personales y sus metas sociales, que lo hacen representativo de 
una generación. Mientras tanto, la carta de Ricardo López (página 131), muestra otra cara de la represión, el exilio, y también contribuye a fortalecer la intención final de la autora, que es contar la vida de José.

Cuando la memoria, que es sustancia y composición del relato, se apoya en documentos en los que se registra el pasado, da lugar a la biografía. La meta final de este registro es la preservación del conocimiento y la construcción de un modelo. Por eso, el desaparecido sin voz presta testimonio a través de sus dibujos, sus cartas, sus poemas, siempre organizados por la autora.

Desde esta perspectiva, es posible sostener que José es una obra de naturaleza híbrida. El lector se encuentra frente a una biografía pública, que transgrede toda posibilidad de clasificación genérica para responder al modus operandi del relato testimonial, que en términos de George Yudice es la estética de la concientización y de la solidaridad.

\section{III - Memoria del pasado}

Este análisis ha intentado demostrar la representación de la década del setenta que el texto produce. Sin embargo, permanece aún pendiente otra cuestión no menos importante, y es comprender qué dice sobre el presente de este fin de siglo esa representación. Para orientar mi lectura en este sentido creo necesario demorarme en algunas cuestiones previas.

En principio me parece oportuno recordar la idea de que el presente de la escritura condiciona el rescate del pasado, al punto de que es relevante saber cuándo se recuerda y a partir de dónde. El texto aporta este dato, "27 de mayo de 1987", y su importancia para la historia privada y pública es que "se cumplen diez años de tu estar desaparecido", refiriéndose, claro, a José. Esta afirmación tiene un gran potencial de significado para un lector cooperativo y genera además una investigación extratextual para recuperar el contexto de producción y de recepción. 
Seguramente, todos recordarán que en 1983, con la elección democrática del presidente Raúl Alfonsín, terminó el terror de Estado en la Argentina. Los hechos posteriores estuvieron signados por las marcas de los años setenta y fueron motivados por las políticas de olvido cuya consecuencia fue la exculpación de los militares condenados por los juicios de principios de la década. Los tres tiempos de la exculpación son el Punto Final, la Obediencia Debida y el Indulto. ${ }^{15}$ Ése fue el camino hacia la impunidad que instaló lo siniestro en nuestro país. Al respecto dice Fernando Reati: "En los años setenta lo siniestro consistía en la presencia en las calles del fantasma de la desaparición (...) Hoy lo siniestro consiste en la presencia en las calles de los culpables compartiendo el espacio público con la ciudadanía”. ${ }^{16}$

La impunidad elimina al victimario y con él a la víctima, por eso hoy hace sentir sus efectos sobre el imaginario social y borra las diferencias entre lo moral y lo inmoral. Se pierde el vínculo con el pasado, para abrir un eterno presente y un futuro sin memoria.

Mabel Moraña ${ }^{17}$ recuerda que debemos distinguir entre el olvido terapéutico y el silencio impuesto como manipulación de una conciencia colectiva, de la memoria cívica que es garantía democrática. En este horizonte se desvanece el basamento y legitimidad de la democracia.

La escritura representa para Matilde Herrera, desde su lugar de enunciación, una práctica social que busca una reparación simbólica construyendo un "lugar de memoria". ${ }^{18}$ Piensa el pasado en función del presente y sobre todo del futuro. Su libro humaniza a la víctima y así identifica al victimario, por lo tanto es una respuesta a la impunidad que ya en 1987 se había iniciado con la Ley de Punto Final sancionada un año antes.

José es la materialización de la praxis que vuelve posible la esperanza de construir el futuro a partir de la memoria del pasado; es una forma de resistencia a la política del olvido. En su clausura, el texto dice: "Sus verdugos no lograrán jamás que se cierren sobre tantas víctimas las nieblas del olvido (...) seguirás viviendo, José, también en estas líneas". (Página 433).

La lectura de este texto hoy puede resignificar la praxis vital de Matilde Herrera a la luz de diversos acontecimientos. Tal vez el de mayor impacto fue el testimonio del capitán de corbeta Adolfo Scilingo, registrado por Horacio 
Verbitsky en su libro El vuelo, y la autocrítica de las Fuerzas Armadas a través del jefe del Ejército, general Martín Balza. Estas revelaciones, sin embargo, mantienen vigente la impunidad, lo siniestro que entraña la justicia no aplicada. El consenso social, que no ha legitimado el olvido, ha vivido el silenciamiento como una derrota y desarrolla un escepticismo paralizante. El efecto sobre la producción cultural es un relato que impulsa a reescribir el pasado desde lo simbólico y lo ficcional. 
- Notas

1 ANGUITA, Eduardo y CAPARROS, Martín. La voluntad III. Una historia de la militancia revolucionaria en la Argentina. 1976 - 1978. Buenos Aires, Grupo Editorial Norma, 1998, páginas 19 - veinte.

2 En el prólogo a Nunca más.

3 NOLTE, Ernst. Después del comunismo. Buenos Aires, Ariel, 1996.

4 En su libro La sangre derramada. Ensayo sobre la violencia política. Buenos Aires, Ariel, 1998, página 121.

5 Publicado en $\mathrm{Ni}$ el flaco perdón de dios. Hijos de desaparecidos, una recopilación de Juan GELMAN y Mara LA MADRID. Planeta, 1997.

6 En su "Carta abierta a la Junta Militar", del 24 de marzo de 1977. (En El violento oficio de escribir, Buenos Aires, Planeta, 1995, página 4veinte).

${ }^{7}$ Categoría planteada por el grupo de investigación sobre narrativa posterior a 1983, que dirigía Julio SCHVARTZMAN en el Instituto de Literatura Hispanoamericana.

${ }^{8}$ En un testimonio titulado "Vientres" y publicado en Ni el flaco perdón de dios, opus cit. página 55.

9 En su ensayo "De falsas culpas y confesiones: avatares de la memoria en los testimonios carcelarios de la guerra sucia", publicado por BERGERO, Adriana y REATI, Fernando (Comp.) en Memoria colectiva y políticas de olvido, Beatriz Viterbo Editora, Rosario, 1997, página 225.

${ }^{10}$ Beatriz SARLO dice: "Es complicado vivir con la idea de que nos hemos equivocado. La excusa de que fuimos lo que debimos ser en cada momento parece más amable... " (Punto de Vista № 58, página 19).

11 Me refiero a Raúl BECEYRO en su artículo "Otra vez los fantasmas del pasado" (Punto de Vista N 58 , páginas veinte a 23).

12 TODOROV, Tzvetan. Frente al límite. México, Siglo XXI, 1993, página 239.

13 TODOROV, Tzvetan. Opus cit., página 2cuarenta.

14 Concepto de Walter MIGNOLO enunciado en su artículo "Los estudios subalternos ¿son posmodernos 0 poscoloniales?. La política y las sensibilidades de las ubicaciones geoculturales". (Revista Casa de las Américas, Vol. 37, No veinte4, 1996) 
${ }^{15}$ Marina PIANCA en su ensayo "La política de la deslocación (o retorno a la memoria del futuro)" (En BERGERO, Adriana y otro. Memoria colectiva y políticas del olvido. Beatriz Viterbo Editora, Rosario, 1998) desarrolló los tres tiempos vinculados con una manera de concebir la política del olvido: "Amnesia, tanto del pasado como del futuro en la deslocación".

${ }^{16}$ BERGERO, Adriana y otro. Opus cit., página 17.

17 Opus cit., página 33.

${ }^{18}$ En el sentido que Pierre NORA le otorga a esa expresión. 
Capítulo IV

Huellas del pasado en el mundo ficcional de El fin de la historia, de Liliana Heker 
En primer lugar es conveniente recordar que esta obra forma parte del corpus de la presente investigación porque representa una diferencia de grado de ficcionalización respecto de José, de Matilde Herrera, y Recuerdo de la muerte, de Miguel Bonasso, de modo que contribuye a la fundamentación de la hipótesis teórica inicial sobre el relato testimonial (ver Capítulo I).

El fin de la historia es una novela que desde lo ficcional intenta una evaluación del pasado focalizando la represión de la década del setenta. Mi lectura está motivada por dos cuestiones que han sido organizadoras del corpus. Por un lado, cómo se representa la década del setenta en el mundo creado por la novela y cuál es su proyección sobre el presente. Por otra parte, orienta la investigación la pregunta acerca del testimonio, su lugar en el texto y los sentidos que adquiere por sus relaciones interdiscursivas.

Mi análisis se inspira en un horizonte al que Paul Ricoeur llama "una trascendencia inmanente al texto". ${ }^{1}$ En efecto, se trata de una obra que se libera de su propio cierre para dirigirse al lector, y es justamente en la intersección entre el mundo del texto y el mundo del lector donde se consolida su significado. Dicho encuentro exige una teoría de la lectura en la medida en que ésta constituye una actividad que otorga a la literatura el poder de conocer, descubrir, evaluar y aun transformar el quehacer humano.

Estas consideraciones marcan una diferencia entre dos planos de lectura crítica. En el primero el interés estará puesto en su configuración; el segundo plano se localizará en la visión del mundo que dicha configuración proyecta.

El mundo del texto en El fin de la historia presenta una estructura narrativa cuyos elementos destacables son: la voz, el punto de vista y la organización del tiempo. No obstante, el análisis de estos aspectos inmanentes será un medio para que la obra hable y se dirija a su lector, por lo tanto sirve de soporte para verificar algunas hipótesis de lectura que enunciaré aquí provisoriamente:

La primera de ellas es que El fin de la historia es una novela que contiene en su propio programa una reflexión sobre la escritura, sobre el relato y consecuentemente sobre la ficción. 
La segunda hipótesis en torno de la que argumentaré es que puede caracterizarse como una novela temporal, en tanto el procedimiento narrativo más visible pone el acento en la relación entre los tiempos de narración y el narrado, cuyo efecto es la fragmentación del tiempo cronológico propio de la historia, pues subvierte la temporalidad impuesta por el historiador en la escritura e instituye la temporalidad propia del relato de ficción, lo que establece una continuidad entre pasado, presente y porvenir.

Una tercera hipótesis de lectura puede derivarse de la afirmación anterior: la configuración del tiempo en la novela demuestra que la narración puede aspirar a un modo alternativo de inteligibilidad del mundo, en tanto produce en el lector "una experiencia ficticia del tiempo", en términos de Paul Ricoeur ${ }^{2}$. Así, el lector salva el umbral entre configuración y refiguración del mundo descubriendo las marcas ideológicas conque se construye el pasado desde el presente y se anticipa el futuro.

La cuarta hipótesis es consecuencia de lo expresado anteriormente. El relato testimonial ingresa a la escritura de la novela y se lee en mayor grado de ficcionalización. Actúa como un sustrato del mundo textual que en su encuentro con el mundo del lector se resignifica, pues en este último opera un universo discursivo en el que participan la ficción y la información, pero también la realidad como experiencia de vida, la que trasciende a veces el lenguaje.

\section{I - Voces y perspectivas}

Un rasgo evidente de la novela es la complejidad de su configuración narrativa, que se produce por la presencia de diversos procedimientos.

Una de las técnicas destacables es la alternancia de voces, la del narrador básico, la de los personajes Diana, Leonora y Hertha Bechofen, y la de sujetos enunciativos que ingresan al texto mediante la citación de crónicas periodísticas. Sin embargo, existe una voz que en la cúspide de la pirámide organiza a las otras, en función de un proyecto de significación ideológica.

El narrador básico en tercera persona se presenta ya en el primer capítulo con mayor grado de conocimiento que los personajes e incluso esboza 
cierta complicidad con el lector mediante el uso de construcciones parentéticas. Así dice, por ejemplo:

"Y (aunque ninguna de las dos lo sabía), en el instante en que la mujer cetrina dejara sin vacilar la calle ... empezaría una vez más a desencaminarle el relato”. (Pág. 11)

La intervención del narrador básico abarca a ambos personajes, a Diana y a Leonora. Pero, ¿qué cuenta de ellas? El relato se vale de un procedimiento de escritura y con él crea el discurso de su personaje, Diana, quien a su vez introduce al actor de su propia "novela", Leonora, en el llamado "cuaderno de tapas amarillas". Esta ejecutoria hace de la novela una propuesta metaficcional: es narración de otra narración en un grado sucesivo de ficcionalización. El procedimiento de cajas narrativas, unas dentro de otras, utilizado por Joseph Conrad, acentúa la subjetividad de lo narrado; es imposible ser objetivo, parece decir la autora, como sugiere Conrad. Esto también se hace explícito en la figura del escritor "miope" que no ve la realidad sino formas difusas que permiten un imaginario. Es entonces cuando, como expresa el texto, "el disparate se mete en la historia”. El juego de ambos conceptos, Historiahistoria, restituye al interior de la narración un problema de reflexión teórica: la tensión entre historia-literatura, ficción-realidad, y abarca aún la cuestión de la verdad:

“... El disparate se mete en la historia, había anotado, aunque no en el cuaderno de hojas amarillas ... El disparate se mete en la historia. Nada más cierto. Se le metía en la Historia, perversamente impedía que afrontase lo puramente histórico pese a su decisión de que sólo lo histórico tenía un sentido ...” (Pág. 13)

La voz del narrador básico incorpora además otro recurso. El lector participa del relato en primera instancia por una forma apelativa en segunda persona, dice "de donde nadie va a echarte" y luego se suma a la voz narrativa mediante el plural: 
“iBasta! Decíamos que ningún conflicto entre a la peluquería”.

(Pág. 67)

Con esta forma coloquial se crea el marco explicativo del procedimiento de escritura de esta historia. La muerte invade lo cotidiano, el terror es totalitario, de modo que las peluquerías dejan de ser "sitios blindados" y la revista es el vehículo para incorporar la realidad, discursivizada en ese pequeño mundo de ficción. Es justamente la nota periodística la que impulsa a la acción de la escritora-protagonista: conocer, hacer, enfrentar la realidad para poder contar; la escritura no puede obviarla.

El lector se pregunta, entonces: ¿Cuál es la realidad que la novela, a través del proyecto creador de Diana, va descubriendo? Una palabra podría resumir la respuesta: "desaparecido". Su campo semántico asociado al terror, la tortura y la muerte pone en contacto los dos mundos, el de Diana y el de Leonora. Los dos relatos, el del narrador en tercera persona y el de Diana en primera persona se encontrarán allí. El lenguaje en su organización sintáctica, su puntuación que indica una continuidad de un pensamiento a otro, la participación de diferentes voces sin indicadores formales que alerten al lector, muestra el desconcierto, la imposibilidad de aprehender los alcances del término.

“...un aura de espanto alrededor de la palabra mágica ya que nada desaparece, Dianita, la gente no se esfuma en el aire como el genio de la lámpara, entonces los sacan de la realidad, mamá, los escamotean de nuestro mundo para tenerlos a su merced ... ". (Pág. 93)

En ocasiones el narrador básico adopta una posición equidistante respecto de los personajes y surge así una confrontación Diana-Leonora fundada sobre diferencias en torno a intelecto-cuerpo, palabra-acción, y aún ante la muerte. Dice, por ejemplo:

“... la que está a punto de doblar por Montes de Oca conoce muy bien puesto que ha visto la muerte de cerca. Ha planeado la muerte ... ha matado a un hombre. 
La que espera trata de desentenderse de la muerte ...”. (Pág.

28)

La voz en primera persona del plural de Diana como narradora del "cuaderno de tapas amarillas" ingresa al texto con un relato tipográficamente diferenciado, en el que es protagonista y testigo de los acontecimientos, y que remite a un pasado retrospectivo ("invierno de 1958") y también profético:

"E íbamos a vivir con el sobresalto -y el extraño sosiego- de haber decidido que el mundo no podía prescindir de nuestros actos”. (Pág. 18).

El tiempo es señalado también por las circunstancias históricas que el narrador enumera como si se tratara de titulares de un diario. Los hechos históricos, políticos, policiales y cotidianos se yuxtaponen como en la lectura de un periódico; este discurso apela a la memoria popular y así introduce la Historia en el discurso literario. El eje del relato de Diana es la vida de Leonora, su infancia, su adolescencia, siempre en relación con su militancia y su propia historia justificada por la amistad.

La Historia se presenta como un contexto determinante de la historia privada y viceversa:

"Así cantábamos y así éramos aquel invierno de mil novecientos cincuenta y ocho, cuando en nuestra tranquila Escuela Normal del barrio de Almagro irrumpió la Historia [...] Nuestra sería la Revolución Cubana y nuestra la Guerra de Vietnam [...] A los quince años bajo las glicinas...creíamos verificar para siempre palabras leídas con unción: la causa del pueblo es la causa justa, toda causa justa conduce a la victoria, nosotros tenemos un papel que cumplir en ese camino a la victoria”. (Págs. 17-18)

La alternancia de las voces se intensifica en el relato de la caída, la prisión y la tortura de Leonora. Mientras el relato de Diana exalta la vitalidad de Leonora, su adolescencia que se debate entre la pasión del amor y de la 
política, el narrador básico se demora en contar la tortura. La confrontación agudiza el horror y la deshumanización del personaje sin nombre, que es sólo cuerpo y grito, pero profundiza el sinsentido del dolor y la muerte cuando el origen de la militancia fue tan sólo una pasión adolescente o un impulso condicionado por la historia:

"Y arrebatada por sus palabras cree estar hablando también de Leonora y de toda su generación, los que...entramos a la edad de las preguntas cuando aún se oían ecos apagados de la bomba... y leíamos tempranamente $y$ apasionados El Manifiesto Comunista y teníamos de verdad la vida por delante y la revolución en nuestras manos y creíamos estar a las puertas de todo, y una noche sin previo aviso caímos como en un pozo sin fondo en este miedo". (Págs. 51-52)

Cuando la lectura pone en relación a los dos relatos encuentra una primera actitud de arrepentimiento en la protagonista. La soledad obliga a la prisionera a invocar a Dios y a rezar, aferrándose a lo que en su actitud revolucionaria había combatido:

"Y arrogantes y todopoderosas y libres como el viento exponíamos así, con esta devoción religiosa nuestra independencia de todo Dios, pero sobre todo del Dios burócrata ...”. (Pág. 63)

El narrador básico desplaza su punto de vista y focaliza los hechos y los espacios desde la perspectiva de la prisionera, "a través" o "debajo" de la "capucha" (embozo característico de las cárceles clandestinas) que marca el límite entre el afuera-adentro, luz-oscuridad y entre los tiempos antes-después de la caída.

"Fue una alteración insignificante y breve; sin embargo, debajo de la capucha que la ciega, ha puesto en marcha un mecanismo que pareciera prescripto de tenue urdimbre de luz que ahora otra vez se filtra a través de la capucha le confirma que es el sol lo que pasajeramente había desaparecido... O sea 
que ya sabe a dónde la llevan: ha caído en manos de la Marina”. (Pág. 38)

Pero tal vez la presencia más fuerte del punto de vista del personaje se encuentra en el capítulo 7, en el que se describe el espacio de la tortura. La voz narrativa utiliza una forma impersonal, lo que en principio imprime al discurso un carácter informativo; sin embargo, la expresión que clausura la descripción permite reconocer la voz de Leonora. Dice:

"se puede vislumbrar una estrella. Y eso alcanza para que sea feliz, siempre y cuando se disponga claro de una buena dosis de alegría interior". (Pág. 113)

Sin duda, su identidad se manifiesta en el fluir del pensamiento citado en estilo directo y en el que se destaca su pertenencia a un movimiento, a una organización. Dice en primera persona del plural:

“... un día supimos hacer nuestra la causa de esas mujeres y de esos hombres), nosotros, el heroísmo y la lealtad y la ética y el sentido de justicia lo empezamos a aprender entre aventuras, en esos libros...”. (Pág. 112)

Esta reflexión pone en contacto al lector con la intimidad del personaje y lo hace partícipe de su sentimiento nostálgico.

"Fueron -ellos mismos- nuestra aventura y nuestro alimento". (Pág. 112)

El último capítulo propone al lector una actividad que induce a una reescritura de la novela. Narrado en primera persona del singular, la primera cuestión a resolver es quién narra. Leyéndolo como respuesta a la pregunta que cierra la penúltima parte: “¿Y qué le vas a decir?” (pág. 234), “La verdad ... “ (pág. 235), se descubre una voz narrativa, la de Hertha Bechofen, cuya presencia a lo largo del texto adquiere ahora sentido.

Ya el narrador básico había citado en estilo directo la voz de la "mujer mayor" que explica así su razón de ser como personaje de esta novela: 
"Sólo quiero poseer su historia [...] Develar el significado de estos actos mínimos, aparentemente ahistóricos, que sin embargo interceptan la Historia y la desvian hacia un curso imprevisible. Confieso que a las puertas de mis setenta años eso es lo único que me interesa". (Págs. 76-77)

Su encuentro con Diana conlleva un anticipo: "puede interferir en los hechos y volverse usted misma personaje" (pág. 96), y también una sentencia: "que no tengan ganas de discutir, eso es lo malo. Otra manera muy refinada, muy peligrosa de matarlos" (pág. 96). Ambas son claras expresiones de su función en el mundo del texto: desde su perspectiva se cuenta el procedimiento de escritura de la novela. Diana-escritora es la protagonista de este relato.

En el taller de Garita, Hertha Bechofen prepara la comida y cuenta historias. En ese espacio confluyen todos los tiempos. El pasado que ingresa en tono nostálgico en la voz de Garita: "Yo no armé todo esto para que los sobrevivientes vengan a hablarme de lo que afuera está prohibido. Lo armé porque ya no existe el instituto donde daba clases, y de la Universidad me fui solo porque me daba asco" (pág. 133), y que ilumina desde allí el presente "casi histórico, predicando en la catacumba" (pág. 133).

El taller es un pequeño mundo ficcional en el universo de ficción creado por el texto. Desde ese mundo se objetiviza al otro, ambos son ficcionales, la realidad se diluye en el mundo del texto; sin embargo no puede ausentarse del mundo del lector.

En la cocina de Hertha Bechofen se cuenta otra historia, enmarcada, que representa una inversión de la historia principal de Leonora y marca la diferencia héroe-antihéroe. La protagonista vive una historia de amor, pero elige ser fiel a los ideales de la revolución. La sentencia final contiene una evaluación para Leonora: "Lo único ético -el tono de ella es terminante- era elegir la causa trascendente, en este caso la causa de todo un pueblo" (pág. 163). De este modo, el futuro plasmado en el último capítulo se anticipa en el espacio del taller.

La relación entre Hertha Bechofen y Diana es pedagógica y el taller es un pequeño laboratorio. Diana dice: "Vine porque quería encontrar el camino 
para contar una historia muy precisa" (pág. veinte5). La voz de Hertha Bechofen define a la Historia y le da sentido a la escritura:

“... la Historia no deja resquicios, siempre es completa y maciza y avasallante, es uno mismo quien debe abrir la grieta $y$ echar una mirada sobre el pequeño y amable mundo." (Pág. 103)

“Eso es literatura, ... y la literatura sí, si una se empeña -la mira fijamente- si una quiere tomarse el trabajo termina pareciéndose bastante a lo que una quiere”. (Pág. 234)

En ese espacio y a través de este personaje, se muestra el carácter metanarrativo del texto y se reconoce a la novela como literatura que habla de la Literatura, y aún de sus diferencias con la Historia.

Hertha Bechofen tiene otra función en el texto, que es contar el final de Leonora. En ese relato el lector encuentra el signo vinculante de ambas trayectorias de vida, la de la intelectual y la de la militante, instrumentos de evaluación de otra historia: la de los movimientos revolucionarios, las causas y los resultados de la revolución. En ambos casos el saldo es el fracaso, la imposibilidad de la escritura y la desilusión de la revolución social en el sistema capitalista. La evaluación del pasado en clave de presente también analiza las razones: los ideales revolucionarios fueron una pasión de juventud y un pathos histórico.

En síntesis, en este apartado he analizado la presencia de distintas voces narrativas y puntos de vista, que responden, en un plano fraseológico, a un narrador básico en tercera persona y a narraciones ficticias en primera persona del singular y del plural. Tal es el caso de personajes como Diana, Hertha Bechofen y Leonora.

Estos aspectos toman cuerpo especialmente en el plano ideológico, en tanto regulan la visión del mundo que presenta la obra. Como dije al principio, se registra un único proyecto ideológico que gobierna la organización de esta narración: la evaluación del pasado en clave de presente que señala el fin de la historia, de la revolución. 


\section{II - Los tiempos del relato}

Otro rasgo propio de la compleja configuración narrativa de la novela es la organización de los tiempos del verbo y su sentido en el mundo ficcional del texto. Es posible distinguir un tiempo de narrar y un tiempo narrado, y la experiencia de ficción del tiempo. La escritura ha puesto el acento en un fluir permanente entre ellos, imitando la forma en que opera la memoria, de manera que el lector se ve obligado a refigurar el relato apoyándose en algunos indicadores temporales y así reescribir la historia.

El tiempo de la narración se registra en tres instancias, a saber:

1976: "Miro a mi alrededor en esta noche especialmente negra de mil novecientos setenta y seis en que sólo alcanzo a ver muerte y carne desbastada y sin embargo sigo tecleando con empecinamiento estas palabras, tal vez porque no puedo arrancarme del corazón la esperanza”. (Págs. 18-19)

1977: "Porque mi horror consistía en que estaba viva... y la intolerable culpa de estar viva. Ése era el horror que yo tenía para contar: la alegría, y el miedo, y la culpa, y la furia, y la impotencia y el asco, todo junto conviviendo dentro de mí en ese despiadado invierno del setenta $y$ siete”. (Pág. 206)

1979: "Ha regresado después de casi dos años [...]

"- Lo primero que descubrí es que ya nunca voy a poder escribir esa novela..." (Pág. 230).

Estos tres datos cronológicos señalan el proceso de escritura de "la novela de Diana Glass". En 1976 evoca la vida de la protagonista, su niñez, su adolescencia, y paralelamente el narrador básico cuenta la trayectoria de Leonora hacia la caída. En 1977 se explicita la intención del proyecto creador de Diana como intelectual y como respuesta a la militancia revolucionaria de Leonora, representativa de una generación. Mientras tanto, el relato del 
narrador en tercera persona se centra en la prisión y la tortura. En 1979 se descubre otra verdad que funda la presencia del antihéroe, por lo que se explicita el fracaso de la novela de Diana para dar lugar a otra historia, la de El fin de la historia como totalidad.

Este registro de los tiempos de la narración confirma el carácter metanarrativo y metaficcional de la novela. Desde esa perspectiva el texto habla de la escritura, de la lectura y de la ficción y entonces el lector se encuentra ante estas propuestas:

* La escritura discursiviza la memoria que recupera el recuerdo generado por la lectura de otros textos y de las fotos. Por lo tanto, la narración surge de la lectura de la realidad discursivizada en textos periodísticos y de la experiencia de vida.

* La ficción tiene un universo primario con acento en la realidad, pero la incursión en pequeñas historias como verdades alternativas y la intencionalidad del proyecto creador marcan la construcción de la historia y se crea un mundo posible. En este marco, la lectura implica la reescritura del texto para resignificarlo.

La armazón narrativa está asegurada por los relatos escritos por Diana Glass, cuya función es contar los hechos en un pasado retrospectivo, anterior al tiempo de narración. Estos acontecimientos del tiempo narrado señalan el crecimiento de las protagonistas, Diana-intelectual y Leonora-militante desde la niñez (1957-58), la adolescencia (1971-1973), la adultez (1976-1977) y la madurez (1979).

Sin duda, la técnica narrativa más eficaz por el efecto de ficción es la utilización del presente del verbo "decir" para citar en estilo indirecto la voz de Leonora dando testimonio sobre su experiencia como "desaparecida". Esta estrategia de uso del verbo actualiza la narración pretérita en el presente de lectura.

No obstante, la experiencia ficcional del tiempo está inscripta por el narrador en esa alternancia que supera todo intento cronológico, propio del discurso histórico, que obliga al lector a reescribir el relato y posibilita múltiples lecturas. 
La temporalidad fragmentaria que imita la forma de operar de la memoria privilegia una organización de la experiencia centrada en los hechos. El eje de la novela es el relato de la prisión y la tortura, en el que se suspenden las nociones tradicionales de tiempo y espacio, al igual que los valores habituales de la moral. La tortura marca un antes y un después para la historia de las dos protagonistas, para la escritura y para la militancia. Leonora se fragmenta en héroe-antihéroe y la novela de Diana se disuelve en la imposibilidad de la escritura.

En la construcción de la experiencia ficcional del tiempo cumple un papel muy importante el relato testimonial, que actúa como sustrato de la narración novelesca, aspecto que será objeto de análisis en el próximo apartado.

\section{III - Testimonio y producción de sentido}

La cuestión central que enuncié como orientadora de mi investigación es acerca del relato testimonial. En principio me referiré a su localización textual, para luego analizar su función en el plano ideológico y su rol en la producción de sentido.

Mi hipótesis es que la novela produce una reescritura de los relatos testimoniales de reaparecidos ${ }^{3}$. Como consecuencia de esta afirmación se derivan otras consideraciones que enunciaré a continuación.

El relato testimonial se encuentra en el sustrato de la narración, en el mundo del texto, pero también forma parte del mundo del lector, en tanto es un discurso que contribuye a la constitución de las representaciones públicas de la represión de 1976. Es así como en el mundo del texto se presenta de dos maneras diferentes:

1 - Como testimonio de un reaparecido transcripto en estilo indirecto por un interlocutor ausente-presente (cap. 13 - apartado final).

2 - Como relato testimonial de prisión constituye la base de la narración de la "desaparición" del personaje (caps. 2 al 10).

\section{- El relato testimonial en estilo indirecto}


En el capítulo trece se produce un cambio en el estilo narrativo que amalgama relato y diálogo a través del discurso indirecto. Éste se presenta como una forma de enumeración informativa que reproduce enunciados en tercera persona. Así se inicia el capítulo:

"Que en la embajada argentina creían que eran sociólogos dice...". (Pág. 213)

El antecedente de esta situación enunciativa se encuentra en el capítulo diez, cuando el narrador-interlocutor presenta la relación amorosa entre la prisionera y el Escualo:

"Que fue curioso escucharlo decir eso, me dirá la prisionera ...". (Pág. 168)

El narrador de la novela logra un mayor efecto ficcional con una estrategia recurrente: creando en el lector la necesidad de resolver un acertijo para armar la historia total. En este caso, la pregunta es acerca de este interlocutor: ¿De quién se trata? La novela habla de su clausura y obliga a una lectura que vuelve al principio. Así es como en el último capítulo se devela la identidad, se trata de Hertha Bechofen, a quien me he referido anteriormente cuando analicé las voces narrativas. (Ver Capítulo I.1)

Es necesario precisar ahora cuál es la posición del interlocutor. En principio, es posible observar que el locutor se ubica tan sólo como traductor, se coloca en el lugar del que refiere, y de este modo le dice al lector que reproduce lo que el personaje dice, pero no se hace responsable de ese discurso. Esta posición de quien refiere resuena en el texto y apunta tanto al contenido de la enunciación como a su locutora, a los que expone para ser sometidos al juicio del lector.

Otro aspecto a considerar es que el yo-interlocutor que reproduce el testimonio es un sujeto presente-ausente, pues el lector debe buscar marcas en el texto para identificarlo, como por ejemplo la presencia de la niña, que vincula este capítulo con el último y revela que pertenecen a la misma situación comunicativa. 
Luego, la construcción sintáctica pone el acento en la voz testimonial, por lo que cada sintagma se inicia siempre con el subordinante "que". El personaje aparece retratado en el aquí y ahora de su subjetividad como yo de origen del discurso.

En esta construcción sintáctica el verbo "decir" no siempre es introductorio sino que es un verbo de situación; como consecuencia se diluye la diferencia entre el narrar y lo narrado. Por otra parte, el tiempo presente "dice" produce un fuerte efecto de ficción mediante dos recursos: trae el pasado al presente de la lectura y amalgama la conversación y el relato.

En este universo ficcional el lector se enfrenta con datos que integran su propio mundo y pertenecen a la realidad histórica: las listas de desaparecidos, las Madres, las Abuelas, "los cadáveres flotando en el río". De modo que este gesto formal de imparcialidad que impera en el mundo del texto encubre sin embargo una evaluación de los hechos y de la conducta de la protagonista que tiene su registro en el discurso.

Algunas estrategias del sujeto interlocutor dan cuenta de ello:

- La reiteración de la identidad Escualo-Pedro es una manera de recordarle al lector que se trata del militar torturador y enfatiza la traición de la protagonista.

"Que no le cree del todo, no porque piense que El Escualo mienta - Pedro no miente, dice ...”. (Pág. 216)

- Las preguntas encubiertas en las respuestas señalan otras alternativas a la conducta de Leonora, la resistencia y no la traición.

"Que no: que nunca se le cruzó la idea de escapar.

Escapar de qué, me pregunta y se encoge de hombros".

(Pág. 214)

En cuanto al sujeto testimoniante reproduce el discurso de los represores y argumenta justificando sus acciones con diferentes estrategias:

- Refutaciones a las acusaciones implícitas en las preguntas del interlocutor que representan a la opinión pública:

"No es que yo apruebe la tortura...dice, pero a veces hay 
que dejar de lado los sentimentalismos ...”. (Pág. 214)

"Que mataban inocentes, eso era cierto, pero qué otra posibilidad cabía no habiendo juicios". (Pág. 214)

- Exaltación de los valores de los represores en el cumplimiento del deber, en la organización y estrategia militar, y de su carencia de un proyecto político.

"Que piense en el Almirante: organiza lo de la Escuela, forma un equipo de colaboradores de lujo, y después ni sabe qué hacer con eso". (Pág. 219)

Sin embargo, el lector puede confrontar esta opinión con la realidad histórica y sabe que hubo un proyecto político que suspendió la política como derecho del ciudadano.

- Enunciados generales de aparente comprensión del otro que encubren la traición.

"A veces hace falta ponerse en el lugar de los otros, dice,

y que nadie tiene la verdad absoluta, solamente Dios".

(Pág. 214)

- Definición de la militancia, desprovista de ideales, de una causa, como una condición natural y genética que "se lleva en la sangre".

Estos fundamentos conducen a la despersonalización de las acciones represoras, que surgen por necesidad y por obligaciones a cumplir. Los militares son responsables pero no culpables, pues no existe una decisión o proyecto político.

Sin embargo, estos argumentos se neutralizan pues el mismo texto le brinda al lector la posibilidad de confrontar un episodio como la muerte de Fernando con el relato que hace la protagonista y elaborar su propio juicio.

Al respecto dice Leonora: 
"Que por supuesto Violeta lo quería al Escualo ... Que no; que de hecho no fue él quién lo mató a Fernando: en un operativo cada uno es un engranaje ...." (Pág. 218)

Pero el relato del narrador ya había presentado la escena:

“- Papá -dijo Violeta.

“- Disparen -dijo el Escualo”. (Pág. 153)

La justificación de los represores representa también una forma de justificar su colaboración. El último capítulo completa esta caracterización de la protagonista mostrando su cambio, su traición ya no sólo a un movimiento sino a sus ideales de vida. El juicio del interlocutor es explícito: desconoce su capacidad de amar, la autenticidad de su discurso y de la pasión.

"Tiene mucha fuerza. Iba a decir pasión pero no es más que el simulacro de la pasión...Usa mucho el verbo amar...Me habló... con el mismo arrebato con que -imagino- hablaba en las reuniones del Partido Comunista ...". (Págs. 235-236)

Ambos episodios tienen varios efectos de lectura: resignifican la trayectoria de ambas protagonistas, revelan la transformación de Leonora en antihéroe y explican la imposibilidad de la escritura de la novela de Diana. De esta manera, la novela como totalidad muestra la experiencia de una generación, analizando el pasado desde el presente de escritura-lectura.

\section{- La reescritura de los relatos testimoniales de reaparecidos}

Los episodios que desarrollan lo que hemos denominado "la caída" focalizan una acción, la tortura, y abarcan los capítulos 2 al 10 .

Se trata de la reescritura de una experiencia de prisión que ingresa al texto de ficción con temas recurrentes propios de los relatos testimoniales de reaparecidos, que he abordado en los capítulos precedentes pero que entiendo merecen atención también en este texto. Mencionaré algunos de ellos, tales como: 
- La suspensión de las nociones de tiempo y espacio propias de la civilización.

- El espacio como prolongación del cuerpo.

- La presencia de la dimensión del cuerpo y sus necesidades.

- La descripción de técnicas de tortura y del proceso de interrogación.

- La desintegración del mundo de la víctima.

- La deshumanización del prisionero.

- La homologación de la tortura al poder.

Un aspecto se distingue de otros relatos: no se anula la conversación sino que el lenguaje sirve como medio para la confrontación de los poderes de ambas fuerzas, es decir el saber de los montoneros y la disciplina y organización de los militares.

"Todavía les quedan muchas cosas por aprender de nosotros, Capitán -le dice". (Pág. 61)

“-¿Aprendió la lección de la montonera, Escualo? Eso es lo que hace falta acá: gente inteligente y con pelotas". (Pág. 72)

Los relatos testimoniales de reaparecidos han sido releídos desde una perspectiva moral. Como consecuencia, la protagonista de la novela en su razonamiento plantea una dicotomía entre delatar y confesar. Con estos parámetros la prisionera entrega la carta como prueba material de su confesión y justifica su acción:

"Esto no es delatar...en todo caso es delatarme a mí misma ...Qué más da que ahora también...mi desconfianza acerca de los métodos que está usando la organización". (Págs. 59-60)

La confesión se transforma además en una situación que pone en juego el contraste entre dos tipos de valores: los valores vitales y los valores 
morales ${ }^{4}$. En la expresión de uno de los personajes, el Chango Hernández, se da cuenta de ellas:

“...si uno deja de lado ciertos principios tal vez encuentre maneras de sobrevivir en trabajos técnicos...cosas que uno sabe hacer y que a ellas les sirven". (Pág. 61)

Su confesión recibe un juicio de parte del lector, quien desde su aquí y ahora conoce las consecuencias históricas y sabe el para qué "a ellos les sirven" esos trabajos. Esta conducta de la prisionera tiene además otra contestación: la defensa que esgrime en el capítulo trece y que he desarrollado anteriormente.

Por otra parte, siempre en el plano ideológico, la relectura y reescritura de los testimonios de reaparecidos que se encuentra en la novela de Liliana Heker contiene un profundo enjuiciamiento en el que se perfilan claramente las características del antihéroe, y por oposición natural, las que se esperan del héroe.

Las acciones de la protagonista no obedecen a los valores morales en tanto no respeta principios que exigen lealtad, el cuidado del otro y su derecho a la vida. Su conducta puede verse como un proceso de cambio cuyo primer paso es la confesión, que involucra exclusivamente a su persona, es individual, pero que pronto se transforma en delación a través del trabajo de escritura, y en este caso involucra a la Organización, a lo colectivo. La colaboración con los represores, a través del asesoramiento para manejar por ejemplo a las Madres de Plaza de Mayo como organismo de Derechos Humanos, la convierten en traición. Finalmente, hay una identificación con el proyecto de los militares que puede verificarse en la defensa de sus valores y de su causa.

Sin embargo, el lector no se ve sorprendido pues el relato presenta algunos antecedentes que hacen coherente la conducta de Leonora, ya que relativizan su compromiso con el movimiento montoneros. Mencionaré tres ejemplos que ilustran esta afirmación:

* Se desmitifica su ingreso en el Movimiento y su participación revolucionaria, vinculándolos sólo con una conducta propia del apasionamiento adolescente e impulsada por el condicionamiento histórico. 
* El origen burgués e intelectual de los militantes, que sin embargo no vivenciaron la situación de aquellos por quienes se haría la revolución social.

* La militancia tiene un origen genético, "se lleva en la sangre", por eso las acciones se presentan tan sólo como teológicas y están desprovistas de su carácter intersubjetivo. No responden a los ideales de una causa.

Esta protagonista se distancia del modelo heroico. La escritora de la ficción Diana Glass dice:

"Se trata de lo que quería contar...Por eso necesitaba una heroína... y un día me topé cara a cara con la protagonista...". (Pág. 230)

Es en este momento cuando el lector se pregunta: ¿Qué se entiende por el heroísmo?

Para responder recordaré la tesis de Tzvetan Todorov, quien sostiene que la moral es constitutiva de la vida y que por lo tanto no se suspende ni aún en situaciones límites, o en el umbral del sufrimiento ${ }^{5}$. Por el contrario, bajo circunstancias extremas los actos humanos responden a lo que denomina "virtudes heroicas" o "virtudes cotidianas", ambas como actos de libertad y voluntad.

Los relatos testimoniales de reaparecidos las descubren, aunque prevalece en ellos un modelo de héroe que proviene de representaciones públicas y aún de la tradición occidental ${ }^{6}$. La cualidad más apreciada de la vida del héroe es la fidelidad a un ideal; es en este sentido lo contrario que el traidor, pues él no traiciona jamás, cualesquiera sean las circunstancias. Está pues, listo para sacrificar su vida si sirve para cumplir con un objetivo. El mundo de los héroes es unidimensional y sólo comporta dos términos: amigoenemigo, valor-cobardía, héroe-traidor.

En este marco, la relectura que produce la novela muestra sin embargo un héroe antes de la tortura y un antihéroe después. Aún cuando son los héroes los que mejor se prestan al relato, el proyecto ideológico de la novela se centra en las actitudes no heroicas ¿Cuál es la intención, pues, de este 
proyecto creador? El juicio del narrador cae seriamente sobre la protagonista, y con ella sobre el movimiento revolucionario, pero no puedo dejar de señalar que está acompañado por una caracterización del totalitarismo y sus efectos sobre la conducta del individuo cuyos detalles enunciaré a continuación:

* El enemigo es todo aquel diferente; se encuentra en el interior del país, y debe morir. Contra él se justifica una guerra de exterminio.

“Usted, pienso a veces, estaba equivocada, eso sí, pero todavía tiene ... No sé, usted es una persona. Como nosotros”. (Pág. 85)

"Yo, al menos, aspiro a un mundo en el que Garita tenga cabida. Molesto, homosexual, corrosivo ... Por algo así se lo llevaron ... no era un héroe, pero ésta no es una historia de héroes, hija, es una historia de asesinos y asesinados. Y también es una historia de sobrevivientes”. (Págs. 233-

* El Estado controla todo, aún el pensamiento de las personas y sus costumbres.

“ - ...Acá también la pasión hervía en los cafés. Por eso

me digo: debe ser difícil ser joven en un mundo de cafés.

- Ya le dije que no es lo peor que nos pasa”. (Pág. 96)

* El Estado y el deber detentan la medida del bien y del mal. Esto alivia la responsabilidad de quienes cometen atrocidades como la tortura, pues el Estado los obliga a tener una nueva moral en la que el fin justifica los medios. La causa de los crímenes no está por lo tanto en el individuo, pues éste forma parte de una red totalitaria, sino en el régimen político.

Aquí es conveniente recordar que nadie queda exonerado de su responsabilidad moral, sino que se lo excluye de la culpabilidad legal. Aunque se encuentre en situaciones extremas, el hombre no está enteramente privado de su posibilidad de elegir, por eso si lo que hace es malo, el ser también está alcanzado por el mal y no puede escapar a la responsabilidad moral. En 
palabras de Todorov: "No se puede rehacer el pasado pero hay que recordar en el presente cuál sería el precio de una guerra, y se puede anunciar para el futuro que incluso los crímenes legales serán castigados". ${ }^{7}$

Ahora bien, retomando la tesis de Todorov acerca de la existencia de dos tipos de virtudes, heroicas y cotidianas en la conducta humana, y en tanto ha quedado demostrado que la protagonista no posee valores heroicos sino todo lo contrario, queda aún una cuestión pendiente: el análisis de los actos de la protagonista a la luz de las virtudes cotidianas.

Según Todorov, la dignidad moral aparece como la primera de estas virtudes y sus notas características son el ejercicio de la voluntad y la expresión de la libertad aún bajo extrema presión; la coherencia entre el interior y el exterior de la persona, entre las decisiones y las acciones, lo que es sinónimo de respeto a sí mismo; el reconocimiento de los otros que identifique acciones dignas; el trabajo bien hecho sin perder de vista el fin de la tarea.

Con estos parámetros orientadores realizaré el análisis de la conducta de la protagonista, Leonora.

El primer aspecto a considerar es que Leonora pudo ejercer su libertad. Las opciones que se le presentaron son múltiples y están representadas por el accionar de otros personajes: el Chango Hernández, un colaborador con trabajos; la pequeña Malisa, delatora, y Fernando Kosac, que muere sosteniendo sus ideales hasta el fin.

Una segunda nota a analizar es la falta de coherencia entre la decisión y la acción. Su decisión no es delatar; sin embargo escribe el informe completo revelando todos los mecanismos de trabajo de la Organización.

Un tercer elemento a contemplar es la importancia que la prisionera le da a su trabajo. Éste representa una forma de mantener su dignidad individual, pero ha perdido de vista la finalidad, por lo tanto también representa una pérdida de la dignidad moral. Y además, la protagonista no obtiene consenso entre sus compañeros, que no le reconocen virtudes sino que le reprochan su traición: el Chango Hernández, el Tordo, la joven que muere en la tortura.

En resumen, la novela produce una reescritura de los relatos de reaparecidos ${ }^{8}$ en su universo de ficción para destacar los actos no heroicos de 
los militantes revolucionarios, pero también para demostrar que en ellos no hubo dignidad moral.

\section{IV - Mundo ficcional y representación del pasado}

En la novela se establece una estructura doble en la que se yuxtaponen dos relatos: el que efectúa en tercera persona el narrador básico y el que se establece en primera persona por parte de un narrador ficticio, Diana Glass. Como consecuencia, la lectura es una operación que reescribe la novela como totalidad poniéndolos en diálogo, y así describe una relación recíproca entre ambos relatos que abarca los planos funcional, actancial e ideológico.

Respecto del plano funcional cabe señalar la importancia del tiempo verbal. El relato en tercera persona indica un tiempo de narración que es el presente, cronológicamente marcado entre 1973-1979, pero que para la experiencia de ficción del tiempo del lector está fragmentado en un antesdespués de la tortura. El narrador básico cuenta por un lado una acción esencial: el proceso de escritura de la historia, y por otro el trayecto de la protagonista hacia el centro del relato, es decir la caída, la tortura y sus consecuencias.

Mientras que el relato en primera persona representa el pasado del personaje, con un sentido retrospectivo, y las acciones básicas pueden enunciarse como el proceso de formación de una militante revolucionaria y su modus operandi junto al de una intelectual-escritora, el proceso de la historia argentina es el contexto determinante de la historia de vida y viceversa.

El punto de contacto entre ambos relatos se encuentra en el plano actancial representado por Diana-Leonora, personajes en diferentes niveles de ficcionalización: el de Diana es creado por el narrador básico y su función es narrar como sujeto enunciativo ficticio la historia de Leonora, en la cual ella misma es protagonista. El narrador del relato marco aparece como garante de la historia que lee en los escritos de Diana.

Este relato en primera persona es una vuelta atrás, desde un presente fijo, a su vida pasada. Al modo de las memorias, el sujeto enunciativo realiza excursiones al pasado que constituyen acontecimientos del recuerdo 
interpolados en la narración marco. Como en una autobiografía en primera persona del plural, el narrador mira esas etapas y los otros personajes aparecen objetivados desde la perspectiva de un testigo y protagonista de los hechos. Este rol de narrador le da credibilidad al relato, cuyo centro de interés es la figura de Leonora y su historia como militante. Al mirar su vida mira también un mundo histórico y geográfico. Esta narración se presenta tipográficamente diferenciada e irrumpe en el relato con tres estrategias: como relato sin antecedente o nexo gramatical alguno, como cita de la escritura de Diana presentada por el narrador básico y como recuerdo a partir de una imagen o una palabra generadora.

Una crítica atenta a la pintura de los caracteres puede observar que esta inmersión en el pasado contribuye a reconstruir su forma implícita en el estado presente. El ensamblaje del presente narrado con el pasado recordado les confiere una identidad en la que operan las representaciones públicas acerca de las conductas en una dimensión ética.

La actividad de la lectura encuentra entonces que el relato del pasado en primera persona del plural ilumina la narración en tercera persona, en tanto proporciona información biográfica sobre los personajes que sirve como referencia para explicar la conducta del presente. Recordemos por ejemplo a personajes como Celina Blosh, antecedente de la posterior conducta de Leonora; "mi primo el Capitán, arma de salvación"; el episodio de La Tortosa, que destaca la necesidad de Leonora de ser protagonista y siempre admirada, y Fernando Kosac, paradigma de la figura revolucionaria que actúa como espejo invertido de Leonora.

Pero también la lectura descubre que ambos relatos conforman un único proyecto ideológico y que mediante recursos narrativos como la ironía, la parodia y la metáfora enfatizan algunos tópicos.

La parodia es un recurso que desde el humor permite mostrar el totalitarismo y sus efectos sobre la sociedad: la anulación del sujeto, su objetivación mediante el terror implantado en la cotidianidad y lo absurdo de sus procedimientos. Ejemplo de ellos es el encuentro con "la Galerita".

Frente a este universo el lector se pregunta: si, como afirma Todorov, la conducta no heroica se presta mal para los relatos, por qué y para qué esta 
novela cuenta la historia de un antihéroe o de un espíritu pragmático que ha logrado acomodarse a las estrecheces de la realidad.

El texto, en su "trascendencia inmanente", contiene una respuesta posible. Realiza una relectura de los relatos de reaparecidos y la historia se reescribe en el universo ficcional de la novela, pero para desmitificar la militancia revolucionaria de una generación en aquellos valores e ideales que otros discursos sostuvieron. En sus relaciones interdiscursivas, la novela como totalidad puede leerse como un gesto opuesto al de las Madres de Plaza de Mayo, pues representa una inversión de sentidos en la evaluación de las historias privadas y su relación con la historia pública de nuestro país.

En tanto, la metáfora que implica la narración en primera persona encuentra su significado en el relato marco y representa la decepción, la imposibilidad de la escritura, porque el héroe se ha transformado en un antihéroe.

"Una mañana resplandeciente de sol de la primavera de mis catorce años, un árbol cayó sobre mi cabeza”. (Pág. 37)

“...estaba hecha para beberse la vida hasta el fondo de la copa”. (Pág. 11)

Por su parte, la ironía prevalece, por ejemplo, en la evaluación del movimiento revolucionario, de sus militantes, destaca su origen burgués e intelectual. Podría citar numerosos ejemplos, pero entiendo que la ironía constituye un procedimiento estructurante en el último capítulo, donde el texto revela el proyecto ideológico imperante: la desmitificación de la militancia por ideales, lo absurdo de la revolución sin héroes, la falta de dignidad moral de algunos reaparecidos, la responsabilidad moral de individuos que implantaron el totalitarismo.

Esta evaluación contiene además una reflexión metanarrativa acerca de la relación entre la historia pública, aquella que opera en el imaginario social, la que el periodismo va creando, y la historia privada, interior, individual, cotidiana, que permite otra lectura de la realidad. $Y$ también una reflexión metaficcional acerca de las potencialidades de la literatura como discurso 
ficcional para crear un mundo que "termina pareciéndose bastante a lo que una quiere”. (Pág. 234) 


\section{* Notas}

${ }^{1}$ Paul Ricoeur en su obra Tiempo y narración I/ define este concepto: "Así es como la obra literaria, librándose de su propio cierre, se relaciona con ... se dirige hacia; en una palabra: es respecto de ... Más acá de la recepción del texto por el lector y de la intersección entre esta experiencia de ficción y la experiencia viva del lector, el mundo de la obra constituye lo que llamaré una trascendencia inmanente al texto". (Pág. 534).

2 En el capítulo 4, Ricoeur ejemplifica este concepto en el análisis de obras concretas. Afirma que "esta experiencia de ficción proviene de otra dimensión de la obra literaria distinta de la que consideramos aquí: su poder de proyectar un mundo ..." (Opus cit., pág. 494).

3 Se denominan "reaparecidos" a aquellas personas que estuvieron "desaparecidas", "chupadas" o más técnicamente "detenidas-desaparecidas" durante la dictadura militar, y luego fueron liberadas.

${ }^{4}$ Ambos conceptos son desarrollados por Tzvetan Todorov en su obra Frente al límite. México, Siglo XXI, 1993, pág. 46.

${ }^{5}$ Esta noción de umbral de sufrimiento pertenece a Tzvetan Todorov, opus cit., págs. $44-45$.

${ }^{6}$ Para el desarrollo exhaustivo de este aspecto es conveniente consultar el capítulo "Heroísmo y Santidad" de T. Todorov, opus cit., pág. 53.

${ }^{7}$ Todorov, T. opus cit., pág. 146

${ }^{8}$ Estos relatos se encuentran en Nunca más y en La voluntad, ya citadas. En esta última obra el testimonio de Graciela Daleo tiene notable interconexión con episodios narrados en El fin de la historia. 
Capítulo V

\section{Memoria y ficción \\ en la Argentina de fin de siglo}


Es mi propósito en este capítulo recuperar los conceptos que demuestran la consistencia de la hipótesis que ha orientado esta investigación, surgidos del análisis del corpus.

Entiendo pertinente concluir que el relato testimonial forma parte de un campo de discursos sociales, por lo que su comprensión implica ponerlo en diálogo con otros discursos donde el sentido se despliega y se construye en la relación intersubjetiva. Si consideramos que la narrativa histórica y ficcional tienen igual categoría, puesto que en tanto discursos simbólicos no se oponen sino que se complementan, podemos sostener la existencia de un campo de ficción en el que los relatos que constituyen su entramado mantienen entre sí una diferencia de grado. El efecto de ficción sobre la realidad es discursivo, se da sobre los universos simbólicos y consecuentemente modifica el horizonte de la cultura.

Estas ideas se apoyan sobre la lectura del sistema literario de la Argentina de fin de siglo, operación que me permitió seleccionar un conjunto de textos, siguiendo dos criterios.

Por un lado, como anticipé previamente, presentan una diferencia de grado en cuanto a la ubicación del relato testimonial en un campo de ficción. Esta gradación permite localizar en un extremo textos como Nunca más (Informe de la CONADEP), El flaco perdón de Dios, de Juan Gelman y Mara La Madrid, José de Matilde Herrera, y en el otro extremo, El fin de la historia, de Liliana Heker. Dentro del marco que diseñan estos textos se ubican obras que entiendo representan un crescendo hacia la actualización de la convención de ficcionalidad. Ellas son Recuerdo de la muerte y La memoria en donde ardía, de Miguel Bonasso.

Mientras tanto, este espectro textual ha sido organizado también en torno al núcleo temático, la memoria de la violencia de la década del setenta en la Argentina.

Aunque en los capítulos precedentes he realizado el análisis de estas obras en forma particular, se impone sin embargo la necesidad teórica y pragmática de ponerlas en diálogo, pues sólo en la interrelación se supera la textualidad para observar cómo se instituyen prácticas, sujetos y se producen sentidos que tienen efectos sobre el mundo cultural. 
La amplia gama de significados que la interacción dialógica entre estas obras genera, impulsa al lector a seguir el camino indicado por Pierre Bourdieu, quien afirma: "Buscar en la lógica del campo literario o del campo artístico mundos paradójicos capaces de inspirar o de imponer los 'intereses' más desinteresados, el principio de existencia de la obra de arte en lo que tiene de histórico, pero también de transhistórico, es tratar esa obra como un signo intencional habitado y regulado por algo distinto, de lo cual también es síntoma. Es suponer que se enuncia en ella un impulso que por la necesidad social del campo tiende a hacer irreconocible" 1

Con este propósito describiré en primera instancia los elementos que participan de la lógica de funcionamiento del campo de producción cultural en el que se insertan las obras que constituyen el corpus. Luego, analizaré algunas de las novelas con las que comparten el campo literario de fin de siglo, a las que seleccioné porque a mi juicio reúnen ciertas condiciones representativas de la Nueva Novela Histórica.

\section{I - Diálogo interdiscursivo}

Poner en diálogo las obras de Miguel Bonasso Recuerdo de la muerte y La memoria en donde ardía es un procedimiento que permite ampliar el horizonte de sentidos ya que se instalan algunas cuestiones a las que me he referido anteriormente y que han sido abordadas desde otras prácticas discursivas. En efecto, el lector se encuentra inmediatamente ante dos conceptos, "memoria" y "recuerdo", cuya relación desarrollada desde el punto de vista de la filosofía de la historia ${ }^{2}$ plantea que la memoria supone el recuerdo y el olvido. Al respecto, es importante deslindar el concepto de memoria que subyace en esta afirmación. Es entendida como una mirada sobre el mundo, como un construcción que actualiza el pasado y se materializa en el relato. Es así como adquiere un lugar principal en la conformación de la identidad de la sociedad.

En el caso de las obras de Bonasso, es posible a mi juicio concluir que trascienden lo individual para abarcar lo social, como ha quedado demostrado en su análisis (ver Capítulo II), y por eso podemos afirmar que se construyen a 
partir de la memoria colectiva, la que semánticamente hablando está sustentada en la violencia y su correlato: el surgimiento de una nueva categoría cultural, los "desaparecidos". En tal sentido, puede decirse que estas obras literarias se constituyen en "lugares de memoria" ${ }^{3}$ discursivos y que al mismo tiempo operan como una forma de pensar el presente. Recordemos que ese presente se sitúa en el fin de siglo.

Por otra parte, la novela testimonial y su marcada relación con el periodismo, tanto por sus rasgos discursivos como por las condiciones de producción, señalan un problema, el de "la verdad". Sin ingresar en un planteo epistemológico o filosófico sino pragmático, enunciando los recursos que la narración usa para legitimar lo dicho: la confesión, la carta, el testimonio. No obstante, los referentes de la novela, como por ejemplo Nunca más y el campo literario escritural, neutralizan cualquier sospecha del lector sobre la fiabilidad de la información que las obras brindan, pero se gesta entonces un nuevo pacto de lectura. El lector no busca la verdad de los hechos, ampliamente difundidos por los medios de comunicación y por otros textos con pretensión de veracidad, sino que se encuentra con una evaluación de la historia desde tres perspectivas: la que como lector individual debe desentrañar en el cuerpo de las novelas; la que otros lectores han realizado y que el texto explicita y la que efectúa el mismo autor. Este último es el que ubica a las obras en el pensamiento del "fin de siglo", pues se vuelve hacia el pasado para mostrar sus efectos sobre el presente y destacar las carencias, la impunidad, la traición.

En Recuerdo de la muerte se dice: "Si la conciencia colectiva no logra exorcizar a los demonios, el futuro será un tembladeral", y La memoria en donde ardía relata la trayectoria de esa búsqueda. Deja, de este modo, una pregunta en el lector, ya formulada por el filósofo Yerushalmi: “¿Es posible que el antónimo del olvido no sea la memoria sino la justicia?". 4

Las novelas de Bonasso comparten este campo cultural finisecular con otros textos que responden a diversos géneros y que mi lectura pone en diálogo. El marco sustancial está conformado por Nunca más y La voluntad, de Eduardo Anguita y Martín Caparrós.

Del primero me interesa destacar su función, pues le otorga credibilidad a los testimonios que ambas novelas ficcionalizan y al mismo tiempo su 
citación en esos textos actualiza la lectura, tanto en lo semántico como en los aspectos pragmáticos. Es así como alcanza un público diferente por sus características sociales y por su amplitud. Reingresa a la reflexión intelectual a través de la institución literaria, desprovisto de prólogos o intermediarios, tan sólo con la voz de las víctimas que dan testimonio. No es mi intención desconocer la presencia de un investigador ni de su intervención entre oralidad y escritura sino que a mi criterio, en esta recontextualización que produce la novela, el problema no es significativo.

La cita del Informe de la CONADEP conlleva la valoración que la sociedad le otorgó en la década del ochenta. Su función en el campo jurídico lo transformó en un texto sobre "la verdad" de la represión, hechos que expuso ante la opinión pública de nuestro país y del resto del mundo. No obstante, lo que el lector no puede perder de vista es que el carácter testimonial no lo inscribe como una escritura marginal, pues respondió a un objetivo político reclamado por la sociedad y asumido por las autoridades nacionales.

En este sentido, me interesa destacar la presencia en las novelas de Bonasso de otro texto que desde el margen y en la década del setenta representó a la represión en todos sus alcances; se trata de la "Carta abierta de un escritor a la Junta Militar", de 1977. Su autor, Rodolfo Walsh, reiteradamente mencionado en estas obras, plantea la escritura desde el lugar de la víctima y de la resistencia. Dice Walsh:

"Éstas son las reflexiones que en el primer aniversario de su infausto gobierno he querido hacer llegar a los miembros de esa Junta, sin esperanza de ser escuchado, con la certeza de ser perseguido, pero fiel al compromiso que asumí hace mucho tiempo, de dar testimonio en momentos difíciles". 5

Este texto, largamente silenciado, es recuperado por la novela y asume en ella un carácter paradigmático. Su estilo epistolar inspira, sin duda, pasajes como la carta de Tucho en Recuerdo de la muerte, por citar un ejemplo. Pero tal vez su significado más profundo, es que le permite al autor explicitar desde la autorreferencialidad sus postulados acerca de la función y efecto de la palabra en los diferentes contextos políticos de nuestro país. Así demuestra 
que la escritura une la voz y el cuerpo en un mismo destino: decir o callar, vivir o morir, respectivamente.

La mención de Rodolfo Walsh es una estrategia argumentativa que le permite a Miguel Bonasso sostener su tesis sobre la novela, que se revela cuando expresa:

“La narración muestra, no demuestra. La novela permite desenterrar ciertos arcanos que a veces se niegan a salir dentro de las pautas más racionales de la crónica histórica, el testimonio de denuncia o el documento político [...] y recuerdo unas palabras felices de mi maestro Rodolfo Walsh: 'si en algún lugar escribo 'hice', 'fui', 'descubrí, debe entenderse 'hicimos', 'fuimos', 'descubrimos'." (Págs. 443-444, Recuerdo de la muerte)

En cuanto a La voluntad, considero que si bien no es un texto citado en la novela porque es de publicación posterior, su condición como referente virtual para conformar la competencia del lector es relevante. Su lectura constituye un "saber" a partir del cual el lector puede deconstruir las novelas de Bonasso, más que interpretarlas. Por citar un ejemplo, es reiteradamente mencionada Graciela Daleo, como modelo de la juventud comprometida con los ideales de los setenta, como paradigma del combatiente que no cedió ni aún frente al indulto ya en épocas de democracia. El alcance de este procedimiento del escritor trasciende lo informativo y documental para situarse en lo ético. No puede un lector desprevenido comprender, en el sentido bajtiano del término, si no ha accedido previamente a la biografía novelada de Graciela Daleo que se relata en los dos tomos de Anguita y Caparrós.

Los autores comparten con Miguel Bonasso una profunda admiración por la militancia de la juventud de los setenta. Sin embargo, no es su intención volver al pasado desde el sentimiento sino conocerlo, pues según expresa en Recuerdo de la muerte: "No se puede construir una genuina convivencia democrática sobre cimientos de iniquidad y vergüenza” (pág. 467).

También en La memoria en donde ardía expone su proyecto creador: "Porque estoy seguro de que mientras una sola conciencia, como la de la Abuela Leonor de Plaza de Mayo y de estas páginas, siga alimentando esas llamas, los muertos no estarán solos y los jóvenes podrán recobrar el pasado 
que hoy se les niega, no para imitarlo de manera servil o suicida, sino como puente imprescindible hacia el devenir" (pág. 14). En esta tesis de Miguel Bonasso ficción y teoría se interceptan en un punto de acuerdo: el relato abarca la temporalidad humana y al constituirse en un puente entre pasado y futuro produce su efecto político en el presente, pues, como dije anteriormente, la recuperación del pasado supone en la novela una evaluación que involucra al presente.

Efectivamente, el autor dice que la Argentina de hoy ha abandonado los ideales, la lucha política y la utopía de la revolución que signó a los setenta, para reemplazarlo por otro mecanismo que tiñe no sólo lo privado sino que se extiende a la esfera pública: la corrupción. El efecto es la disolución de toda la diferencia entre el espacio del delito y del poder. Se anula toda posibilidad de resistencia y por ende desaparecen los movimientos sociales o marginales. Desde esta perspectiva la revolución parece innecesaria, una utopía, afirmación ésta que encuentra su principal fundamento en la realidad que vivimos y que discursivizan los medios de comunicación social.

Convendría ahora dirigir nuestra atención a la obra de Liliana Heker. El fin de la historia es un texto que prefigura un lector modelo ${ }^{6}$ con competencias históricas y literarias, capaz de semantizar los espacios en blanco y que admite en su comprensión un horizonte cultural en el que incluye al emisor.

La configuración de esta obra parece secundar la intención de focalizar con otra luz la realidad representada, esto es comprender, valorar desde otro ángulo cultural una circunstancia histórica. Su explicación de lo histórico es absorbida en el prisma de una subjetividad que se multiplica y desplaza en distintos puntos de vista. Con este procedimiento plantea que a la confianza en la objetividad testimonial propia del discurso historiográfico se opone la confianza en la coherencia del mundo ficcional. No es difícil advertir que el autor es lector del relato histórico y como tal es un intérprete que hace dudosa la posibilidad de la historia como verdad. La escritura deconstruye la referencia histórica para construir un mundo posible. La literatura se conforma como transhistoria. 
Este marco general fundamenta una lectura que examina la obra en sus relaciones interdiscursivas. Si bien ya he trabajado los relatos testimoniales de reaparecidos por su valor semántico en la novela, creo que es necesario también establecer un diálogo con José, de Matilde Herrera. Tomaré esta obra como ejemplificadora para argumentar en torno a una hipótesis: la novela de Liliana Heker puede leerse como contradiscurso del relato de las Madres de Plaza de Mayo.

Con este objetivo es que delimitaré una estrategia de lectura que propone los siguientes pasos: En primer lugar, consignar el núcleo semántico de conexión que orienta la coherencia de los mundos posibles, luego conformar redes semánticas aplicando un criterio de relevancia y finalmente resemantizar la intercomprensión de los universos textuales y sus contextos comunicativos para que la lectura se diagrame no sólo en su dimensión de efecto individual sino también en su dimensión social y conforme una alternativa de interpretación de la representación de los hechos históricos.

De inmediato el lector detecta que el núcleo de conexión entre ambos relatos es la violencia y la represión que se ejerció durante el llamado Proceso de Reorganización Nacional, pero también advierte que cada obra, desde su peculiar configuración, parece comprender y valorar desde distintas perspectivas estos hechos históricos y su representación en el presente de la escritura.

Como ya hemos observado en José, existe silencio sobre la violencia de los grupos militantes, aunque se destaca la violencia del Estado, de tal modo que se desplaza el concepto de "guerra" hacia el de "terrorismo de Estado". Consecuentemente, asistimos a la disolución de la "teoría de los dos demonios".

En El fin de la historia esta teoría es el argumento implícito con el que se justifica la violencia en la voz de la militante revolucionaria-prisionera, quien habla apropiándose del discurso del represor. Se destaca de este modo la traición como nota específica del relato.

No obstante, más allá de las perspectivas ideológicas desde las que se evalúa la violencia, ambas obras hablan de un Estado totalitario que ha 
desterritorializado al sujeto y cuyo instrumento más efectivo es el terror. A partir de esta matriz de sentido (violencia-totalitarismo) que, como he expresado, vincula a las obras en un sistema disciplinar literario e histórico, es posible conformar una red semántica. Los núcleos generadores de la coherencia de los mundos posibles descansan sobre un eje: la dicotomía héroe-antihéroe.

En José el lector construye la historia de vida de un protagonista que encarna la imagen del héroe fundada sobre los siguientes aspectos:

* sus condiciones de líder natural y militante revolucionario por convicción.

* su fidelidad a los ideales del movimiento revolucionario, a las metas sociales de su militancia, que se demuestra en la coherencia entre decir-hacer.

* su condición de "desaparecido" por una causa única que lo victimiza: su militancia política.

Mientras que en El fin de la historia, ante diferentes estrategias textuales, el lector reescribe otra historia de vida, la de Leonora, quien encarna la imagen de antihéroe, pues representa la negación de los valores que orientan la conducta y el ser de José y presupone las siguientes características:

* en sus condiciones personales predomina el individualismo y la búsqueda de protagonismo.

* su militancia es una conducta adolescente primero, y luego un entretenimiento burgués.

* traiciona los ideales del movimiento.

* su condición de reaparecido y exiliado la desplaza del lugar de la víctima.

* su éxito individual y privado implica el fracaso de la acción social y colectiva.

Así, desde la negatividad, esta novela afirma la representación previa de los valores que conforman la moral, que tiene vigencia en la sociedad del presente de la escritura. 
En el horizonte del lector no puede estar ausente el emisor y su situación de enunciación, por lo que es imprescindible señalar que son voces femeninas las que esgrimen los argumentos que sostienen estas ideas que he enunciado. Entiendo que éste es un aspecto que merece atención especial.

En la novela se cuenta la historia de una mujer militante. Esta imagen de la mujer revolucionaria se gesta en los años sesenta, aunque su antecedente se encuentra en la figura de Eva Perón ${ }^{7}$. Sin embargo, subsisten en ella otros modelos que la devuelven a la esfera doméstica: la mujer esposa y madre, centro de las relaciones familiares como espejo de los intereses del hombre y esta metamorfosis constituye lo antiheroico, pues es la negación de la imagen de la mujer combatiente que opera en el imaginario social. Sus paradigmas son, por un lado la mujer revolucionaria, hija y madre que muere por sus ideales, representada por María Victoria Walsh ${ }^{8}$, y por otro lado la madre-mujer combatiente, imagen instalada por las Madres de Plaza de Mayo. ${ }^{9}$

Mientras tanto, como se ha visto, en José la voz narradora de Matilde Herrera encarna el ideario de las Madres y la escritura es tal vez la acción más representativa de su afirmación como madre-mujer combatiente que transformó su duelo en una praxis vital consecuente. ${ }^{10}$

Hasta aquí he analizado el relato de la representación de la violencia durante la dictadura militar en dos obras con diferente grado de ficcionalización del discurso testimonial e histórico, y en las que se ha demostrado que las diferentes perspectivas en la evaluación del pasado son sustanciales. Sin embargo, también lo son las diferencias de sus respectivos contextos de producción.

Una pertenece al campo intelectual y político de los ochenta, cuyas características he desarrollado en el tercer capítulo. La otra, se localiza en los noventa y se enmarca en la llamada Nueva Novela Histórica, inscribiéndose en las producciones culturales del fin de siglo, en el concepto de Josefina Ludmer (ver Capítulo I).

Si nos demoramos en el título, El fin de la historia, polisémico, por cierto, es interesante ver que puede constituirse en una clave de lectura que inserta a la novela en la línea de pensamiento representada por Francis Fukuyama en textos como “¿El fin de la historia?”"11 y que según Fredric Jameson constituyen 
lo que se ha dado en llamar el postmodernismo ${ }^{12}$. Al respecto es muy pertinente el análisis que efectúa Marina Pianca sobre el impacto que el discurso del "fin de la historia" tiene sobre la memoria y especialmente sobre lo que llama "la memoria del futuro".

Pianca propone que la política del olvido no se sitúa sólo en el pasado sino también en el futuro. Dice que "el retorno de lo reprimido -el retorno del horror- en este sentido estaría asegurado tanto por un pasado silenciado como por un futuro olvidado en un presente sin alternativa". ${ }^{13}$

Otra clave de lectura del título de la novela de Liliana Heker es considerarlo una referencia intratextual, como un sintagma alusivo a la relación entre ficción y política. Desde la autorreferencialidad de la escritura la novela está proponiendo una clausura del relato sobre la represión de los setenta, y para ello deconstruye los testimonios, desmitifica a los "desaparecidos" como víctimas, desplaza la representación de la culpa del sobreviviente por la adaptación al presente del reaparecido y exiliado.

Finalmente, creo que una rápida revisión nos facilitará una síntesis de la lectura de la novela, esbozando algunas conclusiones que se desprenden de su análisis.

La novela ficcionaliza la representación de la década del setenta, que han producido otros discursos como los testimonios de reaparecidos y la representación de estos testimonios que se indujeron en sucesivas lecturas especialmente signadas por el reconocimiento del pasado que se produjo en la década del ochenta, cuando la democracia hizo posible el recuerdo. En ese proceso de ficcionalización el lector encuentra una clave de lectura: la novela de Liliana Heker puede leerse como contradiscurso de los testimonios y también del discurso de las Madres, porque afirma justamente "el fin de la historia" y esto afecta a la "memoria del futuro".

Buscar las razones de lo que la obra dice y aún de lo que silencia orienta una lectura que intenta describir distintos factores que conforman el campo intelectual del fin de siglo en la Argentina. Un ámbito que se caracteriza por las tensiones entre ficción y política en el campo literario, y por la función rectora del campo periodístico sometido a las reglas de lo económico, enmarcado a su vez en lo político. Este espacio es lo que describiré seguidamente. 


\section{II - La novela en el campo literario}

El campo cultural de la Argentina de fin de siglo se presenta como un corpus heterogéneo de prácticas discursivas y artefactos culturales, en el que la novela impone su estatuto canónico. ${ }^{14}$

El testimonio ingresa al campo literario ficcionalizado en la novela y comparte ese espacio con otras modalidades de la Nueva Novela Histórica, a las que me refería en el primer capítulo: la metaficción historiográfica y la novela autobiográfica.

He explicado el auge de la Nueva Novela Histórica porque es un relato del fin de siglo que, entiendo, como lo hace Josefina Ludmer, es un "entre" que produce sus propios discursos culturales. Si bien su contexto de producción se puede localizar a partir de 1983, cuando el país entra en un proceso democrático, es en los noventa que alcanza su mayor difusión y se afianza con sus características propias (ver Capítulo I).

Sin duda para un lector contemporáneo ésta es una afirmación que no requiere una demostración exhaustiva; sin embargo, me parece pertinente señalar algunos acontecimientos que operaron en el contexto de recepción, para asegurar su circulación en estos últimos años. Me refiero a una política de investigación que en distintas universidades de nuestro país privilegió estudios sobre la relación entre literatura e historia ${ }^{15}$ y propuso para el análisis textos como La novela de Perón, de Tomás Eloy Martínez, o La revolución es un sueño eterno, de Andrés Rivera. También me parece un dato significativo que en 1996 recibiera el Premio Planeta la escritora María Esther de Miguel por su novela El general, el pintor y la dama, que ahonda en la vida privada de Justo José de Urquiza e integra una saga que la autora inició en 1993, con La amante del Restaurador (Premio Feria del Libro 1994 y Premio Silvina Bullrich 1995), y continuó en 1995 con Las batallas secretas de Belgrano.

Por otra parte, en 1997 se desarrolló en San Carlos de Bariloche el XV Simposio Internacional de Literatura cuyo tema central fue la novela histórica y la problemática relación entre historia y ficción. También en 1997 el Premio 
Planeta fue otorgado a Ricardo Piglia por la novela Plata Quemada, cuyo campo de recepción se extendió posteriormente al cine.

En este universo simbólico el discurso literario interactúa con el periodístico, y es entonces insoslayable recordar que La voluntad de Anguita y Caparrós es una obra ejemplificadora de las relaciones interdiscursivas entre periodismo, historia y literatura, lo que reforzó la hegemonía de una nueva narrativa en el campo cultural.

Por su parte, el periodismo, respondiendo a sus principios, tenía que decir sobre lo urgente que se desarrollaba en el campo político en la Argentina y así puso la historia al servicio del presente y en función de la denuncia.

Cobró importancia entonces la figura del escritor-periodista, como Hernán López Echagüe (El otro. Una biografía política de Eduardo Duhalde), Horacio Verbitsky (Robo para la corona; Hacer la corte; El vuelo), Gabriela Cerruti (El jefe. Vida y obra de Carlos Saúl Menem; Herederos del silencio) y Miguel Bonasso (El presidente que no fue. Los archivos ocultos del peronismo; Don Alfredo) y con ellos una producción que constituía una impugnación a toda clasificación genérica e instalaba tan sólo el relato.

La violencia del pasado y la corrupción en el presente, gobierno militar y democracia, el relato se hizo cargo de un tema unificador: el poder del Estado y el de la palabra que, transgrediendo todas las fronteras epistemológicas, mostró y demostró, resignificó los hechos para un público realmente heterogéneo. En este contexto la Nueva Novela Histórica que recupera el testimonio encuentra un espacio de producción y recepción fecundo; así se reedita en 1994 Recuerdo de la muerte y se publica en 1996 El fin de la historia de Liliana Heker, obras que integran corpus de esta investigación.

A pesar de que la escritura se constituye en una figura de red de influencias múltiples, es evidente que una de las cuestiones clave que cruza la zona estética y epistemológica es el relato que hace inteligible el mundo y donde se ve justamente que la ficción, en su representación discursiva, construye una versión de la sociedad argentina de fin de siglo.

Si bien la consistencia de esta hipótesis se apoya en asunciones teóricas ya desarrolladas, hay que recordar al mismo tiempo que la metaficción es una condición clave de la narrativa finisecular; por lo tanto, me propongo 
explicar aquí los alcances y los límites de esta afirmación mediante una reflexión sobre algunas de las obras mencionadas anteriormente, que acompañan significativamente a los textos que conforman el corpus. Me refiero a La novela de Perón, La revolución es un sueño eterno, Herederos del silencio y Plata quemada. Esta producción literaria posee rasgos comunes que sustentan su lectura como Nueva Novela Histórica; a saber: el carácter metaficcional, la interdiscursividad historia-ficción, la temporalidad y sus efectos sobre la relación memoria-olvido y la presunción de un lector con competencia cultural para reescribir el texto.

Si bien comparten estas condiciones, creo, sin embargo, observar variantes que enriquecen la relación historia-ficción y ejemplifican las distintas modalidades de la Nueva Novela Histórica que, recordemos, definí como metaficción historiográfica y novela autobiográfica.

En este marco La novela de Perón ${ }^{16}$ es un texto en el que puede leerse una concepción de la ficción y su efecto sobre el campo cultural y un relato del proceso total de la historia argentina, aspectos que la constituyen en una ficción orientadora de la relación literatura y política.

El pretexto claramente identificable en la novela, sin duda, son las memorias orales de Juan Domingo Perón, grabadas por Tomás Eloy Martínez. Éstas en sí mismas constituyen un palimpsesto de borraduras y omisiones, hechos y relatos contradictorios. $Y$, por otra parte, en la configuración de su mundo ficcional operan otros discursos como el periodístico, que en una compleja red de relaciones construyen una versión de la biografía de Perón que sirve de guía para contar una versión de la historia del Estado Nacional. La novela desde el mismo título retoma la tensión entre verdad-falsedad, realidadfantasía, y enuncia una posición frente a ella. Dice Tomás Eloy Martínez: "Ha sufrido pensando que la historia contará a su manera lo que él calló. Aún vendrán otros a inventarle una vida ... un hombre solo es lo que de él se recuerda..." (pág. 103).

El texto exhibe una concepción de la escritura y de la lectura en su propia conformación discursiva cuya matriz es la intertextualidad, la citación de diferentes tipos discursivos, siempre a través de la lectura de los distintos personajes. Señalaré tres de ellos como estructurantes: las Memorias de Perón 
y la revista Horizonte, presentados como "memorias" y "contramemorias" respectivamente, y los testimonios que se manifiestan en evocaciones y relatos escritos.

Las Memorias representan una versión de los procesos políticos del país desde la perspectiva de un yo narrador, Perón, como protagonista o testigo comprometido; destacan la faz militar de Perón, su concepto del poder, su participación en el golpe militar de 1930. Dice Tulio Halperin Donghi que "Tomás Eloy Martínez procede en esto como si también para él los aportes esenciales de la experiencia histórica argentina fuese preciso buscarlos en la etapa formativa de la Argentina moderna". ${ }^{17}$

Las Memorias crean una historia de vida y a un hombre político. El lector se encuentra entonces frente a la otra novela de Perón, cuyo proyecto narrativo es recordar para la historia, construir un modelo acorde con las expectativas de su destinatario: el pueblo argentino. El procedimiento de escritura de las Memorias exhibe cuán lejos se halla de la verdad histórica y cuán cercana a la construcción ficcional.

En tanto, los artículos de la revista Horizonte dicen lo que las Memorias ocultan u omiten, las debilidades, las intimidades no ejemplarizantes, y lo hace a partir de un material, los recuerdos de los testigos. Su intención explícita es fundar un pacto de veracidad con el lector, verdad que sin embargo siempre se relativiza y se impugna cuando la lectura pone en diálogo las distintas voces y perspectivas de los hechos. Su intención está claramente expuesta en la novela: "El periodismo es una profesión maldita. Se vive a través de, se siente con, se escribe para ... Quiero contar lo no escrito ... desarmarme de la historia para poder armarme al fin con la verdad." (pág. 261).

En cuanto a los testimonios, se presentan en la novela para mostrar otra versión de los hechos contados por las Memorias en algunas ocasiones o por la revista Horizonte en otras. Constituyen una estrategia narrativa para otorgarle legitimidad documental a lo narrado; sin embargo, la novela impugna ese estatuto de veracidad fundado en la correlatividad de testigo-actor y juez. Claro ejemplo de ello es el testimonio de María Tizón, que ofrece dos modalidades discursivas. Por un lado, la evocación del diálogo con Benita, espontáneo, íntimo y documentado por las cartas personales que actúan como 
textos probatorios. Por otro lado, el relato para la prensa, que contradice absolutamente sus recuerdos. Se nos dice así una vez más que cuando la escritura expone lo privado a lo público crea su propio objeto.

Este breve análisis de la obra de Tomás Eloy Martínez ha intentado demostrar cómo la novela representa los discursos que circulan en la sociedad y que establecen una compleja red de relaciones con las prácticas sociales, cuyo efecto resultante es la construcción de un imaginario social acerca de la figura de Perón y de hechos clave para la historia argentina. El lector asiste a una deconstrucción del pasado, desde el imaginario del presente de escritura (recordemos que es en los ochenta) construido a lo largo de un proceso. Se hace evidente que el mundo simbólico se configura en la interdiscursividad entre discurso histórico y discurso literario, pero se apoya en la mediación del discurso periodístico de la radio, la televisión y la prensa gráfica, para construir distintas versiones de los hechos del pasado.

A mi juicio, ésta es justamente la particularidad de La novela de Perón: mostrar las potencialidades de la interacción del discurso periodístico con el discurso literario e histórico en la construcción de la realidad.

Si bien la obra de Tomás Eloy Martínez ofrece un rico espectro de análisis como manifestación de la Nueva Novela Histórica, es en La revolución es un sueño eterno ${ }^{18}$ de Andrés Rivera donde creo posible observar otros matices que me parece vale la pena analizar.

La obra de Rivera toma como referente a un sujeto del acontecer histórico, Juan José Castelli, para incursionar en lo biográfico a través de la forma del diario y, como en la novela de Tomás Eloy Martínez, esta figura resulta paradigmática para mostrar la historia nacional. La novela ficcionaliza la historia, la interroga y resemantiza, tomando como tópico a la Revolución de Mayo, pero dejando abierto a la competencia del lector un profundo cuestionamiento acerca de la experiencia histórica de la nación.

El texto propone una clave de lectura fundada sobre cuatro preguntas que a mi juicio son estructurantes y cuyas respuestas se encuentran en el sistema textual: ¿Quién soy?, ¿Qué juramos el 25 de Mayo de 1810, arrodillados en el piso de ladrillos del Cabildo? ¿Qué juré yo?, y ¿Qué revolución compensará las penas de los hombres? Todas remiten a un mismo 
tópico, la definición y alcances de la Revolución, y sus respuestas establecen una vinculación entre pasado y presente.

La novela ejemplifica entonces la tesis de Paul Ricoeur de que el presente y el futuro pueden entenderse a partir de huellas que el pasado ha dejado y que el relato atraviesa la temporalidad humana, en tanto quiebra las coordenadas cronológicas para vincular presente-pasado y futuro.

Retomemos ahora la primera pregunta: “¿Quién soy?” y encontraremos que el texto ofrece las siguientes respuestas: "el orador de la revolución", "el que fuera representante de la Primera Junta en el Alto Perú", "el lengua cortada", "soy Castelli", "soy papel, pluma, tinta". Todas conducen a una misma relación, la equivalencia Castelli-palabra; remiten a la oralidad en el pasado y a la escritura en el presente de enunciación. Una escritura que reúne una característica que merece destacarse: es un diario, por lo tanto discursiviza la memoria individual y es privada, por lo que lo pone a salvo de toda sospecha y otorga la credibilidad de lo narrado. Sin embargo, el proyecto narrativo es resguardar esa memoria para que alguna vez trascienda en la esfera pública la narración contada desde el margen de la historia, desde los vencidos, desde los silenciados. De manera que la escritura se presenta aquí como una estrategia para resistir, tal como lo señala un principio que fue soporte de la Revolución de Mayo: "La revolución se hace con palabras, con muerte. Y se pierde con ella ..." (pág. 135). La evaluación del pasado identifica las causas del fracaso: hablar y matar. Entonces el lector se pregunta lo que el propio texto sin clausura ya ha hecho: “¿Qué revolución compensará las penas de los hombres?" Se anticipó una respuesta: la escritura, como el espacio en el que es posible "no confundir lo real con la verdad" (pág. 135). Y, finalmente, ¿Qué se narra en esta novela? La novela cuenta que Castelli escribe sobre la Revolución de Mayo de 1810, pero, sin embargo, el lector puede olvidar fácilmente ese dato, que podría tratarse de otras revoluciones más cercanas al momento de producción de la novela (1987). Lo cierto es que la ficción narra la fundación de una nación sobre un hecho en el que se aúnan la violencia y los conflictos de poderes.

La segunda pregunta que articula la narración: "Qué juré yo?, vuelve sobre la Revolución como experiencia histórica argentina. Es un interrogante 
con un doble destinatario, el propio Castelli y el lector, que encuentra una respuesta metafórica: “Juré que la Revolución no sería un té servido a las cinco de la tarde" (pág. 158). Otro argumento completa el anterior, el que realiza ante Segundo Reyes, un esclavo, un vendedor de pescado, un capitán del Ejército. Así se lee en voz del narrador:

"Dijo que recordaba al doctor Juan José Castelli en el Ejército del Alto Perú, jurándole que un hombre libre es igual a otro hombre libre y que donde fuesen las armas de la libertad darían tierra, pan, trabajo y escuelas a blancos, negros e indios ..." (pág. 105).

El juramento que motivó la Revolución fue la Igualdad y la Libertad, y en eso fracasó. El narrador expresa:

"Dijo que el vendía pescado ... Dijo que los señores Anchorena no vendían pescado..." (pág. 106).

Sin embargo, dos aspectos permanecen al margen del fracaso, en esta deconstrucción de la historia que produce la ficción: la identidad del político y la fraternidad del líder revolucionario.

Esta novela dialoga con el pasado para leer el presente ${ }^{19}$. En ese presente los proyectos de cambio se disuelven; la revolución es una utopía, la muerte una herida demasiado próxima para ahondar en ella; la injusticia y la impunidad generada por el poder, una realidad candente.

El antecedente documental de la novela es el Documento del Juicio del Desaguadero que se recontextualiza para refutarlo. Esta operación pone en crisis las versiones oficiales y le otorga a la literatura la capacidad de construir mundos alternativos. En este ejemplo adquiere sentido una expresión de Nicolás Rosa: “La literatura dice lo mismo que la historia, pero la literatura dice más”. La ficción levanta una crítica a la institución jurídica, a la corrupción que pone al servicio del poder. Tanto en el juicio a Castelli como en el presente de escritura, la justicia afronta una crisis de credibilidad. Pero por sobre todo lo que acerca el pasado al presente es la función del Estado, que se constituye, a partir de los poderosos, sobre el silencio y la arbitrariedad, olvidando uno de los principios básicos de la democracia: el derecho de igualdad ante la Ley.

En suma, esta novela se constituye en una metaficción historiográfica estableciendo una relación interdiscursiva entre historia y ficción, cuya 
resultante es un efecto político sobre el presente de escritura y el futuro de lectura, por lo que resemantiza la experiencia histórica argentina.

Las novelas de Tomás Eloy Martínez y Andrés Rivera forman parte del campo cultural de fin de siglo porque la lectura las pone en circulación y así coexisten con otros escritos de este tiempo, como Plata quemada de Ricardo Piglia.

La novela de Piglia también pertenece, a mi juicio, a la Nueva Novela Histórica por su carácter metaficcional, por establecer relaciones interdiscursivas entre ficción e historia por mediación del discurso periodístico y por su concepción de la historia. En el epílogo, el autor plantea una tensión entre ficción-realidad cuando dice: "Esta novela cuenta una historia real ..." (pág. 245). El relato ficcional se hace cargo de una realidad, pero sin embargo no de la verdad. Se insiste sobre la fidelidad de los hechos, pero el texto se encarga de demostrar en su funcionamiento que la verdad es discursiva. Así, por ejemplo, la incorporación del cronista en el capitulo cuatro, introduce en la historia una instancia interpretativa, por lo que el hecho real se convierte en un fenómeno que en tanto tal no pierde consistencia, pero en tanto interpretado despliega todas las potencialidades del relato y de los sujetos sociales que se hacen cargo de él y le otorgan sentido.

La "historia real" en cambio es una huella, es un documento que la novela explicita: la crónica periodística. Es justamente ese documento producido por el poder el que la novela cuestiona y en ese gesto impugna también su verdad. En el texto, el discurso periodístico opera en el presente de enunciación dándole actualidad a los acontecimientos narrados, pero la prensa tiene también otra función, es un mediador entre delincuentes-policías, es un formador de opiniones y ambos sectores son conscientes de la importancia de la recepción. Es el único instrumento de comunicación entre ellos.

La información periodística es "creada" para producir una conducta en el receptor. Tiene un destinatario inscripto, los delincuentes, y un emisor desde el poder, la policía. Por lo tanto no existe coincidencia entre emisor-locutor ni receptor-alocutario, de modo que la intención del acto del habla desplaza lo informativo hacia lo performativo, el periodismo escrito se presenta como un instrumento de las instituciones políticas y administrativas del Estado. 
Es importante destacar también que la narración produce una estilización del discurso periodístico, y con este procedimiento hace una crítica a su función social. La estilización mencionada se logra por:

* el detallismo descriptivo, morboso, de la acción violenta: "y su rostro quedó convertido en una cavidad sangrante" (pág. 56)

* la manipulación del sentimiento del público que logra cuando transfiere lo privado a la esfera pública: "Boca arriba...agonizaba...el oficial de treinta y dos años, con dos hijitos que van a quedar huérfanos de padre" (pág. 165), o también recurriendo a valores estereotipados como la niñez asociada a lo angelical o el provinciano trabajador que busca su horizonte en la ciudad. Todos presentados como víctimas inocentes mientras que la contrapartida es la sobredimensión del acto delictivo y sus alcances morales.

* la exageración de la crueldad y la violencia en la venganza que genera una estética de la muerte, que trasciende los lugares comunes del relato policial.

En esta disociación de verdad-realidad Piglia se opone al pensamiento historiográfico tradicional y capta una concepción de la historia que acepta el carácter ficcional de su discurso, ${ }^{20}$ la estrecha relación entre historiografía y periodismo, y que en lo real representado se introduce el presente y se organiza así la representación.

En otro señalamiento metadiscursivo dice el escritor: "He tratado de tener presente en todo el libro el registro estilístico y el gesto metafórico de los relatos sociales cuyo tema es la violencia legal" (pág. 245-246). Instala aquí dos relatos históricos, el oficial que se produce desde el poder y el que se genera desde la heterogeneidad social y desde donde se cuestiona la homogeneidad del sistema de representación social del Estado burgués. En este último se inscribe la concepción de la historia que sostiene la Nueva Novela Histórica.

Desde este punto de vista la novela capta el debate en torno a la concepción del pasado y despliega frente al lector un profundo cuestionamiento 
sobre la sociedad. El tema central es el poder y las responsabilidades ante el efecto social de violencia.

La violencia de los delincuentes es explícita, pero se presenta como un síntoma. La causa es la violencia endémica de la sociedad, que se manifiesta en:

* la familia, que denuncia y produce el extrañamiento de un integrante. Quiebra un vínculo como negación del amor.

* el hospital, que objetiviza al sujeto como un recurso experimental, restándole pensamiento y sentimiento, negando la vida.

* la cárcel, que produce una degradación de la persona, al punto de que se lo reduce a su condición animal, donde la tortura se homologa al silencio y cuya contracara es la justicia y la palabra, por lo que se presenta como una forma de resistir al poder.

* la policía, que se confunde con los delincuentes en un juego de violencia-contraviolencia sobre el que el texto abunda e incluso ironiza.

* las instituciones políticas, que se tiñen de indeterminación en su rol y claramente están identificadas con la corrupción.

¿Cuál es la respuesta de la sociedad que el texto plantea? La hipocresía centrada en la falsa caridad hacia el prójimo y la violencia como venganza, que es contraviolencia colectiva. Una sociedad masificada que no comprende sino lo aparente. Su juicio está focalizado en una relación binómica de opuestos: delincuente-policía, culpable-víctima, delito-justicia, que es ficcional, creada por el discurso de actualidad periodística y el funcionamiento de las instituciones que identifica culpabilidad con responsabilidad.

La culpabilidad es amoral: la violencia no tiene objeto pues el valor del dinero desaparece en la quema, porque la marginalidad es la locura y ésta consiste en la "imposibilidad de dilucidar la raíz moral de los hechos de su vida ..." (pág. 56), mientras que la responsabilidad se diluye en el fragmentarismo del texto y en la multiplicidad hermenéutica.

Finalmente, la novela relata la historia contada desde el margen que permite pensar una sociedad en cuyo centro se instala un debate sobre la trama del poder, la heterogeneidad que elimina los binomios, la 
desterritorialización del sujeto individual y social, la creación del mundo que produce el lenguaje mediático y la transposición de lo privado a la esfera pública. Es así como la sociedad representada parece sostenerse sobre la negatividad de los valores que tradicionalmente conformaron su código de vida y su ética.

He mencionado en reiteradas oportunidades a la novela autobiográfica como una de las modalidades de la Nueva Novela Histórica. Me interesaría detenerme en una de ellas que, publicada en 1997, servirá de ejemplo y que completa además esta descripción del campo literario de la Argentina de fin de siglo que he esbozado hasta aquí. Se trata de Herederos del silencio, de Gabriela Cerrutti.

Si bien esta novela ofrece múltiples alternativas de lectura, no es mi intención realizar un análisis exhaustivo, pues excedería los límites de este trabajo. Mi propósito es observar la configuración del mundo ficcional a partir de la identidad del sujeto narrativo, y de la interdiscursividad entre historia y ficción.

En primera instancia creo conveniente fundamentar mi afirmación inicial de que se trata de una novela. Al respecto, y para no abundar en detalles ya desarrollados anteriormente, ${ }^{21}$ es necesario recordar las condiciones propias del texto: se trata de un relato ficcional autobiográfico cuya matriz constitutiva es la intertextualidad y la interdiscursividad. ${ }^{22}$

Su carácter ficcional es definido por la misma autora, quien dice en el paratexto: “... este libro guarda apenas la versión de la historia tal cual vive en mi memoria, más o menos cercana a la verdad, según el momento" (pág. 244), cerrando de este modo la obra.

Por un lado, se puede decir que la ficción se localiza en la brecha que hay entre la realidad y la verdad, para crear un mundo que pudo ser, desde la perspectiva de un sujeto. Por otra parte, el relato quiebra la cronología propia de la narración histórica para captar la temporalidad, que la narradora hace posible cuando compara un hecho o un sujeto del pasado con su proyección en otros tiempos de su vida y aún en el presente de enunciación. Así es como del relato de los setenta anticipa lo que ocurrió en los ochenta desde el tiempo de 
enunciación, 1997, y produce una simultaneidad del pasado con el futuro que no es más que su presente.

La afirmación de la subjetividad es un rasgo natural del proceso narrativo del texto. El lector puede seguir su trayectoria y observar sus dos formas de manifestación, en primera persona del singular y en plural.

Sin duda, la primera persona del singular establece, mediante un pacto de lectura que identifica al autor con el narrador, la condición autobiográfica de la novela. ${ }^{23}$ De la mano de esta práctica se narra la vida privada e ingresa al mundo ficcional la cotidianidad de ese período de la historia argentina, simbolizado con la música, las revistas, los diarios, los programas de televisión, el deporte y el cine. Todo ello es constitutivo de una cultura popular en la que el lector puede reconocerse. Sin embargo, lo autobiográfico es sólo un soporte para mostrar la vida política del país durante las últimas tres décadas del siglo.

En cuanto a la primera persona del plural, involucra un "nosotros" que tiene una identidad textual: los jóvenes de la Acción Católica, los hijos de civiles, los hermanos de una familia conservadora de costumbres burguesas y una generación a la que la autora califica como "los del medio, los que no fuimos reprimidos ni represores". Con ellos se identifica, en el plano discursivo y también en el actancial cuando el yo narrativo establece un triángulo con Cristina y María Elena, quienes sintetizan las posiciones políticas de los distintos sectores sociales, la indiferencia y la adhesión al proyecto militar, respectivamente.

En el movimiento entre yo-nosotros lleva la historia individual al terreno de lo colectivo, y la expresión más firme de este propósito se encuentra en la carta dirigida al lector como Postdata. En un tono amistoso, coloquial, le cuenta su trayectoria personal para invitarlo a conservar la memoria de pasado "sobre la que intentamos construir nuestro presente" (pág. 238).

La obra de Gabriela Cerruti pertenece a la Nueva Novela Histórica por su concepción del pasado. El pasado está en el discurso periodístico, en el discurso político, en el diario del abuelo, es siempre discursivo, y frente a él el sujeto autobiográfico se vuelve sujeto hermenéutico. Lo que permite concluir que esta novela produce una evaluación del pasado a partir de la 
interdiscursividad y la intertextualidad, que mencioné como matriz constitutiva del texto.

En cada capítulo se presenta un discurso dominante: el relato autobiográfico en el capítulo primero, una novela enmarcada en tercera persona en el segundo capítulo; una investigación periodística y documental en el quinto, y el discurso político del sexto.

He dejado para el final de esta enumeración el tercer capítulo, pues entiendo que es el eje sobre el cual opera la selección de la memoria narrativa. Allí se plantea la tesis que orienta este proyecto narrativo: la represión militar de los setenta tuvo efectos sobre la vida privada y la cultura popular. El artífice fundamental de los cambios fue el miedo, que afectó la relación pedagógica entre padres e hijos, y recluyó a la familia en el interior de sus casas. Consecuentemente el mundo se fragmentó en dos realidades, la simbólica y discursiva que llegaba a la gente a través de la televisión y la prensa escrita, y la experiencia de vida, los hechos de tortura y desaparición de personas. Todas las modalidades discursivas y las perspectivas narrativas están al servicio de la demostración de esta tesis.

Pero es quizá la intertextualidad el procedimiento más contundente para generar una evaluación del pasado que efectivamente da cuenta de un proceso histórico y político. En este gesto responde a la tradición literaria, pues como sostiene Silvia Molloy en un excelente estudio sobre la escritura autobiográfica hispanoamericana, una de sus características ha sido la vacilación entre persona pública y yo privado, entre sujeto y patria. La investigadora propone "ver esta preocupación nacional como espacio crítico marcado por una ansiedad de orígenes y de representación, dentro del cual el yo pone en escena su presencia y logra efímera unidad". ${ }^{24}$

El presente de escritura condiciona la aproximación al pasado, por eso en el texto se citan dos obras relevantes por sus efectos sobre el campo cultural de fin de siglo al abordar el tema de la violencia y la represión de los setenta. Son ellas El vuelo, de Horacio Verbitsky, y Recuerdo de la muerte, de Miguel Bonasso. Operan también en el texto, testimonios y documentos que fueron rescatados y producidos durante la década del ochenta, y no está ausente la citación de artículos periodísticos. 
Estas citas se introducen en el cuerpo textual en yuxtaposición con el relato de los hechos. La escritura descansa la responsabilidad de elaborar los sentidos sobre el lector y pone de esta forma en evidencia la contradicción que sufrió la sociedad durante la represión, contradicción ésta que creó una oposición entre discurso y acción, entre el mundo cotidiano y el mundo de los sótanos, el adentro y el afuera del país, la vida familiar signada por el miedo y la vida pública creada por las revistas.

Con esta operación, la novela reconstruye el clima de los setenta y también la representación que el imaginario social de los ochenta produjo sobre la época, por eso cuenta la nostalgia del espíritu revolucionario de aquella juventud pero también habla del sinsentido de tantas muertes, a la luz del espectro político de los noventa.

El sujeto narrativo reflexiona sobre el aislamiento, la soledad, el silencio de la sociedad frente a la represión, y la novela ofrece una explicación que pone al lector frente a la historia de la nación: los inmigrantes que huyeron de las guerras fundaron la nación, su objetivo era la supervivencia, y la sociedad argentina no perdió nunca ese gesto fundante. Herederos del silencio es una novela autobiográfica en la que el lector encuentra un mundo en el que se reconoce, no sólo por su aproximación al pasado sino sobre todo porque constituye una explicación de su presente.

Las novelas presentadas hasta aquí, tan sólo con una intención ejemplificadora de la constelación en la que se encuentra el relato testimonial, han presentado distintos matices en las relaciones interdiscursivas de la literatura con la historia y el periodismo, que a su vez mostraron una diversidad de problemas teóricos en torno de la ficción, aunque ofrecieron al lector planteos del orden de lo político.

Sin embargo, quisiera centrar ahora mi atención sobre la cuestión que es esencial a mi investigación. Obviamente, la descripción de este campo literario no estaría completa si no se explicitan las funciones del relato testimonial. Por consiguiente, volveré sobre el corpus de esta investigación para recuperar aquellas conclusiones que contribuyen a elaborar una síntesis final. 


\section{Notas}

1 Bourdieu, Pierre. Las reglas del arte. Génesis y estructura del campo literario. Barcelona, Anagrama, 1995, pág. 15.

2 En Les lieux de memoire. Gallimard, París, 1984, Pierre Nora plantea que la memoria supone al recuerdo y al olvido. Tal es a mi criterio la vinculación que se establece en las obras de Bonasso.

3 Pierre Nora llama "lugares de memoria" a aquéllos donde se encarna selectivamente el pasado de un pueblo y que por voluntad de los hombres o el trabajo de los siglos quedaron como los símbolos más notables. Estos lugares hay que entenderlos en todos los sentidos de la palabra y desde el más material, como los monumentos, hasta el más abstracto e intelectualmente construido. Es justamente este último caso el del discurso literario. (opus cit. págs. 1-16)

4 Yerushalmi, J. Los usos del olvido. Nueva visión, Buenos Aires, 1987, pág. 26.

${ }^{5}$ En "Carta abierta de un lector a la Junta Militar", de Rodolfo Walsh. (En La literatura de ideas en América latina. Ediciones Colihue, 1993, pág. 141).

6 Concepto de Umberto Eco desarrollado en su obra Lector in fábula. La cooperación interpretativa en el texto narrativo. Barcelona, Lumen, 1987, págs. 73-89.

${ }^{7}$ Kathleen Newman afirma que en la Argentina el fortalecimiento del feminismo está ligado a la política de izquierda y al peronismo, encarnado en la figura de Eva Perón, que se convirtió en un referente de la conceptualización de la mujer en la sociedad. Sin embargo, hubo una reevaluación del papel de Evita en las décadas del cuarenta y del cincuenta. En el sesenta se produce la revolución social, lo privado se vuelve público, pero no representa un desafío al orden patriarcal. En los setenta los conflictos del gender system se intensifican. "La guerra sucia que, en varios sentidos, era una 'guerra de clase', es un resultado de la agudización de los antagonismos que surgen en la década del sesenta y del setenta”, dice Newman (La violencia del discurso, págs. 118-120).

$8 \quad$ Kathleen Newman señala que "se trata de la muerte de la hija de Rodolfo Walsh que éste crea para la posteridad en una carta pública dirigida a sus amigos [...]. La imagen de la mujer combatiente combina ... lo político y lo (presuntamente personal). María Victoria Walsh ... ejerce un doble desafío a la sociedad en tanto combatiente y mujer 'nueva'. Estas dos identidades no pueden separarse: murió como combatiente y como mujer" (opus cit., pág. 26)

9 Laura Rossi en un artículo que tituló “¿Cómo pensar a las Madres de Plaza de Mayo", centra su reflexión en torno a la "locura" de las Madres entendida 
como "la racionalidad de la alienación entre Historia y Cotidianidad, Cultura y Naturaleza". Pero también, a la inversa -dice- "la fisura de esta división constituye como racional a aquella "locura". Cuando la represión militar produce el quiebre entre valores racionales y valores familiares, comienzan a enfrentar las formas mistificadas de relaciones sociales y "movidas por el amor a sus hijos, algunas mujeres se alzan para imponer el límite de puertas adentro del hogar a la cruzada patriótica militar que lo transgrede y lo desintegra. Es en la colisión entre lo público y lo privado donde se genera el punto de inflexión que instaura la 'locura”'. (En Nuevo Texto Crítico, № 4, Año I, Segundo semestre, 1989).

${ }^{10}$ Expresión de Marina Pianca, quien analiza los "fines" del postmodernismo desde la perspectiva de Derrida, como conjuras contra la posibilidad del retorno del espíritu del marxismo y señala la existencia de "herederos de la responsabilidad de revivir las promesas suspendidas que revienen del futuro ... la responsabilidad de una deuda...La justicia es irreductible y la deuda imborrable, dijo. Y ambas interpelan a los herederos de la promesa con una mirada que retoma el futuro. Las Madres de Plaza de Mayo -las 'locas' de la Plaza- ya nos habian enseñado esta lección al hacer de su duelo un proyecto, al hacer de su duelo una praxis vital consecuente que las transformó mientras transformaban el miedo en desafío". De "La política de la deslocación (o retorno a la memoria del futuro)", pág. 127. (En Memoria colectiva y políticas del olvido. Rosario, Beatriz Viterbo Editora, 1997).

${ }^{11}$ Fukuyama, Francis. "The End of History?". En The National Interest. Número 16 (verano 1989) Baltimore, Maryland. National Affaurs, Inc.

12 Jameson, Fredric. Postmodernism or The Cultural Logic of Late Capitalism. Durham, Duke University Press, 1991.

13

Pianca, Marina, opus cit., pág. 116.

14 No debemos olvidar que el canon se vincula a la identidad y a la tradición que se desea conservar y transmitir. En este sentido Mark Currie sostiene que "el canon literario fue un 'gran relato' en tanto representa la historia de la literatura como una narración lineal que se construyó generando exclusiones". (En Postmodern narrative theory. United States, St. Martin's Press, Inc. 1998, pág. 108. La traducción es mía).

${ }^{15}$ Me refiero a proyectos de investigación desarrollados y aún en curso en universidades como la Nacional de Salta, o la del Comahue, en cuyo marco se trabajaron las obras de Tomás Eloy Martínez y de Andrés Rivera, por ejemplo. En cualquier caso, se contempla un postulado que como advierte Elisa Calabrese en su sagaz estudio sobre historia y literatura titulado Itinerarios entre la ficción y la historiografía. Buenos Aires, Grupo Editor Latinoamericano, 1994: “... la novela histórica, en sus desplazamientos contemporáneos, lejos de ubicarse en relación de dependencia intentando imitar la producción discursiva de la 'verdad histórica' o mirar hacia la historia como una disciplina discursivamente superior, tiende a competir con ella o 
trata de usurparle un espacio desde donde hable una interpretación más profunda, matizada o severa que la de la historia misma” (pág. 76).

${ }^{16}$ Me parece importante el análisis que realiza Tulio Halperin Donghi de esta novela para demostrar que la experiencia histórica argentina es un efecto legado del terror, y advertir sobre el riesgo de buscar los aportes esenciales de esta experiencia en la etapa formativa de la Argentina moderna, pues implica alejar el terror hacia el pasado y metaforizarlo. ("El presente transforma el pasado: el impacto del reciente terror en la imagen de la historia argentina". En Ficción y política. La narrativa argentina durante el proceso militar. Buenos Aires, Alianza, 1987, págs. 71-95).

17 Opus cit., pág. 94.

18 Sugiero la lectura del ensayo "La Nueva Novela Histórica: La revolución es un sueño eterno" (En: Pilía de Assunçao, Nelda y Ravina, Aurora (ed.). Mayo de 1810. Entre la historia y la ficción discursiva. Buenos Aires, Biblos, 1999.)

19 Andrés Avellaneda menciona La revolución es un sueño eterno diciendo que "en novelas cuyo pasado es el siglo XIX, Rivera se refiere no obstante al presente: usa la historia ya remota para hablar de un presente tan cargado de horror y de enigma que se resiste a las formas del pacto mimético en sentido estricto". ("Lecturas de la historia y lecturas de la literatura en la narrativa argentina de la década del ochenta". En: Memoria colectiva y políticas de olvido. Opus cit., pág. 154).

${ }^{20}$ Me refiero a autores como Hayden White, cuyo pensamiento desarrollé en el primer capítulo, o Michel de Certeau en La escritura de la historia (1993) o La toma de la palabra y otros escritos políticos (1995).

${ }^{21}$ Ver Capítulo I.III.3. Testimonio y Autobiografía.

${ }^{22}$ Acerca de los alcances de estos conceptos, ver Capítulo I.

23 Sigo aquí la concepción de la autobiografía desarrollada por Philippe Lejeune, a la que me referí en el Capítulo I.

24 Molloy, Silvia. Acto de presencia. La escritura autobiográfica en hispanoamérica. México, Fondo de Cultura Económica, 1996, pág. 15. 
Capítulo VI

A modo de síntesis 
Las conclusiones que surgen de esta investigación no se limitan a agrupar los resultados alcanzados sino que pretenden explorar los límites que encuentra esta empresa.

En principio, es importante notar que la configuración del campo de investigación subrayó, sin duda, algunas cuestiones teóricas que me interesa recuperar aquí.

Por un lado, la relación testimonio-literatura que ha sido objeto central de crítica del testimonio se planteó como una problemática que se resuelve al considerar al testimonio como un discurso que interactúa con otros en el campo de los discursos sociales, para producir sentidos en el mundo de los lectores.

Por otro lado, el binomio testimonio-ficción es una discusión que operó sobre una delimitación de clase entre discurso ficcional y discurso factual, pero en este trabajo se sustenta sobre una diferencia de grado entre textos que dialogan en un campo de ficción, sin por ello perder su efecto político, ya que se establece una vinculación de la ficción con la acción a partir de la teoría del relato. Claro ejemplo de estos conceptos es la ficcionalización del relato testimonial por su ingreso a la novela.

Finalmente, la delimitación del testimonio con respecto a otros géneros, como la novela y la autobiografía, es un problema teórico, pero que alcanza su máxima expresión en la misma producción discursiva. De hecho, el análisis del corpus ha focalizado esta cuestión en las características propias del relato testimonial en la Argentina.

La Nueva Novela Histórica ocupa un lugar predominante en el campo literario de la Argentina de fin de siglo y la novela testimonial, como se ha demostrado, es una de sus modalidades.

Coincido con Bajtin cuando afirma que la novela es un género en proceso permanente de crecimiento y en el caso que nos ocupa, el discurso histórico y el periodístico le ofrecen materia para su revitalización, y los medios de comunicación crean su público. Consecuentemente, el lector puede observar cómo recupera desde lo intertextual e interdiscursivo a los testimonios, para ponerlos nuevamente en circulación desde la ficción. De este modo, la novela, al constituirse en un punto de tensión entre la literatura y la 
historia, pone en crisis a ambas, problematiza sus fronteras epistemológicas y abre un campo de recepción más amplio que difunde el saber. (Ver en el Anexo mi entrevista con John Beverly).

Si recordamos la relación que establece Foucault entre saber y poder podríamos decir que la Nueva Novela Histórica contribuye a una afirmación de la ciudadanía, tanto en su esencia conceptual como en el sentido de práctica concreta y cotidiana de los derechos civiles. He ahí su función política en este fin de siglo: es democratizadora de la sociedad. Sobre este punto, Rodolfo Rabanal ya anticipaba en un ensayo de 1992 ("La novela entre nosotros", en La escritura argentina, Santa Fe, Ed. Universidad Nacional del Litoral) que la ficción es un instrumento importante de democratización en la Argentina.

Sin embargo, me interesaría presentar una reflexión sobre este aspecto, un problema más que una respuesta. En primer lugar, creo importante destacar que el testimonio, en el sentido que le da John Beverly y la academia norteamericana en general, no se ha producido en la Argentina. Señalaré estos aspectos divergentes.

El testimonio es producido desde un sector letrado tanto en su expresión oral como escrita. Las voces del pueblo no han sido recuperadas, aún se mantienen en silencio. El registro más difundido, como el libro Nunca más, surgió como necesidad del campo jurídico y tuvo en él su sentido pragmático, por lo que recibió una fuerte influencia de grupos de poder político e intelectual.

El lugar de la enunciación es el de la clase media, no se trata pues de una subalternidad de clase sino política. Se trata de un sujeto políticamente desterritorializado por ausencia del cuerpo y de la voz, que ha perdido su condición de ciudadano e ingresa en la categoría de "desaparecido" y luego de "reaparecido" a través del relato. Lo que conduce a la formulación de una pregunta: ¿Cuál es la representatividad de este sujeto de enunciación? Los testimonios de "reaparecidos" producen un relato sobre la tortura y el dolor. Creo que para responder es importante detenerme en este tema, pues merece una revisión más profunda. 
La tortura es lo abyecto en el sentido kristeviano, pues suspende al sujeto y se instala al margen del derecho y de la ley, es inmoral. El relato se presenta como una necesidad de superar la abyección del dolor y del horror.

El dolor físico no tiene voz, pero cuando la encuentra comienza el relato sobre tres temas interdependientes: las dificultades para expresarlo, las complicaciones políticas y perceptuales que surgen de esas dificultades y la naturaleza de la creación humana. El dolor físico no sólo resiste el lenguaje sino que lo destruye, pues lo ubica en un estado anterior al lenguaje, de sonidos y llantos que el ser humano produce antes de aprender a hablar.

Elaine Scarry sostiene que la tortura se produce por la ocurrencia de tres fenómenos:

- el dolor es producido sobre una persona de diferentes maneras e intensidad.

- la amplificación del dolor tiene como objetivo hacerlo visible a aquellos que están fuera del cuerpo de la víctima.

- el dolor objetivado es negado como dolor y se lee como poder. Una traslación que se hace posible por mediación de agentes (técnicasacciones).

Así comprendida, la tortura tiene dos fases: infligir dolor es un acto físico y también verbal, por la interrogación. Asocia el cuerpo y la voz en una conexión interdependiente. Por lo tanto, la información es el motivo de la tortura, aunque esto es una ficción que tiene consecuencias sobre el sujeto y la valoración ética.

Para los torturadores la agonía humana se hace invisible y el efecto moral de la acción se neutraliza por la importancia de la interrogación. Para el prisionero, el dolor hace neutral el significado de las preguntas así como el mundo al que esas preguntas se refieren. El dolor intenso destruye el mundo propio (familia-amigos), se destruye el ser, la persona como sujeto. Quienes confiesan reciben el desdén, el desprecio de sus propios compañeros o familiares. Esto muestra cuán lejana es la experiencia del dolor físico y su realidad para quien no lo sufre como víctima.

Por otro lado, el acto verbal de la interrogación, tiene dos partes: la pregunta y la respuesta. La interpretación de estos actos produce dos errores 
que se instalan en una dimensión ética. El primero acredita al torturador, lo provee de una justificación: la crueldad tiene una explicación. El segundo desacredita al prisionero, haciéndolo responsable de la pérdida de su ser y su mundo. De tal forma, la pregunta es una absolución de la responsabilidad y la respuesta, por el contrario la confiere. Las dos juntas destruyen la realidad moral de la tortura. De esto se desprende que mientras el prisionero no tiene voz, su confesión se aproxima al silencio, al torturador. Se ubica en el discurso monológico, el prisionero está hablando con las palabras del régimen.

Estas consideraciones conllevan una conclusión: la traslación del cuerpo en voz es equivalente a la transformación del dolor en poder. Éste es el efecto político de la tortura. El dolor pertenece a la esfera privada, íntima. El cuerpo es el límite entre el adentro y el afuera, yo y el otro. La narración instala el dolor en la esfera pública del horror. Por lo tanto, nuestra experiencia del dolor y la violencia es primero estética más que real o moral. Podemos sustentar esta afirmación en la presencia del narrador testigo, que es lo que transforma el crimen en arte. La reacción del receptor será de extrañamiento y puede pasar por el horror, la admiración y el placer. En esta instancia se produce una estética del dolor y una erótica del dolor, respectivamente.

Para responder a la cuestión que dio origen a estas reflexiones, las particularidades del testimonio en la Argentina, retomaré el concepto de que es la narración la que ubica lo privado en lo público. El relato representa un sujeto cuya vivencia del dolor es individual. El riesgo de pensarlo como individual es que abre la posibilidad de que el otro es yo, no nosotros, y pierda así su carácter colectivo.

Sin embargo, la eficiencia del testimonio depende de su representación, y este relato es representativo en el horizonte de una lectura política: la violencia, la tortura y sus agentes involucran a 30.000 desaparecidos que no tienen cuerpo, sólo pueden ser representados por la voz del otro, "reaparecido".

La narración produce una estética que reclama la hermenéutica. La estética la ubica en el plano de la ficción y la hermenéutica debe instalar la cuestión en el plano político para restituir los vínculos entre estética y ética, y en el plano epistemológico para repensar la función de lo literario en el campo cultural argentino. 
Creo que la importancia de esta afirmación en el contexto de mi trabajo amerita que me detenga en algunas consideraciones que le permitirán al lector comprender mejor sus alcances.

En primer lugar, para despejar la relación entre estética y ética me parece pertinente desarrollar el pensamiento de Bajtin en una obra póstuma, La filosofía de la acción responsable, ${ }^{1}$ donde plantea el problema de apreciar el momento de la contingencia, el acto en su valor como evento único e irrepetible. Cuando desde un punto de vista estético se determina el sentido de dicho acto, éste pierde el carácter único y autosignificativo y asume un significado abstracto. De esta forma se crea una división entre mundo de la vida y mundo de la cultura, que implican una "responsabilidad moral y una responsabilidad especial”, respectivamente. Sólo la unidad de la responsabilidad puede integrar arte y vida. Ya en sus escritos de 1919 Bajtin afirmaba:

"El arte y la vida no son una cosa sola pero tienen que convertirse en una unidad en mí, en la unidad de mi responsabilidad". ${ }^{2}$

El nexo entre cultura y vida es pues la no-indiferencia, la acción responsable, que siempre está orientada por uno y hacia el otro. Si una acción pierde este sentido de la alteridad se transforma en una impostura.

Bajtin insiste en que es la literatura la que puede comprender estéticamente, llevando el objeto al plano valorativo del otro. Se trata de la relación autor-héroe en el ámbito textual, y de la complejidad del diálogo propio de los géneros secundarios como la novela. Sobre esta base se afirma la visión filosófica que el arte verbal hace posible.

Lo que me interesa subrayar es que Bajtin rechaza la idea de que la interpretación se reduzca a un simple encuentro entre dos conciencias, que anula la distancia para afirmar la comprensión. El sentido surge de la ubicación de los hechos en un contexto lejano, donde la identidad se abre a la alteridad.

Por su parte, Todorov, en un análisis de los campos totalitarios nazis titulado "Decir, juzgar, comprender", ${ }^{3}$ plantea que es la comprensión la que permite prevenir el retorno del horror, por eso no se debe encerrar un acontecimiento en su singularidad sino que se trata de ponerlo en relación con el presente y el futuro. No basta con decir el pasado, es necesario 
comprenderlo, pues afirma que "el combate no ha terminado. Se produce en otro lugar, en la memoria, en el juicio que hacemos sobre el pasado, en las lecciones que sacamos de él...". ${ }^{4}$

Es justamente la narración, más que el análisis conceptual, el que prueba la posibilidad de pensar y analizar que el pasado tenga sentido. Subrayar la categoría de sentido es focalizar un centro de interés: el sujeto, cuya esencia es el relato como "lugar de encuentro intersubjetivo".

En el relato es, entonces, donde se materializa la memoria, retrospectiva pero también recreadora y crítica, tanto que nos enfrenta a la cuestión de la identidad y de la memoria colectiva. Esta creación de la memoria conlleva la responsabilidad de recordar. El recuerdo no sólo recupera las huellas sino que incorpora la noción de duda, por la que filtra el futuro; no todo está dado y ha sido: aún queda lo por venir. El recuerdo del pasado y del futuro propicia los espacios de acción y decisión, introduce la densidad del juicio, reclama responsabilidad. Se trata de leer el pasado para intervenir y decidir, que forma parte del aprender.

Estas consideraciones derivan en lo que Ricoeur llama "política de la memoria", que abarca, por un lado, los usos de la memoria, y por otro, el olvido y el perdón. ${ }^{6}$

El ejercicio colectivo de la memoria, en ocasiones insuficiente y en otras excesivo, revela una crisis de la identidad colectiva, entre cuyas principales fuentes figura el lugar que la violencia tiene en su fundación. Sin duda, una mirada al proceso de la historia argentina nos pone frente a un léxico cuyos significantes son revolución, conquista, golpe militar, y todos ellos remiten a un sujeto común: el Estado. Dice Ricoeur: "Celebramos como acontecimientos fundadores esencialmente actos violentos legitimados más tarde por un Estado de derecho precario. De este modo se acumula en los archivos de la memoria colectiva un conjunto de heridas que no siempre son simbólicas." ${ }^{7}$ Como consecuencia, una relación verídica con el pasado, exige un trabajo de recuerdo (no de repetición) y de duelo (no melancolía), como ejercicio liberador.

Otra cuestión a considerar es que la política de la memoria elaborada por las clases dirigentes, orientada a construir identidades nacionales, operan 
una selección entre los hechos históricos, reteniendo aquellos funcionales a sus fines. Esta acción se apoya sobre el carácter selectivo de la memoria y nos pone frente al uso deliberado del olvido.

Ante los abusos de la memoria, la historia ejerce una función crítica a través de la selección de huellas, la explicación y la interpretación. En este sentido, la historia tiene que enfrentarse a la memoria oficial y a la identidad que ella justifica. El historiador tiene una responsabilidad ética: la de esclarecer no solamente la memoria hegemónica sino aquélla que decide y legitima la identidad colectiva. Se trata de partir del conocimiento de la pluralidad de las identidades para dar lugar a las memorias silenciadas.

El terror en nuestro país constituye un fenómeno muy complejo que reclama una historia capaz de recuperar aquello que tenga sentido para la sociedad. Para ello será necesario comprender que no hay sólo una memoria oficial y una memoria colectiva, sino que es necesario dejar hablar a la memoria dividida ${ }^{8}$, que pone al descubierto las fracturas que atraviesan a la sociedad.

He presentado hasta aquí la relación entre estética y ética que plantea la narración y más precisamente la novela testimonial, aunque se abren también al análisis otras cuestiones de orden epistemológico: las fronteras disciplinarias entre historia, literatura y periodismo; la complejidad del campo de ficción en el fin del milenio y el lugar de lo literario en el universo de discursos sociales.

En cuanto al primer aspecto enunciado, es necesario señalar que la relación entre relato y memoria que he desarrollado pone en evidencia los límites de la historia como disciplina, que implican la imposibilidad de un acercamiento interpretativo unilateral ante fenómenos tan complejos; el reconocimiento de que no toda historia y memoria son convergentes; la fragmentación de la memoria que da lugar a diversas narraciones; la coexistencia de narraciones hegemónicas "oficiales" junto a narraciones no convencionales; la redefinición de identidades, que más que integrarlas debe respetar las distintas memorias, sin por ello renunciar a ejercitar un juicio de valor sobre la evaluación del espacio de elección en la estructura militar de un estado totalitario, sobre la posibilidad de transformar la responsabilidad moral en responsabilidad penal. En suma, hacer justicia significa no sólo oponerse al 
olvido como dice Yerushalmi sino también atribuir responsabilidad como un acto ético. En esta división de tareas, la historia encuentra sus límites y sus puntos de contacto con la literatura y el periodismo.

En lo que respecta a éste último, recordemos que el campo periodístico no sólo interactúa con otros campos de producción cultural sino que ejerce coerción y, particularmente la televisión, tiene sus efectos sobre ellos.

El periodismo comparte con la historiografía el interés por la investigación y la descripción. Con la diferencia de que tiende a considerar que esta labor es esencialmente de denuncia. El problema es que a veces la denuncia puede contribuir a desviar la atención de los problemas estructurales que padece una sociedad a cuestiones particularizadas. El resultado es que corre el riesgo de ocultar, mostrando.

La historiografía debería, por otra parte, rescatar para su estudio aquellos temas que tienen significación social y darle nuevos sentidos a los hechos del pasado que la memoria colectiva necesita recuperar. El periodismo, en tanto, selecciona la información en función de los patrones que le impone la competencia con otros medios: lo sensacional y lo espectacular. Sin duda, éste es el efecto de la presión de fuerzas económicas que se materializa en el índice de audiencia.

Es importante destacar que para ambos hay una meta que orienta la labor y es la explicación; sin embargo, el periodismo no puede perder de vista una prioridad que es la exclusividad, para mantener la atención del público.

La eficacia de la televisión resulta de su poder para producir un efecto de realidad y sobre la realidad. De hecho, este poder de evocación puede provocar una elaboración social de la realidad, una movilización o desmovilización social y aún facilitar el acceso a la existencia política.

Uno de esos efectos, verdaderamente notable, es su influencia sobre el universo jurídico. Apoyado sobre la representatividad de la opinión pública, el periodismo induce la labor de la justicia, focalizando los problemas, y en algunas oportunidades transfiriendo el poder de juzgar.

Sin duda, el poder mediático sobre el campo de producciones culturales obedece a factores propios del microcosmos periodístico, pero también a su posición en un mundo global, en el que los otros campos, como el científico o el 
jurídico, han sufrido un desplazamiento. Este fenómeno entraña algunos riesgos, como el debilitamiento del campo político, un escepticismo respecto de su autoridad y función social, cuya consecuencia es la despolitización; una forma de "democracia directa" que genera una ciudadanía que ya no utiliza sus instituciones genuinas para comprender las leyes y ejercer sus derechos.

Los acontecimientos se vuelven inteligibles ubicándolos en el sistema de relaciones en el que se producen; sin embargo, la limitación del tiempo impone un discurso atomizado. La representación del mundo que ofrece la televisión no profundiza en los procesos, en el sentido histórico de los hechos, sino que resalta la instantaneidad y la discontinuidad. Estos peligros generan uno mayor, transformar a los medios de comunicación en un instrumento de opresión simbólica.

Para superar estas dificultades es necesaria una utilización democrática de los medios, lo que implica garantizar una distribución universal de saberes. Es decir, que la información llegue efectivamente a todo el mundo, para lo cual es necesario que se mantengan las condiciones de comunicatividad: una difusión más autónoma y un receptor educado para comprender la realidad desde su rol de ciudadano.

En nuestro país, han sido algunos medios de comunicación social y organizaciones no gubernamentales quienes han mantenido viva una memoria colectiva sobre la violencia de los setenta, que, en otros campos, como el político, el jurídico y aún el científico, se mantuvo silenciada. Algunos órganos escritos han sido constantes en su llamado de atención a la opinión pública; otros, como la televisión, si bien han respondido a la coerción del índice de audiencia buscando la novedad, han contribuido a instalar el problema en la sociedad. Su eficacia se hace notable por la interacción con el discurso histórico y literario; las investigaciones y la producción literaria retroalimentaron, amplificaron y aún profundizaron el tema.

Ante este estado del campo de producción cultural nos preguntamos cuál es la posición de los intelectuales en la Argentina de fin de siglo.

Raquel Angel anticipa una respuesta cuando habla de "el ocaso de intelectuales críticos y de la abulia que corroe a la cultura de estos años". ${ }^{9}$ 
Adriana Bergero profundiza la postura de Angel y sostiene que un amplio espectro de intelectuales de las redemocratizaciones neoliberales latinoamericanas son funcionarios subvencionados por universidades extranjeras. Dichos intelectuales desplazan o relegan la función crítica e interpretativa para ser "gestores del consenso-conformismo político, en donde lo político aparece únicamente restringido a los centros de poder burocrático y circunscripto a los intereses de las corporaciones". ${ }^{10}$

El planteo intelectual institucional tiene un tipo de continuidad en algunas publicaciones académicas. Causa extrañeza a un lector desprevenido el viraje de la propuesta de la revista Punto de Vista, especialmente notable en su número 58 , dedicado a la década del setenta. ${ }^{11}$ Sin embargo, observando su trayectoria se puede explicar esta transformación, pues si bien en su origen se la descubre como "la revista cultural más indicativa de un desafío directo al Proceso", con la transición democrática canalizó la expresión de una elite de intelectuales que abandonaron la resistencia para rearticularse en el programa hegemónico alfonsinista. ${ }^{12}$

Aunque Bourdieu define al intelectual como un personaje bidimensional que sólo existe por su autonomía y porque compromete esa autoridad específica en luchas políticas, ${ }^{13}$ en la Argentina asistimos a una especie de parálisis cultural en la que el intelectual ha cedido su lugar como poder de crítica y vigilancia y aún de propuesta. En este campo, también dominado por las reglas de la economía, la política y los medios de comunicación, son pocos los que persisten en sostener una práctica de la transgresión y menos aún los que están dispuestos a escucharlos. Recuperar ese lugar exigiría el compromiso colectivo de una nueva generación de intelectuales.

Si bien el mapa del terreno simbólico que focaliza una cuestión que Ricoeur llama "la memoria herida"14 es muy complejo, sin embargo me interesa detenerme ahora en un segundo aspecto a analizar: las condiciones de lo que he llamado campo de ficción, más amplio que el literario, por los alcances de la noción de ficcionalidad (ver Capítulo I).

Es inevitable observar el impacto de las nuevas formas audiovisuales sobre la cultura. En el paradigma de la información en el fin del milenio ha surgido una cultura de la virtualidad real ${ }^{15}$ que ha reemplazado los lugares por 
el espacio de los flujos, el tiempo por la atemporalidad, el signo por el simulacro. En esta cultura se produce una "narración simulada", cuyo recurso es la fragmentación y que no representa un mundo exterior sino que crea los acontecimientos y construye su propia referencia. Los valores de la sociedad se sustentan en la simultaneidad y la instantaneidad, se pierde toda visión histórica que contenga el pasado y el futuro. En este sistema simbólico no hay lugar para discusiones sobre la verdad o la realidad, pues disuelve la noción misma de representación. ${ }^{16}$

Este sentido de la historia crea una nueva estética y una nueva zona epistemológica. Así, asistimos a la coexistencia de lo audiovisual con el discurso literario y el histórico, en el campo de la ficción, en el que interactúan. Sin embargo, estos últimos se componen de una modalidad de relato cuya lógica narrativa emana de esa interacción discursiva, sin abandonar su configuración fundada en la trama. La narración así entendida se constituye en una manera de conocer el mundo y dar cuenta de la identidad del sujeto.

Se deduce fácilmente de esta descripción la complejidad del campo de ficción, aunque también puede identificarse una modalidad hegemónica: la narración, cuya expansión y diversificación reclama estudios que puedan enunciarse en lo que Raymond Williams llama "teoría cultural". ${ }^{17}$ Entiendo que esta perspectiva puede evitar un conocimiento reduccionista y desesperanzado que polarice el campo.

En síntesis, este espacio de tensiones entre literatura, historia, periodismo, que he tratado de describir brevemente, constituye el contexto de producción del relato testimonial y tiene consecuencias sobre la esfera epistemológica que, como se ha demostrado aquí, se manifiestan en la disolución de las fronteras disciplinarias; la configuración de un campo de discursos sociales del que forma parte el discurso literario; la necesidad de abordar estas problemáticas desde una reflexión teórica que exceda la especificidad para abarcar lo cultural; la creación de un público más heterogéneo que determine una distribución más amplia del saber.

Finalmente, la tercera cuestión que resulta central para esta investigación es la función de la literatura en el campo de producción cultural de la Argentina de fin de siglo, con especial atención al relato testimonial. 
La respuesta nos remite a una supervivencia del testimonio en la novela, y por lo tanto a un campo de circulación que abarca a una clase intelectual. No ha salido de la cultura letrada, y como consecuencia queda al margen una franja pública, sin voz (ver en el Anexo mi entrevista con John Beverly). El silencio es propio de las poblaciones más pequeñas y de la gente lejana a la metrópoli, tal el caso de Berisso, en la provincia de Buenos Aires, según me contara el investigador Daniel James. Su trabajo sobre historia oral le permitió entrevistar a más de 200 pobladores; sin embargo ninguno de ellos hizo referencia a ese período, habiendo sido Berisso una ciudad muy castigada por la dictadura militar (ver en el Anexo mi entrevista con Daniel James).

Por otra parte, la lectura se realiza en un contexto cuya característica destacable es el desgaste de la participación pública y la crisis de la representatividad política, lo que confirma un proceso de democratización de la sociedad aún sin concluir.

Esta apretada descripción contiene algunas afirmaciones pero también enuncia sus límites, pues si bien el proyecto narrativo de fin de siglo es poner en crisis el pasado, este propósito tiene algunos correlatos.

Se ha señalado insistentemente que es la interdiscursividad la condición que le da existencia al discurso social. En el caso del relato testimonial, en las circunstancias históricas y sociales que condicionan su producción y recepción, es posible reconocer un desplazamiento ${ }^{18}$ hacia otro tipo de discurso que aparece como una nueva forma pero se apoya en construcciones ya legitimadas. Me refiero a la Nueva Novela Histórica. Por consiguiente, la alternativa de supervivencia del relato testimonial con su finalidad política está dada por la presencia hegemónica de la Nueva Novela Histórica en el campo cultural de la Argentina de fin de siglo.

Por otro lado, el relato testimonial expresa una huella del pasado en la novela. Esto implica recordar que reclama una refiguración que contiene la impresión que los acontecimientos causaron sobre el sujeto receptor aún antes de que éste lo virtiera como testimonio, y luego en su dimensión discursiva los hechos se constituyen por las diferentes representaciones en distintas circunstancias históricas. El relato abarca esa temporalidad e inscribe en el cuerpo de la escritura la esperanza que renace de la resignificación constante. 
Por otra parte, esta incorporación del relato testimonial a la novela tiene otra implicancia: adhiere a la clave ficcional de la máscara que oculta y descubre. Entonces, el trabajo de lectura desmonta las verdades múltiples y quiebra el proyecto único de un autor para reconocer lo colectivo. Así, la novela testimonial es el lugar donde se atrinchera la identidad nacional acosada por lo transnacional. Consecuentemente, en la práctica hermenéutica se refuerza el efecto político de lo testimonial.

Cuando hablamos de política, hablamos de poder. La dimensión política del poder también opera sobre la memoria y sobre los "usos del olvido". De tal manera que la identidad colectiva se relaciona necesariamente con el poder que vincula el ser y el hacer. Se define no sólo por lo que es sino también por lo que hace.

En este caso, la ficción muestra una gestión del pasado que establece una política de la memoria, que retoma el efecto testimonial como efecto político y que vincula la estética con la ética.

Frente a este panorama, el relato testimonial encuentra una alternativa de supervivencia que puede constituirlo en una memoria justa del pasado: no olvidar para no repetir, no olvidar porque no es posible el perdón donde no hubo duelo, porque es la oportunidad de recordar la violencia con la esperanza de la no violencia; sin embargo, halla paradójicamente aquí su límite: que la violencia del Estado en los setenta sea leída como un momento más del proceso histórico de un país, y aún que se explique como consecuencia del gesto fundacional de la Nación. Esto entraña un riesgo, y es que el proyecto narrativo-estético del fin de siglo no sea eficaz en su dimensión ética. 


\section{Notas}

1 Se ha consultado Bajtin, Mijail. Hacia una filosofía del acto ético. De los borradores y otros escritos. Barcelona. Antropos, 1997, especialmente los comentarios de Augusto Ponzio.

2 Opus cit., pág. 227.

3 Todorov, Tzvetan. Frente al límite. México, Siglo XXI, 1993, págs. 258-288.

4 Opus cit., pág. 261.

${ }^{5}$ Manuel Cruz Rodríguez, en su obra Narratividad: la nueva síntesis, Madrid, Ediciones Península, 1990, sostiene que el sentido remite al sujeto porque designa el particular modo en que éste se relaciona con sus productos. La experiencia humana es una relación simbólica y el relato es el lugar de encuentro intersubjetivo. Le corresponde pues a cada individuo el diseño de esa superficie. Lo que en definitiva hace el sujeto es reescribir el texto heredado agregándole un personaje, él mismo. Por eso el relato es constitutivo de la esencia del sujeto, contar es una forma de empezar a ser.

${ }^{6}$ Ver Ricoeur, Paul. La lectura del tiempo pasado. Memoria y olvido. Madrid, Arrecife, 1999.

7 Opus cit., pág. 32.

8 Este concepto pertenece a Paolo Pezzino y fue presentado en una conferencia titulada "Juez e Historiador. La memoria dividida y la responsabilidad del historiador". (1997).

9 Para fundamentar esta tesis reúne trece entrevistas a intelectuales destacados. Recomiendo especialmente, por su pertinencia con el tema que nos ocupa, la lectura de las efectuadas a Ricardo Piglia, David Viñas, Osvaldo Bayer y José Pablo Feinmann. (Ver Angel, Raquel, opus cit.).

10 Bergero, Adriana. "Estrategias fatales e intrusos: discurso posmoderno y memoria implosiva en la Argentina de la redemocratización". (En Memoria colectiva y políticos del olvido, pág. 75).

11 Miguel Dalmaroni realiza un interesante análisis de los planteos de Oscar Terán y Beatriz Sarlo publicados en este número de la revista Punto de Vista. Señala algunas cuestiones polémicas que se leen en dichos artículos, como la impugnación del relato y la ficción como formas de conocimiento histórico; la separación entre política y cultura; la renuncia a la utopía moderna de reconectar arte y praxis política; la oposición entre políticas estéticas y políticas prosaicas. Véase: "El deseo, el relato, el juicio. Sobre el 'retorno a los setenta' en el debate crítico argentino 1996-1998" (En Tramas para leer la literatura argentina, Vol. V, № 9, 1998, págs. 35-42). 
12 Referencia tomada de Raquel Angel y de Osvaldo Bayer en Rebeldes $y$ domesticados, págs. 19 y 103.

13 Véase Pierre Bourdieu, opus cit., pág. 490.

14 Ricoeur, Pierre. Opus cit., pág. 31.

${ }^{15}$ Castells, Manuel. La era de la información. Economía, sociedad y cultura. Madrid, Alianza Editorial, 1997, Vol. 3, pág. 384.

16 Para profundizar esta nueva perspectiva frente a la representación sugiero la lectura del ensayo de Beatriz Sarlo "Aesthetics and post-politics: From Fujimori to the gulf war" (En Beverly, John y otros. The postmodernism debate in Latin América. Durham, Duke University Press, 1995, págs. 250-263).

17 Williams, Raymond. La política del modernismo contra los nuevos conformistas. Buenos Aires, Manantial, 1997, pág. 226.

18 Concepto de Marc Angenot desarrollado en un texto cuya traducción se encuentra en elaboración en la Universidad Nacional de Córdoba y que me facilitó la doctora Silvia Barei. 
Anexo

Visita a Duke University 
Mi visita a la Universidad de Duke tuvo como motivación inicial conocer el estado de la cuestión en cuanto al testimonio, dentro del campo de estudio del ámbito académico norteamericano. Había recibido noticias de que la última publicación sobre el tema provenía de Duke, y efectivamente me encontré allí con The Real Thing, obra que nuclea los trabajos de numerosos especialistas en el tema.

Fue Walter Mignolo, investigador argentino a cargo del Departamento "Romance Studies", quien hizo posible que tuviera acceso a todos los servicios de la Universidad y también quien me brindó posibilidades de conversar con los investigadores.

Mis actividades estuvieron orientadas a enriquecer un centro de interés: mi tesis sobre el testimonio. Con ese propósito asistí a la conferencia "Cross Genealogies", sobre subalternidad y estudios subalternos, evento en el que participaron, entre otros, John Beverly, George Yudice, Ernesto Laclau, Enrique Dussel, Javier Sanjinés, Iliana Rodríguez, John Kraniuskas.

Este fue el marco propicio para que pudiera conversar informalmente y concretar entrevistas posteriores con críticos e investigadores como John Beverly, Daniel James, Alberto Moreiras, Gabriela Nouzeilles. Por otra parte, la Universidad de Duke ofrece actividades académicas muy interesantes. Así es como participé de un seminario a cargo de Daniel James, titulado "Latin American Oral History", y en un coloquio coordinado por Alberto Moreiras. La dinámica de trabajo estuvo apoyada en el debate sobre temas propuestos por el coordinador y con el aporte de invitados especiales.

Uno de los encuentros a mi juicio más interesantes fue el destinado a reflexionar sobre los alcances de los "Estudios culturales", que contó con la disertación de Orin Starn, un antropólogo que planteó la permeabilidad de las fronteras interdisciplinarias en los estudios culturales. En el debate se formularon muchas preguntas acerca del lugar de la literatura, del texto y de los estudios literarios en un nuevo paradigma epistemológico.

Un servicio fundamental en Duke es la disponibilidad de información que se encuentra en dos bibliotecas (Perkins y Lilly) y en un sistema "interlibrary" que comunica con todos los servicios del país. Se completa con la Biblioteca de 
la Universidad de Chapell Hill, muy cercana y con una librería actualizada y ágil en la búsqueda de material ("Gothic").

Aunque es muy difícil transferir la riqueza de esta experiencia, me interesa compartir con los lectores de este trabajo los aspectos sustanciales de mi conversación con John Beverly, Daniel James, Gabriela Nouzeilles y Walter Mignolo, que he registrado en mis apuntes personales.

\section{Conversación con John Beverly}

John Beverly conocía el tema de mi tesis pues había establecido un contacto previo con él a través del correo electrónico y aceptó gentilmente este encuentro en Duke, el 16 de octubre de 1998.

JB: - ¿Cuál es el corpus de su trabajo sobre testimonio?

AG: -Abarca el campo de la literatura argentina contemporánea, en particular obras como las de Miguel Bonasso.

JB: -Su interés es el golpe de Estado.

AG: -Sí, la década del setenta y la represión.

JB: -El efecto del testimonio en la sociedad es muy importante. Las declaraciones de Scilingo provocaron una polémica, regresaron el tema.

AG: -Es muy fuerte el impacto de los medios de comunicación en la Argentina, su influencia sobre la opinión pública, la lectura y la escritura, especialmente de la televisión.

JB: -Se podría revisar la importancia de la televisión, pero no perder de vista que lo que nos interesa es el valor político del testimonio, el efecto del testimonio. 
¿Ha leído The real thing?

AG: -No, acabo de llegar y Walter Mignolo me lo regaló. Tenía referencias de su existencia, pero aún no he podido leerlo.

JB: -En el artículo que abre el libro trato de [exponer] mi posición, establecer la diferencia entre testimonio y literatura. Por eso disiento con Barbara Foley, porque con la noción de novela documental lo iguala a la novela, a la literatura.

AG: -Justamente mi investigación ha tomado como base teórica el concepto de que existe una diferencia de grado y no de clase entre el testimonio y la novela. Entiendo que subyace entre su postura y la de Foley una teoría del relato diferente.

JB: [Asintiendo con un gesto] -Yo creo que la ficción no abarca al testimonio. Si como plantea Foley fuera un tipo de novela, perdería su efecto, su función. Mi intención es preservar al testimonio como no literario, para que no pierda su valor [político].

Angel Rama, en "La ciudad letrada", habla de la preocupación de la literatura por convertirse en un sector de poder. Solo así el testimonio puede permanecer al margen de ese sistema [...].

Una escritora salvadoreña advierte que su obra no debe ser leída como literatura porque es testimonio.

Mis alumnos de Pittsburgh dicen que The Real Thing representa una clausura del debate sobre el testimonio.

AG: -Evidentemente hay diferencias sustanciales entre lo que usted plantea y el corpus de mi tesis.

JB: -En realidad en la Argentina no se está trabajando sobre problemas como el de la subalternidad, los estudios aún permanecen en la cultura letrada. Recientemente me encontré en Brasil con críticos argentinos y su posición 
está muy lejos de estas cuestiones. Es interesante que alguien se ocupe de salirse de la cultura letrada.

AG: -¿Cuál es su sugerencia?

JB: -Me preguntaría: ¿Cuál es la representación de la política que ha hecho la literatura?

AG: -Esa relación de literatura y política se remite al romanticismo.

JB: -No, la pregunta es cuál es la representación de la Nación que ha hecho la literatura argentina.

AG: -En el caso de mi tesis debería circunscribirla al relato testimonial, aunque lo he ubicado en el marco de la Nueva Novela Histórica (NNH).

JB: -Está bien considerarlo como NNH porque produce una crítica del pasado.

AG: -He considerado a la $\mathrm{NNH}$ como una manifestación del debate sobre posmodernidad.

JB: -Hay una preocupación por la posmodernidad pero creo que debemos salir del análisis de las novelas aisladas y quedarnos con una visión más global, una visión superior [del campo literario].

AG: -¿Preguntarnos por el lugar de la novela...?

JB: -La posmodernidad produce un desplazamiento de la novela y hay que analizar sus consecuencias. Jameson y Colas tienen un interesante ensayo sobre posmodernidad en la literatura argentina.

AG: -Una cuestión que plantea la Nueva Novela Histórica es la crisis de la historia. 
JB: -En realidad pone en crisis a ambas disciplinas. También la literatura está en peligro.

AG: -En cuanto al corpus, ¿qué me sugiere?

JB: -Se podrían incorporar otros textos, por ejemplo El infierno, de Arce, el testimonio de una autora chilena sobre la represión en Chile.

Y le reitero que es bueno que se interese por salir del canon de la cultura letrada.

\section{Conversación con Daniel James}

DJ: -¿Qué está trabajando del testimonio?

AG: -He leído parte de su investigación, el análisis del poema de Doña María, un capítulo de la investigación que realizó en Berisso sobre historia oral y periodismo.

DJ: -La verdad es que no sabía que hacer con él y entonces Alberto Moreiras me sugirió este método. El [centro] de mi investigación en Berisso es el peronismo en las historias orales.

AG: -Yo he abordado el tema [peronismo], pero desde la literatura en las novelas de Tomás Eloy Martínez.

El tema que investigo es la represión en la década del '70 y mi corpus está constituído por relatos testimoniales.

DJ: -¿El Nunca más?

AG: -Es para mí un referente, pero analizaré sobre todo José, de Matilde Herrera. 
DJ: -No lo conozco.

AG: -Se trata de un texto que no ha tenido circulación masiva. También trataré las novelas de Bonasso.

DJ: -¿Recuerdo de la muerte?

AG: -Sí, y La memoria en donde ardía. Aunque he estado estos días en la conferencia "Cross Genealogy" y veo que un tema que no he tenido en cuenta es el de la subalternidad.

DJ: -En los estudios subalternos existen dos líneas, una de orden histórico que mira el pasado para recuperar la voz de los que han sido marginados o silenciados. La otra es deconstructivista y posestructuralista: considera que el sujeto se construye en el otro. Se funda en la solidaridad como concepto central de su posición.

En esta línea puede consultar Spivak y Ghuha. Debe tratar de conseguir el artículo "Can the subultern speak?". ¿Leyó The Real Thing?

AG: -Sí, en parte.

DJ: -[...] Ésa es la diferencia entre Sommer y Moreiras. Tienen posiciones distintas frente al secreto, al límite que el sujeto [traductor] debe respetar. Moreiras está en la postura deconstructivista que sigue a Derrida.

El problema de la representación y de la intervención de un antropólogohistoriador que enciende la grabadora está [planteado] por Yudice y Colas.

(Me obsequia "Traslates women crossing the border with Esperanza's stry" de Behar)

Behar dice allí [señala el libro] que el traductor debe permanecer al margen y no es representativo de nadie. Creo que puede interesarte su libro. 
AG: -Pero para hablar de subalternidad en la Argentina debería construir la categoría del desaparecido como subalterno.

DJ: -Aquí, [refiriéndose a la academia norteamericana] la categoría de subalternidad está limitada sólo al indígena, al chicano, a Chiapas. No se ha trabajado sobre "desaparecidos" por ejemplo. Pero creo que sería interesante construir la subalternidad para el Cono Sur.

AG: -Como subalternidad política.

DJ: -Sí, podría consultar Lejeune, su ensayo J'ai un autre.

La Fundación Rockefeller está muy interesada en la represión y los gobiernos militares en el Cono Sur. Hay una beca muy importante para investigadores.

AG: -¿Sería posible preguntarse acerca de la representación de la Nación que produce la literatura?

DJ: -El concepto de Nación es inabarcable, es parcial [está dado] desde la literatura del centro porque deja afuera casos locales como por ejemplo el de Berisso. Es importante ver cómo opera la memoria colectiva para decir o para silenciar. Berisso es una comunidad que no habla del tema, hubo jóvenes desaparecidos, casi toda una división de $5^{\circ}$ año de los estudios de nivel medio.

En casi 200 entrevistas que realizamos para la investigación nunca apareció el tema, nadie lo mencionó. Transcurrieron cinco años después de la vuelta de la democracia y en 1988 se movilizaron, pusieron unas placas por los desaparecidos y Osvaldo Bayer visitó el lugar, hizo un discurso, la gente se reunió...

Hay un libro de Connerton, How societies remember?, que muestra cómo la memoria colectiva se manifiesta no sólo desde el lenguaje [...]. 
AG: -En la Argentina tienen un papel muy importante los medios de comunicación. Por ejemplo, el diario Página/12 ha tenido gran protagonismo en la recuperación del pasado. Por eso planteo en mi investigación una estrecha relación entre literatura y periodismo.

DJ: -Sí, pero también hay que tener mucho cuidado con lo que se publica. Hace unos años fue a Berisso una periodista del diario Página/12 y entrevistó a cuatro ancianos. Los llevó a recorrer la ciudad para que recordaran y reconstruyeran cómo se había vivido allí la llamada Revolución Libertadora, en 1955. El diario publicó la historia como testimonial y verdadera. Pero la gente que los conocía comentaba que algunos ni siquiera habían estado allí en esa época. Cuando se les preguntó por qué se habían prestado... [se encoge de hombros], creo que no le dan la importancia que tiene, buscaban protagonismo, tenía para ellos cierta diversión.

AG: -El presupuesto teórico que define a los textos que constituyen el corpus como testimoniales es que establecen relaciones interdiscursivas con otros que provienen de la historia. ¿Qué textos me recomendaría leer con este propósito?

DJ: -Bueno, [...] Nunca más, y no sé si conoce La Voluntad, ya hay un segundo tomo. Tome algunas partes, es un libro muy extenso [...].

AG: -Sí, está previsto en mi investigación. También he leído un artículo de Beatriz Sarlo publicado en la revista Punto de Vista. Dice Sarlo que existe cierta nostalgia por el pasado en los autores.

DJ: -En realidad creo que es Sarlo quien se ha quedado en el pasado, es en ella que hay una nostalgia, pero por una Argentina anterior a los sesenta.

Al despedirnos, James me dio muy gentilmente algunos trabajos para que profundizara sobre el tema subalternidad y me recomendó que 
entrevistase a Alberto Moreiras, con quien finalmente no pude concretar una entrevista personal por sus ocupaciones, pero sí asistí a un coloquio que coordinaba sobre Estudios Culturales Latinoamericanos.

\section{Conversación con Gabriela Nouzeilles}

AG: -Después de la conferencia me preocupa explorar sobre estudios culturales.

GN: -En la librería "Gothic" encontrarás una recopilación de Grossberg sobre "Cultural Studies". Allí están los [ensayos] más importantes y podés tener una visión general. De todas maneras creo que tu tema está en el marco de la non-fiction de Truman Capote.

AG: -Me he centrado más en la novela testimonial. Sólo como referente del testimonio he tomado Nunca más.

GN: -En ese caso es importante preguntarse quién escribe porque hay primero un relato oral que después se transforma en escrito. Allí hay que detenerse en la historia oral.

AG: -A partir de esta diferencia de grado, también pensé en algún momento en incorporar a Luisa Valenzuela, Novela negra con argentinos, por ejemplo.

GN: -Podría servir como contraste, para ver la diferencia con lo vendible, mostrar que la cultura se exporta...

AG: -Los medios intervienen...

GN: -Sí, pero también sufren la absorción por el mercado. El diario Página/12, [que se apoya] sobre su actividad subversiva. (sic) 
Creo que es importante encontrar conexiones entre los textos, plantear las preguntas y ver si funcionan o no.

Una posibilidad es ver la tortura como lectura y como escritura. Hay un libro, creo que podés encontrarlo en la biblioteca Perkins, que es clave: The esthetics of murder. Puede servirte como modelo, para que veas como analizar una obra, para que observes el método de trabajo.

Fijate en la "Gothic", podés conseguir un libro de Scarry, The body in pain, aquí aparece una estética de la violencia.

Como una [cuestión] práctica es aconsejable consultar una bibliografía general, sobre otras cosas, pero que sirve como modelo.

AG: -Mi hipótesis o mi pregunta a los textos es ¿Cómo representan la sociedad del los setenta?

GN: -También podés preguntarte sobre la recepción; cómo funciona en cada uno el pacto [de lectura].

¿Cómo se representa la violencia? sería una pregunta posible. Podés ver otros géneros, el cine, los graffitis por ejemplo.

AG: - Voy a analizar también José, de Matilde Herrera

GN: -No lo conozco.

AG: -[...] Plantea un problema de género, es testimonial, pero podría ser leído como autobiográfico también.

GN: -En ese caso podés tomar algunas ideas de un trabajo de Jean Franco que se llama algo así como "El Diario de Guevara".

También podés ver la diferencia entre la autobiografía pública y la autobiografía política en América Latina y EE.UU. para luego llevarla a la Argentina. Hay una tesis que se llama el "Acto autobiográfico" creo. (Localicé luego el material en la Biblioteca de la Universidad de Chapell Hill). 
GN: -Una estética de la violencia puede neutralizar el objetivo del testimonio y [en casos extremos] transformarse en pornografía.

AG: -Creo que en la novela de Liliana Heker, El fin de la historia, se produce una erótica de la violencia, casi como un recurso principal que traduce una ideología acerca de la represión.

\section{[En un segundo encuentro con Gabriela Nouzeilles]}

GN: - ¿Encontraste la bibliografía?

AG: -Sí, casi todo.

GN: -Pensé después que podrías abrir un campo de comparación con el cine e incluso con la pintura. Hay pintores que han recuperado la época como una estética del horror, presentando lo feo porque no se puede estetizar el dolor en el sentido tradicional. El cuerpo, el dolor, la muerte. generan otra estética que escapa a la tradicional, relacionada con lo bello.

Yo podría vincularte con un pintor que hace poco expuso en el Museo de Bellas Artes. Tengo amigos que podrían ayudarte a buscar.

En el cine hay también un relato de la época. Tendrías que ver cómo es. Remitirte al cine documental, no comercializado.

AG: -¿Es hacer "Cultural Studies"?

GN: -[Asiente con un gesto] La idea es no quedarse en la teoría porque no está al alcance de todos, sino llevar el estudio al plano pragmático, hacer un estudio de campo.

AG: -En mi experiencia la teoría ha ocupado mucho espacio. 
GN: -Sí, entiendo, porque parece que eso le da rigurosidad al trabajo. Es una costumbre de los medios académicos argentinos. Pero la teoría está allí y no es necesario explicitarla, sí hablar de lo que uno lee y en esto es importante leer otros libros para observar estrategias. La originalidad no está en inventar o aplicar una teoría sino en inspirarse en algo que sugiere ideas nuevas.

GN: -[...] Revisar el rol de la mujer que toma un arma pero que también debe lavar los platos [...]. Mujeres guerrilleras, de Marta Diana (Editorial Planeta, 1997), muestra justamente esa dicotomía de la mujer. Aquí en EE.UU. se trabaja mucho sobre cuestiones de género.

AG: -¿Cómo puedo localizar el material?

GN: -En "Gothic", en la sección "Women Studies".

\section{Conversación con Walter Mignolo}

AG: -Quería agradecerle su colaboración y especialmente el libro The Real Thing, aunque debo confesarle que hacía un año que estaba tratando de localizarlo y usted me lo dio en mi primer día aquí, así que pensé que ya podía regresar...

WM: -[Se ríe] Cuénteme sobre su investigación.

AG: -[Hago una reseña de los materiales, obras a analizar y elementos teóricos]

WM: -[El corpus] parece coherente, pero para qué. 
AG: -Para responder a cómo representan la década del setenta; cómo y por qué circulan hoy estos textos; qué representan para la sociedad hoy.

WN: -¿Y cuál es su tesis?

AG: -Que esas obras representan una ampliación del campo literario y producen un efecto ético y estético.

WM: -[Asiente]... y epistemológico, porque se masifica el conocimiento.

AG: -Estas novelas (Recuerdo de la muerte y El fin de la historia) pueden considerarse como Nueva Novela Histórica, por sus características.

WM: -Las diferencias entre Nueva Novela Histórica y testimonio deben especificarse claramente. Estas novelas representan el pasado pero con un significado para el presente [...] ¿No ha pensado en [trabajar también sobre] la literatura latinoamericana?

AG: -He recibido sí algunas sugerencias.

WM: -En Colombia, por ejemplo, no se han ocupado del testimonio; en Bogotá, donde estuve la semana anterior, no hay investigaciones sobre testimonio de la violencia. 
* Bibliografía

MASIELLO, Francis. "Cuerpo/presencia: mujer y estado social en la narrativa Argentina durante el proceso militar". En Nuevo texto crítico. № 4 (Año II) Segundo semestre, 1989, págs. 155-171.

ROSSI, Laura. “¿Cómo pensar a las Madres de Plaza de Mayo?”. En Nuevo texto crítico $\mathrm{N}^{\circ} 4$ (Año II) Segundo semestre, 1989, págs. 145-153.

DALMARONI, Miguel. "El deseo, el relato, el juicio. Sobre el 'retorno a los setenta' en el debate crítico argentino, 1996 - 1998". En Tramas para leer la literatura argentina. Vol. V, № 9, 1988, págs. 35-45

ECO, Umberto. Obra abierta.. Barcelona, Ariel, 1985.

Lector in fábula, La cooperación interpretativa en el texto narrativo. Barcelona, Lumen, 1987.

TODOROV, Tzvetan. Frente al límite. México, Siglo XXI Editores, 1993.

BOURDIEU, Pierre. Las reglas del arte. Génesis y estructura del campo literario. Barcelona, Anagrama, 1995.

Sobre la televisión. Barcelona, Anagrama, 1996.

SOSNOWSKI, Saúl (comp.) Represión y reconstrucción de una cultura: el caso argentino. Buenos Aires, Eudeba, 1988.

GARDES, Roxana. La recepción de la narrativa (De los modelos lecturales a una tipología) Buenos Aires, Editorial Vinciguerra, 1992.

FEINMANN, José Pablo. La sangre derramada. Ensayo sobre la violencia política. Buenos Aires, Ariel, 1998.

BERGERO, Adriana y REATI, Fernando (comp). Memoria colectiva y políticas de olvido. Rosario, Beatriz Viterbo Editora, 1997.

ACHUGAR, Hugo (comp.). En otras palabras, otras historias. Uruguay, Universidad de la República.

AMAR SANCHEZ, Ana María. "La ficción del testimonio". Revista Iberoamericana № 56, 1990

El relato de los hechos. Rodolfo Walsh:Testimonio y escritura. Rosario, Beatriz Viterbo, 1992.

ANGEL, Raquel. Rebeldes y domesticados; los intelectuales frente al poder. Buenos Aires, El cielo por asalto, 1992. 
BAJTIN, Mijail. Épica y Novela. Acerca de la metodología del análisis novelístico.

BALDERSTON, Daniel y otros. Ficción y política; la narrativa argentina durante el proceso militar. Buenos Aires, Alianza, 1987.

BARNET, Miguel. "Testimonio y comunicación”. (En Literatura y Testimonio, Minnessotta, Jara Vidal, 1984).

BAYER, Osvaldo. Rebeldía y esperanza. Buenos Aires, Zeta, 1993.

BESSIÈRE, Jean. “Literatura y representación” (en Teoría literaria. Buenos Aires, Siglo XXI, 1993)

BEVERLY, John y otros. The Postmodernism Debate in Latin America. Durham, Duke University Press, 1995

"¿Posliteratura? Sujeto subalterno e impasse de las humanidades”. (En Casa de las Américas, año XXXIII, º 190, enero - marzo 1993.

BLACK, Joel. The Aesthetics of Murder. A study in Romantic Literature and Contemporary Culture. London, John Hopkins University Press, 1989.

BOURDIEU, Pierre. Campo del poder y campo intelectual. Folios Ediciones Campo intelectual y proyecto creador. Buenos Aires, Gráfica Panamericana, 1962.

CARAVALLO y otros. La dictadura 1976 - 1983. Buenos Aires, UBA, 1996.

CASAUS, Víctor. "Defensa del testimonio". (En Literatura y Testimonio, Minnessotta, Jara Vidal, 1984).

CAVALLERI, H. "Ficción, testimonio y representación”. (En Literatura y Testimonio. Minnessotta, Jara Vidal, 1984).

COLAS, Santiago. Postmodernity in Latin America. The Argentine Paradigm. Durham, Duke University Press, 1994.

CONNERTON, Paul. How Societies Remember. Cambridge, University Press, 1996.

CROSS (¿¿??) Genealogies and Subaltern Knowledges Conference. October 15 - 18, 1998. Romance Studies Department, Duke University, Durham (Reader).

CULLER, Jonathan. "La literariedad". ( En Teoría Literaria.Buenos Aires, Siglo XXI,1993.)

DOLEZEL, Lumezil. Mimesis as Possibles Worlds. (En Poetics Today 9:3) 
DOMINGUEZ, Mignon (Coord.) Historia, ficción y metaficción en la novela latinoamericana contemporánea. Buenos Aires, Corregidor, 1996.

EAGLETON, Terry. The Ideology of the Aesthetic. Oxford, Blackwell Publishers, 1997.

FOLEY, Barbara. Telling the Truth. London, Cornell University Press, 1986.

FOSTER, David W. Violence in Argentine. Cultural Responses to Tyrany. Columbia, University of Missouri Press, 1995.

GLOWINSKI, Michel. "Document as Novel”. (En Literatura y Testimonio, Minnessotta, Jara Vidal, 1984).

GUGELBERGER, Georg. (ed.) The Real Thing. Durham, Duke University Press, 1996.

HALPERIN, Jorge. Pensar el mundo. Conversaciones con las personalidades más lúcidas de fin de siglo. Buenos Aires, Planeta, 1997.

HAMBURGUER, Käte. La lógica de la literatura. Buenos Aires, Visor, 1995.

HUTCHEON, Linda. The Politics of Postmodernism. London, Routledge, 1995.

JAMESON, Fredric. The Cultural Turn: selected writings on the postmodern 1983 - 1998. London, Verso, 1998.

The Political Unconsciours. Narrative as a socially simbolic act. New York, Cornell University Press, 1981.

JARA, René. "Testimonio y literatura". (En Literatura y Testimonio, Minnessotta, Jara Vidal, 1984).

JAUSS, Hans. La literatura como provocación. Barcelona, Península, 1976.

JITRIK, Noé. Historia e imaginación literaria. Buenos Aires, Biblos, 1996.

KERMODE, Frank. El sentido de un final. Barcelona, Gedisa, 1983.

KOHUT, Karl. . Literatura argentina hoy. De la Dictadura a la Democracia. Frankfurt, Vervuert, 1993.

Literatura del Río de La Plata. De las utopías al desencanto. Frankfurt, Vervuert, 1993.

KRISTEVA, Julia. Pouvoirs de I'horreur. Essai sur l'abjection. Paris, Senil, 1980

LEJEUNE, Philippe. Je est un autre. L'autobiographie de la Litterature aux médias. Paris, Senil, 1976. 
LUDMER, Josefina. Las culturas de fin de siglo en América Latina. Rosario, Beatriz Viterbo, 1994.

MACHIN, Horacio. "Conversación con Frederic Jameson". (En Nuevo Texto Crítico. Año IX, $1^{\circ}$ semestre 1991, $\mathrm{n}^{\circ} 7$ ).

MIGNOLO, Walter. "Semantización de la ficción literaria". (Dispositio, Vol V-VI. Department of Romance Languages, University of Michigan).

Teoría del texto e interpretación de textos. México, UNAM, 1984

El metatexto historiográfico y la historiografía indiana. (Mun vol. 96 p. 358-402)

"Los estudios subalternos ¿son posmodernos o poscoloniales?. La política y las sensibilidades de las ubicaciones geoculturales". (Casa de las Américas, Vol. 37, n²04, 1996).

MORAÑA, Mabel. "Documentalismo y ficción: testimonio y narrativa testimonial hispanoamericana en el siglo XX". (En América Latina: Palabra, Literatura y Cultura. Vol 3. Editora Unicamp, 1995.)

MOREIRAS, Alberto. "Transculturación y pérdida del sentido.El diseño de la postmodernidad en América Latina”. (En Nuevo Texto Crítico. Año III, $2^{\circ}$ semestre de 1990, $\mathrm{n}^{\circ} 6$ ).

NEWMAN, Kathleen. La violencia del discurso. El estado autoritario y la novela política argentina. Buenos Aires, Catálogos, 1991.

NORA, Pierre. Les lieux de memoire. Paris, Gallimard, 1987.

NUEVO TEXTO CRITICO. Año VI. Julio 1993 - junio 1994. Nº 12 - 13. (Número dedicado a Rodolfo Walsh).

OHMAN, Richard. "Politics and Genre in No-Fiction Prose". V de California.

PERUS, Francoise. Historia y literatura. México, Instituto Mora, 1994.

PRADO OROPEZA, R. "De lo testimonial al testimonio". (En Literatura y Testimonio. Minnessotta, Jara Vidal, 1984).

RAMA, Angel y otros. Conversación en torno al testimonio. (En Casa de las Américas, vol. 36, $\left.\mathrm{n}^{\circ} 200,1995\right)$.

RANDALL, M(¿¿??). ¿Qué es y cómo se hace un testimonio?. Univ. de N. México, 1986.

REVISTA de Crítica Literaria latinoamericana_Año XVIII, nº 36, 1992.

RICOEUR, Paul. Tiempo y narración. Configuración del tiempo en el relato de ficción._Madrid, S XX, 1995. (Tomo II). 
Texto, testimonio y narración. Chile, Ed. Andrés Bello, 1983.

RIVERO, Eliana. "Acerca del género Testimonio: textos, narradores y artefactos". (En Hispanoamérica, vol. 16, n 46 - 47, 1987).

ROSSI, Laura. “¿Cómo pensar a las Madres de Plaza de Mayo?” (En Nuevo Texto Crítico, $n^{\circ} 4$ (año II) ,1989).

SARLO, Beatriz. "Cuando la política era joven". (En Punto de Vista N 58 ). "¿Arcaicos o marginales? Situación de los intelectuales en el fin de siglo". Punto de Vista, N 47, 1993.

SCARRY, Elaine. The body in pain. The making and unmaking of the world. New York, Oxford University Press, 1985.

SKLODOWSKA, Elzbieta. Testimonio hispanoamericano, historia, teoría, poética. New York, Lang, 1991.

SPIVAK, Gayatri. "Can the Subaltern Speak?" (En Colonial Discourse and Postcolonial Theory. New York, Columbia University Press, 1994.

"Three Women's Texts and a Critique of Imperialism". (Critical Inquiry, $\mathrm{n}^{\circ} 1$, vol. 12,1985). 44.

"Echo". New Literary History. Vol 24, n 1, Winter 1993. Págs. 17-

TAYLOR, Diana. Disappearing Acts. Spectacles of Gender and Nationalism in Argentina's Dirty War. Durham, Duke University Press, 1997.

TERAN, Oscar. "Pensar el pasado". (En Punto de Vista, N 58).

TIZON, Héctor; RABANAL, Rodolfo; GRAMUGLIO, Teresa. La escritura argentina. Rosario, Universidad Nacional del Litoral, 1992.

ULANOVSKY, Carlos. Paren las rotativas. Historia de los grandes diarios, revistas y periódicos argentinos. Buenos Aires, Espasa Calpe, 1997.

WHITE, Hayden. El contenido de la forma narrativa, discurso y representación histórica. Buenos Aires, Paidós, 1992.

YERUSHALMI, J(¿¿??). Los usos del olvido. Nueva Visión, 1987.

YUDICE, George. "El conflicto de posmodernidades". (En Nuevo Texto Crítico, año IV, $1^{\circ}$ semestre $\left.1991, N^{\circ} 7\right)$.

"Posmodernism in the Periphery". (En The South Atlantic Anarlerty, Vol. 92, N³, 1993).

ANGUITA, Eduardo y CAPARRÓS, Martín. La Voluntad (Tomo I, II y III). Buenos 
Aires, Grupo Editorial Norma, 1997 - 1998.

BONASSO, Miguel. Recuerdo de la muerte. Buenos Aires, Planeta, 1994. La memoria en donde ardía. Navarra, Txalaparta, 1992.

CONNERTON, Paul. How Societies Remember. Cambridge University Press, 1998.

CURRIE, Mark. (ed). Metaficción. London, Longman, 1995.

DRUCAROFF, Elsa. Fue por algo. Análisis del prólogo a Nunca más, informe de la CONADEP. (En Nuevos Territorios de la Literatura Latinoamericana. Buenos Aires, UBA, 1997).

FOSTER, David Williams. Violence in Argentine Literature. Cultural response to tyranny. London, University of Missouri Press, 1995.

KERBRAT, Orecchione (¿¿??). La enunciación. Buenos Aires, Paidós, 1992.

LEJEUNE, Philippe. Je est un autre. L' autobiographie de la Littérature aux médias. París, Senil, 1975.

MIGNOLO, Walter. "Entre el canon y el corpus. Alternativas para los estudios literarios y culturales en y sobre América Latina". (En Nuevo Texto Crítico, vol. $7, n^{\circ} 14$ - 15, julio 1994 - junio 1995).

O'DONNELL, Guillermo. Contrapuntos. Ensayos escogidos sobre autoritarismo y democratización. Buenos Aires, Paidós, 1997.

PARDO, María Laura.

Cap. 3. La gestación del texto.

Cap. 5. Las categorías semánticas: remáticas-nexos de valor.

Cap. 6. Las categorías semánticas: remáticas, Tema del texto y Rema del texto. (Mimeografiado)

PIGLIA, Ricardo. Plata quemada. Buenos Aires, Planeta, 1998.

TAYLOR, Diana. Disappearing Acts. Durham, Duke University, 1997.

VAN DIJK, Teun. Racismo y análisis crítico de los medios. Barcelona, Paidós, 1997.

WALSH, Rodolfo. Carta abierta de un escritor a la Junta Militar. Buenos Aires, Colihue, s. f.. 